Andrews University

Digital Commons @ Andrews University

Professional Dissertations DMin

Graduate Research

2005

\title{
A Discipleship Model for Evangelism in Northeast Brazil
}

Emilio Abdala Dutra

Andrews University

Follow this and additional works at: https://digitalcommons.andrews.edu/dmin

Part of the Practical Theology Commons

\section{Recommended Citation}

Dutra, Emilio Abdala, "A Discipleship Model for Evangelism in Northeast Brazil" (2005). Professional Dissertations DMin. 467.

https://dx.doi.org/10.32597/dmin/467

https://digitalcommons.andrews.edu/dmin/467

This Project Report is brought to you for free and open access by the Graduate Research at Digital Commons @ Andrews University. It has been accepted for inclusion in Professional Dissertations DMin by an authorized administrator of Digital Commons @ Andrews University. For more information, please contact repository@andrews.edu. 
ABSTRACT

\section{A DISCIPLESHIP MODEL FOR EVANGELISM \\ IN NORTHEAST BRAZIL}

by

Emilio Abdala Dutra

Adviser: Ricardo Norton 


\title{
ABSTRACT OF THE GRADUATE STUDENT RESEARCH
}

\author{
Dissertation
}

\author{
Andrews University
}

Seventh-day Adventist Theological Seminary

Title: A DISCIPLESHIP MODEL FOR EVANGELISM IN NORTHEAST BRAZIL Name of researcher: Emilio Abdala Dutra

Name and degree of faculty adviser: Ricardo Norton, D.Min.

Date completed: April 2005

\section{Problem}

Churches in Northeast Brazil (NB), including the Seventh-day Adventist Church, have been growing rapidly. Their numerical growth is phenomenal by any estimation. However, these churches are growing numerically and not in depth. We see a discipleship deficit among new believers in the form of a high rate of backdoor losses, unawareness of the meaning and duties of discipleship, spiritually undisciplined members, absence of intentional relationships to share faith, biblical illiteracy, and lack of church fellowship. How can churches in Northeast Brazil grow in quality, reproducing fully devoted followers of Jesus Christ? 


\section{Method}

Current literature related to the problem was reviewed, including books and articles on the principles, strategies, and programs to enrich my notion of discipleship in the context of evangelization. Factors responsible for the superficial discipleship that has contributed to the loss of new members in Teresina-one of the principal cities of Northeast Brazil-were also investigated.

Personal and corporate models of discipleship were examined in order to create a holistic scheme that provides an integrative strategy of the various components of evangelism toward the end of making disciples for the NB territory.

\section{Conclusion}

Christian churches lose ground because they lack plans for developing spiritual maturity in the lives of believers. A mature believer is one who is growing in his/her love for Christ, is growing in his/her love for other believers, and is growing in his/her ability to reach the world. Jesus' ministry and teachings put spiritual maturity at the heart of the gospel's mandate (Matt 28:19, 20).

As a result of this research, a discipleship model was created to help new converts become responsible members. This model suggests an intentional strategy for shaping and molding the lives of believers into the image of Jesus Chris. The model consists of a simple organizational structure that encourages and enables ministry to occur, and emphasizes spiritual multiplication through training. The model releases people into ministry according to their spiritual gifts. 
Andrews University

Seventh-day Adventist Theological Seminary

\title{
A DISCIPLESHIP MODEL FOR EVANGELISM \\ IN NORTHEAST BRAZIL
}

\author{
A Dissertation \\ Presented in Partial Fulfillment \\ of the Requirements for the Degree \\ Doctor in Ministry
}

by

Emilio Abdala Dutra

April 2005 


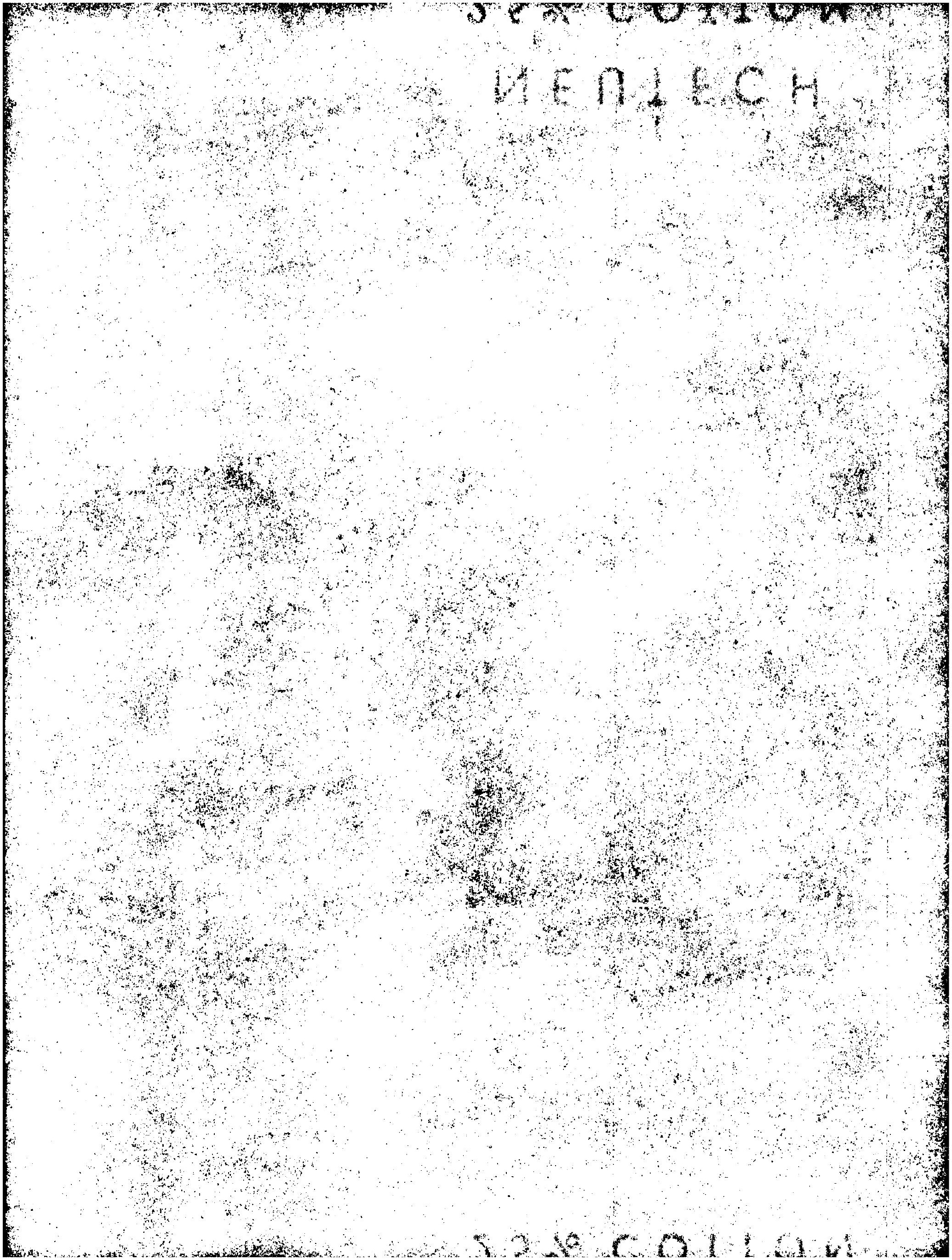




\title{
A DISCIPLESHIP MODEL FOR EVANGELISM IN NORTHEAST BRAZIL
}

\author{
A dissertation \\ presented in partial fulfillment \\ of the requirements for the degree \\ Doctor in Ministry
}

by

Emilio Abdala Dutra

APPROVAL BY THE COMMITTEE:

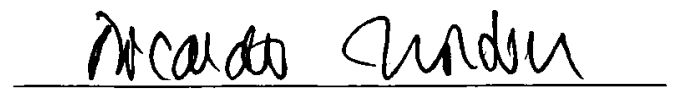

Adviser

Ricardo Norton

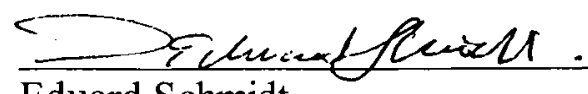

Eduard Schmidt

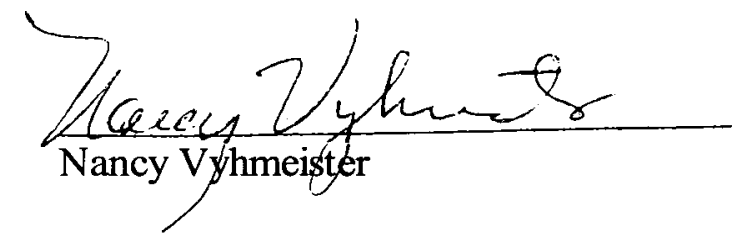

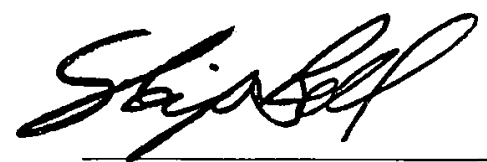

Director of D. Min. Program

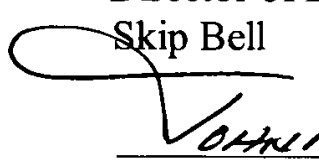

Dean, SDA Theologicat Seminary John McVay

April 20, 2005 Date approved 


\section{TABLE OF CONTENTS}

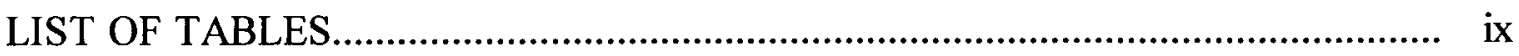

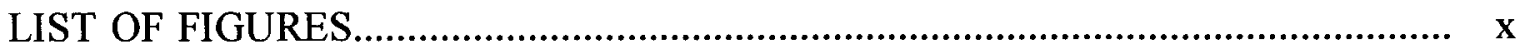

ACKNOWLEDGMENTS................................................................................ xi

Chapter

I. INTRODUCTION

Statement of the Problem................................................................................ 1

Statement of the Task..................................................................................... 2

Justification for the Dissertation................................................................ 2

Definition of Terms............................................................................... 3

Delimitations of the Dissertation................................................................ 5

Description of the Dissertation Process........................................................ 5

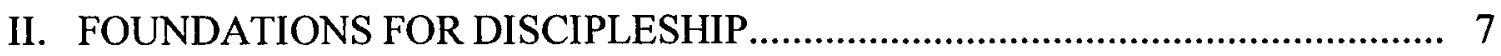

The Great Commission.................................................................... 7

Definitions.................................................................................... 10

Disciple

Discipling and Discipleship............................................................... 14

Jesus' Discipleship Model.......................................................................... 16

The Seeker/Selection Phase............................................................. 17

The Life Transference Phase................................................................. 20

The Instruction Phase.................................................................... 22

The Deployment Phase................................................................ 25

The Reproduction Phase...................................................................... 27

Paul's Discipleship Model...................................................................... 29

Patterns in Paul's Missionary Journey................................................. 29

Conversion and Church Planting.................................................... 30

Recruitment and Organization...................................................... 31 
Nurture and Relationships.......................................................... 31

Apprenticeship and Reproduction................................................... 32

Paul's Personal Model......................................................................... 34

Demonstration......................................................................... 34

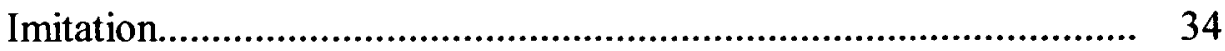

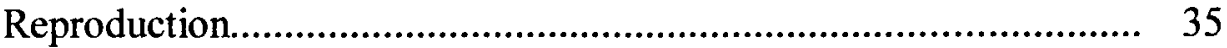

Paul's Corporate Model..................................................................... 36

The Ephesian Church Strategy......................................................... 36

The Ephesian Discipling Ministry................................................... 38

The Ephesian Discipleship Model..................................................... 40

Progression............................................................................. 41

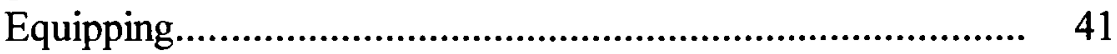

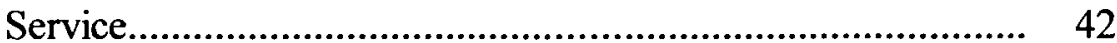

Building up....................................................................... 42

Purpose......................................................................... 43

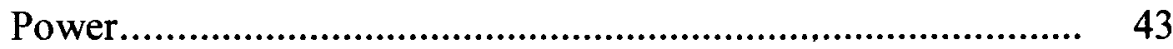

Ellen G White's Approach to Discipleship................................................ 44

The Pastor/Evangelists Role in Discipleship........................................... 44

Training for Ministry....................................................................... 45

Planning Work....................................................................... 46

Discipling with Different Approaches............................................. 46

The Churches Role in Discipleship.................................................... 47

Watchful Attention and Encouragement......................................... 47

Coaching New Converts........................................................... 48

The New Convert's Role in Discipleship............................................. 48

Cultivate Spiritual Formation.................................................... 49

Avoid General Dangers............................................................ 49

Discover and Use Spiritual Gifts................................................ 50

New Member Discipling Model...................................................... 51

Nurture and Instruction........................................................... 51

Fellowship Opportunities............................................................. 52

Assimilation Through Involvement................................................. 54

III. CORPORATE DISCIPLESHIP MODELS................................................. 56

Early Apostolic Model........................................................................ 56

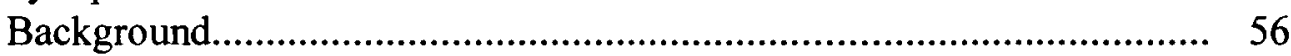

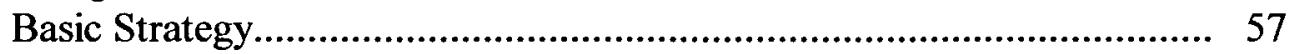

Wesley's Interlocking Group Model......................................................... 61

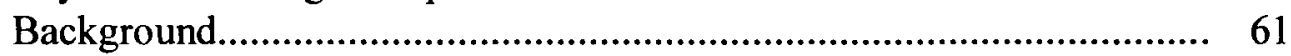

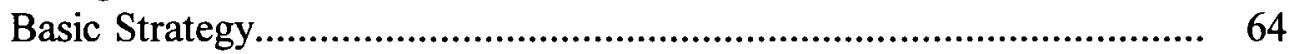

The Society: The Cognitive Mode................................................ 64

Class Meetings: The Behavioral Mode........................................... 65 
Band: The Affective Mode........................................................... 66

Penitent Band: The Rehabilitative Mode.......................................... 67

Selected Society: The Training Mode......................................... 67

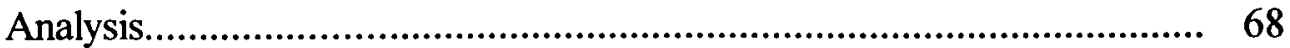

Contemporary Models........................................................................... 70

The Willow Creek Community Church................................................ $\quad 70$

Background............................................................................... 71

Basic Strategy............................................................................. 72

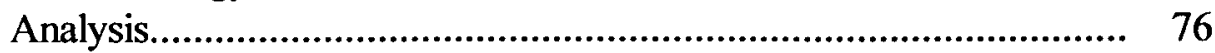

The Purpose Driven Model................................................................... 79

Background........................................................................ 79

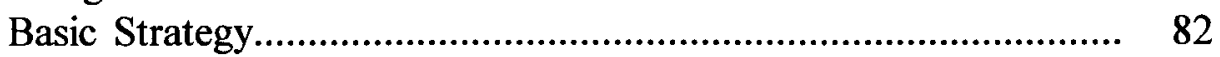

Analysis..................................................................................... 85

The Connecting Model........................................................................... 87

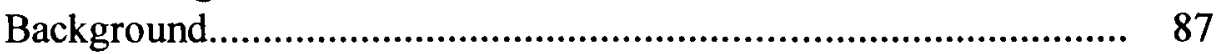

Basic Strategy ......................................................................... 90

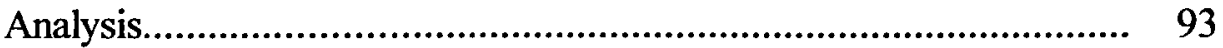

IV. PERSONAL MODELS OF DISCIPLESHIP............................................. 95

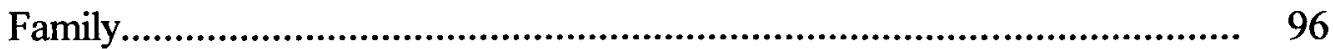

One-on-One Mentoring......................................................................... 97

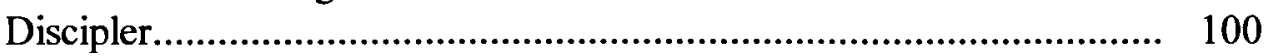

Spiritual Guide.......................................................................... 100

Coach

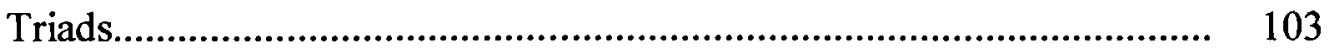

Small Groups..................................................................................... 105

Ministry Team................................................................................ 107

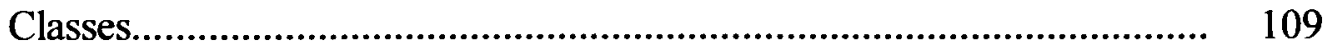

The Model for Seminarians at NBC............................................... 110

Development of the Model............................................................ 112

Trainee Selection.................................................................. 113

Field Site Selection............................................................. 114

The NBC Seminarians Model................................................ 116

The Coach Teacher Role........................................................... 124

Results/Obstacles/Evaluation.................................................. 126

V. THE DISCIPLESHIP OF NORTHEAST BRAZIL..................................... 130

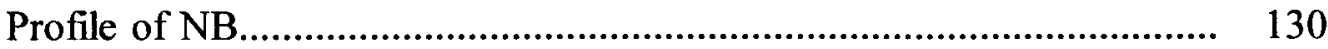

Brief History.......................................................................... 130

Demographics........................................................................ 132

The SDA Church...................................................................... 135 
The Field Study................................................................................... 137

Rationale for the Field Surveys and Interviews................................. 138

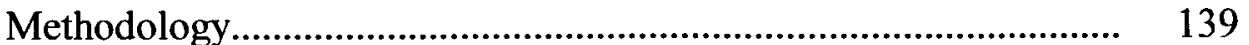

Analysis of Data........................................................................... 142

The New Disciple Survey....................................................... 142

Interviews of Former Adventists............................................. 150

Implications of the Information Obtained............................................... 159

Factors Contributing to the Deficit............................................ 160

Improper Equipping................................................................. 161

Improper Disciple-Making Focus............................................. 162

No Clear Pathway to Maturity............................................... 163

Unbalanced Models for Discipleship......................................... 165

Meeting the Needs of the New Disciples in NB.......................... 166

Need of Food........................................................................ 167

Need of Watchful Care........................................................... 168

Need of Fellowship................................................................. 168

Need of Instruction and Activities........................................ 169

Need of Maturity..................................................................... 170

VI. A DISCIPLESHIP MODEL FOR NORTHEAST BRAZIL.............................. 172

Description of the Model...................................................................... 172

Outreach Components........................................................................... 177

Cultivating through Presence Evangelism.................................... 179

Sowing through Proclamation Evangelism.................................. 180

Reaping through Persuasion Evangelism................................... 180

Inreach Components....................................................................... 181

Establishing through Nurture, Worship, and Fellowship............. 182

Equipping for Stewardship...................................................... 183

Mobilizing for Service.............................................................. 183

Structural Components.................................................................. 184

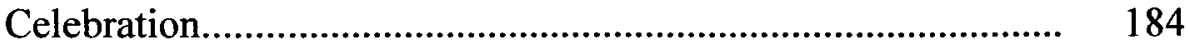

Congregation......................................................................... 185

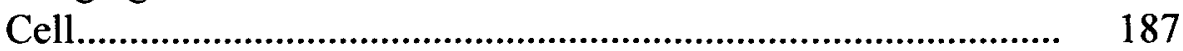

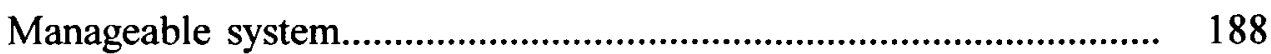

Levels of the Model....................................................................... 188

Model Implementation and Evaluation............................................. 206

VII. CONCLUSION AND RECOMMENDATIONS...................................... 215

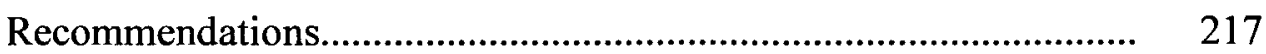

To the District Pastors and Elders........................................... 217

To Administrative Leaders...................................................... 218 
For Further Study........................................................... 219

Appendix

A. The Great Commission...................................................................... 221

B. The Purpose-Driven Model......................................................................... 224

C. The Connecting Model......................................................................... 226

D. The Manageable System............................................................................. 228

E. The Side Door and the Front Door............................................................. 230

F. The PERT System................................................................................ 232

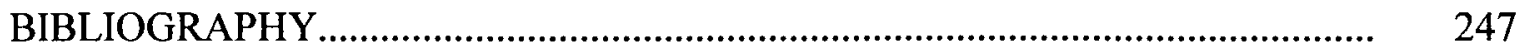

VITA 


\section{LIST OF TABLES}

1. One-on-One Mentoring...................................................................................... 99

2. Age and Gender of People Attending Evangelistic Meetings................................. 143

3. Marital Status, Occupation, and Religious Background of Converts...................... 144

4. Factors Influencing the Decision to Join the SDA Church.................................. 145

5. How Did People Learn about the Evangelistic Meetings?..................................... 148

6. Methods Used by New Converts to Witness for Christ..................................... 149

7. Age and Gender of Former SDA Members................................................... 151

8. Factors that Attracted Former Believers to the SDA Church.............................. 151

9. Crises that Influenced Former Believers to Be Receptive to Spiritual Matters....... 153

10. Length and Level of Instruction Received by Former Members before Joining the SDA Church...................................................................... 154

11. Symptoms Experienced by Immature Members................................................ 160

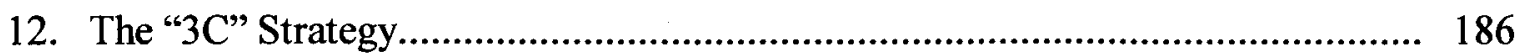

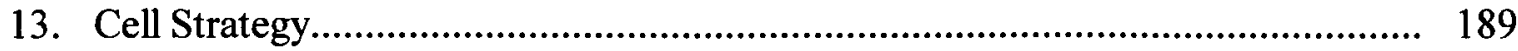

14. Discipleship Levels............................................................................... 205 


\section{LIST OF FIGURES}

1. Activities Influencing the Decision to Join the SDA Church ….............................. 147

2. Resources Strengthening the Spiritual Life of New Converts.................................... 148

3. Rating Church Participation of Former Members Before They Left the Church....... 155

4. Correlation between Small Group Participation and Social Pressure

Experienced by Former Members........................................................................... 156

5. Level of Witnessing and Giving Practices among Former Members........................... 156

6. Correlation between Activities and Giving Habits of Former Members........................ 158

7. Factors Influencing the Decision to Leave the Church According to

Former Members .......................................................................................... 159

8. The Transformational Model to Make Disciples...................................................... 175

9. The Spiritual Decision Process........................................................................... 178

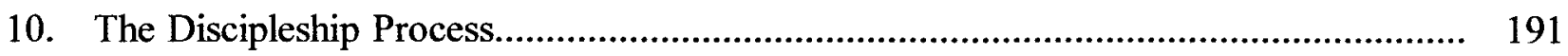

11. The Strategic Levels of the Model.......................................................................... 192 


\section{ACKNOWLEDGMENTS}

I am acknowledging, first of all, the great God and Father of our Lord Jesus

Christ, who by His wisdom and irrefutable will granted me the strength and wisdom to accomplish this project.

I want to acknowledge my wife, Gina, and my children, Samuel and Sammila, for their understanding and patience in giving me the time and support so greatly needed to finish this task. For the privilege of continuing my education I wish to thank Dr. Wilson Endruweit from the South American Division who approved and facilitated my efforts. Appreciation is also extended to the administrators of the Northeast Brazil Union Mission and from Northeast Brazil College who supported my studies at Andrews University for three years. Special recognition is given to Dr. Luiz Nunes for the insights and encouragement that grew out of mutual discussion and sharing during the course of this project, and to my parents who encouraged and prayed for me along the way.

Finally, I am greatly indebted to Dr. Ricardo Norton for his guidance of the project from inception to completion. Appreciation is also given to the members of the project committee, Dr. Eduard Schmidt, Dr. Nancy Vymeister, Bonnie Proctor for their helpful suggestions. 


\section{CHAPTER I}

\section{INTRODUCTION}

\section{Statement of the Problem}

Seventh-day Adventist churches have been growing rapidly in the territory of Northeast Brazil. ${ }^{1}$ Their numerical growth is phenomenal by any estimation. However, these churches are growing numerically and not in depth. We see a discipleship deficit among new believers, shown by a high rate of backdoor losses, unawareness of the meaning and duties of the discipleship, spiritually undisciplined members, absence of intentional relationships to share faith, biblical illiteracy, and lack of church fellowship. How can churches in Northeast Brazil (NB) grow in quality, reproducing, fully devoted followers of Jesus Christ?

${ }^{1}$ While in 2002 the South American Division had the largest baptismal growth among the world divisions of the Seventh-day Adventist Church (218,796), Northeast Brazil Union Mission (NBUM) ranked second in members, gained through baptisms, profession of faith, and letters received in the South American Division $(26,938)$, with 3.44 percent of annual growth, according to the $140^{\text {th }}$ Annual Statistical Report (Washington, DC: Review and Herald Publishing Association, 2002), 26, 36. In 2003, NBUM had an increase of 34,606 new members or 6.3 percent of growth according to the $140^{\text {th }}$ Annual Statistical Report (2003), 22, 23. 


\section{Statement of the Task}

The task of this project is to examine the importance of discipleship training from the biblical perspective with the purpose of devising an effective discipleship model for evangelism in NBUM.

\section{Justification for the Dissertation}

Justification for the project and the incentive for its undertaking were based upon the following points:

1. The apostasy rate among newly baptized members in Northeast Brazil is monumental ( 40 to 60 percent) and needs to be treated by focusing on disciples as an end product of the Great Commission. ${ }^{1}$

2. The reasons why members are leaving the church, as well as the growing number of church members becoming uncommitted, need to be investigated.

3. Discipleship training is an effective method of Christian ministry that stands on firm scriptural foundations and is capable of bringing church renewal and revitalization to the Seventh-day Adventist churches in NBUM.

4. An evaluation of my past ministry as a seminary teacher and evangelist in NBUM revealed that there is a need for a discipleship model that enables the church to accomplish its mission and help members to attain maturity.

${ }^{1}$ NBUM ranked first in dropped, death, and missing members among the unions of the South American Division with 15,101 in 2002, and 16,576 in 2003 respectively. These numbers represent a loss rate of 67 percent in 2002 and 53 percent in 2003. Ibid. 


\section{Definition of Terms}

Terms used within the dissertation and definitions as they apply to this project are as follows:

Disciple: "A disciple is one who has come to Jesus for eternal life, has claimed Jesus as Savior, and has embodied upon the life of following Jesus." Being a disciple is a lifelong process of dying to self while allowing Jesus Christ to come alive in us.

Discipleship: The process of growth into Christ-like maturity and reproduction. Fruitfulness in quality and quantity are the natural outcome. ${ }^{2}$

Model: A simplified description of a system, or a "preliminary representation of something, serving as the plan from which the final, usually larger, object is to be constructed." ${ }^{3}$

Strategy: An overall approach or way of describing how we will go about reaching our goal or solving our problem. According to Malphurs, this definition contains three important concepts. First, strategy has a mission or an overall goal to be pursued; second, it involves a process of moving people from spiritual prebirth to Christian

${ }^{1}$ Michael J. Wilkins, Following the Master: Discipleship in the Steps of Jesus (Grand Rapids, MI: Zondervan Publishing House, 1992), 40.

${ }^{2}$ Greg Ogden Lectures in the class "Growing a Disciple-Making Congregation," Fuller Theological Seminary, Aug. 4-15, 2003. "Model."

${ }^{3}$ Webster's New World Dictionary of American English, 3d college ed (1988), s.v. 
maturity; and third, it answers the question: How will you achieve your mission? In other words, a good strategy involves the action steps you take to get there. ${ }^{1}$

Evangelism: From the Greek noun euaggelion, "good news," and the verb euaggelizomai, "to proclaim good news." Evangelism is the presenting of Jesus Christ so that, by the power of the Holy Spirit, men shall come to put their trust in God through Him, to accept Him as their Savior, and to serve Him in the fellowship of the church. ${ }^{2}$

Evangelism involves a connected four step phase of contact, cultivation, commitment, and conservation-each depending on the others. This view makes it plain that it must be the work of the whole church through different approaches such as personal evangelism, crusade evangelism, open air evangelism, small groups, literature, radio, etc.

The following definitions were extracted from the Working Police of the General Conference of the Seventh-day Adventists:

Local Church: An united organized body of individual believers.

Conference/Mission/Field: A specific group of local churches, within a defined geographic area.

Union: A body of conferences/missions in its assigned area of the world.

'Aubrey Malphurs, Strategy 2000: Churches Making Disciples for the Next Millennium (Grand Rapids, MI: Kregel Publications, 1996), 44-47.

${ }^{2}$ F. Carlton Booth, "Evangelism in the Home Church," Baker's Dictionary of Practical Theology, ed. Ralph G. Turnbull (Grand Rapids, MI: Baker Book House, 1967), 171. 
Division: Embraces all the local or union conference/mission in its assigned area of

the world. ${ }^{1}$

\section{Delimitations of the Dissertation}

This discipleship and spiritual growth study was limited to Teresina, state capital of Piaui, in the NBUM. Although the surveys and personal interviews to discover factors that enhance and hinder discipleship applied specifically to the church of Teresina, the strategic principles can find general application in similar contexts in other large cities of Northeast Brazil, which have common cultural and socioeconomic factors. This study can provide a framework within which further study can be undertaken to discover new and innovative ways for discipleship in other cities of this area.

\section{Description of the Dissertation Process}

Current literature related to the problem was reviewed. The reading included books and articles on the principles, strategies, and programs to enrich my notion of discipleship in the context of evangelization. Factors responsible for the superficial discipleship and the loss of new members in Teresina were also investigated.

Personal and corporate models of discipleship were examined in order to create a holistic scheme that provides an integrative strategy of the various components of evangelism in order to effectively make disciples in Northeast Brazil. As a result, a

\footnotetext{
${ }^{1}$ General Conference of Seventh-day Adventists, Working Policy of the General Conference of Seventh-day Adventists (Hagerstown, MD: Review and Herald Publishing Association, 2000), 47.
} 
discipleship model for evangelism in Northeast Brazil was created to help new converts become responsible Christians.

Chapter 1 introduces the dissertation, while chapter 2 gives a biblical basis for discipleship. Chapter 3 presents corporate models employed for discipleship, and chapter 4 review current methods of discipleship as well as the ministerial training program at Northeast Brazil College.

Chapter 5 describes aspects of Northeast Brazil such as the land and its people, demographics, and the SDA church. It also presents a descriptive statistical analysis from a survey that was conducted in Teresina, Northeast Brazil, as part of an evangelistic effort carried out by seminarians of the Northeast Brazil College.

Chapter 6 develops a suggested model for discipleship. Finally, chapter 7 provides a summary, conclusions, and recommendations. 


\section{CHAPTER II}

\section{FOUNDATIONS FOR DISCIPLESHIP}

This chapter considers a number of elements presented in Scripture on the concept of discipleship. Biblical examples are given, along with Ellen White's counsel, on the importance of the discipleship process as a key to God's plan to strengthen the church and to reach the world by raising up a group of men and women who reflect His own character.

\section{The Great Commission}

The Great Commission represents the commanded work agenda for the Christian church and its reason for existence. The most detailed and complete summary of the Great Commission is Matt 28:19, 20. In the other four appearances, Mark 16:15, 16 repeats baptizing but adds preaching; Luke 24:47, 48 repeats preaching but adds witnessing; John 20:21 mentions sending; and Acts 1:8 assigns the working territory for the Great Commission.

A careful analysis of Matt 28:19, 20 reveals four elements that make up the commission (see appendix A). The first three involve the participles "going," "baptizing," and "teaching," and the fourth is the imperative "make disciples." The first element is the participle "going." Many Greek grammarians believe that, though the main verb is to 
"make disciples," this does not reduce the participle "going" to a mere non-imperative sense. Rather, the construction indicates that "going" is an integral part of making disciples and is to be translated as an imperative. ${ }^{1}$

Gary L. McIntosh, in his book Biblical Church Growth, affirms that the first participle, "going," "picks up the force of the command and is thus correctly translated as an imperative "go." He also says that, "without the action of going, it is impossible to make disciples. It makes the command definite and intentional." ${ }^{\text {3 }}$ McIntosh points out that "it is not, if you happen to be going, but go! This indicates a sense of urgency. We are not to wait casually for some accidental contact, but we are to go."4

The intentional pursuit of lost people reflected in the word "go" is clarified in passages such as Luke 5:27-32;15:1-10; and 19:1-10. To put it simply, we need to move from a strategy of invitation to one of infiltration, from an inviting church to an invading church.

The participle "baptizing" signifies the manner in which the action of the main verb "make disciples" is accomplished, and implies a bonding of new believers to Christ and His church. In such a construction it would not be good theology to say that, because the

'See Cleon Rogers, “The Great Commission,” Bibliotheca Sacra 130 (July 1973): 258-67; Donald A. Hagner, "Matthew 14-28," Word Biblical Commentary (Dallas, TX: Words Books, 1982), 886; H. E. Daha and Julius R. Mantey, A Manual Grammar of the Greek New Testament (New York: MacMillan, 1927), 229; Frederic Dale Brunner, “Matthew," vol. 2, The Churchbook (Dallas: Word, 1990), 2: 1096.

${ }^{2}$ Gary McIntosh, Biblical Church Growth: How You Can Work with God to Build a Faithful Church (Grand Rapids, MI: Baker Books, 2003), 65.

${ }^{3}$ Ibid.

${ }^{4}$ Ibid., 66. 
word baptizing precedes the word teaching, therefore people must be baptized before they are taught. The Bible implies that to be ready for baptism requires repentance (Acts 2:38, 41) and also "receiving the word" (Acts 2:41).

According to Jesus' commission, people are first to be made disciples (Matt 28:18), then they are baptized into the body of Christ, which the New Testament clearly defines as the church of Jesus. ${ }^{1}$ Interestingly, Donald McGavran notices that Adventists, who have practiced a stronger pre-baptismal process, hold onto converts better than do those groups who only teach an initial coming to Christ. $^{2}$

The last participle in the Great Commission is "teaching." William Hendriksen, in his New Testament Commentary, remarks that this teaching both precedes and follows baptizing. ${ }^{3}$ Baptizing and teaching logically follow the imperative to "make disciples," and these two parallel participles describe the means by which disciples are made. ${ }^{4}$

Teaching is to be an ongoing process of maturation of all believers as they are taught all things. ${ }^{5}$ That such teaching should not stop when a person has been baptized is clear from the words of vs. 20. Christ stated that the content of teaching was to be all that

'Eddie Gibbs, I Believe in Church Growth (London: Hodder and Stoughton, 1992), 136.

${ }^{2}$ Donald McGavran, Understanding Church Growth, 3d ed., ed. and rev. C. Peter Wagner (Grand Rapids, MI: Eerdmans, 1990), 132.

${ }^{3}$ William Hendriksen, "Exposition of the Gospel according to Matthew," New Testament Commentary (Grand Rapids, MI: Baker Books, 1973), 1001.

${ }^{4}$ lbid.

${ }^{5}$ Gibbs, 66. 
He has commanded them. That would include all the lessons from His discourses, parables, commands, predictions, and promises.

In his relationship with new members, Paul closely followed this instruction (1 Cor 11:23). He exhorted Timothy to teach faithful men so that they, in turn, could teach others (2 Tim 2:2). He makes a striking statement about the truth to be taught early in the development of the believer $(\mathrm{Heb} 6: 1,2)$, and encourages deeper teaching to mature churches about the priesthood of Melchizedek, the sanctuary, and the doctrine of the new covenant. His curriculum also included eschatological matters ( 1 Thess $4: 13-18$; 1 Cor 15:50-58) and practical Christian living (1 Cor 8; 10:14-22; 5:1-10). In light of what we have been saying about the Great Commission, mission is not complete until all three aspects of the task have been accomplished. Only as the church follows this threefold mandate can it claim to be fulfilling the Gospel Commission. Thus, if a church baptizes people without discipling or teaching them, it is disobedient to Christ. ${ }^{1}$

\section{Definitions}

This section gives a definition of disciple, discipling, and discipleship from the Bible, Ellen G. White, and other contemporary commentators and church-growth writers.

${ }^{1}$ Burrill, 12. 
Disciple

Many definitions of "disciple" are given in church-growth literature, but they seem to be contrived for missiological reasons rather than as a strictly biblical definition. ${ }^{1}$

Mathetes is understood as a term for someone who stands in relation to another pupil and is instructed by that person. ${ }^{2} \mathrm{He}$ or she binds himself to someone else in order to acquire his practical and theoretical knowledge. ${ }^{3}$ Rengstorf affirms that a unique aspect of NT discipleship is that "it is commitment to the person of Jesus," and he adds, "His teaching has force only when there is first this commitment to His Person."

Those definitions parallel Wilkins's, in his book Following the Master:

Discipleship in the Steps of Jesus. In the general sense he defines a disciple as "a

'Michael J. Wilkins, Following The Master: Discipleship in the Steps of Jesus (Grand Rapids, MI: Zondervan Publishing House, 1992), 25-31, shows several models of discipleship: (1) Disciples are learners of a great teacher but there is no reference to whether or not the person is a Christian; (2) disciples are committed believers, and in the church there are two levels: disciples and ordinary disciples; (3) disciples are ministers, called out among lay believers in order to enter into ministry, thus making class distinction; (4) disciples are converts; discipleship comes later. Proposed by Donald McGavran, this model suggests that a disciple is one who has been evangelized, and the later process of growth is called "perfecting"or "discipleship." But it seems inconsistent with Matt 28 and the terms of the New Testament, and this definition has cheapened the gospel with McGavran's idea of bringing entire groups to Christ without instruction.

${ }^{2}$ P. Nepper-Christensen, "Mathetes, " Exegetical Dictionary of the New Testament, ed. Horst Boltz and Gerhard Schneider (Grand Rapids, MI: Eerdmans Publishing Company, 1990), 2:372.

${ }^{3} \mathrm{D}$. Muller, "Word," The New International Dictionary of the New Testament Theology, ed. Colin Brown (Grand Rapids, MI: Zondervan, 1986), 1:484.

${ }^{4} \mathrm{~K}$. H. Rengstorf, “Mathetes," Theological Dictionary of the New Testament, ed. Gerhard Kittel and Gerhard Friedrich, trans. Geoffrey W. Bromiley (Grand Rapids, MI: Eerdmans, 1964-76), $1: 560$.

${ }^{5}$ Ibid. 
committed follower of a great master." In the specific sense, "a disciple of Jesus is one who has come to Him for eternal life, has claimed Jesus as Savior and God, and has embarked upon the life of following Him."”

At this point I wish to examine the statements of Jesus regarding becoming a disciple. Jesus had in mind these statements when He commanded His followers to make disciples.

1. A disciple understands and keeps the basic teachings of Jesus (John 8:31-32).

2. A disciple loves unconditionally with the agape love of Jesus received from Him (John 13:34).

3. A disciple lives in total allegiance to the lordship of Christ, willing to forsake all-property, family, friends-for the sake of Christ (Luke 14:16, 27, 33).

4. A disciple bears fruits by multiplying himself or herself in other disciples for Christ (John 15:8).

5. A disciple is one who is willing to endure persecution and ridicule for the sake of Christ (Matt 10:24-25).

6. Jesus declared that to be a disciple is to become like the Master (Matt 10:24-25; Luke 6:40) in the same ministry, message, suffering etc.

A list of the passages dealing with Jesus' understanding of what it means to become a disciple brings into focus one of the most controversial issues about the

\footnotetext{
'Wilkins, 40.

${ }^{2}$ Ibid.
} 
definition of the word "disciple:" Is there a biblical distinction between being a Christian and being a disciple? From the book of Acts we see that the term "disciple" is synonymous with "true believer" in Jesus (Acts 6:1, 2; 6:7; 9:26; 14:21-22), and that in Antioch "the disciples were called Christians" (Acts 11:26). Although the word "disciple" does not occur in the epistles, the term is naturally expressed in other terms such as "believers," "Christians," "brothers and sisters," and "servants."

In Acts the common name for a believer is disciple "to show that the relationship that Jesus had had with the Twelve remained the pattern of His relationship with the Church." The fact that the disciples themselves adopted the designation "Christians" indicates that they completely identified themselves with Christ and fully dedicated themselves to His service. ${ }^{3}$ As mentioned earlier, the term "disciple"emphasizes devotion to a leader rather than to his/her doctrine or cause.

It is evident, then, that repentance and belief in the gospel do not automatically make one a true disciple of Jesus. Identification with and dedication to Christ are not common qualities of church members today, as they were in the early church. For example, being a convert or Christian does not necessarily mean that the converts are ready to make converts. Many Christians are spiritually sterile; they do not take the gospel

\footnotetext{
${ }^{1}$ Ibid., 291-301.
}

${ }^{2}$ David J. Williams, "Acts," New International Biblical Commentary (Peabody, MA: Hendrickson Publishers, 1990), 5:116.

${ }^{3}$ Simon J. Kistemaker, "Exposition of the Acts of the Apostles," New Testament Commentary (Grand Rapids, MI: Baker Book House, 1995), 423. 
forward. Besides, the low level of commitment and holiness of character show that the church is not living up to expectations.

To those Seventh-day Adventists who claim to be Christians but have not understood the implications of a living disciple's life, Ellen White states emphatically, "Not all who profess to be workers for Christ are true disciples. Among those who bear His name, and who are even numbered with His workers, are some who do not represent Him in character. They are not governed by His principles." She also affirms, "Every true disciple is born into the Kingdom of God as a missionary. He who drinks of the living water becomes a fountain of life. The receiver becomes a giver."

\section{Discipling and Discipleship}

As already noted, the biblical picture of God's objectives for Jesus' disciples is Christlikeness of character, fruitfulness in service, and an intimate relationship with the Lord. The terms "discipleship"and "discipling" are English words derived, obviously, from disciple. $^{3}$ According to Rengstorf, in a distinctive transitive use, the term matheteuo is used for "to make disciples" (Matt 13:52; 28:19; Acts 14:21). ${ }^{4}$

'Ellen G. White, The Ministry of Healing (Mountain View, CA: Pacific Press Publishing Association, 1942), 493. See also idem, Christian Service (Washington, DC: Review and Herald Pub. Assn., 1983), 35-49, where Ellen G. White denounces the state of spiritual weakness and selfcomplacency among Seventh-day Adventists; and idem, Testimonies for the Church, 9 vols. (Mountain View, CA: Pacific Press Pub. Assn., 1940), 5:168. 195.

${ }^{2}$ Ellen G.White, The Desire of Ages (Mountain View, CA: Pacific Press Pub. Assn., 1940),

\footnotetext{
${ }^{3}$ Wilkins, 41 .

${ }^{4}$ Rengstorf, 1:562.
} 
Greg Ogden, an outstanding teacher on discipleship, has given some important insights on this issue in his classes and writings. He defines discipleship as "the process of growth into Christ-like maturity and reproduction."1 He shows the value of this ongoing process of growth and states that "you become a Christian disciple by choosing to follow Christ in such a way that your core ambitions are changed, so you are no longer serving self first but God. Then your process of growth as Christians is called discipleship."2

Discipling, according to Ogden, implies the responsibility of disciples helping one another to develop and mature as disciples. It is "an intentional relationship in which we walk alongside other disciples in order to encourage, equip, and challenge one another in love to grow toward maturity in Christ. This includes equipping the disciple to teach others as well."

Bruner's explanation of the word discipling makes a distinction between disciplemaking leading to baptism and the continuation of disciple-making after baptism.

Only the Cosmocrator can do the big things like convert, win, bring repentance, or move a person to a decision-all authority is His alone. But disciples can, must, and will spend good time with people-in the confidence that sooner or later the Cosmocrator will create in these people the decision for baptism (or, in Christianized cultures, the decision to own baptism) and so follow Jesus. ${ }^{4}$

Bruner further notes:

'Greg Ogden, Lecture, “Growing a Disciple Making Congregation,” Fuller Theological Seminary, Aug. 4-15, 2003.

${ }^{2}$ Ibid.

${ }^{3}$ Greg Ogden, Discipleship Essentials: A Guide to Building Your Life in Christ (Downers Grove, IL: InterVarsity, 1998), 17.

${ }^{4}$ Bruner, 1096. 
First comes discipling (meaning something like our evangelizing), which Christians workers then (second) bring to a climax in baptizing (meaning initiating and empowering), and which they then (third) continue by a life-long teaching of all Jesus' commands (meaning Christian education or catechizing). Discipling reaches its first goal in the once-for-all act of baptism and (discipling is continued) through the ongoing activity of teaching. ${ }^{1}$

This explanation is more in harmony with the Great Commission ideal by suggesting that discipling is both an initial work and a continuing work in the life of the person being discipled. ${ }^{2}$ As the Great Commission mandates, people are brought to Jesus in obedience to the intentional command to "go" and embark upon a life of following Him in order to grow toward maturity. Before baptism, people are taught what Jesus meant by being a disciple through intentional relationship with another disciple, and after baptism the teaching process continues, aiming at maturation in Christ and multiplication as well.

In the light of what has been said about discipleship, we come to the biblical picture of the elements of the Great Commission (see appendix A).

\section{Jesus' Discipleship Model}

Jesus Christ began His mission with a personal ministry of a little more than three years. One of the key aspects of that time was His training of the twelve disciples, whom He named apostles. That training was the foundation of His whole ministry. Much of His time during those three-plus years was concentrated on these men. He knew that in order for His mission to succeed, much would depend on the dedication, loyalty, and faith of the men whom He had chosen and trained.

\footnotetext{
${ }^{1}$ Ibid., 1102.

${ }^{2}$ Burril, 17.
} 
What was the relational, developmental process that Jesus took these disciples through so that they would be ready to carry on His mission? How did Jesus go about shaping and training the twelve to become fishers of people? Attempts have been made to fit the gospel content into distinct phases, as if Jesus has been operating out of a sequential leadership development model. ${ }^{1}$ At least five guiding principles of Jesus' methodology, which correspond with the major turning points in Jesus' public ministry are evident: the seeker/selection phase, the life transference phase, the instruction phase, the deployment phase, and the reproduction phase.

\section{The Seeker/Selection Phase}

A close reading of John 1:39-45, Mark 1:14-20, and also 3:13-14 reveals that disciples becoming part of Jesus' inner circle progressed through stages. A. B. Bruce, in the Training of the Twelve, suggests that responding to Jesus' selection to be a part of the inner group was the third of three stages in a process. ${ }^{2}$

The first stage is recorded in John 1:39-46. The followers did not at this time permanently discontinue their usual occupation and become disciples in the full sense of

'Robert E. Coleman, in the Master Plan of Evangelism, 2nd ed. (Grand Rapids, MI: Baker Book House, 1993), sketches various phases of the evangelistic message and methodology of Jesus: selection, association, consecration, impartation, demonstration, delegation, supervision, and reproduction. Greg Ogden, in Transforming Discipleship: Making Disciples a Few at a Time (Downers Grove, IL: InterVarsity Press, 2003), 83-98, prefers to describe the shaping and training of the Twelve in five steps: the inquiry stage, Jesus the example, Jesus the teacher, Jesus the coach, and Jesus the delegator. And Michael J. Wilkins, in Following the Master, 101-119, presents five stages: personal initiative to follow Jesus, Jesus' call, Jesus sifts the followers, the limited group of followers, and the early church.

${ }^{2}$ A.B. Bruce, The Training of the Twelve (Grand Rapids, MI: Kregel, 1971), 11. 
the word. ${ }^{1}$ John indicates that the initial encounters with Jesus initiated a period of examination. They became inquirers or seekers ("come and see"). They did so simply in the sense of accepting John's witness to the Messiahship of Jesus. ${ }^{2}$ In the second stage, about a year later, in the spring of A.D. 29, they received the call to permanent discipleship (Luke 5:1,11). Now Jesus called them to forsake their former life and unite their interests with His ("follow Me"). In the third stage, the formal appointment of the Twelve comes even later, during the summer of the same year (Mark 3:14). ${ }^{4}$

According to Luke 6:12-15, apparently there was a somewhat larger group of followers from which the Twelve were selected. The call was not based so much on their desire as upon His (John 15:16). None of the Twelve was chosen because of perfection, either in character or in ability. "Christ selected men who were willing and able to learn, whose characters might be transformed." Leroy Eims, in the Lost Art of Disciple Making, underscores the value of this principle by affirming that "in our making disciples, we should not select only those who are like us in temperament and personality. Nor should

'White, The Desire of Ages, 246.

${ }^{2 " F o l l o w e d ~ h i m " ~[J o h n ~ 1: 40], ~ T h e ~ S e v e n t h-d a y ~ A d v e n t i s t ~ B i b l e ~ C o m m e n t a r y ~(S D A B C), ~ e d . ~}$ Francis D. Nichol (Washington, DC: Review and Herald Publishing Association, 1976-80), 5:910.

${ }^{3}$ White, The Desire of Ages, 249.

4“Followed" [John 1: 37], SDABC, 5:909; see also White, The Desire of Ages, 290-297. ${ }^{5} \mathrm{SDABC}, 5: 592$; see also White, The Desire of Ages, 250. 
we choose only those who act in certain ways that we find agreeable to our personal lives and acceptance standards."

It is important to note that Jesus' decision to have twelve disciples did not exclude others from following Him (Luke 10:1). Ogden rightly observes that "all apostles are

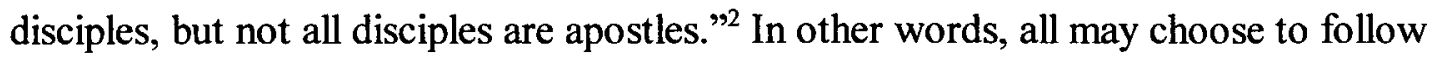
Christ, but it is He who chooses and qualifies people to occupy positions of responsibility and leadership in His cause (1 Cor 12:7-11, 28).

Finally, by focusing on a few, Jesus was not displaying indifference to the multitudes. Robert Coleman captured Jesus' methodology when affirming that the first thing He did when He started His ministry was "to identify Himself boldly with the great mass revival movement of His day by baptism at the hands of John (Mark 1:9-11; Matt 3:13-17; Luke 3:21, 22)." ${ }^{3}$ However, the genius of Jesus' strategy was "to devote Himself primarily to a few men, rather than the masses (though $\mathrm{He}$ did what He could to help the multitudes), so that the masses could at last be saved." Multiplication was the strategic reason why Jesus focused on a few because "multitudes can be won easily if they are just given leaders to follow."

${ }^{1}$ Leroy Eims, The Lost Art of Disciple Making (Grand Rapids, MI: Zondervan Publishing House, 1978), 30.

${ }^{2}$ Ogden, 63.

${ }^{3}$ Coleman, 32 .

${ }^{4}$ Ibid., 36.

${ }^{5}$ Ibid., 37. 
The Life Transference Phase

The next step in Jesus' discipleship methodology was life transference. Mark makes it clear that Jesus appointed them, first of all, to spend some time with their Master, seeing and hearing Him, and learning whatever He wished to teach them (Mark 3:14). Ellen G. White has argued this point. She shows us that when Jesus called them to be His co-laborers, first "He gave them the advantage of association with Himself." This was not a revolutionary idea in His day, for there are numerous instances in the Old Testament where men were trained for the work of God by association with other men of God (1 Kgs 19:15-16, 19; Num 27:15-20). White adds later that "He did not command the disciples to do this or that, but said, 'Follow Me.' On His journeys through country and cities, He took them with Him, that they might see how He taught the people."2

It appears that early in Jesus' ministry the role of the disciples was to be quiet observers. Coleman captures this phase well by saying, "This was the essence of His training program-just letting His disciples follow Him."3 They traveled with Him from place to place. They were almost constantly with Him, witnessing His miracles (Mark $1: 40-45 ; 2: 1-12$ ) and hearing His words (Matt 5:5; 6; 7; Mark 4). All the disciples had serious faults when Jesus called them to His service. During this phase Jesus reproved His disciples (Mark 4:40) and warned and cautioned them (Mark 9:33-40; 10:13-16). They

\footnotetext{
'White, The Desire of Ages, 250.

${ }^{2}$ Ellen G. White, Acts of the Apostles (Boise, ID: Pacific Press Publishing Association, 1989),
} $17,18$.

${ }^{3}$ Coleman, 41 . 
chose Jesus, not withstanding the reproofs, and "by beholding Christ, they became transformed in character."1

Allan Coppedge provides an excellent overview of the principle of Life Transference presented in Jesus' relationship to the Twelve. He affirms that "when He called them to follow Him, He created an atmosphere in which He could pour His life into theirs. Jesus taught and lived out truth before them. He told His disciples how to minister to others, and gave them concrete examples of how to do it."

This life-to-life sharing process in a variety of life situations over a long period of time allowed Jesus to impart more than concepts and lessons. He gave the disciples His peace by which He was sustained in tribulations (John 16:33), and His joy in which He labored amid sufferings and sorrows $(15: 11 ; 17: 13)$. He imparted to them a vision of the need for world evangelization (4:34-38), ordained them to the gospel ministry (Mark 3:14), and finally, empowered them through the Holy Spirit to carry on the redemptive mission of evangelism (John 20:22; Acts 2:2). ${ }^{3}$

From this discussion it may be concluded that in a number of current so-called discipleship programs involving classes, manuals, and completion of courses; but little concern for personal association, real biblical discipleship does not happen. Unless life is shared with life, true discipleship as Jesus carried it out is not taking place. It is also

${ }^{1}$ White, The Desire of Ages, 296.

${ }^{2}$ Allan Coppedge, The Biblical Principles of Discipleship (Grand Rapids, MI: Zondervan Publishing House, 1989), 62.

${ }^{3}$ White, The Desire of Ages, 296. 
significant, as shown in Mark 3:14, that learning to be with Jesus was the top priority so that the resulting relationship might transform individuals and prepare them for service. Finally, we see the importance of personal example (John 13:15) for everyone who wants to be a disciple maker. Coleman is correct in saying that "we cannot give something away we do not possess ourselves." He adds: "We must have His life in us by the Spirit if we are to do His work and practice His teaching."”

The Instruction Phase

Jesus chose to be known as "teacher" (John 13:13). Teaching was His customary method of presenting truth, as indicated in Mark 10:1. He taught in the synagogues, in the streets, and in the temple. He taught in the desert and by the seaside. ${ }^{3}$ He even used a fishing boat as His pulpit, for "He sat down, and taught the people out of the ship" (Luke $5: 3)$.

In addition to taking the disciples with Him that they might see how He taught the people, ${ }^{4}$ Jesus also had special times of instruction with them. He told them, "The secret of the Kingdom of God has been given to you. But to those on the outside everything is said in parables" (Mark 4:11). Jesus' teaching of the disciples occurred in His ministry. Class was always in session, for He was not restricted to a set classroom, and lessons varied

'Coleman, 68.

${ }^{2}$ Ibid.

${ }^{3}$ R. R. Breitigam, The Teacher Sent from God (Mountain View, CA: Pacific Press Pub. Assn., 1960), $2,3$.

${ }^{4}$ White, The Acts of the Apostles, 18. 
with circumstances. Ogden is certainly correct in saying that "first the disciples heard or observed Jesus in His public ministry, and then with regularity Jesus turned to them to offer further explanation (Mark 4:10-20; 7:17-23; 10:26-31) or to pose questions (Mark 8:27)."1

From a quick survey of these instructions, it is evident that Jesus aimed to prepare the disciples to be workers with God for the salvation of men. He taught them "the truth that in God's Kingdom there are no territorial lines, no castles, no aristocracy; that they must go to all nations,"2 by taking them to Tyre (Mark 7:24-30) and to Sychar (John 4). He taught them to come into unity of feeling, thought, and action in order to carry forward the work to which they had been called (John 17:21, 23). ${ }^{3}$ He explained to them the basic principles of prayer and illustrated them through a model prayer (Luke 11:1-4; Matt 6:913).

Before their missionary journey, they were specifically instructed to preach and exercise caring ministries (healing the sick, cleansing lepers, and casting out demons) as a part of their task (Matt 10:7, 8). Jesus gave them instructions regarding finance (10:8-10), strategy for ministry (10:5, 11-15), and also training in meeting opposition (10:16-23). After setting a number of instructions before His disciples, Jesus reminded them of the purpose of the disciple's training: The disciple is to be like the teacher (10:24-25).

\footnotetext{
'Ogden, 87.

${ }^{2}$ White, The Acts of the Apostles, 19.

${ }^{3}$ Ibid., 20.
} 
Finally, Jesus specified the cost of being His disciple (10:28-36). It is imperative that people do not enter into discipleship training with their head in the clouds. It is interesting to note that when Jesus chose Paul, He gave him a glimpse through Ananias of what was waiting for him by saying that "he must suffer for my name" (Acts 9:15-16). White supports this idea by affirming that Jesus "did not deceive them with false hopes," but was "plain and definite" ${ }^{2}$ in speaking of their future in order to encourage and prepare them to carry on the work.

In this third phase Jesus utilized the concept of association and example, and $\mathrm{He}$ had specific times of solid, clear, plain instruction. He taught the basic ingredients in a life of discipleship (how to pray, the secret of a victorious life as presented in John 15, and how to work). He had a workable plan to help them accomplish it, and He told them about the cost of discipleship.

\section{The Deployment Phase}

In the fourth phase of Jesus' discipleship model, Jesus acted as a supportive coach by sending the Twelve and the Seventy out on a short-term mission opportunity. ${ }^{3}$ The account of the sending forth of the Twelve (Matt 10) begins with a problem in meeting people's needs (Matt 9:36). Jesus is now able to clarify the difficulty of the problem that they face, "The harvest is plentiful, but the laborers are few" (vs. 37). The solution to the

$$
\begin{aligned}
& \text { 'Ibid., } 21 . \\
& { }^{2} \text { Ibid. } \\
& { }^{3} \text { Ogden, } 92 .
\end{aligned}
$$


problem seems to be twofold. First, He exhorts His disciples to pray, for after praying Christians may find themselves burdened for specific peoples and may seek ways to minister to them. ${ }^{1}$ Second, He gives them authority and sends them out to minister (Matt 10:1, 5). Coppedge says that, through the principle of multiplication of disciples, "Jesus multiplies Himself by twelve and so begins to do twelve times the ministry that $\mathrm{He}$ did alone.,2 Not only does Jesus multiply Himself by twelve, but in Luke $10 \mathrm{He}$ multiplies Himself by seventy.

The Twelve, who thus far had assisted Jesus in His ministry, ${ }^{3}$ were now to be sent forth to labor alone. White underscores the coaching aspects of the relation of Jesus to the disciples by saying that "while He was personally with them, to point out their errors, and counsel and correct them, the Savior sent them forth as His representatives." ${ }^{.4}$ Like baby birds Jesus' disciples needed to be pushed out of the nest to see if they were going to fly. Their preparation for the mission was grounded in specific "instructions" (Matt 10:5), clear authority (10:2), and clear expectations (10:16-42). They went two by two (Mark 6:7; Luke 10:1), brother with brother and friend with friend. ${ }^{5}$

Perhaps before Jesus left Capernaum or while He traveled to the feast of Tabernacles, He appointed the Seventy, giving them definite assignments and taking them

'See Craig S. Keener, "Matthew," The IVP New Testament Commentary (Downers Grove, IL: InterVarsity Press, 1997), 1:198.

${ }^{2}$ Coppedge, 83 .

${ }^{3}$ White, The Desire of Ages, 349.

${ }^{4}$ Ibid.

${ }^{5}$ Ibid., 350. 
out into the ministry. ${ }^{1}$ According to White, the Seventy spent some time with Jesus, in training for their work. And, when the Twelve were sent out on their first separate mission, "they had the privilege of intimate association with Him, and direct personal instruction. Now this larger number also were to go forth on a separate mission." ${ }^{" 2}$ The instructions given to this larger group were essentially the same as those delivered earlier to the Twelve (Luke 10:2-16), but the command to the Twelve, not to enter into any city of the Gentiles or of the Samaritans, was not given to the Seventy.

The Twelve and the Seventy engaged in this short-term mission project with the full knowledge that Jesus would be there for the debriefing upon their return. After a number of weeks, an evaluation meeting took place where the Twelve made a thorough report of what had taken place during the course of their mission (Mark 6:30).

They laid before Him their favorable and unfavorable experiences, their joy in the results, their faults, and their failures; ${ }^{3}$ as well, they held communion with Jesus and received more instructions. ${ }^{4}$ Like the apostles, when the work of the Seventy was completed, they reported to Jesus the results of their mission (Luke 10:17). In the analysis and reflection that followed this supervisory meeting, Jesus cautioned them against being proud of their accomplishments (Luke 10:20). ${ }^{5}$

"'He departed from Galilee" [Luke 10:1], SDABC, 5:452.

${ }^{2}$ White, The Desire of Ages, 488.

3Ibid., 359.

${ }^{4}$ Ibid., 360 .

${ }^{5}$ Robert C. Tannehill, “Luke,” Abingdon New Testament Commentaries (Nashville: Abington Press, 1996), 179. 
From the discussion of the deployment phase of Jesus' ministry, I have recognized a number of advantages of this supervised short-term mission: (1) it provided a measurable and moderate risk task for the disciples in order to help them grow in confidence and competence; (2) it provided a balance between teaching ministry, doing ministry, and reflecting upon that experience so important toward their formation for ministry; (3) it provided supervision and guidance until such time as they were mature enough to carry on alone.

The Reproduction Phase

The time had come to send the disciples on their mission of reproduction. Jesus intended that His ministry in the Spirit would be multiplied by His ministry in the lives of His disciples. Coleman comments that "through them and others like them it would continue to expand in an ever-enlarging circumference until the multitudes might know in a similar way the opportunity which they had known with the Master."'

Christ knew that the time had come for Him to depart this world and go to His Father. On His last evening with the disciples, Jesus had much to tell them. After giving them an example of humility and unselfish ministry (John 13:1-20), He announced that He would soon leave them (13:33). Then He proceeded to comfort them by revealing that His departure would be only temporary (14:1-3), and that it would be for their benefit because of the coming of another Helper (14:15-17). After admonishing them on union with Him

'Coleman, 97. 
for spiritual life and fruitfulness (15:3-16), predicting persecution and the work of the Spirit (16:1-16), He concluded His parting counsel with a prayer (17:1-23).

After the death of Christ the disciples were overcome by discouragement. Luke gives us the most detailed accounts of facts after Jesus' resurrection. He tells us that for forty days Christ remained on the earth, preparing the disciples for the work before them (Acts 1:3) ${ }^{1}$, and reaffirming their commitment to reproduction (Luke 24:45-48). Just before leaving His disciples, Christ gave them the Great Commission to make disciples (Matt 28:19, 20) and a new endowment of power to fulfill their mission (Luke 24:49; Acts $1: 5,8)$.

The perpetual multiplying of disciples reflects Christ's strategy for reaching "the ends of the earth" (Acts 1:8). The Christian work is never finished until it has assured its continuation in the lives of those redeemed by the gospel. Herschel H. Hobbs has wisely said, "The work of evangelism is never complete until the evangelized becomes the evangelizer."2 Coleman makes a similar point, arguing that

the test of any work of evangelism is not what is seen at the moment, or in the Conference Report, but in the effectiveness with which the work continues in the next generation. Similarly the criteria upon which a Church should measure its success is not how many names are added to the roll nor how much the budget is increased, but rather how many Christians are actively winning souls and training them to win the multitudes. ${ }^{3}$

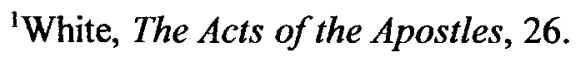

${ }^{2}$ Herschel H. Hobbs, quoted in Billie Hanks, Jr., "The Vision for Multiplication;" in Discipleship: Great Insights from the Most Experienced Disciple Makers, ed. Billie Hanks, Jr., and A. Shell (Grand Rapids, MI: Zondervan, 1993), 24.

${ }^{3}$ Coleman, 103. 
In conclusion, the church's great evangelistic task will be carried out only when the philosophy of ministry is updated through a reexamination of the principles revealed in the discipleship model of Christ.

\section{Paul's Discipleship Model}

As was already seen in the example of Jesus, the discipleship process is a key to God's plan both to strengthen the church and to reach the world by raising up a group of men and women who reflect His own character.

With all his natural gifts and the charisma of his presence, Paul was also theologically prepared under Gamaliel for his calling as an apostle (Acts 22:3; Gal 1:14). Following his conversion, this highly trained and dynamic person went into seclusion and a period of apprenticeship. First was his quite mysterious stay in Arabia (Gal 1:17), followed by the preliminary ministries at Tarsus in Cilicia (Acts 9:30) and Antioch ${ }^{1}$ (Acts 11:25, 26). Second, "under the blessing of God, and the wise training of Barnabas, he developed into a valuable worker."2

Patterns in Paul's Missionary Journeys

In his remarkable book, Missionary Methods, Rolland Allen has pointed out that Paul, in his evangelistic strategy, seems to have selected places which were centers of

'According to the $S D A B C$, as Paul did not visit his home province of Cilicia on the first journey, it is probable that the churches there were founded by him during his years at Tarsus following his conversion (see Acts 15:41; "Let's go again" [Acts 15: 36], $S D A B C, 6: 317$ ).

${ }^{2}$ White, The Acts of the Apostles, 170. 
Roman administration, Greek civilization, Jewish influence, and commercial importance. ${ }^{1}$ Walter Liefeld adds that these places were located on major trade routes oriented toward Rome. In these cities, almost invariably Paul commenced his labors in the synagogues (Acts $13: 5,14 ; 14: 1 ; 1: 1 ; 18: 4)$ among the Jews and God-fearing Gentiles who met with them in worship.

Although Paul's evangelistic strategy focused on conversion (Acts 26:18), his primary goal was to bring everyone to maturity in Christ (Col 1:28, 29). His responsibility was not discharged when he had initially presented the gospel and won converts. He also labored to move his converts toward maturity in Christ in anticipation of God's final assessment (cf. 1 Thess 2:19-20). ${ }^{2}$

Attempts have been made to fit Paul's strategy into distinct phases. ${ }^{3}$ However, from the discipleship perspective, the following logical elements seem to be obvious.

\section{Conversion and Church Planting}

Under Paul's ministry, people were converted and churches planted. In Cyprus the proconsul listened, and accepted Christ (Acts 13:12). In Pisidian Antioch, Paul's speech at the synagogue led many Gentiles to conversion (13:48). In Iconium, there was remarkable

\footnotetext{
'Rolland Allen, Missionary Methods: St. Paul's or Ours? (Grand Rapids, MI: Wm. B. Eerdmans Publishing Co., 1962), 10-17.

${ }^{2}$ David M. Hay, "Colossians," Abingdon New Testament Commentaries (Nashville: Abingdon Press, 2000), 77.

${ }^{3}$ See "The Pauline Cycle" described in David J. Hesselgrave, Planting Churches CrossCulturally: A Guide for Home and Foreign Missions (Grand Rapids, MI: Baker Book House, 1980), 58.
} 
success from the preaching of the gospel (14:2). The purely Gentile mission in Lystra and Derbe bore fruit as well (14:21).

Later writings, such as the letter to the Galatians, addressed to Psidian Antioch, Iconium, Lystra, and Derbe, indicate that several churches were formed only in his first missionary journey.

\section{Recruitment and Organization}

In Lystra, Iconium, and Antioch Paul appointed leaders and organized churches (Acts 14:21-23). He seems to have recommended a similar procedure to Titus (Titus 1:5). His first letter to the Thessalonians shows that there was already a recognized and active group of leaders (1 Thess 5:12,13).

Ellen White says that "churches were dully organized, and officers were appointed in each church, and proper order and system were established," even "when believers were but few in number." ${ }^{2}$ This shows that organization is essential for maintaining the spiritual life and growth of the church.

\section{Nurture and Relationships}

Through Paul's ministry, churches were strengthened and relationships continued (Acts $14: 21,22 ; 15: 36,41 ; 18: 23$ ). Paul not only raised up new churches; he also maintained an active concern for the continuing welfare of the churches he had planted. ${ }^{3}$

\footnotetext{
'White, The Acts of the Apostles, 185.

${ }^{2}$ Ibid., 186.

${ }^{3}$ Ibid., 186, 206, 207.
} 
Again and again he would go back to visit them, actually planning his missionary trips so that he could retrace his steps over much of the territory covered before in order to develop some deep roots, along with a sense of accountability.

He taught converts how to labor for the salvation of their fellow men, and this careful training was an important factor in Paul's success. ' When circumstances were such that he could not give the personal attention desired, he often arranged for others to take his place (Acts $17: 14 ; 19: 22)$. Such missions are alluded to repeatedly in his letters (1 Thess 3:2; Col 4:7-9; Phil 2:19, 20, 25-30). As already indicated, his purpose was to move the new believers to maturity $(\mathrm{Col} 1: 28,29)$.

Paul also kept in contact with new churches by his epistles and thereby helped solve their problems. New members needed development and correction in elementary doctrine and practical Christian living (1 Cor 5:1-10; 1 Thess 4:1-7; 1 Cor 8$). \mathrm{He}$ encouraged converts to develop spiritual gifts so they could build up the church and grow in spirituality (1 Cor 12), and he continually prayed for their spiritual progress (Phil 1:3-6; Eph 1:15-17; Col 1:3-6).

\section{Apprenticeship and Reproduction}

Paul, who had served an apprenticeship under Barnabas (Acts 16:1-6; 2 Tim 2:2), was conscious of the priority of spending time with persons training for leadership in the church. This is evident in his relationship with Timothy (Acts 16:1-6). He understood that this leadership was to replicate itself (2 Tim 2:2).

I'Ibid., 187. 
It is accurate to say that Paul did not train anyone for ministry. The training he did was training in ministry. For example, Paul chose Silas and added Timothy to their team, after he had spent time with Timothy in Lystra (Acts 16:1-6). The beginning of the first "we" passage in Acts suggests that Luke joined their missionary party at Troas (16:10). Luke characterizes Paul's travels as a group experience $(16: 6 ; 20: 4)$ and also mentions Gaius and Aristarchus as companions of Paul's team (19:29). Francis Badcock, in the Pauline Epistles, lists thirty-three associates in Ephesus alone. ${ }^{2}$

According to White, Paul's purpose was to help his associates gain "an experience that later enabled them to fill positions of responsibility." She adds that, "when separated from them, he still kept in touch with their work, and his letters to Timothy and to Titus are evidences of how deep was his desire for their success."

The ongoing challenge to continue making disciples is encapsulated in 2 Tim 2:2. These words remind us of Jesus' way of multiplying Himself. He invested in twelve; some of them discipled Barnabas; Barnabas trained Paul; Paul discipled Timothy. Now Timothy is challenged to do the same with "faithful men" who will be able "to teach others also." Following Jesus' method, Paul invested in individuals to make disciples. He too had his sights on the multitudes, but he knew that solid transmission of the faith would not occur

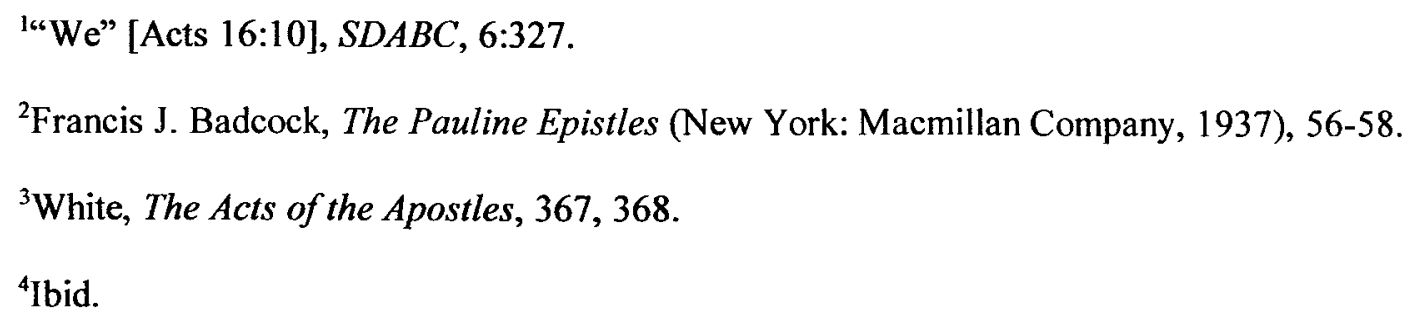


as readily through speaking to an audience. That is why he encouraged Timothy to equip a few "to teach others" (2 Tim 2:2).

\section{Paul's Personal Model}

In his book, The Disciple-Making Church, Bill Hull suggests that Paul presents the reproductive process which focuses on the individual in 1 Thess 1:5-8. ${ }^{1}$ From this text, three stages become obvious in Paul's relationship with the Thessalonians.

\section{Demonstration (vs. 5)}

Paul appeals to the Thessalonians' personal knowledge of the missionaries' behavior among them. Apprentices need to have behavior modeled before them so they can visualize the desired attitudes and behavior. ${ }^{2}$ Paul never feared to refer to his own behavior among his converts (1 Thess 2:1, 2, 5, 9-11).

He implied that not only the sermons but the lives of the evangelists preach the gospel, and the impact on the people's lives is the first step in the discipling process. He even used maternal and paternal images to convey his caring leadership among those he longed to "encourage, comfort, and urge" into Christian adulthood (2:7-12).

\section{Imitation (vs. 6)}

The genuine character of the religious experience of the Thessalonians is portrayed here. They have become imitators. The word imitate in the verse is mimeomai, from which

'Bill Hull, The Disciple-Making Church (Grand Rapids, MI: Fleming H. Revell, 1990), 137. ${ }^{2}$ Ibid. 
we get the word mimic. ${ }^{1}$ Paul is not afraid to say (cf. 1 Cor $4: 16$ ) because he also imitates Christ (1 Cor 11:1).

David J. William rightly affirms that "lifestyle is the only evidence that others have of our standing with God."2 Imitation means following the lifestyle of another. Even before any conversation had taken place, the enthusiasm, devotion, and willingness to suffer for Christ of the missionaries could have been seen and copied by the Thessalonians. Thus, imitation describes a fundamental part of discipling, learning from others and using them as guides (Phil 3:17). ${ }^{3}$

\section{Reproduction (vss. 7, 8)}

Now imitators become examples. Hendriksen and Kistemaker suggest a kind of circle here. "First the preacher/teacher gives an example of rejoicing amid suffering. Then the Thessalonians believe, welcome the word, become imitators. They in turn, carry the good news to others. ${ }^{, 4}$ One who is not an imitator cannot become an example or a model for imitation. To all believers in the two Roman provinces of Macedonia and Achaia, the Thessalonian converts had become an example of true missionaries."

${ }^{1}$ William Hendriksen and Simon J. Kistemaker, "Exposition of Thessalonians, the Pastoral and Hebrews," New Testament Commentary (Grand Rapids, MI: Baker Books, 1995), 52.

${ }^{2}$ David J. Williams, "1 and 2 Thessalonians," New International Biblical Commentary (Peabody, MA: Hendrickson Publishers, 1994), 30.

${ }^{3}$ Hull, 138.

${ }^{4}$ Hendriksen and Kistemaker, 53.

${ }^{5}$ Ibid. 
Therefore, we can agree with Hull that "reproduction takes place when the apprentice becomes a model. To become a model means the student has reached a point in his development where others can follow him." If the process of making disciples is to be complete, all new Christians should be trained to be active in evangelism themselves. The full-circle apprenticeship process requires time, love, discipline, and personal instruction. The added work of discipleship is well worth the investment, because the fruits remain and multiply.

\section{Paul's Corporate Model}

As already seen, Paul adopted the same goal and methodology in his ministry that Jesus modeled. Paul's version of the Great Commission is his personal mission statement in Col 1:28, 29. Paul's work at Ephesus provides an example of his commitment to evangelism, his discipling ministry, and his discipleship model.

\section{The Ephesian Church Strategy (Acts 19:1-21)}

When Paul arrived at Ephesus, he found a group of local converts who were ignorant of even the first principles of the Christian life (Acts 19:1-3). These disciples showed incomplete instruction and incomplete spiritual experience, corresponding with their lack of experience. ${ }^{2}$ From this it would seem unreasonable for Paul to hope that the provinces of Asia could be evangelized from the city of Ephesus. But he stayed in the city and began a staged program:

\footnotetext{
'Hull, 141.

${ }^{2 " C e r t a i n ~ d i s c i p l e s " ~[A c t s ~ 19: ~ 1], ~ S D A B C, ~ 6: 372 . ~}$
} 
1. Paul concentrated on the nominal nucleus, with the result that these people were soon rejoicing in a vital experience of Christ (Acts 19:4-7). ${ }^{1}$

2. With the cooperation of the nucleus, he followed his usual pattern (Acts 17:2; $18: 3,4)$. He went to the Jewish synagogue, where he preached over a period of three months, mainly on the Sabbath days, with the usual results-genuine conversions and bitter opposition (Acts 19:8).

3. Paul took the disciples with him to the school of Tyrannus, "continuing his public instructions"2 in an intensive (daily) program of evangelism which lasted for two years (Acts 19:9-10). Most commentators agree that the Western text adds to vs. 9 the note that Paul conducted this teaching between the hours of 11 a.m. and 4 p.m., the hottest time of the day when most Romans refrained from working (the siesta hours). If so, Paul would have used this building when Tyrannus's school would not have been in session. ${ }^{3}$

4. At this stage, the whole province of Asia, including the provincial capital, was evangelized, as occurred in Thessalonica (1 Thess 1:8) and Antioch of Pisidia (Acts 13:49). This could have happened in two ways. First, people from the country who flocked to the city on market days or for the numerous religion festivals would have

'White, The Acts of the Apostles, 282, 283.

${ }^{2}$ Ibid., 286.

${ }^{3}$ See Dennis Gaertner, "Acts," The College Press NIV Commentary (Joplin, MO: College Press Publishing, 1993), 301. 
dropped in to listen to Paul, and may have taken the gospel back to their townspeople. ${ }^{1}$ Perhaps among those who came was Philemon from Colossae (Phil 19) and Epaphras who took the gospel to Colossae (Col 1:7-8; 4:12-13). ${ }^{2}$

Second, Paul would also have been training his disciples and sending them out, from time to time, to the nearby towns. ${ }^{3}$ The possibility that Paul himself may also have gone out in mission must be qualified by the statement that some had not seen Paul's face (Col 2:1). The churches of Colossae, Laodice (including the other churches mentioned in $\operatorname{Rev} 2 ; 3$ ), and Hierapolis were probably established during the period of Acts $19-20 .^{4}$

\section{The Ephesian Discipling Ministry}

Having discussed the four stages of development of the Ephesian church, it is now appropriate to consider the features of Paul's ministry at Ephesus. In Acts 20:17-35 Paul is speaking solely to mature Christian leaders charged with the pastoral care of God's flock at Ephesus.

1. All aspects of truth had been expounded. Paul fearlessly had given the believers everything they needed for their spiritual development (vs. 20). Paul suggests that there could be pressures to hold back or suppress certain aspects of Christian truth (cf. vs. 27).

\footnotetext{
'Howard Peskett and Vinoth Ramachandra, The Message of Mission (Downers Grove, IL: InterVarsity Press, 2003), 229.

${ }^{2}$ Arthur G. Patzia, "Colossians, Ephesians, Philemon," New Testament Biblical Commentary (Peabody, MA: Hendrickson Publishers, 1995), 4.

${ }^{3}$ Simon J. Kistemaker, "Exposition of the Acts of the Apostles," New Testament Commentary (Grand Rapids, MI: Baker Books, 1990), 685.

${ }^{4}$ Ibid.
} 
Like Paul, the minister of the gospel will give his flock what they need, palatable or unpalatable, if it is spiritually nutritious. ${ }^{\prime}$

2. All places of opportunity and methods had been employed. "Publicly," Paul preached in the synagogue for the first three months of his stay in Ephesus, then he moved to the lecture hall of Tyrannus (Acts 19:8,9). The expression "from house to house" suggests more than the use of a few Christian homes in a locality, but rather a systematic approach to evangelistic preaching and pastoral instruction. ${ }^{2}$ With Paul, personal work did not take the place of public evangelism, but was an indispensable companion to it (vs. 20). ${ }^{3}$

3. All kinds of people had been instructed. Paul never tried to use his calling as an apostle to the Gentiles as an excuse not to preach to the Jews (vs. 21). He testified faithfully to both groups. He did not have favorites. There is no suggestion that he tried to cultivate a spiritual elite. He did not neglect Jews in spite of their repeated opposition (vs. 19). Paul was all things to all men so that he might win them for Christ (1 Cor 9:19-23). Here, he declared to the elders that he had completed his task and his conscience was clear (vs. 26).

4. All sources of opposition were identified. Paul had been a guardian to the churches he had formed. To the elders of Ephesus, whom Paul had just called overseers of the flock (vs. 28), he emphasized the vigilance that is to characterize those who guide and

"Profitable" [Acts 20:20], SDABC, 6:390.

${ }^{2}$ Roy Joslin, Urban Harvest: Biblical Perspectives on Christian Mission in the Inner Cities (Welwyn, England: Evangelical Press, 1982), 208.

${ }^{3}$ White, The Acts of the Apostles, 250, 296; idem, Testimonies, 6:321-323. 
pastor the church (vs. 31). Paul foresees dangers from outside the sheepfold of the church (vs. 29) as he had already alerted the Thessalonians (2 Thess 2:1-12) and Timothy (1 Tim 4:1-3;2 Tim 3:1-15). But he also warned of apostate influences coming from within (vs. 30), such as Demas (2 Tim 4:10), Hymenaeus, and Philetus (2 Tim 2:17).

5. All recommendations had been made. Paul's ministry was a temporary one, and now it was time to pass the baton to the next runner. The directions were given to those in leadership (2 Tim 2:2). Similar to his recommendations to the elders in the churches of Psidian Antioch, Iconium, Lystra, and Derbe (Acts14:23; 16:40), here he trusted the people he won for Christ to the care of elders, "to God, and to the word of His grace" to build them (vs.32).

\section{The Ephesian Discipleship Model}

Scholars commonly believe that the Ephesian epistle was sent to the church at Ephesus, the metropolis of the proconsulate of Asia, with the intention that it should also be sent to other churches in the area. ${ }^{1}$ John F. McArthur affirms that Eph 4:12-16 "in its most succint form is God's plan by which Christ produces church growth."" In this passage we are shown the progressive model, the purpose, and the power of God's divine pattern for the building and function of His church.

l“"Introduction," $S D A B C, 6: 993$.

${ }^{2} J$ ohn F. McArthur, "Ephesians," The McArthur New Testament Commentary (Chicago, IL: Moody Press, 1986), 151. 
Progression (4:12)

In the simplest possible terms Paul sets forth God's progressive plan for His church: equipping to service to building up.

Equipping. The word katartismos ("training," "preparing," "equipping") conveys the idea of a harmonious development in which all parts are brought to a condition of being able to perform according to their creative purpose ( $2 \operatorname{Tim} 3: 17) .{ }^{1}$ The word was often used as a medical term for the setting of bones, and the verb katartizo is used in Matt 4:21 for the mending of nets. ${ }^{2}$

McArthur has made a significant contribution to our understanding of this concept. He shows that "the evangelist's work is to bring men and women to understanding of the gospel of salvation, to lead them to receive Jesus as Lord and Savior," and that here "begins the equipping." The pastor-teacher's subsequent work, then, is to bring the saints to a condition of fitness for the discharge of their functions in the body. ${ }^{4}$ The highest attainment achievable by leaders is to reproduce their expertise in "ordinary" people and turn them into leaders.

'Patzia, 243.

2“Perfecting" [Eph 4:12], SDABC, 6:1023.

${ }^{3} \mathrm{McArthur,} 152$.

${ }^{4}$ Francis Foulkers, "The Letter of Paul to the Ephesians," Tyndale New Testament Commentaries (Grand Rapids, MI: Eerdmans Publishing Company, 1994), 128. 
Service. This training or equipping is for "ministry." The word here used (diakonia), which denotes menial service (Luke 10:40; 17:8; 22:26, 27; Acts 6:2). ${ }^{1}$ As clearly as in vs. 7 , it is thus implied that every Christian has a work of ministry, a spiritual task, and function in the body. They are to be aggressively involved in the work of the Lord (cf. 1 Cor 15:58; 1 Pet 2:5, 9; 4:10,11). All major point of emphasis here is that no matter how gifted, talented, and dedicated a pastor may be, his purpose in God's plan is not to try to meet all the church's needs himself but to equip the people given into his care to meet those needs.

Building up. The word oikodome (building up) literally refers to the building of a house. ${ }^{2}$ It is the spiritual edification and development of the church of which Paul is speaking here. The church is to be built up in both character and numbers. ${ }^{3}$ In other words, "the church is increased and built up, and its members edified, as each member uses his or her particular gifts as the Lord of the church ordains, and thus gives spiritual service to fellow-members and to the head. ${ }^{, 4}$

McArthur shows that even though the body is built up externally through evangelism as more believers are added, "the emphasis here is on its being built up

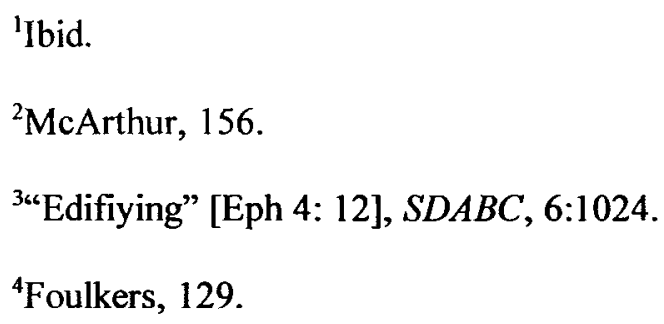


internally as all believers are nurtured to fruitful service through the word." ${ }^{11}$ Paul's exhortation to the Ephesian elders emphasizes this process (Acts 20:32).

Purpose (4:13-15a)

All three phases in vs. 12 have described the process going on in the life of the church. But the apostle could never think of a process without fixing his eyes on the goal. The end of the church's journey is described in three ways: (1) the unity of the faith; (2) the knowledge of the Son of God; (3) and maturity.

According to Hendriksen, the ideal of full Christian maturity is characterized in vs. 14 from its negative aspect, and positively in vs. 15 . The goal of Paul's ministry to believers was their maturity, as indicated by his labors to "present every man complete (teleios, mature) in Christ"2 (Col 1:28, 29; cf. Phil 3:14, 15).

Power (4:16)

From Christ alone, as head, the body derives its whole capacity for growth and activity (cf. Col 2:19). The text affirms, however, that every individual believer is to stay close to Jesus, faithfully using his spiritual gift in close contact with every believer he/she touches, and that through such commitment and ministry the Lord's power will flow for the building up of the body.

${ }^{1}$ McArthur, 156.

${ }^{2}$ Hendriksen, 201. 


\section{Ellen G. White's Approach to Discipleship}

After looking at some major principles of discipleship in the ministry of the Lord Jesus Christ and Paul, the focus shifts to the way Ellen White addressed the issue of making disciples. Ellen White is important to this study because Seventh-day Adventists consider her to be a genuine prophet.

For White, not all who profess to be church members or even workers are true disciples. ${ }^{1}$ Her writings suggest Jesus' definition of the true disciple: He or she is imbued with love for God and fellow men, ${ }^{2}$ is obedient to the will of Jesus, ${ }^{3}$ practices selfsacrifice, ${ }^{4}$ and bears fruit. ${ }^{5}$

It is appropriate to investigate her writings to discover what she said about discipleship when addressing pastors, church members, and new converts.

\section{The Pastor/Evangelist's Role in Discipleship}

Ellen White sees the role of the pastor and/or evangelist as very significant in establishing new believers in the church. ${ }^{6}$ It is the pastor's task to feed the flock with the

'Ellen G. White, The Ministry of Healing (Boise, ID: Pacific Press Publishing Association, 1942), 493; idem, The Desire of Ages, 644.

${ }^{2}$ White, Testimonies, 5:168; idem, The Desire of Ages, 678; idem, Gospel Workers (Washington, DC: Review and Herald Pub. Assn., 1915), 183.

${ }^{3}$ Ellen G. White, Medical Ministry (Boise, ID: Pacific Press Pub. Assn., 1963), 255.

${ }^{4}$ White, Testimonies, 5:222.

${ }^{5}$ Ibid., 348.

${ }^{6}$ Ellen G. White, Evangelism (Washington, DC: Review and Herald Publishing Association, 1974), 354-358. 
"thus saith the Lord" (Luke 22:32; John 21:15). If members, young and old, are not being fed, they are going to find food in other places. Besides, as far as White is concerned, the pastor's role includes training for ministry, planning work, and discipling in varied manners.

\section{Training for Ministry}

Not only does the Bible mandate training as the chief function of the pastor, but Ellen White does as well: "Let the minister devote more of his time to educating than to preaching. Let him teach the people how to give to others the knowledge they have received."1

She states emphatically that the pastor's first job is to train members, even before reaching unbelievers. "In laboring where there are already some in the faith, the minister should at first seek not so much to convert unbelievers, as to train the church members for acceptable cooperation." She also suggests that every church should be a training school for Christian workers with a wide variety of missionary curriculum. ${ }^{3}$

\section{'Ibid., 356.}

${ }^{2}$ White, Gospel Workers, 196.

${ }^{3}$ Ellen G. White, Christian Service (Washington, DC: Review and Herald Publishing Association, 1974), 59. 
White even intimates that any pastor who is performing ministry instead of training his members for ministry should be fired, ${ }^{1}$ for without this training in how to conduct the work of God, the work itself will almost certainly be a failure. ${ }^{2}$

\section{Planning Work}

Ellen White points out that the best help pastors can give the church "is not preaching or sermonizing, but planning work for them."3 This shows the degree to which importance is given to organized plans. She adds that "wise planning is needed to place each one in his proper sphere in the work," and that "well defined plans should be freely presented to all whom they may concern, and should be ascertained that they are understood."5

\section{Discipling with Different Approaches}

White recognizes that ministers have a part in assimilating new members. In order to establish and hold new converts, ministers are to visit new members often, ${ }^{6}$ to make Sabbath meeting a Bible class, ${ }^{7}$ and to establish new believers in the important branches of

${ }^{1}$ Ibid., 197, 198.

${ }^{2}$ White, Evangelism, 357.

${ }^{3}$ Ibid., 356.

${ }^{4}$ Ibid., 95.

${ }^{5}$ White, Christian Service, 94.

${ }^{6}$ White, Evangelism, 337.

${ }^{7}$ Ibid., 348. 
the work: health reform, spiritual gifts, systematic benevolence, and the great branches of missionary work. ${ }^{1}$

She recommends that teaching be a part of the assimilation process. To fix the truth distinctly in the disciple's mind, she underscores the importance of repeating points of truth in a second series of teaching, ${ }^{2}$ carried forward preferably by another teacher. ${ }^{3}$

The Church's Role in Discipleship

Not only do the ministers have responsibilities to the new converts, church members have a moral obligation as well. White affirms that "the church has a special responsibility laid upon her to attend to those who have earnestly followed the first rays of light they have received. ${ }^{, 4} \mathrm{~A}$ brief examination of her counsels clearly identifies the church's roles in discipleship.

\section{Watchful Attention and Encouragement}

White especially encourages the mature members to give "help, and sympathy and instruction for those who have conscientiously withdrawn from other churches for the truth's sake"s and are in need of extra support that the longtime Christian can help provide. The church member is also admonished to nurse those who are young in faith and

'Ibid., 343.

${ }^{2}$ Ibid, 334 .

${ }^{3}$ Ibid., 336.

${ }^{4}$ Ibid., 351 .

${ }^{5}$ Ibid. 
experience, to pray and read the Bible with them, and to "draw their minds away from temporal things to their eternal interests."1

\section{Coaching New Converts}

In this context White mentions the guardianship plan or what we would call sponsorship:

God is our Father, and He expects us to take an interest in the members of His household, not a casual interest, but a decided, continual interest.... If one member of Christ's household falls into temptation, the other members are to look after him with kindly interest.... Make yourself their friend. If they are poor and in need of food and clothing, minister to their temporal as well as their spiritual wants. Thus you will be a double blessing to them. ${ }^{2}$

Thus, she suggests a relational process in which a mentor, who is older in the faith, seeks to guide the mentoree into a deeper spiritual development by supporting, coaching, and praying.

\section{The New Convert's Role in Discipleship}

Ellen White points out that part of the responsibility for learning rests with the new member. There are many who make but little progress in their spiritual life because they are content with a superficial knowledge of God's word and make no effort to obtain greater light. ${ }^{3}$ An examination of her writings shows some basic counsels necessary in dealing with a new member's spiritual progress.

'Ibid., 352.

${ }^{2}$ White, Evangelism, 352, 353 .

${ }^{3}$ White, The Acts of the Apostles, 283. 


\section{Cultivate Spiritual Formation}

With the purpose of helping people move beyond surface living into spiritual depths, White urges new members to explore the world of the spiritual disciplines which are conversation with other Christians and meditation, ${ }^{1}$ service, ${ }^{2}$ continued searching of the Scriptures and devotional reading, ${ }^{3}$ submission, ${ }^{4}$ and simplicity. ${ }^{5}$

\section{Avoid General Dangers}

White cautions new members about being too dependent on humans instead of God. In this regard, these words were penned: "Let them feel that they are not to be carried and to lean for support on the church; but they are to have roots in themselves."

She also admonished new members against error and fanaticism which comes through false teachers who confuse their minds by wresting the Scripture and taking them out of their true context. ${ }^{7}$ Another danger closely related to the previous one is sensational religion. She points out that they must look for solid instruction on the reasons for their faith to help them obtain the necessary preparation against the heresies and errors that have the appearance of truth.

\footnotetext{
'White, Evangelism, 341, 342.

${ }^{2}$ Ibid., 354, 355.

${ }^{3}$ Ibid., 366, 367.

${ }^{4}$ Ibid., 340, 341.

${ }^{5}$ Ibid., 344.

${ }^{6}$ Ibid., 356.

${ }^{7}$ Ibid., 358.
} 
Finally, she warns that "nothing saps spirituality from the soul more quickly than to enclose in selfishness and self-caring."1 Thus it can be reasoned that those who are more actively employed in doing missionary activities are the best developed in spirituality and devotion.

\section{Discover and Use Spiritual Gifts}

According to White, the purpose in discipling new members is to equip productive church members. She said: "One Christ-loving, devoted member will do more good in a church than one hundred half-converted, unsanctified, self-sufficient workers."2

When her counsels to ministers on points on which to establish new believers are considered, it is seen how she regards spiritual gifts as an essential matter for a faithful education. ${ }^{3}$ She also recommends that every new member is to be given a job assignment in the church ${ }^{4}$ and that the minister and/or leaders of the church are responsible to see that new members are active. ${ }^{5}$ If new converts are given the proper instruction and the right job to do, it will help assimilate them.

White states that, "when souls are converted, set them to work at once. And as they labor according to their ability, they will grow stronger." On the other hand, she

${ }^{1}$ White, Evangelism, 357.

${ }^{2}$ White, Testimonies, 5:114.

${ }^{3}$ White, Evangelism, 343.

${ }^{4}$ White, Testimonies, 7:30.

${ }^{5}$ White, Evangelism, 345.

${ }^{6}$ Ibid., 355. 
cautions against moving too fast. "We must learn not to move too fast, and require too much of those who are newly converted to the truth."1 According to White, the main work for new members is to be trained for reaching the lost.

\section{New Member Discipling Model}

There is no way to overestimate the value of discipling all of God's people for ministry. In her book, The Desire of Ages, White comments on how Christ trained His disciples: "It was by personal contact and association that Jesus trained His disciples.... On His journeys through country and cities He took them with Him, that they might see how He taught the people. He linked their interest with His, and they united with Him in the work."2 Significant here are three important components to any successful discipling model: (1) nurture and instruction; (2) fellowship opportunities; and (3) assimilation through involvement.

\section{Nurture and Instruction}

After entry into baptism and church membership comes the nurture phase in the disciple's life. Regarding the convert care needed, White states emphatically: “Care should be exercised to educate young converts. They are not to be left to themselves .... Teach 1949), 131.

${ }^{1}$ Ellen G. White, Temperance (Mountain View, CA: Pacific Press Publishing Association,

${ }^{2}$ White, The Desire of Ages, 152. 
faithfully all that Christ has commanded. Everyone who receives Christ is to be trained to act some part in the great work to be accomplished in our world."

Whatever the method used (new member class, one-on-one, small groups), nurture could be conducted as a transitional program by selected mature members in charge of nursing new members. ${ }^{2}$ Pastors also should give attention to the past neglected areas of "health reform, spiritual gifts, systematic benevolence, and the great branches of the missionary work."

\section{Fellowship Opportunities}

New members will drop out if they do not find what their souls yearn for-an intimate loving Christian fellowship. White points to this love factor as the binding influence in Christian fellowship which bonds and cements new believers in the body of Christ. ${ }^{4}$ There is a keeping power in Christian fellowship and love, as is pointed out in her statement: "Believers are to associate together in Christian fellowship, regarding one another as brothers and sisters in the Lord. They are to love one another as Christ loved them."

\footnotetext{
'White, Evangelism, 367.

${ }^{2}$ Ibid., 352.

${ }^{3}$ Ibid., 343.

${ }^{4}$ White, Medical Ministry, 316.

${ }^{5}$ Ibid.
} 
Her concept of dynamic fellowship includes the early Adventist social meeting, which was a testimony service where testimonies were given about one's spiritual journey. "We then had a social meeting. Many testimonies were borne and many confessions made well wet down with tears. It was a profitable meeting."1

Burrill explains that these times of sharing the joys and sorrows of life were what enabled early Adventists to develop community among the believers as well as trained God's people to share their faith. ${ }^{2}$ White even indicates that this testimony and prayer meeting was practiced as a part of public evangelism when people were intellectually informed and relationally connected: "After the discourse there was a social meeting and many testimonies borne ... and I urged that those who were not fully on the Lord's side should make decisions that day." ${ }^{33}$ The point made here is that emphasis was on the relational element instead of the cognitive element present in preaching and teaching.

White also speaks about small groups ${ }^{4}$ (she uses the term "small companies") as a basis for ongoing nurture and care, to create community through Bible study and prayer. ${ }^{5}$

'Ellen G. White, Manuscript 29 (1887), 267; idem, Manuscript 83 (Aug. 12, 1893).

${ }^{2}$ Burrill, 187.

${ }^{3}$ Ellen G. White, quoted in D.A. Delafield, Ellen White in Europe, 1885-1887 (Washington, DC: Review and Herald, 1975), 308.

${ }^{4}$ White, Testimonies, 7:21, 22.

${ }^{5}$ Ibid., 195. 
She also advocates small groups as a basis for evangelism, ${ }^{1}$ as a ministering unit, ${ }^{2}$ and for intercessory prayer. ${ }^{3}$

There is another dimension to Christian fellowship-the social opportunity. Although fellowship had focused on the religious aspects, White also points to people's social needs ${ }^{4}$ and affirms that, "it is the proper cultivation of the social elements of our nature that brings us into sympathy with our brethren and affords us happiness in our efforts to bless others." Thus she recognizes the need of new members to be provided with the opportunity for kindly and helpful social events and relationships.

\section{Assimilation Through Involvement}

There is a significant gap between "joining" a church and "belonging" to it. New members need to know that they are wanted and needed, and the church can express care for a new person by providing the opportunity for participation and involvement.

According to White there is a relationship between spirituality and active participation. She affirms that "those who are most actively employed in doing with interested fidelity their work to win souls to Jesus Christ, are the best developed in spirituality and devotion." ${ }^{\prime 6}$ She argues that the reason some Christians never get beyond

'White, Evangelism, 389.

${ }^{2}$ Ellen G. White, Counsels on Health (Mountain View, CA: Pacific Press, 1951), 501.

${ }^{3}$ White, Evangelism, 111 .

${ }^{4}$ Ellen G. White, Education (Boise, ID: Pacific Press Pub. Assn., 1943), 41.

${ }^{5}$ Ellen G. White, Patriarchs and Prophets (Boise, ID: Pacific Press Pub. Assn., 1978), 541.

${ }^{6}$ White, Evangelism, 356. 
the $\mathrm{ABC} s$ of spiritual development is a lack of exercising their faith. ${ }^{1} \mathrm{~A}$ positive participation in personal ministry to others helps to confirm new members in the faith. ${ }^{2}$

First, however, new members should first receive training. This training should include personal ministries, ${ }^{4}$ helping new members discern personal spiritual gifts which can be matched to avenues of ministry and Christian service. It is interesting to note her statement: "They should be instructed that every department of the work of God should enlist their support and engage their interest." She adds: "The new believers are to be carefully instructed that they may have an intelligent knowledge of the various lines of work committed to the church of Christ."

The instruction is evident. New members are to be prepared to serve in different capacities, to minister to those in the church but even more, to reach those outside the church.

${ }^{1}$ Ibid., 355.

${ }^{2}$ Ibid.

${ }^{4}$ Ibid., 354.

${ }^{5}$ Ibid., 344.

${ }^{6}$ Ibid., 338. 


\section{CHAPTER III}

\section{CORPORATE DISCIPLESHIP MODELS}

This chapter explores three models employed for corporate discipleship. The first one reveals the priorities and practices of the early church, as described in the book of Acts. John Wesley's unique interlocking group system for personal spiritual improvement is the next model. The last one focuses on three currently employed strategies developed at Willow Creek Community Church, Saddleback Valley Community Church, and Pantego Bible Church.

\section{Early Apostolic Model}

According to Acts 2:42-47, the Early Church provided an excellent opportunity for growth in discipleship and created the environment needed for reproducing new generations of disciples.

\section{Background}

After that first great sermon by Peter on Pentecost, the practices of the early believers gave evidence of an important connection with Jesus' Great Commission. The result of the Church's first evangelistic message was impressive. Many of Peter's 
hearers 58 accepted his preaching, and about 3,000 new believers were added to the church (Acts 2:37-41).

The second chapter of Acts indicates that people were first taught, because they accepted Peter's message (Acts 2:41), then they were baptized into the body of Christ. ${ }^{1}$ Acts 2:42-47 describes the historical development of the first local church and "bridges the gap between the story of Pentecost and the next set of incidents in which the relation of the church to the Jewish authorities is depicted."2 The chapter takes the story beyond the Day of Pentecost and includes the believers' activities in the days that followed.

\section{Basic Strategy}

In the Jerusalem church, the apostles' priorities and practices, to which Christians intensively devoted themselves, became a way of life. Bill Hull affirms that "the actions of the first church confirm discipling was at its heart, and if we had nothing but Acts 2:42-47 to show us the way, it would be enough to make our churches discipling centers."3

\footnotetext{
${ }^{1}$ We should not regard this wonderful harvest as a result of the apostles' efforts in a single preaching. Ellen G. White affirms this in The Acts of the Apostles, 45: "During His life on this earth He had sown the seed of the truth and had watered it with His blood. The conversions that took place on the Day of Pentecost were the result of this sowing, the harvest of Christ's work revealing the power of His teaching."

${ }^{2}$ I. Howard Marshall, "The Acts of the Apostles," Tyndale New Testament Commentaries (Grand Rapids, MI: Eerdmans Publishing Company, 2001), 83.

${ }^{3}$ Hull, The Disciple Making Church, 64.
} 
Many authors refer to the discipleship practices of the early church. ${ }^{1}$ The practical guidebook to discipling, Turning the World Upside Down, by Carlos G. Martin, ${ }^{2}$ employed guidelines for action based on the book of Acts. Martin based his outline of church life of the early believers in Acts 2:42-47 to provide the framework for this suggested model which has three purposes and five functions. ${ }^{3}$

1. An Inward Purpose: To grow spiritually and to enjoy fellowship with the brethren. Two functions relate to this inward purpose. The function of nurture is seen in the early Christians' devotion to the apostles' teaching (Acts 2:42). In order to have a healthy spiritual development, all believers need the nourishment and training of Scripture. "In succeeding days that first instruction (Peter's sermon) would be supplemented by further lessons concerning Christ. All such instruction may be included in the term teaching of the apostles."

The second function is fellowship. "They devoted themselves... to the fellowship" (Acts 2:42). The basic meaning of koinonia (fellowship) is "sharing in, partaking in,

'John MacArthur identifies three distinguishing dimensions in the early church's practices: (1) The Spiritual Duties: It was a scriptural church, a fellowshipping church, a Christ-centered church, and a praying church (Acts 2:42); (2) The Spiritual Character: it was an awe-inspiring church, a miraculous church, a sharing church, and a joyful church (2:43a-47a); and (3) The Spiritual Impact: they were an attractive church, and a growing church (2:47b-47c) (Acts 1-12, The MacArthur New Testament Commentary [Chicago, IL: Moody Press, 1954], 79-92).

${ }^{2}$ Carlos G. Martin, Turning the World Upside Down (Nampa, ID: Pacific Press Publishing Association, 2000), 70, 71.

${ }^{3}$ See further explanations in George W. Peters, A Theology of Church Growth, (Grand Rapids, MI: Zondervan Publishing House, 1981), 184-239.

4"Doctrine" [Acts 2: 42], SDABC, 6:148. 
something or someone." "All the believers were together and had everything in common" (Acts $2: 44 ; 4: 32$ ). Fellowship also refers to the brotherhood that developed between the apostles and their converts because they were together on a regular basis. Their times of fellowship were not limited to the temple. They were also "breaking bread from house to house, and taking their meals together" (Acts 2:46). Breaking bread included both ordinary communal meals (vss. 42,46$)$ and the Lord's Supper $(1$ Cor $10: 16){ }^{2}$ There is no way to overestimate the value of the intimacy of fellowship with God and His people. We cannot function in isolation from one another if Christ's purpose for our lives is going to be accomplished.

2. An Upward Purpose: To glorify God. Luke next mentions the function of prayer. It may refer either to specific prayers or to times of prayer corresponding, perhaps, to the regular Jewish prayers. ${ }^{3}$ The converts, from the beginning, gathered together to pray as a new community (Acts $1: 14 ; 2: 42 ; 4: 24-31 ; 6: 1-7)$. They engaged in prayer, both private and corporate. What is significant here is that whether formal or informal, at fixed times or as occasion demanded, prayer "was integral to the whole forward thrust of the church, and in Luke's eyes at least, the vitality of the church was a measure of the reality of their prayers."4

\footnotetext{
${ }^{1}$ Wilkins, 275.

${ }^{2}$ Williams, 60 .

${ }^{3}$ Kistemaker, 111 .

${ }^{4}$ Williams, 60 .
} 
The fourth function is praise and worship. Praise characterized the early Christians' worship (Acts 2:47). According to Marshall, "this is one of the references in Acts to the Christians worshiping God in the sense of rendering thanks to Him."1 He also observes that the scarcity of such phrases reminds us that Christian gatherings were for instruction, fellowship, and prayer; nevertheless, worship was not absent."

When obedient believers become fully engaged in God's mandate to make disciples, their singing and praising are more vigorous and Spirit-filled "because they praise God from the depths of their commitment and experience."3

3. An Outward Purpose: To preach the gospel. Mission is the fifth important function of any church group. Martin emphasizes that, "though a group of individuals shares together worship, nurture, and community, they will not be a legitimate church if they remain focused inward." $\mathrm{A}$ final comment notes that the evangelistic activity of the church continued daily. If we are to gather the lost, we must give evangelism first priority in the process of making disciples. If one seeks a biblical measuring stick for effective evangelism, it would be God's daily adding to the body those being saved (Acts 2:47).

This brief glimpse of the purposes and functions of the early Christian church gives valuable insight into what makes a healthy, growing church. Proper devotion to the inward, upward, and outward purposes of the church by giving priority to the functions of

${ }^{1}$ Marshall, 85.

${ }^{2}$ Ibid., 86.

${ }^{3}$ Hull, 73.

${ }^{4}$ Martin, 73. 
nurture, fellowship, prayer, worship, and mission will produce a mature, reproductive congregation.

The model presented in Acts 2:42-47 views discipleship as the process of finding and winning the lost, folding them into a local church, and building them up in the faith. As mentioned in chapter 2 , the apostolic model of corporate discipleship suggests a process that moves people from believing, to bonding, to maturing.

\section{Wesley's Interlocking Group Model}

Historians have documented the impact of Wesley and Methodism upon the central values and directions of Western civilization and upon a significant branch of the Christian church. However Wesley's revolutionary system of constructing small interactive groups for personal spiritual improvement has been almost completely neglected. The heart of this system was a cell group of six to twelve people that Wesley named "the class meeting."

\section{Background}

By any standards, John Wesley was a remarkable man. His life (1703-1791) nearly spanned the eighteenth century. ${ }^{1}$ The report of the statistics of his life speaks for itself: 250,000 miles traveled on horseback, over 40,000 sermons preached during a span of sixty years, and more than 400 publications on nearly every conceivable topic. ${ }^{2}$ At his 120-121.

'John Pudney, John Wesley and His World (New York: Charles Scribner's Sons, 1978), 21.

${ }^{2}$ Richard P. Heitzenrater, The Elusive Mr. Wesley (Nashville, TN: Abingdon Press, 1984), 
death, he left behind 72,000 Methodists in Great Britain and Ireland and a young Methodist denomination in America of some 57,000 members. ${ }^{1}$

Howard A. Snyder, who has written a history of the Wesleyan influence on eighteenth-century England, has made reference to Wesley's roots. He notes that during Wesley's teaching days at Oxford University, he quickly became the leader of the "Holy Club,"2 "a society of very young and very earnest High Churchmen, with evangelistic views and a true desire to lead the lives of exemplary Christians." Its primary aim was the spiritual development of its members, and in the spiritual exercises of the Holy Club, Wesley's instructional technique was taking shape.

After his two frustrating years working as a missionary in Georgia and his experience of personal conversion at Aldersgate, he received an appeal from George Whitefield, an evangelist and former Oxford colleague, to help him with his successful open-air meetings in Bristol, with crowds of up to 10,000 miners. ${ }^{4}$

Mark Shaw was right in saying that Wesley's great idea was a simple one: "The church changes the world not by making converts but by making disciples. In order to preserve the fruit of revival and transform society, the church must move beyond making converts and give its attention to bringing converts to maturity."

'John S. Simon, John Wesley: The Last Phase (London: Epworth, 1934), 319.

${ }^{2}$ Howard A. Snyder, The Radical Wesley: Patterns for Church Renewal (Downers Grove, IL: InterVarsity Press, 1980), 14.

${ }^{3}$ Ibid.

${ }^{4}$ Ibid., 32, 33.

${ }^{5}$ Mark Shaw, 10 Great Ideas from Church History: A Decision-Maker's Guide to 
Early in his evangelistic ministry Wesley was convinced that much of his effort would be wasted unless a scheme was devised whereby his converts could be properly cared for. He said in 1743: "I am more and more convinced that the devil himself desires nothing more than that the people of any place should be half-awakened and then left to themselves to fall asleep again. Therefore I determine, by the grace of God, not to strike one stroke in any place where I cannot follow the blow."

With a burdened heart, Wesley underscored his commitment to discipleship when he wrote in 1763: "I was more convinced than ever that preaching like an apostle, without joining together those that are awakened and training them up in the ways of God, is only begetting children for the murderer (the devil).".2

For this purpose Wesley founded a highly developed organization. Some believe that this where his real genius lay. ${ }^{3}$ However, he was not so much an innovator as an adapter. ${ }^{4} \mathrm{He}$ immediately began to organize a number of societies and bands and when

Shaping Your Church (Downers Grove, IL: InterVarsity Press, 1990), 136.

'John Wesley, Journal, 3:71, 13 March 1743, quoted in A. Skevington Wood, The Burning Heart: John Wesley, Evangelist (Grand Rapids, MI: Eerdmans Publishing Company, 1967), 188.

${ }^{2}$ Ibid., 5:26, 25 August 1763.

${ }^{3}$ Wood, 186.

${ }^{4}$ Many diverse and disparate sources combined to form Wesley's group methodology: the small societies established in France by the Catholic nobleman Monsignor De Renty (1611-49); the Pietist Jackob Spenner's study groups, called Collegia Pietatis; and the cell groups system of the Moravians. 
Whitefield returned to America, Wesley was left totally in charge of the growing work. ${ }^{1}$ Thus the Wesleyan revival had began.

\section{Basic Strategy}

One of the basic features of Wesley's strategy was seen in the way he concluded a field preaching session. He seldom invited people to accept Christ and become Christians on the spot. ${ }^{2}$ Instead, he invited people to join a class. ${ }^{3}$ In the Methodist system of societies, classes, and bands, discipline and steady growth in grace were evident. The instructional components of the Methodist system are described by D. Michael Henderson.

\section{The Society: The Cognitive Mode}

In the chapter, "Wesley's System of Interlocking Model," Henderson reveals that the term "society" is nearly synonymous with the term "congregation," and that it was the umbrella group of the organization, in that all other related group came under its jurisdiction. ${ }^{4} \mathrm{He}$ also describes the primary function of the society as cognitive instruction. "It was the educational channel by which the doctrines of Methodism were presented to the target population." Then Henderson adds: "Those who had been drawn to the

'Snyder, 33.

${ }^{2}$ George Hunter III, To Spread the Power: Church Growth in the Wesleyan Spirit (Nashville, TN: Abingdon Press, 1987), 57.

${ }^{3}$ Ibid.

${ }^{4}$ D. Michael Henderson, John Wesley's Class Meeting: A Model for Making Disciples (Nappanee, IN: Evangel Publishing House, 1997), 83.

sIbid., 84. 
Methodists by curiosity or by field preaching or by the invitation of a friend were introduced to its particular teachings through society meetings."1

Another aspect of its resemblance to traditional congregations was the method used to present the message: lecture, preaching, and hymn singing, with little or no provision for personal response or feedback. ${ }^{2}$

These Methodist chapels had early morning sessions for members only, in order to teach the Bible and encourage Methodists to adjust to the working environment. They also met for evangelistic outreach on Sunday evenings, with worship and instruction on some practical aspect of Christian lifestyle. ${ }^{3}$ In addition to regular weekly meetings, there were several special celebrations matched to the cultural needs of the people. ${ }^{4}$

\section{Class Meetings: The Behavioral Mode}

Dwight L. Moody said: "The Methodist class meetings are the best institutions for training converts the world ever saw." "The class was a small group composed of twelve people, whose purpose was mutual confession of sin and accountability for growth in

I Ibid.

${ }^{2}$ Ibid.

3Ibid., 89.

${ }^{4}$ Ibid., 92.

5Ibid., 93. 
holiness. ${ }^{1}$ According to one author, it was, in fact, in the class meeting "where the great majority of conversions occurred.".2

It has been noted that there was no room here for lecturing or preaching but only personal experience; the emphasis was clearly on present and personal growth. ${ }^{3}$ Three categories of behaviors were specified: prohibitions, or things not to do; exhortations, or positive behaviors; and helpful practices to be maintained, which were known as the "means of grace."

\section{Band: The Affective Mode}

The next component of the Methodist system was the band. Again, Henderson explains that whereas "the society meetings aimed at cognitive instruction, the class meeting provided an environment for behavioral change, the band facilitated affective redirection." The bands were small cells divided by age, sex, and marital status, where people sought to improve their attitudes, emotions, feelings, intentions, and affections. ${ }^{6}$

In these "close conversation" meetings for soul-searching examination, no visitors were allowed. ${ }^{7}$ Significantly, the bands were voluntary cells where the members took the

${ }^{1}$ Shaw, 143.

${ }^{2}$ Snyder, 56.

${ }^{3}$ Henderson, 96.

${ }^{4}$ Ibid., 97.

${ }^{5}$ Ibid., 112.

${ }^{6}$ Snyder, 59-60.

${ }^{7}$ Ibid., 119. 
initiative to speak about their progress toward inward holiness; the leader only served to start the progress. ${ }^{1}$

\section{Penitent Band: The Rehabilitative Mode}

Another significant group in Wesley's system, the penitent band, was “designed for those who lacked the will power of personal discipline to live up to the behavioral demands of the class meeting but still had a desire to overcome their personal problems."2 Henderson notes that this group was very similar to Alcoholics Anonymous. ${ }^{3}$

\section{Selected Society: The Training Mode}

The last component of Wesley's method, the select society, was “an elite corps of those enthusiasts who had worked their way up through the ranks of class meetings, society, and band and were considered by both their personal leaders to be the standardbearers of the movement."4 In the select society is seen the recognition and training of leaders to show others the way the process should function. In fact, Henderson explains that Wesley's purpose in this group was not only to train its participants in the doctrines and methods of Methodism, but also to "hammer out strategies for the societies and have a major voice in the decision-making process."5

'Ibid., 118.

${ }^{2}$ Ibid., 125.

${ }^{3}$ Ibid., 126.

${ }^{4}$ Ibid., 121.

5Ibid., 123. 
Analysis

Wesley's genius was in borrowing, adapting, and combining diverse elements into a synthesis more dynamic than the sum of its parts. His system also provided a balance of the individual and the community. "Christian fellowship meant, not merely corporate worship, but watching over another in love, advising, exhorting, admonishing and praying with the brothers and sisters."1

Three specific points emerge from Wesley's system; these are important to any growing church: the unity and symmetry of his strategy, his leadership training emphasis, and his small group network.

1. Unity and Symmetry: According to Henderson, Wesley's convictions about the necessity of discipleship, his view that learning comes by doing the will of God, and that people's nature is perfected by participation in groups, not by acting as isolated individuals, enabled him to choose an appropriate strategy that was based on the following elements: ${ }^{2}$ (a) a hierarchy of interlocking groups; (b) behavioral change as the point of entry to the system, followed by affective, aspirational, and rehabilitative functions; (c) total participation and mobilization; (d) individualized care; (e) multiple accountability; and (f) separation of cognitive, affective, and behavioral functions. ${ }^{3}$

${ }^{1}$ Snyder, 148.

${ }^{2}$ Henderson, 139-140.

${ }^{3}$ William R. Yount, A Christian Teacher's Introduction to Educational Psychology: Created to Learn (Nashville, TN: Broadman and Holman Publishers, 1996), 249-253. 
This balanced strategy facilitated both effective instruction and ready supervision. The components seemed to work harmoniously despite the fact that they were applied under a fairly wide range of cultural settings. ${ }^{1}$

2. Leadership Training. Wesley was, from the beginning, a complete evangelist and his organization was geared to the after-care of his converts. Converts were trained to become soul-winners themselves. Many enlisted as lay preachers, others as class leaders, itinerants, and in other functions. In other words, the movement provided the context for the rise, training, and exercise of new forms of ministry and leadership.

We see powerful leadership values in the Wesleyan method: lay leadership; appointed leadership from among the most faithful Methodists; leaders recognized and trained in the select society; qualification by faithfulness; and local/regional leadership. ${ }^{2}$ Besides, Wesley mentored his trainees, for "he seldom traveled alone; he often took one or more helpers with him so they could observe and learn from him. He listened to his helpers preach and gave them criticism and advice."' His experience shows that effective ministry has little to do with formal education or ecclesiastical status and everything to do with spiritual growth, maturity, and structural flexibility. ${ }^{4}$

${ }^{1}$ Henderson, 145.

${ }^{2}$ Ibid., 147-155.

${ }^{3}$ Snyder, 163.

${ }^{4}$ Ibid. 
3. Small Group Network. Wesley's system shows that the church needs structures for community, discipline, and mission. Small groups provide a natural support context in a church that can easily become overwhelming and impersonal because of its size.

The value of small group structures for the vitality and growth of the church cannot be overestimated. This is not to suggest that small group structures should be directly patterned after the class or band meetings. But there is a need for something more than merely fellowship, study, or prayer groups. The Methodist system shows the need for covenant, discipline, and accountability within the group, and accountability of the group to the larger church body. ${ }^{1}$

\section{Contemporary Models}

Two important models employed for corporate discipleship have been considered: the Early Church and Wesley's interlocking groups system. Now is time to focus on three contemporary models of disciple-making churches: the Willow Creek Community Church, the Saddleback Valley Community Church, and the Pantego Bible Church.

\section{The Willow Creek Community Church}

This church has been described as the undisputed prototype of a new way of doing church and as the most influential church in North America and perhaps the world. ${ }^{2}$ It is also one of the most innovative churches in America because of its unique philosophy of ministry and its well-thought-out strategy for reaching the unchurched.

${ }^{1}$ Ibid.

${ }^{2}$ Shaw, 148, 149. 


\section{Background}

Bill Hybels is the founder and senior pastor of the Willow Creek Community Church in the northwest Chicago suburb of South Barrington, Illinois. In the book The Rediscovering Church, which describes the story of the conception and growth of Willow Creek, Lynne and Bill Hybels have made reference to Hybels' frustration with traditional churches and with what he perceived to be dead and meaningless ritual. ${ }^{1}$ Aware of the weak attendance in most mainline churches, Hybels decided to try a new approach to reach disenchanted Baby Boomers like himself: "a weekly seeker service that would provide a safe and important place where unchurched people could come to investigate Christianity further." ${ }^{2}$

In August of 1972, Bill Hybels began leading a group of thirty high-school students in the South Park Church in Park Ridge, Illinois. This youth group, "Son City," was designed to reach unchurched high-school-age young people for Christ. ${ }^{3}$ They used multimedia, contemporary music, skits, and messages that could help high-school students with their daily problems. In three years, attendance increased to more than a thousand young people. ${ }^{4}$

'Bill Hybels and Lynne Hybels, Rediscovering Church: The Story and Vision of Willow Creek Community Church (Grand Rapids, MI: Zondervan Publishing House, 1995), 32.

${ }^{2}$ Ibid., 41.

${ }^{3}$ G. A. Pritchard, Willow Creek Seeker Services: Evaluating a New Way of Doing Church (Grand Rapids, MI: Baker Books, 1996), 31.

${ }^{4}$ Joel Engelkemier, “A Church That Draws Thousands,” Ministry, May 1991, 14. 
Having found that they could program so as to interest youth, Hybels and several of his young helpers wondered whether they could also discover what would interest unchurched adults. In 1975 they spent a month conducting a house-to-house survey. They became aware of the most frequent complaints against churches: that church was irrelevant to daily life, that church services were lifeless and boring, and that churches were always asking for money. ${ }^{1}$

Drawing cues from what he learned from the survey, from his experience with the Son City youth group, and the influence of Dr. Bilezikian and Robert Schuller (Crystal Cathedral), ${ }^{2}$ Hybels and his staff developed a strategy for reaching and meeting the needs of what became the principal target of the Willow Creek Community Church, namely unchurched Harry and Mary. ${ }^{3}$

\section{Basic Strategy}

Employing marketing methods, Willow Creek places a great emphasis on defining a target audience, the individuals for whom it wants primarily to aim its services. To personalize and simplify the idea of a target audience, Hybels has given the typical target person a name-"unchurched Harry." ${ }^{\circ 4}$ For Willow Creek this generation (the Baby

${ }^{1}$ Ibid., 57, 58.

${ }^{2}$ For an understanding of the influence that Bilezikian and Schuller had on Hybels, see Hybels and Hybels, 40-50.

${ }^{3}$ Pritchard, 58.

${ }^{4}$ See a complete profile of "unchurched Harry and Mary" in Lee Strobel, Inside the Mind of Unchurched Harry and Mary: How to Reach Friends and Family Who Avoid the Church and God (Grand Rapids, MI: Zondervan Publishing House, 1993), 44-63. 
Boomers) is college educated, married with children, between 25 and 45 years old, and thinks negatively about institutions, especially the church. Their "needs include personal fulfillment, family, stress, loneliness, marriage problems, and purpose;" these became the basis for reshaping the gospel message in order to reach them. ${ }^{1}$

Key to Willow Creek's growth is a clear, significant mission statement and strategy. Mark Mittelberg, who is the evangelism director of Willow Creek, affirms that the church's mission is to turn irreligious people into fully devoted followers of Christ. $^{2} \mathrm{~A}$ central feature in the overall strategy of Willow Creek is the following seven-step strategy which is purposed to reach seekers with the gospel and to grow believers in the faith. ${ }^{3}$

1. Develop an authentic relationship with a nonbeliever. Every believer attending Willow Creek Community Church is strongly challenged to build a relationship of integrity with unchurched friends. Through their Becoming a Contagious Christians Training Course, they instruct and encourage believers to build relationships with irreligious people for the ultimate purpose of leading them to Christ.

2. Share a verbal witness. Once a relationship of integrity has been established, believers will have an opportunity to share their testimony with unchurched Harry and Mary, the church's target group. "This window of evangelistic opportunity needs a special

'Erich W. Baumgartner, "MegaChurches and What They Teach Us," in Adventist Mission in the $21^{\text {st }}$ Century, ed. Jon L. Dybdahl (Hagerstown, MD: Review and Herald Publishing Association, 1999), 152.

${ }^{2}$ Mark Mittelberg, Building a Contagious Church: Revolutionizing the Way We View and Do Evangelism (Grand Rapids, MI: Zondervan Publishing House, 2000), 25.

${ }^{3}$ Hybels and Hybels, 169. 
preparation to give an answer to everyone who asks you to give the reason for the hope that you have" (2 Pet 3:15), says Hybels. Believers are taught how to verbalize their testimony and trained to master several techniques for communicating their faith in a graphic and concise way.

3. Bring the seeker to a service designed especially for them. Most unchurched who hear about a believer's relationship with Christ will not immediately respond with a decision to establish a similar relationship. At this point believers need a place to bring their unchurched friends so that they will continue to be challenged in a relevant, creative, and contemporary way to consider the claims of Christ. Hybels calls these weekend messages "Christianity 101." These introductory-level messages come in a series and focus on the needs and interests of unchurched Harry and Mary.'

Using an approach similar to that of Billy Graham's crusades, these “seeker services" use contemporary Christian music, drama, multimedia, video, and discuss topics that are relevant to seekers-their marriages, their priorities, their finances, their parenting, and their quest for fulfillment from a biblical perspective.

4. Regularly attend a service for believers. Once someone has accepted Jesus as Savior and has been attending the weekend services for a time, he or she is encouraged to become involved in the midweek believer's service that provides believers with the opportunity to participate in corporate worship and listen to expository teaching designed to mature the believer.

${ }^{1}$ Ibid. 
In contrast to the weekend "seeker service," the "New Community" services are worship experiences for believers. This service is imperative for those who are committed to becoming fully devoted followers of Christ.

5. Join a small group. Believers who are involved in New Community are encouraged to take the next step in their Christian walk by participating in a small group that provides fellowship for the believer as well as a group for accountability, discipleship, encouragement, and support. It provides the optimal environment for incubating the maturing process. Hybels points out that "Willow Creek is not to be a church that offers small groups but a church of small groups." Their goal is to help every person who calls Willow Creek their home church to be connected to a little platoon of believers.

6. Discover, develop, and deploy spiritual gifts. At Willow Creek they start, not with a volunteer and a slot to fill, but with the person. They seek to find out what spiritual gifts God endowed the person with. Believers are encouraged to discover their spiritual gifts, develop them, and use them in some form of Christian service within the body of Christ through a network of ministry and seminars. The result: people serve with joy and effectiveness, with fulfillment and longevity, says Hybels. ${ }^{1}$

7. Stewardship of resources in a God-honoring way. At this point, new believers are educated in the area of money management and to recognize their individual responsibility to manage their money in a manner which glorifies God. It is important that every believer recognize that stewardship is a form of discipleship and that giving is a form of worship.

${ }^{1}$ Ibid., 170. 
Finally, another aspect of Willow Creek's strategy to turn irreligious people into fully devoted followers of Christ is the way used to know when they are fulfilling that objective. Hybels asks, "How can we measure the changing characteristics of a person who has been transformed by Christ?" His answer is a membership system known as Five Gs designed to evaluate new members' maturation:

1. Grace: If a person has accepted Christ's righteousness and has been baptized in a way to identify with Jesus.

2. Growth: If a person is deepening his/her faith through the spiritual disciplines (prayer, worship, Bible reading, etc).

3. Group: If a person participates in corporate gatherings as well as in a small group of believers to be encouraged and supported.

4. Gifts: If a person has identified at least one gift and has been placed in one ministry.

5. Good Stewardship: If a person is a faithful steward of the resources entrusted to him/her.'

Analysis

Several important concepts are commendable and positive in the strategy of Willow Creek. First of all, one of the vital characteristics of this church is being driven by a passion to see a lost person saved and folded in a loving community of believers. This commitment to effective evangelism and the emphasis that "lost people really matter to

${ }^{1}$ Ibid., 199, 200. 
God" drives Willow Creek to identify and respond to the personal and spiritual needs of people outside their worshiping community. Therefore, we can agree with G. A. Pritchard that Willow Creek's goal of seeking to understand their unchurched audience is the foundation of effective communication with people they are trying to reach. "Their aim is to understand Harry and Mary in order to help them comprehend the astonishing news that God has broken into history to reveal Himself."

Next, a Willow Creek strength is the ability to adapt to and employ the language of the culture they are seeking to reach. This adaptation is seen in the designed weekend seeker services which feature contemporary Christian music, drama, media, and basic biblical messages presented in terminology unchurched people can relate to.

The apostle Paul is the primary example of one who, in his efforts to communicate, identified with different audiences (1 Cor 9:19-22). This process should involve the adaptation of the message manner and emphasis, rather than content, and the adaptation of the messengers in their identification with people and their culture without losing their own identity. ${ }^{2}$

However, a danger in identifying with the audience appears when principles are compromised or the cultural context is elevated to such an extent that the content of the message is compromised. "Syncretism binds theology to culture in such a way that

${ }^{1}$ Pritchard, 191.

${ }^{2}$ Barry D. Oliver, "Can or Should Seventh-day Adventist Belief Be Adapted to Culture?" In Adventist Mission in the 21 st Century: The Joys and Challenges of Presenting Jesus to a Diverse World, ed. Jon Dybdahl (Hagerstown, MD: Review and Herald Publishing Association, 1999), 72-79. 
theology ceases to have any transcultural application." There is always the danger of crossing the line when relating Scripture to culture. When we are driven by culture rather than Scripture, the long-term result is usually unhealthy.

Another observation is that Willow Creek has a clear understanding of the major steps an unchurched person has to take to become a "fully devoted follower of Christ." Its goal is to bring the new believers along the path to full development and commitment to Christ, and to help them find their unique ministry through the development of their gifts and talents.

Understanding this process helps Willow Creek to develop its programs and ministry structures to facilitate this spiritual growth process. This insight might have important implications for Northeast Brazilian Adventist churches, which are known for great prebaptismal efforts but are less careful about the process of discipleship and spiritual growth after baptism.

Nevertheless, the main concern, common to almost all the critics of Willow Creek, is that seeker-sensitive churches compromise the gospel by tailoring their message to nonChristians, ${ }^{2}$ that the use of polished entertainment, feel-good sermons, and marketing techniques subtly alters the gospel that is being communicated. ${ }^{3}$ Pritchard observes that "the temptation of image, the use of psychology, the dilution of a biblical view of God,

${ }^{1}$ Ibid., 77.

${ }^{2}$ Michael G. Mandlin and Edward Gilbreath, "Selling out the House of God?" Christianity Today, July 18, 1994, 21-23.

${ }^{3}$ John McArthur, Ashamed of the Gospel (Wheaton, IL: Crossing Books, 1993), 45-88. 
and the loss of the centrality of truth are the direct consequences of a marketing method."1 He also points out that many Willow Creek conversions do not last because the majority of members do not attended the weekday services (Community 101), so the only theological teaching they receive is the weekend's user-friendly Christianity 101 and the basic salvation message. Besides, many individuals skip joining a small group and the steps of Willow Creek's strategy. ${ }^{2}$ Therefore, these potential weakness, if not corrected, lead to the danger of producing nominal members but not true disciples. ${ }^{3}$

The Purpose Driven Model

A second approach to building a corporate disciple making strategy is the Purpose Driven church model of Rick Warren, lived out in the Saddleback Valley Community Church in Southern California.

\section{Background}

Rick Warren, senior pastor and founder of the Saddleback Community Church Valley, in Orange County, Southern California, has the personal conviction that God has called him to be a pastor. He states that he has been greatly influenced by both Dr. W. A. Criswell, the renowned pastor of the largest Baptist church in the world, the First Baptist

'Pritchard, 244.

Ibid., 279.

${ }^{3}$ Ibid., 278. 
Church of Dallas, Texas, and the well-known church-growth specialist Donald McGavran. ${ }^{1}$

After graduating in 1979 from Southwestern Baptist Seminary in Fort Worth, Texas, Warren took a map of the United States and circled the four fast-growing areas that caught his attention: Seattle, San Francisco, San Diego, and Orange County. Then after having spent three months studying the census statistics of these four areas and doing demographic research, he felt that God, through particular providence, led him to Saddleback Valley (the fastest growing area in the fastest growing county in the United States in the 1970s) to raise up and plant a church there. ${ }^{2}$

In order to understand the mind-set of unchurched southern Californians, Warren declared that "he spent the first twelve weeks after moving to the Saddleback Valley going door-to-door talking to people,"3 and asking questions about the kind of churches they were looking for and the kind of services it would take to reach and meet their needs. ${ }^{4}$

${ }^{1}$ For more details about their influence in Warren's life, see Rick Warren, The Purpose Driven Church: Church Growth without Compromising Your Message and Mission (Grand Rapids, MI: Zondervan Publishing House, 1995), 25-30.

${ }^{2}$ Rick Warren, "New Churches for a New Generation: Church Planting to Reach Baby Boomers; A Case Study: The Saddleback Valley Community Church" (D.Min. diss. Fuller Theological Seminary, 1993, 7.

${ }^{3}$ Warren, The Purpose Driven Church, 39, 40.

${ }^{4}$ Warren, "New Churches for a New Generation, " 7 
After that he wrote an open letter to the community, mailing 15,000 letters out ten days before Easter. ${ }^{1}$ He had 205 people at his first service on Easter Sunday, $1980 .^{2}$

After sixteen years of meeting in schools, country clubs, warehouses, tents and even mental hospitals, Saddleback Valley Community Church moved into its own facility on September 17, $1995 .^{3}$

In June of 1995, Saddleback was recognized in a study by Liberty University, Lynchburg, Virginia, as the fastest-growing Baptist congregation in American history, growing from one family to over 11,000 attenders in sixteen years. ${ }^{4}$ Warren attributes his church growth to his philosophy of ministry, called "the Purpose Driven Church," which places a greater emphasis on building people than on erecting buildings.

The kind of church that Rick Warren had envisioned was one that would be limited to reaching the unchurched for Christ, people who for one reason or another did not attend any existing church. Thus, he never encouraged other believers to transfer their membership to his church; in fact he openly discouraged it. ${ }^{5}$

${ }^{1}$ Ibid.

${ }^{2}$ Ibid., 8.

${ }^{3}$ Alvin Reid, Introduction to Evangelism (Nashville, TN: Broadman and Holman Publishers, 1980), 291.

${ }^{4}$ Ibid., 292.

${ }^{5}$ Warren, The Purpose Driven Church, 39. 


\section{Basic Strategy}

Warren's strategy focuses on moving on from secondary issues, such as programs, finances, buildings, events, or seekers, to the primary issue: a biblical purpose-driven focus. "If you are helping a new church get started, your first task is to define a purpose. However, if you serve in an existing church that has plateaued absolutely nothing will revitalize a discouraged church faster than rediscovering its purpose."1

Warren argues that everything in the church should be done on purpose: assimilating new members, programing, education, small groups, staffing, structuring, preaching, budgeting, calendaring, and evaluating progress.

The slogan for Saddleback comes directly from the New Testament: "A great commitment to the great commandment (Matt 22:37-39) as the great commission (Matt 28:19-20) will grow a great church."2

Five key words are used to summarize the five purposes of the church in the Purpose Driven Church model:

1. Magnify: Celebrating God's presence in worship

2. Mission: Communicating God's word through evangelism

3. Membership: Incorporating God's family into fellowship

4. Maturity: Educating God's people through discipleship

${ }^{1}$ Ibid., 81.

2Ibid., 102. 
5. Ministry: Demonstrating God's love through service. ${ }^{1}$

These key words, representing five purposes, are incorporated into Saddleback's mission statement which reads as follows: "To bring people to Jesus and membership in His family, develop them in Christlike maturity, and equip them for their ministry in the church and life mission in the world, in order to magnify God's name."2

Warren clearly states that there is no single key to church health and church growth. "Health occurs when we intentionally balance all five of the New Testament purposes. Then growth is the result of health. This is the essence of being a purposedriven church." ${ }^{33}$ To help balance the five purposes, the Saddleback church is organized around two concepts: (1) Five Circles of Commitment and (2) The Life Development Process (see appendix B).

First, there is a recognition of the need to move people from where they are (low commitment/immaturity) to where they need to be (high commitment/maturity). Warren uses these five circles (the community, the crowd, the congregation, the committed, and the core) as an illustration to "who we do it with," or the people of different levels of maturity in the church. His goal is to move people from the community into the core. ${ }^{4}$

${ }^{1}$ Ibid., 109.

${ }^{2}$ Ibid.

${ }^{3}$ Rick Warren, "The Purpose Driven Church: A Contemporary Approach to Church Growth," in Evangelism for a Changing World, ed. by Timothy Beougher and Alvin Reid (Wheaton, IL: Harold Shaw Publishers, 1995), 23.

${ }^{4}$ Warren, The Purpose Driven Church, 131. 
Second, the Life Development Process illustrates "what we do" at Saddleback, says Warren. He uses a baseball diamond to visually explain the education and assimilation process of Saddleback's members. Each base represents a completed class and a deeper level of commitment. The goal of the church, according to the baseball diamond diagram, is not to get members on to first base but to get them around the bases into active ministry and evangelism. In order for this to be realized, members must complete sixteen hours of basic training and commit to the covenant at each base, ${ }^{1}$ because transformation does not happen by chance. This concept of Life Development establishes a disciple making or educational process that encourages people to act on what they learn and rewards them when they do.

In his Doctor of Ministry dissertation, Warren describes his ten-step strategy as follows:

1. Encounter: attracting the community through evangelism by having their felt needs met

2. Enlighten: introducing the crowd to the conversion process

3. Enlist: incorporating believers into the congregation through CLASS 101, "Discovering Church Membership"

4. Embrace: insuring that all member are loved and part of the family

5. Edify: developing members committed to the habits for spiritual growth through CLASS 201

'Ibid., 145. 
6. Examine: helping people find a personal ministry through a SHAPE interview after CLASS 301

7. Employ: assigning a job place for every member

8. Empower: commissioning and publicly affirming their life mission at a monthly service

9. Equip: providing on-the-job training and resources through SALT (Saddleback Advanced Leadership Training) to move people from Community to Core

10. Evaluate and Encourage: giving feedback to improve performance and recognition to reward results ${ }^{1}$

\section{Analysis}

The Purpose Driven Church model provides the opportunity to learn from a number of convictions and practices of corporate discipleship:

1. An intentional strategy. Warren and his assistants created and provided a safe place for people's journey of faith through a step-by-step plan for shaping and molding the lives of believers into the image of Jesus Christ. The church has programs and ministries in place that are appropriate for each of the four levels of spiritual development. At Saddleback it is not sufficient to receive Christ, be baptized, and join the church. Members must develop habits that lead to spiritual maturity, and find an appropriate ministry. The church also equips every member to win others to Christ and fulfill their life mission. From a quick survey of the requirements and curriculum of classes 101, 201, 301, and 401, it is

\footnotetext{
${ }^{1}$ Warren, New Churches for a New Generation, 236-240.
} 
evident that the Life Development Process is a creative way to fulfill Saddleback's ultimate goal of turning an audience into an army.

2. A balanced agenda. Even though Saddleback Church has a well-planned, carefully-thought-out plan for reaching the spiritually hungry with the gospel (their disciple-making does not begin with the believer but with the unbeliever), their evangelistic activities don't drive the total agenda of the church. While many churches find great difficulty in managing evangelism and edification simultaneously, they tend to emphasize one at the expense of the other. Saddleback maintains an evangelistic focus that is in balance with the other ministries and priorities of the church.

3. An educational program. Besides the sixteen hours of basic training and the commitment to the covenants at each base provided by the classes of the Life Development Process, Saddleback has its own way to determine a person's ministry through the SHAPE (spiritual gifts, heart, abilities, personality, and experiences), and the main training for the core: the SALT (Saddleback Advanced Leadership Training). This version of Wesley's Select Society is a monthly meeting with reports, testimonies, vision casting by the pastor, prayer, skill-building, and training.

A church that provides avenues for individuals to explore their faith in the context of a caring community, that provides gift-based ministry focused on the people, that encourages people to act on what they learned will grow. A church that designs an appropriate system to deploy gifted Christians in ministry, within the congregation and beyond to the community and world, will grow. 
The components of an intentional strategy, balanced evangelism-edification functions, and the educational program are three of the strong points of Saddleback's strategy for reaching and discipling unchurched for Christ. If any criticism must be made, it could be that this approach is not tied to a relational or transformational context of community. Since it does not take into account individual growth, could classes create a context for transformation? Could this approach with all its stages and different classes and ministries create a false sense of accomplishment in real discipleship? Overall, the Saddleback model is a worthwhile contribution to the study of corporate discipleship.

\section{The Connecting Model}

The last approach to building a corporate disciple-making strategy presented in this chapter is the connecting model of Randy Frazee, pastor of Pantego Bible Church in Arlington, Texas. The difference between this model and the others described in this dissertation lies in the fact that Pantego Church was a long-established and decadent church revisioned and revitalized through the discipleship approach.

\section{Background}

In his book, The Connecting Church, Randy Frazee affirms that when he became Pantego's senior pastor in 1990, the church had been experiencing a severe decline, losing over two-thirds of its membership.' From 1986 to 1989, the church declined from a

'Randy Frazee, The Connecting Church: Beyond Small Groups to Authentic Community (Grand Rapids, MI: Zondervan Publishing House, 2001), 19. 
membership of 1,200 to 400 , and lost eleven of the twelve staff members. ${ }^{1}$ From the time Frazee began "re-visioning and adopting of a new paradigm for ministry in order to revitalize his congregation, it grew to five times the size it had been in 1990."2

His first step to revitalize the Pantego Church was to discover the needs to be addressed. Discussions in staff meeting revealed that Frazee's central vehicle for discipleship and spiritual growth-the small group-was not working for the most motivated members of his church. Frazee was overwhelmed with this revelation. He found that "you can have a small group and not experience community, but you cannot have community apart from a small group experience." ${ }^{3} \mathrm{He}$ went home with the determination to design new structures that could help people simplify their church life, and develop more meaning, depth, purpose, and community. ${ }^{4}$

As Frazee began to pray and study American society and the effective place of community, he found that the three enemies that plagued American churches and society were individualism, isolationism, and consumerism. ${ }^{5} \mathrm{He}$ realized that, deep down, people want community but do not know how to get to it. Going back to Acts 2:42-47, the solution was to encourage community by helping people to find a common purpose, a

${ }^{1}$ Greg Ogden, course lecture, “Growing a Disciple-Making Congregation," Fuller Theological Seminary, Aug. 4-15, 2003.

${ }^{2}$ Ibid.

${ }^{3}$ Frazee, 22.

${ }^{4}$ Ibid., 37.

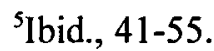


common place, and to share common possessions. These three components provide the basis for the strategy of the connecting model.

The common purposes, or seven functions of biblical community, are to be experimented in relational small gatherings, says Frazee. In order to avoid competing activities or functions at the church, he explains that these functions are not to be departments within the church, rather they are all to be applied in small communities in order to simplify the members' church life. To make it easier to remember, Frazee has conveniently formed an acronym: S E R V I C E.

1. Spiritual formation: encouraging group confession and personal goal setting

2. Evangelism: praying together to reach out to families

3. Reproduction: training leadership and reproducing another group

4. Volunteerism: involving in service and ministry

5. International missions: supporting one mission project

6. Care: helping people in crisis situations

7. Extending compassion: responding to social needs of the community ${ }^{1}$

In the same way, Frazee also deals with the basic characteristics shared by groups of people who experience true community around a common place:

1. Spontaneity: most of the gatherings are unplanned

2. Availability: willingness to help

3. Frequency: satisfaction in spending time together

${ }^{1}$ Ibid., 82,83 . 
4. Common meals: taking time to eat together

5. Geography: gathering based on neighborhoods and proximity ${ }^{1}$

His second step to revitalize his church was to define its mission as "to transform people through the work of the holy Spirit into fully developed followers of Jesus Christ."2 Then, in his third step, he stated the vision of Pantego Bible Church as "to reach the $74 \%$ unchurched by establishing at least one fully functioning Biblical Community in the 20 high school zones within a 10 mile radius of the church campus by the year $2010 . " 3$

\section{Basic Strategy}

Shortly after Frazee had defined the discipleship process, the mission, and the vision of Pantego Bible Church, he looked for a strategy to develop the transformation process in the lives of people (see appendix C). In his book, The Comeback Congregation, Frazee reveals that his first attempts to structure the church in a relational way came from C. Peter Wagner's three different-sized groups: Celebration, Congregation, and Cell. ${ }^{4}$ Then, from this concept he developed four distinct, integrated levels of involvement for the people of his church in order to involve them in Christian Life Profile, or the curriculum for systematic instruction and personal growth. ${ }^{5}$

${ }^{1}$ Ibid., 119-136.

${ }^{2}$ Ibid.

${ }^{3}$ Ogden, "Growing a Disciple-Making Congregation."

${ }^{4}$ Randy Frazee and Lyle E. Schuller, The Comeback Congregation: New Life for a Troubled Ministry (Nashville, TN: Abingdon, 1995), 94.

${ }^{5}$ Frazee, The Connecting Church, 92, 93. 
1. Worship Service: inspiring people to become fully developed followers of Christ. This task is accomplished through an intentional series of sermons called The Spiritual Formation Calendar, which focuses on spiritual formation themes, such as essential beliefs, practices, and virtues. ${ }^{1}$

2. Community Group: instructing people to become fully developed followers of Christ. Frazee considers this mid-size group, made up of about fifty individuals, to be the most efficient and effective way to achieve the biblical educational objectives. He believes that if the "small group is used for education, it minimizes the level of intimacy you can achieve and the opportunity for experiential involvement." ${ }^{2}$ One of the basic features of this group is that people who participate belong to the same neighborhood or area, and the curriculum is based on the core beliefs, practices, and virtues of the Christian life. ${ }^{3}$

3. Home Group: involving people in the seven functions of biblical community. According to Frazee, the fifty people who gathered in the mid-size Community Group now form five groups of ten people that meet in homes throughout the week (primarily on Sunday nights). Their primary goal is not to offer another Bible study but rather to encourage the practice of the seven purposes: spiritual formation, evangelism, reproduction, volunteerism, international mission, care, and extending compassion. ${ }^{4}$
${ }^{1}$ Ibid.
${ }^{2}$ lbid., 97.
${ }^{3}$ Ibid., 98.
${ }^{4}$ Ibid., 99. 
4. One Person: being introspective about his or her personal growth as a fully developed follower of Christ. Frazee believes that "the individual must never be viewed in isolation from the biblical community." "Therefore, the last level is the individual in his/her relationship with God and responsibilities as a member of the community.

In the chapter, "Implementing a Common Place," Frazee describes some of the special characteristics of the Connecting Church Infrastructure. "A zone pastor provides leadership for those who live within the boundaries of a particular area" and "his goal is to develop five to seven Community Groups that will meet on Sunday morning," ${ }^{2}$ says Frazee. The Community Groups are led by volunteers leaders with the goal of starting a new group if the size grows beyond fifty people. At the same time, these Community Group leaders also recruit five to seven leaders to establish the small group experience in the Home Group.

What is significant here is the leadership-in-training at all levels, from zone pastor to Home Group. "When the time comes to launch a new Home Group, Community Group, or Zone, the leadership is in place to make it happen,"3 says Frazee. Thus, a close look at the senior pastor's role reveals that his responsibility is to focus on visioning, preaching, and overseeing as "district pastor" who properly manages the zone pastors who, in turn, oversee the Community Groups leaders who are responsible for the Home Groups.

'Ibid., 101.

${ }^{2}$ Ibid., 164, 165.

${ }^{3}$ Ibid., 166. 


\section{Analysis}

One of the positive aspects of the Pantego Bible Church is the ability to recognize and implement the need for change. This church was established in the early 1950s, experienced a growth from 250 people to over 1,300 in 1985 , and a steady decline from 1986 to 1990 when service attendance decreased from 1,300 to $425 .^{1}$

Although everyone in the church, from the governing board to the person in the pew, knew that things had to change, it is significant that change requires a change agent. In his book, Create Your Own Future! Lyle Schaller writes, "One of the most highly visible methods of intervention in congregational life is the appearance of the skilled, respected, and effective leader who has a vision of a new and different tomorrow."2 This leader of change was one of their own Sunday school teachers-Randy Frazee, whose class grew to over 100 in attendance despite the church's decline. ${ }^{3}$

Essential to his success was his openness in recognizing the ineffectiveness of his small group system and his rethinking and reformulating of a new strategy. The result was a new way of doing church, a new leadership structure that provided a context in which Eph 4:12 could function, ${ }^{4}$ and a creative pathway for new member maturation.

'Frazee, The Comeback Congregation, 36, 37.

${ }^{2}$ Lyle E. Schaller, Create Your Own Future! (Nashville, TN: Abingdon Press, 1991), 24.

${ }^{3}$ Frazee, 46.

${ }^{4}$ William A. Beckham, The Second Reformation: Reshaping the Church for the $21^{\text {st }}$ Century (Houston, TX: Touch Publications, 1997), 189. 
Pantego Bible Church understands the importance of organic (infrastructural) growth. Its structure grew out of a need that already existed-like the experience in Acts 6-and it seems to be viewed as a support system, a means to an end rather than an end in itself. It is easy to recognize that Pantego Church balances small group structures (cells), large group structures (congregations), and very large assembly type structures (celebrations). ${ }^{1}$ John Wesley's classes and Willow Creek's small group network, along with a carefully developed array of ministries that enable people to get involved in using their spiritual gifts in ministry, are good examples of how structure serves growth.

From this brief survey of this model, it is evident that the four integrated levels of the Connecting Model, with their different functions at each level, based on the size of the gathering, are all united around the goal of making disciples. Interestingly, the funnel shape of the Intentional Assimilation Process suggests that the entry point flows from big worship to the small groups (like Wesley's Model). However, people can enter the fourlevel process from the top down (worship) or from the bottom up (neighborhood group) and immediately be connected to an intentional discipleship process with cognitive, affective, and behavioral functions.

In addition, the Connecting Church Infrastructure promotes leadership training and supervision by adopting a management structure similar to the one outlined by Moses' father-in-law, Jethro, in Exod 18. Facilitators of Community Groups provide oversight of Home Group leaders who in turn always have an apprentice.

'Pointer, 59-63. 


\section{CHAPTER IV}

\section{PERSONAL MODELS OF DISCIPLE-MAKING}

This chapter focuses on discipling as an intentional relationship in which we walk alongside other disciples in order to encourage, equip, and challenge one another in love to grow toward maturity in Christ. In the first part, five different models are analyzed in order to display a variety of approaches that can be used in NB. The chapter ends with a description of a discipleship model used for theology students at Northeast Brazil College.

Michael J. Wilkins declares that in the Gospels and Acts there are several different types of settings where Jesus and the church promoted the growth of disciples. ${ }^{1}$ These settings include one-on-one relationships, such as Jesus carried on with His followers and as existed between members of the early church (Barnabas and Paul). It also includes mentor relationships such as Jesus had with the Twelve and as were exhibited in the Early Church (Paul and his disciples). Finally, it includes small groups for ministry support such as Jesus had with the Twelve, and the missionary endeavors of Paul, Barnabas, Silas, Timothy, and others. ${ }^{2}$

'Wilkins, 279.

${ }^{2}$ Ibid., 280. 


\section{Family}

The greatest discipling potential lies in the family. To teach and encourage parents to discipline their children would go a long way toward creating a climate for discipleship in the church. Many men and women are defeated in church ministry because they are defeated at home. ${ }^{1}$ It is interesting that an important qualification for church leadership is the ability to manage the home (1 Tim 3; Titus 1$)$.

Gareth Icenogle, senior pastor of the First Presbyterian Church of Bethlehem, Philadelphia, and professor at Fuller Theological Seminary, stressed in his class the importance of Christian family as the primary environment for making disciples of Jesus. He showed the benefits and impacts of this model by arguing that "the way parents (mentor leaders) mediate love, grace, justice, and discipline will have a different impact on each child. Consistency in mediating grace will have a positive effect on the whole family."2

There are at least three ways in which the church can involve the family in its attempts at making disciples. First, the church must recognize that in God's plan Christian parents have the primary responsibility of passing the faith on to their children. ${ }^{3}$ Parents are to teach God's principles to their own children at home (Deut 6:5-7). Ellen White

${ }^{1}$ Ron Jenson and Jim Stevens, Dynamics of Church Growth (Grand Rapids, MI: Baker House, 1981), 164.

${ }^{2}$ Gareth Icenogle, course lecture, "Growing a Disciple-Making Congregation," Fuller Theological Seminary, Aug. 4-15, 2003.

${ }^{3}$ White, Christian Service, 206, 207. 
affirms that this work precedes that of the teacher and warns that a "woe rests upon parents who have not trained their children to be God-fearing, but allowed them to grow to manhood undisciplined and uncontrolled." The church should equip and encourage parents to provide their children with spiritual nurture. It will instruct parents in how to lead their children to Christ and into Christian maturity. ${ }^{2}$

Furthermore, the church can encourage family members to work together toward the end of sharing Christ with other families. ${ }^{3}$ People are more likely to become disciples and grow as Christians when their whole family unit comes to Christ. Finally, recognizing the importance of the family, churches that are serious about making disciples structure their programs to meet the needs of the family. They are family sensitive as they plan activities such as classes for all ages: children, program for youth, singles, parents, and elderly people to attract the entire family.

\section{One-on-one Mentoring}

Mentoring in the form of coaching has been quite popular in business and educational circles for the past few years. ${ }^{4}$ Leroy Eims comments on the tendency of organizations to rely on programs or materials to make disciples: "Disciples can not be

'Ellen G. White, Child Guidance (Hagerstown, MD: Review and Herald Publishing Association, 2000), 17-21.

${ }^{2}$ Ellen G. White, Fundamentals of Christian Education (Nashville, TN: Southern Publishing Association, 1923), 149-161.

${ }^{3}$ Ellen G. White, The Adventist Home (Washington, DC: Review and Herald Publishing Association, 1980), 32.

${ }^{4}$ Chip R. Bell, Managers as Mentors: Building Partnership for Learning (San Francisco: Berrett-Koehler Publishers, 1998), 6, 7. 
mass produced. We can not drop people into a program and see disciples emerge at the end of the production line. It takes time to make disciples. It takes individual, personal attention."1

Paul D. Stanley and J. Robert Clinton, in their book Connecting: The Mentoring Relationship You Need to Succeed in Life, define mentoring as "a relational experience in which one person empowers another by sharing God-given resources."2 This definition suggests that effective mentors are like friends in that their goal is to create a safe context for growth.

Allan Coppedge shows how the experience of Barnabas' illustrates this kind of disciple making in the Early Church. ${ }^{3}$ Barnabas, whose name means "son of encouragement" (Acts 4:36, 37), is described by Luke as "a good man, full of the Holy Spirit and full of faith" (Acts 11:24). After Saul's conversion, when others kept their distance from him, Barnabas not only saw potential in Saul (Paul), but also recommended him to the apostles by affirming the genuineness of his experience (Acts 9:26, 27).

Later, when the gospel spread to Antioch, Barnabas introduced Paul to ministry (Acts 11:25, 26). Then Paul, working under Barnabas' direction, began to develop the same commitment to make disciples. We also see this same pattern of Barnabas's one-onone mentoring when he determined to take the immature John Mark with him to Cyprus

${ }^{1}$ Eims, 45-46.

${ }^{2}$ Paul D. Stanley and J. Robert Clinton, Connecting: The Mentoring Relationships You Need to Succeed in Life (Colorado Springs, CO: NavPress, 1992), 42.

${ }^{3}$ Allan Coppedge, The Biblical Principles of Discipleship (Grand Rapids, MI: Francis Asbury Press, 1989), 141-156. 
(Acts 15:37-41) and readied him to serve in other capacities (Col 4:10; Phil 24; 2 Tim $4: 11$; 1 Pet $5: 13$ ) by investing his life in discipling over a period of years.

Stanley and Clinton classify the mentoring functions in three different groups. This table shows three types that comprise the intensive mentoring group and which seem to be more applicable to the evangelistic context of NB:

\section{TABLE 1}

\section{ONE-ON-ONE MENTORING}

\begin{tabular}{|c|c|}
\hline $\begin{array}{l}\text { Mentoring Type / } \\
\text { Functions }\end{array}$ & Central Thrust of Empowerment \\
\hline \multicolumn{2}{|l|}{ Intensive } \\
\hline 1. Discipler & Enablement in the basics of following Christ. \\
\hline 2. Spiritual Guide & $\begin{array}{l}\text { Accountability, direction, and insight for questions, commitments, } \\
\text { and decisions affecting spirituality and maturity. }\end{array}$ \\
\hline 3. Coach & Motivation, skills, and application needed to meet a task. \\
\hline \multicolumn{2}{|l|}{ Occasional } \\
\hline 4. Counselor & $\begin{array}{l}\text { Timely advice and correct perspectives on viewing self, others, } \\
\text { circumstances, and ministry. }\end{array}$ \\
\hline 5. Teacher & Knowledge and understanding for a particular subject. \\
\hline 6. Sponsor & $\begin{array}{l}\text { Carrier guidance and protection as leader moves within an } \\
\text { organization }\end{array}$ \\
\hline \multicolumn{2}{|l|}{ Passive } \\
\hline 7. Model Contemporary & $\begin{array}{l}\text { A living, personal model for life, ministry, or profession who is not } \\
\text { only an example but also inspires emulation. }\end{array}$ \\
\hline 8. Historical & $\begin{array}{l}\text { A past life that teaches dynamic principles and values for life, } \\
\text { ministry, and/or profession. }\end{array}$ \\
\hline
\end{tabular}




\section{Discipler}

Here a discipler-mentor teaches and enables a mentoree in the basics of following Christ. ${ }^{1}$ In order to know and follow Jesus, a disciple needs to establish habits (devotion, Bible reading, service, etc.) that will affect his or her character and destiny. And habits are developed through a combination of knowledge, skill, and desire. ${ }^{2}$

This mentoring function has a close similarity with the discipling approach used in personal evangelism among SDA churches. What is significant here is that SDA churches in NBUM tend to rely on a church member to initiate contact and cultivation, which means establishing a friendship and seed-planting. This implies sharing biblical truths, making appeals for a decision, harvesting, and taking the new believers under their wing. This relationship should last until the new believer moves from a dependent stage to a maturing stage in which the mentoree has important growth habits for a disciple, such as devotion, stewardship, service, and obedience.

\section{Spiritual Guide}

Stanley and Clinton define a spiritual guide as "a godly, mature follower of Christ who shares knowledge, skills, and basic philosophy on what it means to increasingly realize Christlikeness in all areas of life." Although there is some overlap between this type of mentoring and discipling, the second one deals with the basic issues of

${ }^{1}$ Stanley and Clinton, 51.

${ }^{2}$ Ibid.

${ }^{3}$ Ibid., 65. 
commitment-getting a "jump start"on following Jesus, ${ }^{1}$ while a spiritual guide moves new believers to the interdependence with the body of Christ for greater growth and ministry. This can be accomplished through providing accountability and insights concerning questions, commitments, and directions affecting spirituality and maturity. ${ }^{2}$

Barna recognizes that among the churches he has studied, the toughest job is training people to be effective mentors, "knowing how to integrate someone into the flow when he or she is not a skilled mentor, and preventing the mentoring process from becoming strictly a fellowship effort." ${ }^{33}$ Rainer observes that in assigning relationships, the discipler and disciple should be free to choose each other, instead of attempting to create an artificial relationship. ${ }^{4} \mathrm{He}$ adds that this is one of the best discipleship approaches, although the primary problem is "finding enough committed disciplers who are willing to give the hours necessary to such a labor-intensive responsibility.".5

Some SDA churches in NB utilize this one-on-one approach, linking up each new believer with a "spiritual friend" to help guide the new Christian in the early days of his or her spiritual life. Because oftentimes the actual procedure used to pair up the new believer with a more mature believer seems to let new converts "fall through the cracks," an option

'Ibid.

${ }^{2}$ Ibid.

${ }^{3}$ Barna, 124.

${ }^{4}$ Thom Rainer, Effective Evangelistic Churches: Successful Churches Reveal What Works and What Doesn't (Nashville, TN: Broadman and Holman Publishers, 1996), 180.

${ }^{5}$ Ibid. 
would be to have an officer or a trained member coordinate this task by selecting potential disciplers and thus assign a more mature and connected believer to each new Christian.

Another approach would be to match new converts with disciplers who share certain characteristics such as age, marital status, occupation, and hobbies. Detailed information kept on file for each trained discipler is essential for a successful discipling relationship and a lasting friendship.

\section{Coach}

Coaching is a relational process in which a mentor, who knows how to do something well, imparts those skills to a mentoree who wants to learn them.' Coaching has its origins in the concept of apprenticeship, where an older, more experienced individual passed down his knowledge of how the task was done and how to operate in the commercial world. $^{2}$

Eph 4:12 challenges church leaders to equip the saints for the work of ministry. Ministry coaches equip God's people by helping them develop their God-given potential so that they grow personally and make a valuable contributions to the kingdom of God. However, good coaches keep a balance between personal growth and ministry contribution. Too much emphasis on personal growth can cause the team to get spiritually fat. Too much emphasis on ministry leads to burn out. ${ }^{3}$

'Stanley and Clinton, 79.

${ }^{2}$ John Whitmore, Coaching for Performance (London: Nicholas Brealey Publishing, 1996), 84.

${ }^{3}$ Steven L. Ogne and Thomas P. Nebel, Empowering Leaders Through Coaching 
The way in which the SDA churches in NB integrate coaching into their process is usually based on training seminars. This method is good for orientation, vision casting, team building, but is not the most effective means to mobilize and equip new leaders. Other effective training systems could be developed, such as the apprentice strategy, the leadership group, and individual mentoring.

Robert E. Logan and Sherilyn Carlton suggest the five Rs of the coaching process to help disciples release their full potential: (1) Relate by establishing coaching relationship and agenda; (2) Reflect by discovering and exploring key issues; (3) Refocus by determining priorities and action steps; (4) Resource support and encouragement; and (5) Review by evaluating, celebrating, and revising plans. ${ }^{1}$

\section{Triads}

In his book, Cultivating a Life for God, Neil Cole suggests that the best context for disciple making, one that emphasizes relationship, multiplication, and transformation, is the triad, "made up of two to three people, all of the same gender, who meet weekly for personal accountability in the areas of their spiritual growth and development. ${ }^{33} \mathrm{He}$

(Nashville, TN: ChurchSmart Resources, 1995), 2.

${ }^{1}$ Robert E. Logan and Sherilyn Carlton, Coaching 101: Discover the Power of Coaching (St. Charles, IL: ChurchSmart Resources, 2003), 29.

${ }^{2}$ This model originated with Greg Ogden who proposed a threesome as the ideal size for disciple making group. See Ogden, 145.

${ }^{3}$ Neil Cole, Cultivating a Life for God: Multiplying Disciples through Life Transformation Groups (Carol Stream, IL: ChurchSmart Resources, 1999), 63. 
suggests that the triads or the Life Transformation Groups (LTG) "should not grow beyond three but multiply into two groups of two rather than a single group of four."1

Ogden outlines some reasons why a triad is superior to the one-on-one model for making disciples. First, the one-on-one sets up a teacher-student dynamic. When a third person is added, the dynamic shifts to a group process, where the disciple can more naturally make his or her contribution. Second, a triad shifts the model from hierarchical to relational. Third, by adding a third person who has been equipped to disciple others, the multiplication process is geometrically increased. ${ }^{2}$

The parallel is noteworthy between the triads and the Methodist system of "Bands." Both are based on soul-searching examination, on homogeneous composition, and on affective redirection rather than at cognitive instruction. It is significant that there is no curriculum or training needed for the LTG. Its "accountability consists of three essential disciplines for personal spiritual growth-a steady diet of Scripture, confession of sin, and prayer for others who need Christ." ${ }^{\text {3 }}$ Cole also identifies five benefits and biblical reasons for participating in the LTG: ${ }^{4}$

1. Community (Eccl 4:9-12): Life change occurs in relationship with others.

2. Accountability (1 Tim 5:19): A group of two to three has a greater degree of strength in accountability.

${ }^{1}$ Ibid.

${ }^{2}$ Ogden, Discipleship Essentials, 10, 11.

${ }^{3}$ Cole, 63 .

${ }^{4}$ Ibid., 49-52. 
3. Confidentiality (Matt 18:15-17): Is much easier to control in a context of two to three.

4. Flexibility (Matt 18:20): With two or three there is a better opportunity to coordinate schedules.

5. Reproducibility: A group of two to three can multiply much easier than a small cell group of ten.

\section{Small Groups}

Gary E. Tangeman defines a small group as "a voluntary gathering of three to twelve people, regularly meeting together with the shared goal of edification, fellowship and outreach."1 David Cox affirms that small groups have a "vital role to play in helping us grow and leading others to discipleship, simply because of the nature of what they do."2 He explains that the reason for such effectivity is based on the presence of the following elements: Bible study is relational, and everyone is involved in it; prayer is natural, spontaneous, and personal; worship is meaningful to individuals and the group; spiritual gifts are readily identified, developed, and used; pastoral care is shared; nurture takes place at different levels in different groups; and witness takes place informally. ${ }^{3}$

${ }^{1}$ Gary E. Tangeman, The Disciple Making Church in the $21^{\text {st }}$ Century (Fort Washington, PA: Christian Literature Crusade, 1996), 295.

${ }^{2}$ David Cox, Think Big, Think Small Groups (Watford, England: Department of Personal Ministries of the South England Conference of the Seventh-day Adventists, 1998), 40.

${ }^{3}$ Ibid., 40-48. 
These structures are not limited by facilities or finances; they are geographically expandable; they encourage vital personal relationships; they encourage lay ministries, facilitate leadership training, and promote the assimilation process. ${ }^{1}$ Also, these primary groups and basic structure provide the church with a face-to-face context for personal and intimate relationship and lifestyle formation. ${ }^{2}$

A variety of small groups can be developed to accommodate the many needs and levels of maturity of attenders of a local church. Groups also can be formed around areas of affinity such as marital status, age, ministry, task, personal need, life stage, and so forth.

Carl F. George presents a model similar to the one used in the South America Division. Based on Jethro's court system (Exod 18:1, 11), he suggests a church's system in which a cell group of ten I's (individuals) contains an X (the facilitating leader), an Xa (the apprentice leader), and several people with the given symbols: $\mathrm{H}$ (the hospitality host), G's (growing disciples), S's (seekers), EGR (an extra care required person), and the $\mathrm{L}$ (the coach of the X's, who occasionally visits to observe). ${ }^{3}$

This structure (see appendix D) results in much apprentice development with an X nurturing an Xa until that Xa reaches the level of practice required to be an effective $\mathrm{X}$, as well as in more personalized, spontaneous assimilation for the growing disciples.

'Aubrey Malphurs, Pouring New Wine into Old Skins: How to Change a Church without Destroying It (Grand Rapids, MI: Baker Books, 1993), 180.

${ }^{2}$ Ibid.

${ }^{3}$ Carl F. George, Prepare Your Church for the Future (Grand Rapids, MI: Fleming H. Revell, 1992), 144-148. 
As has already been seen, the small groups provide solutions to various problems of ministry. However, because people are involved in a small group does not necessarily mean that they are in the discipleship track. Barna's research shows that most small groups do well with fellowship but falter when it comes to facilitating transformation. ${ }^{1} \mathrm{He}$ emphasizes that "unless there is ample training for facilitation, a tight accountability process, strong relational connections, and a purposeful selection of material to cover, the small groups will fail to produce disciples." Eddie Gibbs says that "there can be an overemphasis on relational building to the point that there is an unhealthy shift of focus from the message to the personality and experience of the witness."

\section{Ministry Team}

The ministry team (church focused) or mission group (focused on a need in the world) is a small group (3-12) of people who covenant together to care for each other while exercising their spiritual gifts to minister to a need for which they mutually care. ${ }^{4}$ Katzenbach and Smith define a team as a "small number of people with complementary skills who are committed to a common purpose, performance goals, and approach for which they hold themselves mutually accountable." Also "they have a sharp mission,

'Barna, 54, 55.

${ }^{2}$ Ibid., 121.

${ }^{3}$ Gibbs, 203.

${ }^{4}$ Ogden, "Growing a Disciple- Making Congregation."

${ }^{5}$ Jon R. Katzenbach and Douglas K. Smith, The Wisdom of Teams, quoted in George Cladis, Leading the Team-Based Church (San Francisco: Jossey-Bass Publishers, 1999), 95. 
collaborate by combining their skills, gifts, and resources toward a meaningful (measurable) goal."1 Paul's metaphor of the spiritual gifts in terms of the human body is applicable to team ministry (1 Cor 12-14): diverse, with many different kinds of parts that function interdependently. In his view the body of Christ has no part more important than another part. Each is gifted for the common good of the whole team. Each contribution is valued and needed.

There are at least four basic elements in a ministry team. First, a mutually agreed upon written covenant between all members includes a statement of purpose or mission, activities, or procedures to carry out the covenant, and roles clearly defined for each person. Second, the team is expected to accomplish the objectives they set, not just pass them on to others. Third, people are invited to join the team based upon a sense of call and gifting that values and facilitates the contribution of all the team members. Fourth, the group provides accountability to each other and to the covenant.

As noted in chapter 2, the involvement of new members in meaningful service by the church and community helps them to grow in their discipleship process. The opportunity to serve should occur even before formal membership. This point of view is supported by Schmidt, who affirms that "ministry is the domain of all those who are on the journey, no matter if they are near or far." Their involvement in the process of conversion can make an everlasting difference in those surrounding them with the effect of "one

${ }^{1}$ Ibid.

${ }^{2}$ Eduard E. Schmidt, course lecture, "Equipping and Motivating Church Members for Ministry," Andrews University, March 2-14, 2003. 
sinner leading another to the cross of Christ, one beggar showing another the way to the bread of life."'

\section{Classes}

Ongoing classes are an important tool in nurturing and discipling as well as in placing people into ministry. Often these classes are taught by the pastor, though they may be just as effective (if not more so) when taught by a layperson in the church. Some churches utilize the educational system of the Sabbath School to place new Christians in follow-up and discipleship groups with people of similar age. In other churches, prospects are placed in a baptismal class that meets on Sunday night where they receive teaching based on spiritual growth or basic doctrine.

Although these subjects are vitally important, the membership class and the new believers class should not only be responsible for the spiritual nurture, but also introduce new and prospective members to the various avenues of personal ministry and help them find a ministry to become engaged in service. They also should answer the following question: What is the mission of the church? What are the responsibilities of membership? What is the vision and strategy of this church? How is the church organized? How can I get involved in ministry?

There are many ways to establish discipleship classes. Perhaps the idea of involving new members in a program of thirty-two hours of basic training, divided in four bases or modules, with a written covenant to be signed and to which people would commit at each

'Ibid. 
base before moving ahead, would be applicable in the NB territory. ${ }^{3}$ These four modules with their specific curriculum are explained in chapter 5.

\section{The Model for Seminarians at NBC}

Training for religious vocation is an educational process in which an experienced coach-teacher seeks to inspire and equip a student-mentoree in a given setting of ministry with motivation, perspective, and skills to effect changes in the student as a minister, as he or she does the work of ministry. Theological education, like many other educational programs, has four distinct aspects: the classroom with academic instruction, the library with supplementary study, field experience with its practical aspects, and the informal discussion and personal reflection. ${ }^{2}$

As a professor and evangelist at $\mathrm{NBC}$, my greatest challenge was to find out what kind of personal disciple-making approach would be more suitable to the threefold objectives: (1) Meet the causes of discipleship deficits by supplying seminarians with a model that includes a proper disciple-making view, which places strong emphasis upon the equipping role of pastors so that their ministry is multiplied; (2) Provide them with a pathway to maturity, which can be defined as a level of achievement that will take them from dependence toward autonomy, from limited to skilled abilities, from insecurity to competence in ministry, from superficiality to spiritual formation, from the need of discipline to discipline in work, finances, and study; and (3) Provide a mentoring

'See Warren, The Purpose Driven Church, 319.

${ }^{2} \mathrm{~J}$. Christy Wilson, Ministers in Training: A Review of Field Work Procedures in Theological Education (Princeton, NJ: Princeton Theological Seminary, 1957), 3. 
experience that will be so valued by students that they will seek other mentors in the future to help them pursue lifelong learning.

As long ago as 1929, the General Conference of SDAs mandated an internship plan to follow their basic ministerial training. ${ }^{1}$ This would agree with what Ellen White said about young pastors associating with older, experienced ministers. ${ }^{2}$ The recent Handbook of Seventh-day Adventist Ministerial and Theological Education reiterates the need for an internship. ${ }^{3}$

At NBC the chosen approach was in the form of intensive mentoring with a coach. Coaching is a relational process in which a mentor, who knows how to do something well, imparts those skills to a mentoree who wants to learn them. ${ }^{4}$ There is some overlap with the teacher-mentor, who imparts knowledge and understanding in a specific area. However, the emphasis is on imparting skills and confidence in the use of those skills; motivating students, so as to bring out the best in them, usually stretching them beyond what they thought they were capable of; observing the mentorees in action, evaluating their experience, and giving feedback to enhance self-learning and development. ${ }^{5}$

\footnotetext{
${ }^{1}$ General Conference of Seventh-day Adventists, Minutes of Meetings of the General Conference Committee, April 26-May 13, 1929.

${ }^{2}$ White, Gospel Workers, 101, 102.

${ }^{3}$ International Board of Ministerial and Theological Education, Handbook of Seventhday Adventist Ministerial and Theological Education (Silver Spring, MD: General Conference of SDA, 2001), 41, 42.

${ }^{4}$ Stanley and Clinton, 79.

${ }^{5}$ Ibid., 82.
} 
Readiness to learn is crucial to effective coaching. To arouse interest in learning, the great challenge in this process would be to apply Knowles's adult conditions of learning: to experience a need to learn; to perceive the goals of a learning to be their goals; and to accept a share of the responsibility for planning and operating a learning experience. ${ }^{1}$ They should also participate actively in the learning process, and have a sense of progress toward their goals. ${ }^{2}$

\section{Development of the Model}

This sub-section describes the personal discipleship methodology I developed in my coaching process with the students of NBC.

There are two major periods during a seminarian's formal theological training when the field dimension of that educational experience is incorporated into the student's total curriculum. One period is the academic year itself, while the student is in residence at the school from February to May. This is normally referred to as a concurrent field education. ${ }^{3}$ The other period occurs from September to November, when the student is away from the normal routines of school life, and coached by the supervising teacher in some church planting project. This has been called block placement. ${ }^{4}$

${ }^{1}$ Malcolm Knowles, The Modern Practice of Adult Education: Andragogy versus Pedagogy (Chicago, IL: Follett Publishing Co., 1998), 52, 53.

${ }^{2}$ Ibid.

${ }^{3}$ Ronald Hornecker, "Choosing a Ministry Placement and Field Supervisor," Experiencing Ministry Supervision: A Field-Based Approach, ed. William T. Pyle and Mary Alice Seals (Nashville, TN: Broadman and Holman Publishers, 1995), 24, 25.

${ }^{4}$ Ibid. 
Concurrent Field Education Placement is usually made in a large variety of field sites around the campus: churches, schools, and community areas which provide opportunities for evangelism and church planting. The normal time commitment for seminarians engaged in concurrent field education is twelve to fifteen hours each week or, in some special cases, eighteen to twenty-five hours each week.

Block Placement engages seminarians in an intensive full-time ministry within a specific block of time, apart from the normal routine of the school year. This occurs in large cities where students are divided into districts and assigned as evangelists or church planters, coached by the supervisor.

\section{Trainee Selection}

Some sort of selection is necessary in the context of theological education. Bill Hull defines selectivity as "the process of applying scriptural qualifications to the selection of leaders." If a seminary is simply interested in enrolling as many student as possible, with the minimum amount of screening and without local church endorsement, standards will inevitably decline. Local churches should play a far more active part in recruiting and mentoring individuals they deem suitable to receive further training.

Once students are accepted in the seminary program, they are automatically enrolled in the supervisory training. In my first experience with a group of fifty seminarians, I selected twelve among the group to be placed in an intensive full- time ministry for two months. At the time, selectivity created some consternation. It appeared

'Hull, 147. 
to be discriminating for some, unfair and incomplete for others. Some argued that the selection was based upon performance during the concurrent placement, when students had time limitations to balance work for tuition and family expenses, with academic pursuits and field activities.

It was observed that in this block placement, where ministry is highly focused and demanding, students were lifted out of their personal and ministry identity. In other words, only when they relied upon the resources of their inner person, under the pressures of the circumstances, did they gain understanding of themselves and their adequacy for ministry.

Considering that ample information to make a wise selection was only complete at the end of the block placements, I decided to take all the class under my personal coaching. Further considerations about the application of the principle of selectivity in my personal disciple-making are developed in the results/evaluation section.

\section{Field Site Selection}

Communication and cooperation with any Adventist organization operating in the selected area are indispensable. Sometimes the coordinator of the theological field education of $\mathrm{NBC}$ or the teacher-mentor has a preference for working in a certain area or for a certain conference/mission. This is understandable and ensures that he or she will take up the task with interest, courage, and enthusiasm. However, NBC does not enter any field without the approval of local church administration, because the conference provides financial resources and support for follow-up work. The criteria used to select the site takes into account the following characteristics. 
1. A setting where people are in crisis and/or experience change, with priority given to unreached areas, urban areas, and receptive areas ${ }^{1}$

2. A setting where appropriate resources are available in terms of finances from local administration and people who value and are open to working with ministerial candidates. It is also important for students to feel the dignity, pressure, and expectations which come with remuneration. Financial reward is a concrete way to signal to students the significance of the task they are doing. ${ }^{2}$

3. A setting where the supervisor's work is fully integrated with the structure of the local field. ${ }^{3}$ Only a supervisor with internal administrative authority, who works with local leaders, who already bear heavy burdens within the framework of the local field, can facilitate meaningful supervision. ${ }^{4}$

4. A setting where significant tasks for seminarians are provided. ${ }^{5}$ The students must perceive the task assignment as vital to the work of the local field through which services are being provided. The setting should provide students with decision-making 1977), 8.

${ }^{1}$ George I. Hunter, Theological Field Education (Boston: Boston Theological Institute, ${ }^{2}$ Ibid.

${ }^{3}$ This item is applicable to fields that request students to develop their evangelistic activities in their territory.

${ }^{4}$ Charles R. Fielding, "Education for Ministry," Theological Education, 3 (1966): 211.

${ }^{5}$ Hunter, 10. 
roles rather than making them errand runners. ${ }^{1}$ Unless students have significant roles, supervisors will not be able to see the students under the pressures of decision making.

5. A setting where in-depth experiences with people facilitate the transfer of learning. ${ }^{2}$ The program should be designed in such a way that seminarians are immersed in ministry with particular people in a specific place. Students need to be able to see their own impact upon people. They also need to see how they relate to individuals and groups at various levels and how they respond to them.

\section{The NBC Seminarians Model}

The model chosen to accomplish the coaching process among the seminarians of NB College followed the four training phases and six teaching steps of Christ, as presented by Bill Hull:

1. "Come and see"; Tell them what; Tell them why

2. "Come and follow Me"; Show them how; Do it with them

3. "Come and be with Me"; Let them do it

4. "Remain in Me"; Deploy them ${ }^{3}$

The four training phases focus on two essentials-time and level of commitment, while the six-step teaching method focuses on training and level of responsibility. ${ }^{4}$ This

'Doran McCarty, The Supervision of Ministry Students (Atlanta, GA: Home Mission Board, 1979), 62.

${ }^{2}$ Hunter, 11.

${ }^{3}$ Hull, 214.

${ }^{4}$ Ibid. 
approach means that all four phases fall into two major periods during formal training-the concurrent and the block placement. These four stages of training take one year to be accomplished; the process of action and reflection takes place in the context of the classroom and in a field setting.

\section{Phase 1: "Come and see"-Tell them what and tell them why}

According to Hull, Jesus built the disciples' conviction by delivering the Great Commission five times (the "what"), by providing a specific method for taking the good news to the ends of the earth (Matt 28:19, 20), and by explaining the reason (the "why") for this commission-the salvation of mankind. In the same way, it was necessary to train NBC students by emphasizing what must be done and why. ${ }^{1}$

The objective of this first phase was to provide a model of Christian education for mission and evangelism to be reproduced in the local church by future pastors. To initiate this phase I gave a series of four lectures (45 minutes for each class) to a group of fifty dedicated students in their third year of college.

During the first five months of each year, my task is to build conviction concerning the right process and the right philosophy to fulfill mission. In order to create a winning environment, I fostered spiritual preparation by maximizing the central place of the Holy Spirit in the mission of the church and by emphasizing the necessity for every student to be filled and led by the Spirit. Opportunities were provided for periodic renewal through

\footnotetext{
I'Ibid., 191-196.
} 
retreats and scheduled meetings for Bible study and prayer. The need for all students to surrender themselves to God as instruments of righteousness was also stressed.

To help individuals fit into the larger group and build group cohesiveness, a schedule for fun and relaxing activities, such as community meals and sports, was planned. It was also important to cultivate a spirit of winning by pointing out progress, even in moments of defeat. Most of the students had limitations of maturity, experience, and training; therefore they were insecure and afraid of failure. If they are to make progress, students must understand that it is acceptable to make mistakes. A growing atmosphere is an accepting atmosphere.

The normal curriculum for the third year of the NBC program contains a course in Personal Evangelism, Methods of Evangelism and Church Growth, and Public Evangelism, including general concepts in mission. The Public Evangelism course concentrates on devising strategies for church-extension evangelism in designated areas.

Although the need to develop spiritually by having regular times of personal devotions was stressed, a specific course in spiritual formation was not part of this phase because a balanced, structured program of spiritual formation is scheduled for the first year of the four-year program. Special emphasis was placed on understanding the Great Commission by balancing the disciple-making process with effective methods of evangelism, as well as emphasizing discipleship as the end-product of evangelism and the importance of the multiplication of disciples for world evangelization. 
Most of the time the classes were presented in the form of lectures with videos, Power Point presentations, and interaction between professor and students. Because students were older, they brought into the classroom not only questions, but experience and insight, often beyond that of the professor. Thus, the classroom became a conference room in which we could exchange, with contributions coming from different contexts.

At appropriate points the class was divided into small groups of four to six members each. In order to prepare for the concurrent phase, each unit not only did the class exercises, shared problems and ideas related to their individual and collective concerns, practiced and encouraged mutual spiritual disciplines, but also decided on a specific target area and people within a larger geographical area around the campus.

At the introductory stage, students talked about planning procedures and were introduced to the evangelistic strategy. They also coordinated demographic surveys of their target areas done by the students of the first year in the small cities around NBC. Then the members of each unit collaborated in the development of a master plan for their target area. Each member of a unit concentrated on two or three important aspects of each phase, and the teacher circulated among the groups to answer pertinent questions and to keep the discussion moving along desired lines.

In the last session each unit circulated rough drafts and reported the main outlines of its strategy for that phase of the strategy. Class members offered critiques and suggestions to be considered in the finalization of the various master plans. At the close of the classes, the units circulated completed master plans and were ready for the most important part to take place in the surrounding areas. 


\section{Phase 2: "Come and follow Me"-Show them how and do it with them}

According to Hull, this teaching step parallels Jesus' training phase when He separated out the Twelve and gave them special responsibility and authority. ${ }^{1}$ Jesus showed the disciples how to work and did the work with them in a controlled environment where disciple-making was provided in the setting of small groups. ${ }^{2}$ Hull also points out that "Jesus established that four essentials were needed to sustain a lifetime of commitment to Himself and the mission: a right relation to the word of God, prayer, relationships or shared life, and witness or mission. ${ }^{3}$

The small units that developed a master plan for their target area were now immersed in a ministry with a particular people in a specific place near the campus. During this concurrent field phase the students were encouraged by the pressures of time, circumstances, and supervision to integrate simultaneous experiences from the classroom and the field, to pay serious attention to spiritual formation, and to be engaged in the excitement, demands, and opportunities which ministry affords.

The plan of this on-the-job training provided one special week for the teacher/coach to conduct an evangelistic meeting where all students could watch and have the opportunity to clarify instructions. This week was followed by an intensive series of fourteen meetings directed by the small units of six students (ministry teams), thus

\footnotetext{
'Ibid., 197.

${ }^{2}$ Ibid., 225.

${ }^{3}$ Ibid., 221.
} 
providing a balance between doing ministry and reflecting upon that experience in the class.

For that reason, supervisory time was scheduled for the students and the teacher/coach to engage in systematic, disciplined reflection upon the ministry in which they were involved. This on-the-job training was added to the classroom training. In this process students took theological ideas out to their supervised ministry settings and brought back to the classroom their ministry experiences to examine for theological content.

These ministry teams had a clear mission, to which all contributed by combining their skills, gifts, and resources to move toward a meaningful goal. At this stage they had a controlled environment where they might experience and practice with the teacher, in order to fully understand the interlaced parts of the overall strategy and to master the dynamics of persuasion evangelism. They needed time to have all the instructions firmly established on a solid foundation and some assimilation time for review and rehearsal (intensive in August) before they were sent to phase 3.

\section{Phase 3: "Come and be with Me"-Let them do it}

This phase went from the time Jesus appointed the Twelve in Mark 3:13,14, until He commissioned them to go out two by two in Matt 10:1-42. ${ }^{1}$ The disciples went out to work under specific instructions that detailed everything from the message preached to the

'Ibid., 237. 
amount of luggage. Then, the process of practicing ministry was followed by an evaluation (Mark 6:30).

A brief examination of the methodology used by Jesus in the "come-and-see" phase suggests a large-group approach. He taught the Word to a multitude and then called some men to "come and follow Me." In the second phase, He trained them through small groups ${ }^{1}$ and in this third phase, He sent them out two by two.

As mentioned earlier, the block placements model engages students in an intensive, full-time ministry apart from the routine of the school year. From September to November, I took all fifty students to Teresina, State of Piaui, Brazil, where they had a supervised field experience in evangelism and church growth. This stage modeled decentralization of ministry, which gives fulfillment and a life of purpose. It also gave the trainee a strong sense of accomplishment. They were provided with the opportunity to prove themselves, to be productive, and to demonstrate disciple making and leadership techniques.

It was crucial in this mentor-student relationship to be as clear as possible about goals and expectations at the very beginning and throughout the mission. The criteria of evaluation were the student's skills, personhood, and performance, especially performing in ministry. Students were expected to plant a new church and start a disciple-making process with new members.

'Larry Osborne, "Equipping the Saints to Lead," in Growing Your Church through Training and Motivation, ed. Marshall Shelley (Minneapolis, MN: Bethany House Publishers, 1997), 97. 
The method of reporting used was based on informal discussions between students and coach-teacher during daily visits, on group reports during a weekly meeting of people engaged in a multiple-staff setting, and most frequently in counseling calls via cell phone used by the student/coach in the midst of a crisis. After evaluation, changes were made, correcting the direction of programs, adding or subtracting modules of programs, and sometimes transferring students from one place to another.

The logistics of starting programs was not left to chance, but there was a matching of students and placements along with previous planning. The field site was selected according to criteria previously explained. Months before the beginning of the evangelistic meetings, a survey was conducted in order to discover the average income, the employment rates, the great needs of the city, and places where people were in transition. Such visits and surveys aimed at helping the teams to gather information about important services or ministries that needed to be performed in the community. The coach-teacher also met local lay leaders, found the meeting places, located proper accommodations for students, and elaborated-with the help of local leadership-a preliminary plan.

Finally, when the strategy to be followed was defined, ${ }^{1}$ the plan was divided into four phases. First came the preparation of the local churches, to strengthen their spiritual motivation and sense of mission. This phase also included member enrichment, by discovering and utilizing the spiritual gifts of all the members in the setting of small groups. Second was the preparation of the territory by involving the majority of church

\footnotetext{
'A detailed description of this strategy is presented in the chapter 6 of this dissertation.
} 
members in providing felt-need seminars in the community and enrolling as many as possible in Bible courses.

Third, reaping crusades with a family and health approach were conducted to move people from secular to religious concerns. A pre-baptismal class in this discipling phase emphasized the basics of salvation and the essential doctrines of Christianity. Finally, the follow-up phase, through small groups, one-on-one mentoring, training seminars, involvement in tasks and roles, and also monitoring the assimilation, took place for at least six months after the students' departure.

\author{
Phase 4: "Remain in Me"-Reproduction phase \\ In the following year, graduation was a time of celebration when a well-trained \\ group of ministerial students was deployed to begin their ministry as disciple-making \\ pastors in new places. They left physically but continued to keep contact as occasional \\ mentorees with their teacher.
}

The Coach-Teacher Role

The experience of a teacher/coach mentor is a two-way learning event, where the student`s experience counts for as much as the teacher's knowledge. It is sometimes difficult to discover who is learning more, the teacher or the student, because it is the evaluation of their mission project that reveals the insights which help elaborate new approaches and methodologies.

McCarty affirms that coaching seminarians requires an endless number of skills. The coach needs all the skills of an evangelist, a congregational minister, a theology 
professor, and a counselor, as well as specific skills in supervision methodology. ${ }^{1}$ Besides those ministry skills, the teacher also needs to have a good academic training in order to help students get in touch with the theoretical base from which they are operating and the theological/missiological implications of what they are doing. ${ }^{2}$

Coaches need to have relational skills which will enable them to relate appropriately to students, pastors, and local church administrators, because they have to create an atmosphere of trust, which is an indispensable environment for learning. ${ }^{3}$ They must have skills in organizational development to create strategic planning and the capacity to carry it out fully. At the same time, they need some experience in leading a high-risk enterprise, which requires attracting talented and committed people and raising the necessary money for the enterprise to function.

Coaches must also have authority to make decisions about assignments and finances in the management of the students mission project. The coach needs to be able to operate with a legitimate degree of authority from within the system. There can be no "absentee supervisor," for the coach represents the college, the church organization, and also the students. ${ }^{4}$

The most important role of a coach/teacher is to help students achieve personal and professional identity, to develop the disciplines of scheduling, planning, finances, and

\footnotetext{
${ }^{1}$ McCarty, 29.

${ }^{2}$ Ibid.

${ }^{3}$ Hunter, 23-29.

${ }^{4}$ Ibid.
} 
devotional experiences, and to examine their ministry to see how they are doing, and whether they are meeting expectations. A coach is not a passive individual who stands by and watches students do as they please. Nor should coaches be so inflexible that they demand that students always do whatever they say.

\section{Results / Obstacles / Evaluation}

As a result of this model of disciple-making among ministerial students at NBC in 2001, 2,200 new members were brought to repentance and faith in Christ and joined a local church as responsible members during the first year of evaluation. Seven new churches were planted in the target area chosen for the block placement, from September to November. A follow-up program for the retention, maturation, and multiplication of the fruit of evangelism was developed for six months.

Although 19 percent apostasy rate (per year) should be celebrated when compared to former years ( 40 percent), an evaluation reveals that there is still much work to be done in order to correct the discipleship deficit.

Some obstacles faced in the concurrent field work were related primarily to time limitations. Sometimes, due to the part-time nature of the commitment, the students were inclined to feel that the expectations of the field program intruded upon valuable time which should be spent on academic pursuits. This feeling occurred most often when term papers were due or examinations were imminent.

Considering important aspects of disciple-making discussed and experienced in this dissertation, the following issues need to be added to the stages of training: 


\section{Phase 1: "Come and see"}

1. Read syllabus and assigned reading before coming to class. Then the classroom experience can be used to process what students have learned and to stimulate discussion. Another innovation would be students participation in formulating the curriculum for the class taught in the equipping phase.

2. The small units of six students designed to do class assignments, planning, and act as ministry teams to a specific area should be broken up into triads at appropriate times, with the purpose of helping students examine where their spiritual state. This nonhierarchical structure creates a more simple and natural environment for a dynamic interchange, which facilitates equipping, accountability, and encouragement in their spiritual journey.

3. The plan elaborated by the students in this phase will feature reproducing disciples as the central goal of their church-planting mission.

\section{Phase 2: "Come and follow Me"}

It is important that the ministry teams have a clear mission during the concurrent placement, where techniques and methodologies are reviewed. This is not to overestimate the value of the continued relationship in the triad structure, where students hold one another accountable for the team's progress, mutual encouragement, and mutual equipping in skills, disciplines, and behaviors. This makes it important for students to learn

'This approach was inspired by Dr. Ricardo Norton's course, "Strategies for Church Growth," Andrews University, September 2002. 
that their own spirituality is a distinctive facet of their personal and professional identity, so that they are not tempted to rely only on techniques and methodologies.

\section{Phase 3: "Come and be with Me"}

1. It is obvious that the students' new disciples had much more to learn than the basics of salvation and the essential doctrines of Christianity. They also needed to learn essentials of discipleship, personal ministry, and spiritual formation. Although the postbaptismal class was supposed to work in the sequence of the strategy, it lacked a planned curriculum. This curriculum will be considered in the chapter 6 .

2. There is a need to have an instructional group for a special purpose. Similar to the "Select Society" developed by John Wesley,' the purpose in creating such a group is to improve students leadership skills in church growth, to have a select company for accountability, and to provide a pool of available and ready leaders to multiply the disciples. The criteria for the selection of these leaders should be based on character, faithfulness, and gifts. The idea is to interact with twelve students who could effectively articulate the philosophy of disciple-making, manage or coach others, and equip and motivate others in discipleship through evangelism and church planting. In other words, they will pass the baton ( $2 \operatorname{Tim} 2: 2)$. During a six month period they would be equipped with an advanced curriculum and deployed on short-term missions of training and coaching others.

'Henderson, 121-126. 
While the flow of the process has been described in this chapter, evaluation is the focus of chapter5. The information obtained from surveys and interviews help and can provide the basis for creating a discipleship model. 


\section{CHAPTER V}

\section{THE DISCIPLESHIP OF NORTHEAST BRAZIL}

This chapter describes a study of recently baptized members in churches in Teresina. From the information gathered in this survey, important elements of a discipleship plan are analyzed.130

\section{Profile of NB}

This first section seeks to examine NB environment by considering its brief history, some demographic elements, and the development of the SDA church in this area.

\section{Brief History}

On April 22, 1500, the thirteen-ship fleet under Pedro Alvares Cabral anchored off the mouth of the River Buranhem on the Bahian coast, in northeast Brazil.' The Portuguese initially made little of their new Western hemisphere territory; their colonizing efforts were directed at India. Nevertheless, after various exploratory expeditions sent to Brazil, the main product of interest to the Europeans was brazilianwood, which gave its name to the territory.

'Federal Research Division Library of Congress, Brazil: A Country Study, ed. by Rex A. Hudson (Washington, DC: US Government Printing Office, 1998), 14. 
Because of the constant French incursions in this new land and their exploration of brazilianwood for the production of dyes for textiles, the Portuguese finally decided to occupy the land. ${ }^{1}$ The king of Portugal divided it into fifteen huge captaincies which were granted to nobles and other servants of the crown. They in turn gave large estates to their family and friends, who began to raise sugarcane, tobacco, and cotton along the northeast coast and cattle in the northeast backlands. ${ }^{2}$

The Brazilian society was composed of a miscegenation of native American people, African, and Europeans. The Portuguese, who were already using African slaves in Portugal, began to import them to Brazil in $1538^{3}$ to work in the economy of the new colony. Another slice of Brazilian society was constituted by exiles banished from their homeland because they had violated the strict laws of Portugal. The historian Joseph Pale describes them as "nonconformists, often from influential families, some found success in their new lives; others became the dregs of their communities." But the European portion of Brazilian society also had its noble representatives. The pressures on Jews and nonCatholic Christians in Portugal forced hundreds to emigrate to Brazil. ${ }^{5}$ The majority of the pioneers who made Bahia and Pernambuco the most successful of the early settlements

'Zwinglio M. Dias and Joyce Hill, Brazil: A Gracious People in a Heartless System (New York: Friendship Press, 1997), 5.

${ }^{2}$ Ibid.

${ }^{3}$ Ibid., 5. 1995), 41.

${ }^{4}$ Joseph A. Page, The Brazilians (Menlo Park, CA: Addison-Wesley Publishing Company,

${ }^{5}$ Donald E.Worcester, Brazil: From Colony to World Power (New York: Charles Scribner's Sons, 1973), 19. 
were Christians. ${ }^{1}$

Inspired by the American Revolution, which represented Americans' similar dissatisfactions with Britain, and the French Revolution, Brazilians started several small, secret independence movements. The most important was the rebellion of idealistic students and poets in 1789 , known as Inconfidencia Mineira. ${ }^{2}$ Other insurrection movements occurred in Bahia in 1798 called "conspiracy of the tailors"3 and again in Pernambuco in 1817. In an age of change, these revolts illustrate the surprising degree to which European revolutionary ideas had spread among the ordinary people of northeast Brazil.

In 1808, fleeing from the Napoleonic wars, the Portuguese regent, Dom Joao, took his entire court into exile in Brazil. ${ }^{4}$ When he was recalled to Portugal in 1821 , he left his son, Dom Pedro, as a regent. ${ }^{5}$ In mid-February 1822 , Bahians revolted against the Portuguese forces, and in September 7, in a famous scene at Ipiranga, Dom Pedro declared Brazil's independence from Portugal. ${ }^{6}$

\section{Demographics}

The nine states that make up the Northeast are Alagoas, Piaui, Sergipe, Bahia,

'Ibid.

${ }^{2}$ Worcester, 50 .

${ }^{3}$ Ibid., 53.

${ }^{4}$ Federal Research Division, 37.

${ }^{5}$ Ibid., 38.

${ }^{6}$ Ibid. 
Pernambuco, Rio Grande do Norte, Paraiba, Ceara, and Maranhao. With 1,561,178 square kilometers, the Northeast covers 18.3 percent of the national territory. ${ }^{1}$ Its principal biome is the semiarid caatinga region, which is subject to prolonged periodic droughts. In an area known as the forest zone (zona da mata), the Atlantic Forest, now almost entirely gone, once stretched along the coastline as far north as Rio Grande do Norte. According to a Brazilian researcher, drought has been a persistent hazard to NB throughout its history. ${ }^{2}$ This drought hazard has been one of the fundamental push-factors of the migratory phenomenon from NB to other regions.

In 2001 the region had 47,782,488 million inhabitants, 27.9 percent of Brazil's total population. The population is densest along the coast, where eight of the nine state capitals are located, but is also spread throughout the interior. The major cities are Salvador, in Bahia; Recife, in Pernambuco; Fortaleza, in Ceara; and Teresina, in Piaui with 715,360 inhabitants.

Distribution of wealth in Brazil is extremely unequal and NB's living standards are the lowest in Brazil. Income distribution is couched in terms of proportions of population earning below, at, or above the minimum salary (expressed in monthly terms and equivalent to less than US $\$ 100$ ). NB has the largest rate of people who live with just one minimum salary (41 percent) and the lowest group to live with above four minimum salary

I'Ibid., 101.

${ }^{2}$ Manoel Correa de Andrade, Paisagens e Problemas do Brasil (Sao Paulo: Editora Brasilense, 1968), 112-119.

${ }^{3}$ Ronald M. Schneider, Brazil: Culture and Politics in a New Industrial Powerhouse (Boulder, CO: Westview Press, 1996), 172. 
(6.6 percent). ${ }^{1}$

The Brazilian anthropologist Gilberto Freire emphasizes the flexibility of the Portuguese, as well as the African roots of the Northeasters. ${ }^{2}$ They are known for their informality, good nature, and charm (simpatia), as well as their desire not to appear unpleasant or boorish. ${ }^{3}$ They place high value on warmth, spontaneity, and lack of pomp and ceremony.

Brazil is considered the largest Roman Catholic country in the world. ${ }^{4}$ In 2001 about 73 percent of the population, or about 124,980,132 million people, declared Roman Catholicism as their religion. ${ }^{5}$ Syncretism, the combination of different forms of belief or practice, has been widespread in the Northeast, where Roman Catholicism has blended with numerous Afro-Brazilian cults. These combinations are called Umbanda or

\section{Candomble. ${ }^{6}$}

In recent decades, Protestantism has grown rapidly. The proportion of the population considered evangelical grew from 6.6 percent in 1980 to 15 percent in 2001 .

\footnotetext{
1"Rendimento Mensal," Government of Brazil, 2000

http://www.ibge.gov.br/home/estatistica/populacao/censo

2000/primeiros_resultados_amostra/grandes_regioes/pdf/tabela (3/12/2005).

${ }^{2}$ Gilberto Freire, The Masters and the Slaves: A Study in the Development of Brazilian Civilization (New York: Alfred A. Knopf, 1946), 185.

${ }^{3}$ Ibid., 284.

${ }^{4}$ Federal Research Division, 133.

5“Populacao segundo a religiao," Government of Brazil, 2000, http://www.ibge.gov.br/home/estatistica/populacao/censo 2000/primeiros_resultados_amostra/brasil/pdf/tabela_1_1_2.pdf (3/11/2005).

${ }^{6}$ Dias and Hill, 53.
} 
Nearly half of Brazil's evangelicals, or $8,418,140$ million, belong to the Assembly of God. The Universal Church of the Kingdom of God is but one of a number of Pentecostal sects that are in the forefront in the vertiginous growth of evangelical Protestantism in Brazil.

The SDA Church

In his book Pioneering the Neglected Continent, pastor Frank Westphal reports how the first Brazilians accepted the message and he organized the first Brazilian church of only 23 members in Brusque, Santa Catarina state, in 1902. ${ }^{1}$ The first attempt to sow the Adventist message in South America was done through a literature distribution program by a team of colporteurs landed in Montevideo, Uruguay, on December 10, $1891 .^{2}$ Then, the General Conference sent the first missionary team in order to establish the SDA church in South America-the Westphal's family and the colporteur W. H. Thurstons. $^{3}$

When the South American Union was created in 1906, Brazilian territory was rearranged to form two conferences, the Rio Grande do Sul, and the second, the Santa Catarina and Parana Conference. The rest of the continent was split into six missions: Ecuador, Peru, Chile-Bolivia, Uruguay, Upper Parana (Argentina and Paraguay), and

'Frank Westphal, Pioneering the Neglected Continent (Nashville, TN: Southern Publishing Association, 1927), 30-43.

${ }^{2}$ Milchelson Borges, A Chegada do Adventismo ao Brasil (Tatui, SP: Casa Publicadora Brasileira, 2001), 10.

${ }^{3}$ Floyd Greenleaf, The Seventh-day Adventist Church in Latin America and the Caribbean (Berrien Springs, MI: Andrews University Press, 1992), 1:17. 
North Brazil (all of Brazil north of Sao Paulo). ${ }^{1}$ After a time of consolidation and expansion due to progress in literature distribution and a large-scale urban evangelism, the formation of the South American Division was necessary in $1915 .{ }^{2}$ Within months the original Brazil Union changed its title to the South Brazil Union, and was later renamed East Brazil Union.

The formation of a second union in Brazil was a major organizational shift, when portions of the EBU separated into the North Brazil Union (Pernambuco and Minas Gerais). But in 1919, EBU was reconstituted again with five missions: Rio de Janeiro, East Minas, Espirito Santo, Bahia, and Pernambuco. ${ }^{3}$ Ceara, Piaui, and all NB remained unentered areas.

From its origins in the southern corner of the country, the geographical advancement of the SDA church in Brazil was northward. Growth in the Bahia and Pernambuco Mission represented this trend. Leo Halliwell, who was to become a legend along the Amazon during a missionary career spanning four decades, began his service in Bahia in 1921, immediately after his arrival in Brazil. ${ }^{4}$ By the end of 1930 the mission, consisting of states of Bahia and Sergipe, claimed 258 members. ${ }^{5}$ Farther to the north, the states of Pernambuco, Alagoas, Paraiba, and Rio Grande do Norte comprised the much

${ }^{1}$ lbid., 90.

${ }^{2}$ Ibid., 122.

${ }^{3}$ Ibid., 243.

${ }^{4}$ Leo Halliwell, Light in the Jungle (Mountain View, CA: Pacific Publishing Association, 1972), 26-31.

${ }^{5}$ Greenleaf, 276. 
larger Pernambuco Mission.

After phenomenal growth, in late 1996 portions of the EBU separated into the NB Union Mission. This new organization comprises the Bahia, Pernambuco, and South Bahia Conferences and the North Coast (Ceara and Piaui), Northeast Brazil (Rio Grande do Norte and Paraiba), Sergipe-Alagoas, and Central Bahia Missions. There are 267 ordained and licensed ministers, and 905 churches with about 212,208 members in a total population of $40,586,720$ inhabitants (pop./member $1: 191$ ). ${ }^{1}$

An important element in NB growth has been lay evangelism. Scarcity of ministers to cover its huge territory has given laymen's activities a special importance. Public evangelism, small group activities, and youth and educational programs also formed an increasing significant aspect of NB Union Mission's plans to reach a rapidly growing population.

\section{The Field Study}

This section presents the basic findings of a survey of new disciples and of a interview with former disciples in Teresina, to discover the effectivity of making disciples through public evangelism and church planting by seminarians. A rationale for conducting the survey and the interviews, the methodology, and an analysis of the data collected by seminarians are presented in this study.

${ }^{1}$ Seventh-day Adventist Yearbook 2001, 269. 


\section{Rationale for the Field Surveys and Interviews}

Having worked in Northeast Brazil as a seminary professor and evangelist for six years, and recognizing the tremendous challenge that pastors face in using public evangelism as the first link in the chain of spiritual multiplication, it became increasingly urgent to conduct a study that would secure information from newly baptized people and those who had abandoned the faith. Furthermore, an analysis of the survey was critical to ascertain the current discipleship gap and the factors which have contributed to this condition.

Success among SDAs is often thought to be in proportion to the number of new members. For this reason the pastor or the evangelist may be tempted to make short-range plans aimed at a large baptismal target, but with little thought beyond that ceremony. Yet a few years later, the same statistical success is not always reflected, either in church membership or in the number of new congregations. For this reason, the purpose for doing these surveys and interviews was twofold:

1. To evaluate the effectiveness of the evangelistic efforts carried out by seminarians by examining the characteristics of the new disciples and identifying the type of people they have been reaching.

2. To chart the progress of maturation of new members and of their integration into the life and service of the congregation through the discipleship process.

Only with careful research it is possible to determine just how deep is the discipleship deficit and what are the symptoms of superficiality the church. Only when the causes of the low level of discipleship are known is it possible to address them. 


\section{Methodology}

In her book, Projects That Matter, Kathleen A. Cahalan declares that surveys are "the most efficient means for collecting information from a large group of people," for they help "to gather responses to sensitive questions that participants may not feel comfortable answering in an interview."2 While surveys are "helpful instruments to gather people's attitudes and impressions," interviews are a popular method in evaluation because they "allow evaluators to ask people to explain their attitudes, feelings, and aspects of their experience that are not always observable." ${ }^{״ 4}$

The New Disciple Survey and The Former-Adventist Interview material used in this research was obtained from Roger L. Dudley, from the Institute of Church Ministry (ICM) at Andrews University, and used with permission. ${ }^{5}$ The New Disciple Survey offers respondents a set of predetermined answers. The answers can be as simple as yes or no, or involve multiple choice, usually up to seven possible responses. There are a continuum questions which offer a range of responses between two end points, such as "strongly agree" and "strongly disagree." Some questions also allow respondents to create their own answers to a question.

${ }^{1}$ Kathleen A. Cahalan, Projects That Matter: Successful Planning and Evaluation for Religious Organizations (Bethesda, MD: Alban Institute, 2003), 63.

${ }^{2} \mathrm{Ibid}$.

${ }^{3}$ Ibid., 65.

${ }^{4}$ Ibid., 61

${ }^{5}$ Roger L. Dudley and Des Cummings, Jr, Adventures in Church Growth (Washington, DC: Review and Herald Publishing Association, 1983), 120-123, 138-141. 
The purpose of the survey is to identify the type of people NBC students have been reaching and the kinds of people in the community that present techniques of evangelism are not touching. This will allow evangelists to discover people's felt needs and experiment with new approaches to effective evangelism. Several questions explore the new member's road to discipleship within the church in areas such as spiritual formation, witnessing, fellowship, and perseverance.

The Former-Adventist Interview schedule involved asking questions determined in advance, and asks respondents to choose from a set of fixed responses. This type of interview is often used in opinion polls. ${ }^{1}$ The order of the questions followed a logical flow in discussing the experience of the former disciple. The interview began in a spiritual, yet nonthreatening way and moves into some of the deeper areas. The visitor did not give the schedule to the former-Adventist but asked the questions. When the person was still officially a member but not attending, the visitor was oriented to omit questions 16 and 18. ${ }^{2}$ The goal was to search for possible harmful elements that could be eliminated to avoid future mistakes, to assess whether ex-disciples' real reasons for dropping out resulted from doctrinal problems or interpersonal relationships, and to search for ways in which the discipleship process could be improved.

The 44 evaluators were ministerial students from NBC who conducted 44 small evangelistic campaigns resulting in ten new churches and the baptism of $1,900^{3}$ people in

${ }^{1}$ Cahalan, 61.

${ }^{2}$ Dudley and Cummings, 143.

${ }^{3}$ From the 50 evangelistic points which resulted in 2,200 new members, only 44 were in the 
Teresina, PI, from September to November 2001. Six months after the crusade the seminarians returned to their churches to check on the follow-up and post-baptismal activities. This follow-up visit lasted a little more than one week, during which the students conducted evening meetings with a revival theme. Nevertheless, the main purpose for this return was to conduct the research among new disciples as well as former disciples.

The students were highly motivated. They wanted to accurately analyze the results of their evangelism. They wanted to increase their fruitfulness as God's harvesters. They realized that the survey and interviews would give them something measurable by which continuing evaluation of their efforts might be possible.

The students collected 134 New Disciples surveys from 20 selected churches among the 44 where evangelism took place. As a pilot study, this the number of samples are designated to "obtain preliminary information on how new procedures and instruments work." Therefore, "pilot studies are usually conducted on small samples, such as 10 to 100 people."

Selection of churches to be surveyed was based on the location of the church and how well it represented different social groups. Participants were randomly chosen by

territory of NBUM $(1,900)$. Since a river split the city in two parts and six other evangelistic points belonged to the North Brazil Union, only the students who worked in NBUM area were considered for this survey.

${ }^{1}$ Mildred L. Patten, Understanding Research Methods: An Overview of the Essentials (Glendale, CA: Pyrczak Publishing, 2004), 55.

${ }^{2}$ Ibid. 
students at a given Sabbath service. In these churches they also gathered 56 interview schedules from former or inactive Adventists.

Another method used to gather information was through direct observation by 20 ministerial students. The advantage of inside observers is that they can often see and hear important nuances and meanings that outsiders may fail to understand. They were provided with a set of questions to guide their observations, and the data are also included in this section.

After collecting information from surveys and interviews, the Statistical Package of Social Science software was used to compare findings and to display the results in a manner that made them easily readable.

\section{Analysis of Data}

This section identifies the key findings of the surveys with new disciples and the interviews with former Adventists by calculating quantities, analyzing qualitative data, selecting important information, and comparing findings. It also seeks to interpret the meaning of the findings by offering possible explanations and examining contexts.

\section{The New Disciple Survey}

The demographic questions asked of converts brought into a particular church surveyed showed that 71.4 percent were between 11 and 30 years of age (see table 2). That is a good news when the importance of the youth to the strength, well-being, and survival of the church is considered. On the other hand, one notices an unusually high rate of female converts (64.9 percent) to male converts (35.1 percent). This compares to 
315,309 men and 361,389 women in Teresina census. ${ }^{1}$ No convincing explanations have emerged as to why most churches attract more women than men. ${ }^{2}$ It would appear that the dynamic of the meetings, with social themes appealing to young people, such as "The Secret of Happiness" and "Courtship" attracted them most. The witness of members' lives and the charisma of the evangelists (most of them youth and single males) also sparked interest in Adventism.

TABLE 2

AGE AND GENDER OF PEOPLE ATTENDING EVANGELISTIC MEETINGS

\begin{tabular}{lcccccc}
\hline & \multicolumn{2}{c}{ Male } & \multicolumn{2}{c}{ Female } & \multicolumn{3}{c}{ Total } \\
Age & $N$ & $\%$ & $N$ & $\%$ & $N$ & $\%$ \\
\hline $0-10$ & 3 & 100 & 0 & 0 & 3 & 100 \\
$11-20$ & 24 & 38.1 & 39 & 61.9 & 63 & 100 \\
$21-30$ & 10 & 33.3 & 20 & 66.7 & 30 & 100 \\
$31-40$ & 6 & 26.1 & 17 & 73.9 & 23 & 100 \\
$41-50$ & 1 & 16.7 & 5 & 83.3 & 6 & 100 \\
$51-60$ & 1 & 25 & 3 & 75 & 4 & 100 \\
$61-70$ & 1 & 25 & 3 & 75 & 4 & 100 \\
$71-80$ & 1 & 100 & 0 & 0 & 1 & 100 \\
\hline Total & 47 & 35.1 & 87 & 64.9 & 134 & 100 \\
\hline
\end{tabular}

1"Teresina," Government of Brazil, 2000, http://www.ibge.gov.br/home/estatistica/populacao/censo 2000/primeiros_resultados_amostra/brasil/pdf/tabela_1_1_2.pdf (2/1 1/2005).

${ }^{2}$ Monte Sahlin, Adventist Congregations Today: New Evidence for Equipping Healthy Churches (Lincoln, NE: Center for Creative Ministry, 2003), 37. 
In table 3, demographic information shows that some 62 percent were single and 31.3 percent were married. One would expect this ratio of marital status because of the younger age of the new members. Those surveyed were primarily students ( 55.2 percent) and domestic servants (23.9 percent). Concerning religious background, more than half of the converts came from the Catholic Church (52.2 percent). In addition, 10.4 percent came from Evangelical churches, and 29.1 percent were unchurched.

\section{TABLE 3}

MARITAL STATUS, OCCUPATION, AND RELIGIOUS BACKGROUND OF CONVERTS

\begin{tabular}{lrrlrrlrr}
\hline $\begin{array}{l}\text { Marital } \\
\text { Status }\end{array}$ & $N$ & $\%$ & Occupation & $N$ & $\%$ & Religious Background & $N$ & $\%$ \\
\hline Single & 83 & 62.0 & Students & 74 & 55.2 & Catholic church & 70 & 52.2 \\
Married & 42 & 31.3 & $\begin{array}{l}\text { Domestic } \\
\text { servants }\end{array}$ & 32 & 23.9 & Evangelical church & 14 & 10.4 \\
$\begin{array}{l}\text { Divorced/ } \\
\text { Separated }\end{array}$ & 5 & 3.7 & Others & 26 & 20.9 & Unchurched & 39 & 29.1 \\
Widowed & 4 & 3.0 & & & & Others & 11 & 8.3 \\
\hline Total & 134 & 100 & Total & 134 & 100 & Total & 134 & 100 \\
\hline
\end{tabular}

When asked which were the most persuasive factors in their decision to join the Adventist church, nearly half ( 49.3 percent ) said that the truth and the beauty of the church's teachings persuaded them to join the church. See table 4. Their spiritual experience can best be categorized as journey toward truth. The charisma of the evangelists (23.1 percent) and the warm fellowship among the members (23.1 percent ) also had a significant influence. 
According to the responses obtained, 27.8 percent of these new disciples experienced some personal or family emotional crisis before joining the church, while 17.7 percent had severe financial difficulties, and 19.0 percent had experienced death or illness of a close friend or relative. This confirms that times of change or transition in a person's life cause receptivity to a new lifestyle that includes Christ and the church. ${ }^{1}$ Such events prompted a reordering of priorities and values, and a reaching out for help to meet needs not experienced before. ${ }^{2}$ The factors influencing the decision to join the Adventist Church are presented in table 4 .

TABLE 4

FACTORS INFLUENCING THE DECISION TO JOIN THE SDA CHURCH

\begin{tabular}{lrrlrr}
\hline Persuasive factor & $N$ & $\%$ & Disruptive events & $N$ & $\%$ \\
\hline Church's teaching & 66 & 49.3 & Death or illness & 19 & 19.0 \\
Warmth of members & 31 & 23.1 & Personal crisis & 22 & 27.8 \\
Evangelist & 31 & 23.1 & Financial difficulties & 14 & 17.7 \\
Born Adventist & 4 & 3.0 & Marriage & 7 & 8.9 \\
No response & 2 & 1.5 & $\begin{array}{l}\text { Others (loss of job, birth of child, } \\
\text { moving, etc) }\end{array}$ & 17 & 26.6 \\
\hline Total & 134 & 100 & Total & $79 *$ & 100 \\
\hline
\end{tabular}

When asked how much influence the various evangelistic methods listed had on their decision, 84 percent said that evangelistic meetings were the most helpful (see fig. 1).

\footnotetext{
'Win Arn and Charles Arn, The Master's Plan for Making Disciples (Grand Rapids, MI: Baker Books, 1998), 87.

${ }^{2}$ Edward A. Rauff, Why People Join the Church (New York: Pilgrim Press, 1979), 96.
} 
This number was followed by Bible lessons with a church member in their home (74 percent), the instruction of a Bible worker (72 percent), pastor evangelist (56 percent), small groups ( 55 percent), influence of relatives ( 46 percent) and health program ( 34 percent).

The reason these first four figures are so high is that these were mostly converts from a series of meetings. They claimed to have been reached through the formal efforts of a congregation that initiated an evangelistic thrust within the community. Nevertheless, a city-wide crusade should not be thought of as a single method, but rather as a mission whose scope encompasses an entire city or metropolitan area, and which employs a variety of methods based on biblical principles. The experience in Teresina shows that a crusade is effective when it is looked upon, not as an isolated event or end in itself, but rather as part of a process of achieving long-term goals.

The methods used to view people do not seem to have made a great difference in their present relationship with the church, except for a slight increase of a "strong" and "very active" among those who were involved in small groups before their decision. Before formally uniting with a SDA congregation they became part of a group, and therefore were more easily assimilated. 


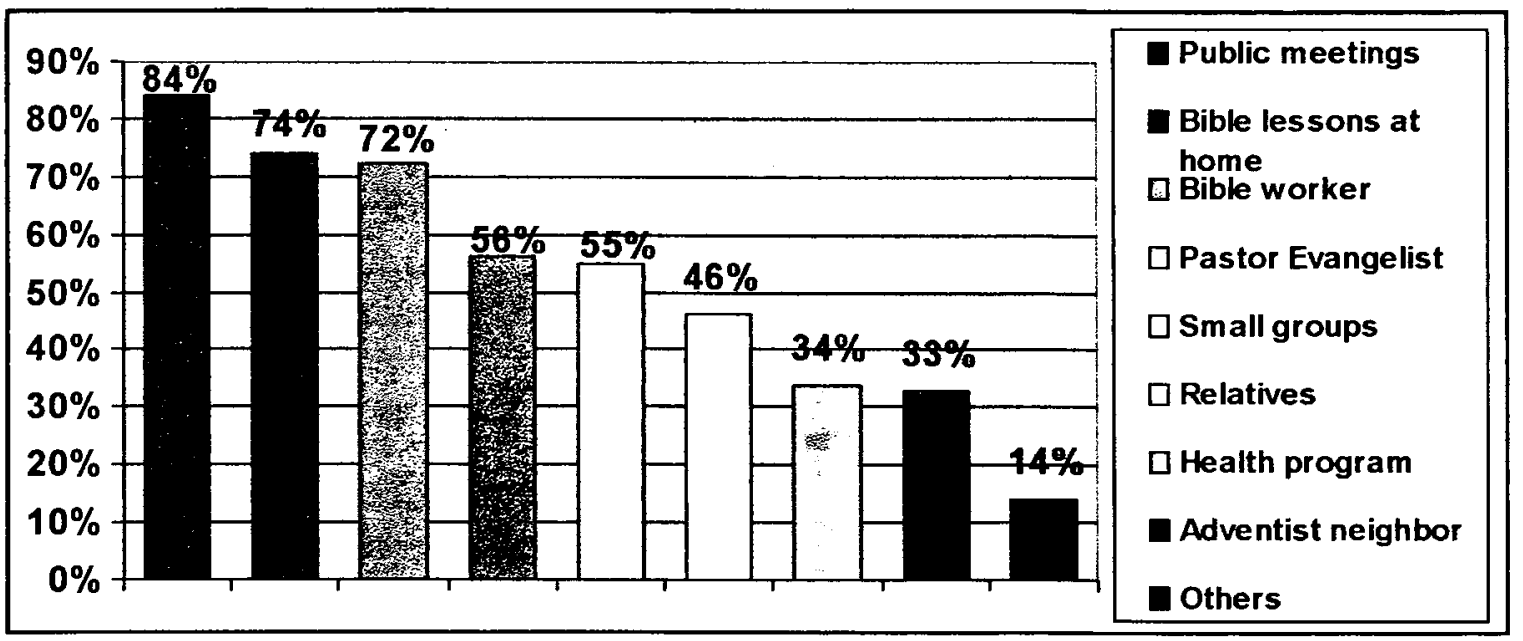

Figure 1. Activities influencing the decision to join the SDA Church.

Table 5 shows that the majority of the respondents who had attended the evangelistic campaign learned of the meetings through a friend (34.4 percent). Another 31.3 percent received an advertisement delivered at their door by a church member whom they did not know. Another 22.9 percent reported that they were invited by a church member whom they knew. The conclusion is clear: the majority of people can trace their "spiritual roots" directly to a friends or associates. Christians, intentionally or casually or even without realizing it, were a force drawing people to the church. Their witness was made by silent example or by verbal testimony.

However, the survey findings in Teresina also suggest that although every Christian can make a friend, many of them do not feel adequate to present the gospel to that friend. If we are encouraging our church people to be involved in building redemptive relationships, we need to assist the members in reaching their friends by providing opportunities to present the gospel. Evangelistic meetings were these harvest 
opportunities for members in Teresina.

TABLE 5

HOW DID PEOPLE LEARN ABOUT THE EVANGELISTIC MEETINGS ?

\begin{tabular}{lll}
\hline Invitation & $\mathrm{N}$ & $\%$ \\
\hline Friend & 45 & 34.4 \\
Unknown church member & 41 & 31.3 \\
Known church member & 30 & 22.9 \\
Others (radio, TV, car sound system) & 15 & 11.4 \\
\hline Total & 131 & 100 \\
\hline
\end{tabular}

As a part of the assimilation process in a local congregation (see fig. 2), most of the new disciples reported personal Bible study as the best resource in strengthening their spiritual life and Christian experience (51 percent). Another 38 percent mentioned church service, and 27 percent regarded small groups as an important factor.

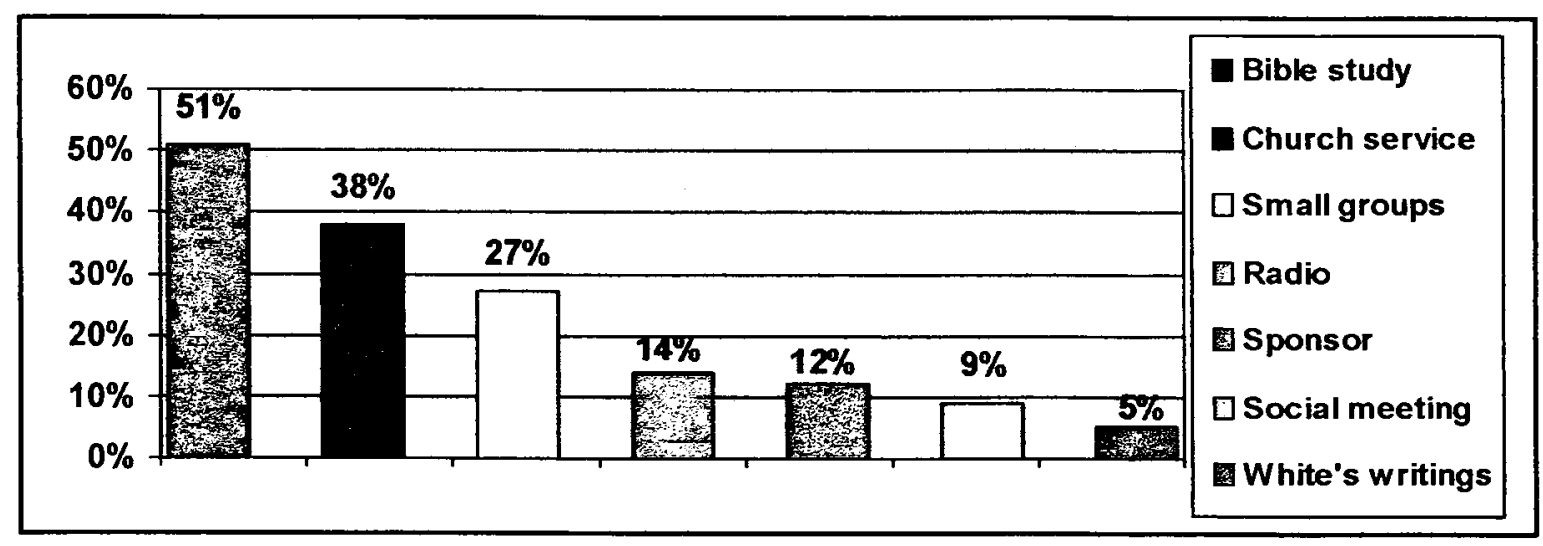

Figure 2. Resources strengthening the spiritual life of new converts. 
Comparing the resources reported for strengthening new members's spiritual life with information about their present relationship with the church shows a slight percentage of "strong" and "very active" in the profile of those who mentioned personal Bible study as a helpful resourceful to their spiritual life. There was also a decrease in the number of those who were "very weak" among those who participated in small groups.

Table 6 shows that when asked new members what method they used for witnessing for Christ, most of them shared their personal testimony of what God has done for them (36.4 percent). Twenty nine percent preferred to give out literature, and 20.9 percent gave Bible studies. They probably tended to imitate the methods used to evangelize them.

TABLE 6

METHODS USED BY NEW CONVERTS TO WITNESS FOR CHRIST

\begin{tabular}{lcc}
\hline Method & $N$ & $\%$ \\
\hline Personal testimony & 47 & 36.4 \\
Giving out literature & 38 & 29.5 \\
Giving Bible studies & 27 & 20.9 \\
Others & 17 & 13.2 \\
\hline Total & 129 & 100 \\
\hline
\end{tabular}

Regarding the type of fellowship they found in the Adventist church, nearly half of the new disciples who responded described it as very warm and loving (47.8 percent). A friendly atmosphere made some interviewees feel at home when they visited a church. Others reported finding their churches to be friendly and making some good friends ( 42.5 
percent). Two thirds of the converts rated their present relationship to the church as strong and very active, and one third describe it as lukewarm or very weak. This last group indicated the possible presence of harmful elements that are undermining the spiritual growth of the new disciples.

\section{Interviews of Former Adventists}

It is important to acknowledge that the data collected on former members is problematic in that it is always gathered after individuals leave the church. The data supplied by the dropouts reflect the way they feel when they are being interviewed. They may choose to be less than candid in their responses. They may answer the questions in ways that seek to justify their actions. The reader needs to keep this reality in mind when reading the materials that follow.

Table 7 reveals that the majority of the dropouts interviewed were female ( 63.8 percent), and young (52 percent). This makes sense because the number of female and young converts was high. Drop-out rates reflect that teenagers are more susceptible to social pressure from non-Christian friends and relatives, especially if they are the only Adventists in the family. It is also possible that they perceived the church as having little of worth to offer them as individuals.

The first thing that one notices in table 8 is that 55.4 percent of those interviewed had no previous experience with the Adventist Church before they attended the evangelistic meetings. Thirty five percent had their first contact through friends and relatives, and 3.6 percent mentioned the small groups. The religious background former 
members most frequently indicated was the Catholic Church (48.2 percent), 32.1 percent were unchurched people, and only 12.5 were Evangelical.

TABLE 7

AGE AND GENDER OF FORMER SDA MEMBERS

\begin{tabular}{lrrrrrr}
\hline & \multicolumn{2}{l}{ Male } & \multicolumn{3}{c}{ Female } & \multicolumn{3}{c}{ Total } \\
Age & $N$ & $\%$ & $N$ & $\%$ & $N$ & $\%$ \\
\hline $0-10$ & 0 & 0 & 1 & 100 & 1 & 100 \\
$11-20$ & 13 & 35.1 & 24 & 64.9 & 37 & 100 \\
$21-30$ & 6 & 40.0 & 9 & 60.0 & 15 & 100 \\
$31-40$ & 2 & 66.7 & 1 & 33.3 & 3 & 100 \\
$41-50$ & 0 & 0 & 2 & 100 & 2 & 100 \\
\hline Total & 21 & 36.2 & 37 & 63.8 & 58 & 100 \\
\hline
\end{tabular}

TABLE 8

FACTORS THAT ATTRACTED FORMER BELIEVERS TO THE SDA CHURCH

\begin{tabular}{lcclcclcc}
\hline First contact & $N$ & $\%$ & Background & $N$ & $\%$ & Attraction & $N$ & $\%$ \\
\hline $\begin{array}{l}\text { Evangelistic } \\
\text { meetings }\end{array}$ & 31 & 55.4 & Catholic & 27 & 48.2 & SDA beliefs & 27 & 48.2 \\
$\begin{array}{l}\text { Friend and } \\
\text { relatives }\end{array}$ & 20 & 35.7 & Unchurched & 18 & 32.1 & Evangelist & 19 & 33.9 \\
$\begin{array}{l}\text { Small groups } \\
\text { Fthers (radio, }\end{array}$ & 2 & 3.6 & Evangelical & 7 & 12.5 & $\begin{array}{l}\text { Fellowship of } \\
\text { believers }\end{array}$ & 10 & 17.9 \\
$\begin{array}{l}\text { TV and } \\
\text { literatures) }\end{array}$ & 5.3 & $\begin{array}{l}\text { Others (SDA, } \\
\text { Spiritualism) }\end{array}$ & 4 & 7.2 & & & & \\
\hline Total & 56 & 100 & Total & 56 & 100 & Total & 56 & 100 \\
\hline
\end{tabular}


The largest group (48.2 percent) indicated that the truth of the church's teachings attracted them the most. The witness of members' lives (17.9 percent) and the charisma of the evangelist ( 33.9 percent) also influenced them toward Adventism.

A comparison with the factors which most influenced the decision to join Adventism confirms Dudley's discovery that 'those new members who united with the church because of the truth and beauty of its teachings tended to regard themselves as stronger than those who joined because of the charisma of the minister/evangelist."'

Table 9 shows that one-third of the backsliders interviewed did not mention any specific crisis that stimulated interest in spiritual matters, while 28 percent mentioned Bible studies as the main cause of their interest. A comparison with the disruptive events in the experience of members who stayed longer in the church reveals that new members who indicated personal crisis, death, or illness of a close friend or relative tended to be more strong in spiritual life than those who did not mention any specific crisis before joining the Adventist message. Those who did not experience crises also tended to be more irregular in their attendance at the church services.

Table 10 indicates that 85.7 percent of those responding described the kind of instruction received before baptism as satisfactory and very thorough (more than they had expected). Only 14.2 percent regarded the instruction as inadequate and very inadequate (they felt deceived). Concerning the time spent in preparation before joining the church, 58.9 percent studied the church's teaching less than two months. About 35.7 percent spent

'Dudley and Cummings, 133. 
from three to eleven months examining Adventist beliefs.

TABLE 9

CRISES THAT INFLUENCED FORMER BELIEVERS TO BE RECEPTIVE TO SPIRITUAL MATTERS

\begin{tabular}{llc}
\hline Crises & $N$ & $\%$ \\
\hline Nothing & 16 & 30.2 \\
Begun Bible Studies & 15 & 28.3 \\
Emptiness & 4 & 7.5 \\
World conditions & 4 & 7.5 \\
Emotional & 3 & 5.7 \\
Others & 14 & 20.8 \\
\hline Total & 56 & 100 \\
\hline
\end{tabular}

When a comparison was made between the time of study before baptism and their frequency of attendance at church services and liberality after baptism, it was found that people who studied less than two months tended to be more irregular in church attendance and giving of tithes and offerings than those who studied from three to eleven months. This, however, does not mean that all people must be forced into the same mold. Although Ellen White does not define a specific set of time for baptismal preparation, she does stress the need for a through preparation on the part of candidates for baptism. ${ }^{1}$ Besides, evidence of thorough conversion and practicing the truth needs to be carefully considered before baptism. ${ }^{2}$

'White, Evangelism, 308.

${ }^{2}$ Ibid. 
TABLE 10

\section{LENGTH AND LEVEL OF INSTRUCTION RECEIVED BY FORMER MEMBERS BEFORE JOINING THE CHURCH}

\begin{tabular}{lcclcc}
\hline Instruction & $N$ & $\%$ & Time of study & $N$ & $\%$ \\
\hline Very thorough & 19 & 33.9 & Did not study & 1 & 1.8 \\
Satisfactory & 29 & 51.8 & Less than 2 months & 33 & 58.9 \\
Inadequate & 4 & 7.1 & 3 to 11 months & 20 & 35.7 \\
Very inadequate & 4 & 7.1 & 1 to 3 years & 2 & 3.6 \\
\hline Total & 56 & 100 & Total & 56 & 100 \\
\hline
\end{tabular}

As shown in figure 3, the connection between church attendance and apostasy is seen in the fact that most of respondents (66.1 percent) rated their frequency at the church services as occasional and irregular, while 34 percent mentioned that they were frequent and very regular. It would appear that church attendance is important to remaining in the church. ${ }^{1}$ Of those who were in the process of leaving the church, 52.8 percent of the respondents were not fully involved in any fellowship group or small-group activities for personal intimacy and spiritual growth.

A curious double standard is seen in figure 4 . When people united with the church, they did not suggest personal need or social satisfaction as causes for joining. Most of them related church membership with the religious values and the beauty of SDA beliefs. When they left, however, they were more likely to blame a breakdown in personal relationships and social pressure. A comparison with the factors in the decision to leave

\footnotetext{
'Alan F. Harre, Close the Back Door: Ways to Create a Caring Congregational Fellowship (St. Louis, MO: Concordia Publishing House, 1984), 34.
} 
the church revealed that a greater participation in small groups tended to decrease the percentage of social pressure from friends and relatives (the strongest factor mentioned toward apostasy) and the lack of fellowship.

Figure 5 shows that the vast majority of former members $(71.4$ percent $)$ were not participating in personal witnessing and ministries so that they could feel included and make a meaningful contribution to the church program. It appears that the concept of involving members in ministry based on their gifts is widely accepted in the SDA church, but the implementation reported by backsliders in Teresina appears to be mediocre or poor.

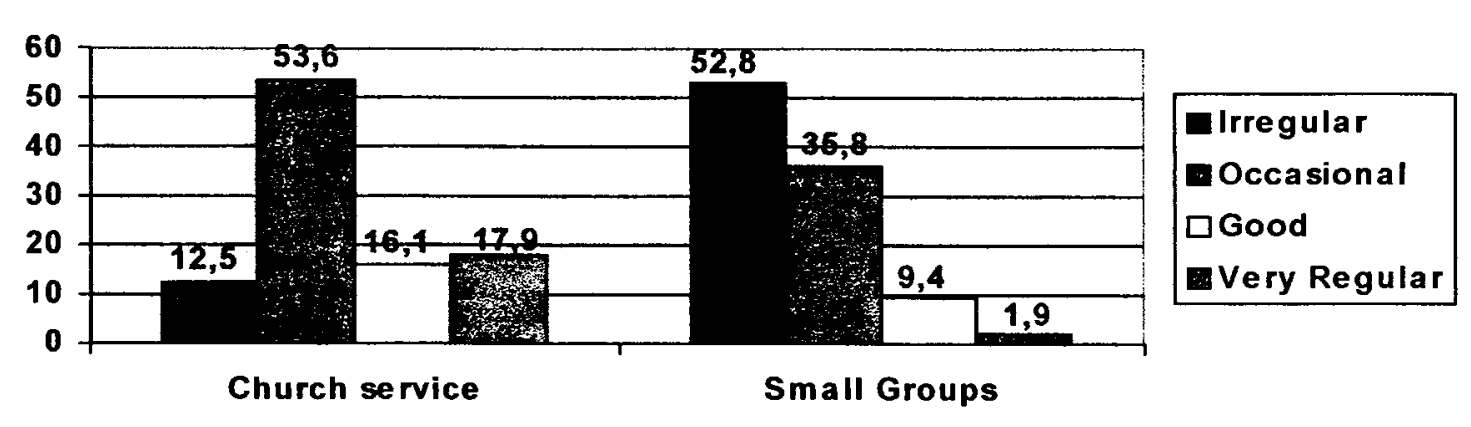

Figure 3. Rating church participation of former members before they left the church.

Of those on the way out of the church, 66 percent reported that they were not practicing Christian stewardship of their money. This suggests that they were not thoroughly educated in regard to these essential matters. 


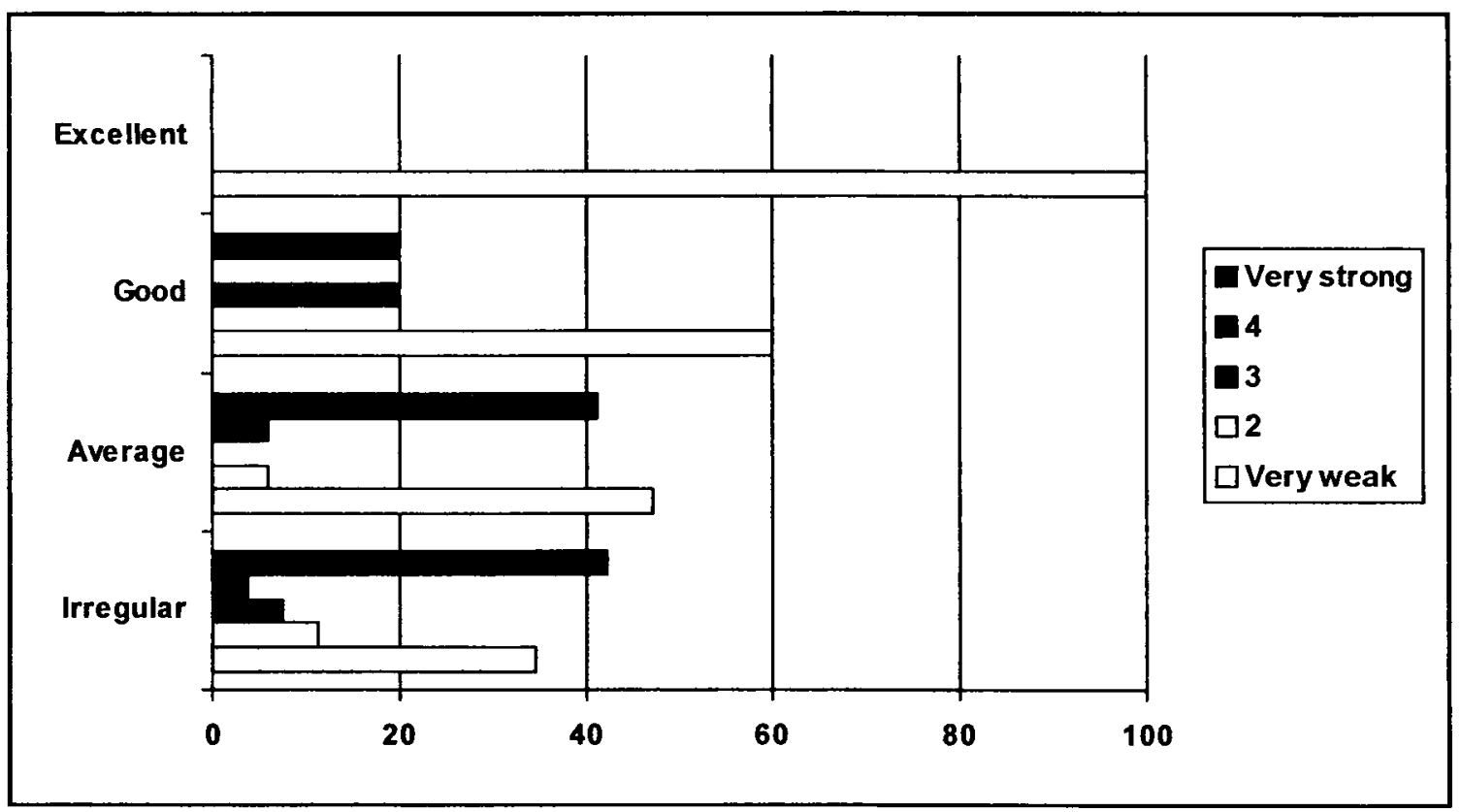

Figure 4. Correlation between small group participation and social pressure experienced by former members.

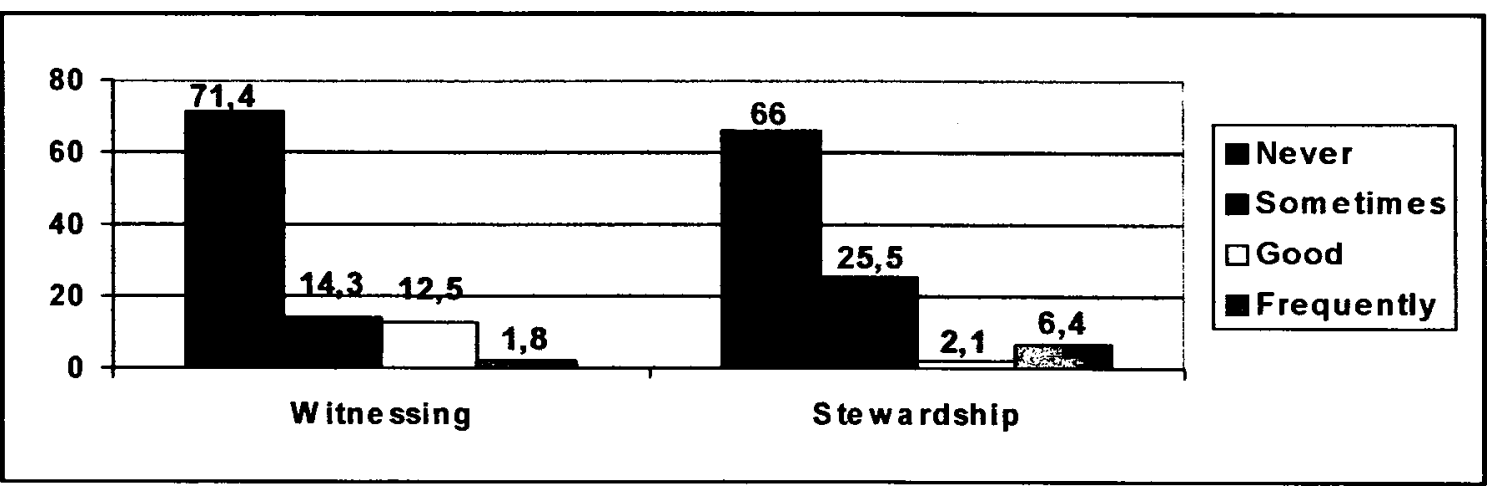

Figure 5. Level of witnessing and giving practices among former members.

Comparing their participation in witnessing with their liberality in tithes and offerings provides opportunity to measure the relative strength of the various discipleship methods in this situation. It is not surprising that people who had "excellent" participation in missionary activities also tended to be "frequent"givers (see fig. 6). Ellen White connects these two areas, affirming that "spiritual labor, toil, and burden-bearing, is what will give strength to 
church of Christ."1 She also points out that "every effort made for Christ will react in blessing upon ourselves,"2 while "the very act of giving expands the heart of the giver, and unites him more fully to the Redeemer of the world."3

A careful look at the reasons people gave for dropping out of church within six months following their acceptance into formal membership through baptism shows that some people simply suffered an erosion of interest. Once the initial enthusiasm of involvement in the church has passed, new disciples are not likely to continue attending unless they feel a part of the overall life of the church and believe that their participation is important to the church.

Figure 7 (part 1 and 2) indicates that among the factors influencing personal decisions to leave, 37 percent mentioned social pressure from non-Adventist friends or relatives, whereas 26 percent reported lack of fellowship. Only 14 percent complained about being mistreated by the members. They had been received into membership, but had never felt they were accepted into the fellowship circle of the church. Interestingly, they accepted all the church's teachings (64.3 percent), did not regard Adventist standards as too strict (65.3 percent), and did not consider the church programs as irrelevant to their lives (54 percent). In other words, doctrinal conflict did not emerge as a reason for leaving the church.

${ }^{1}$ White, Christian Service, 271.

${ }^{2}$ Ibid., 270.

${ }^{3}$ Ellen G. White, Counsels on Stewardship (Washington, DC: Review and Herald Publishing Association, 1940), 347. 


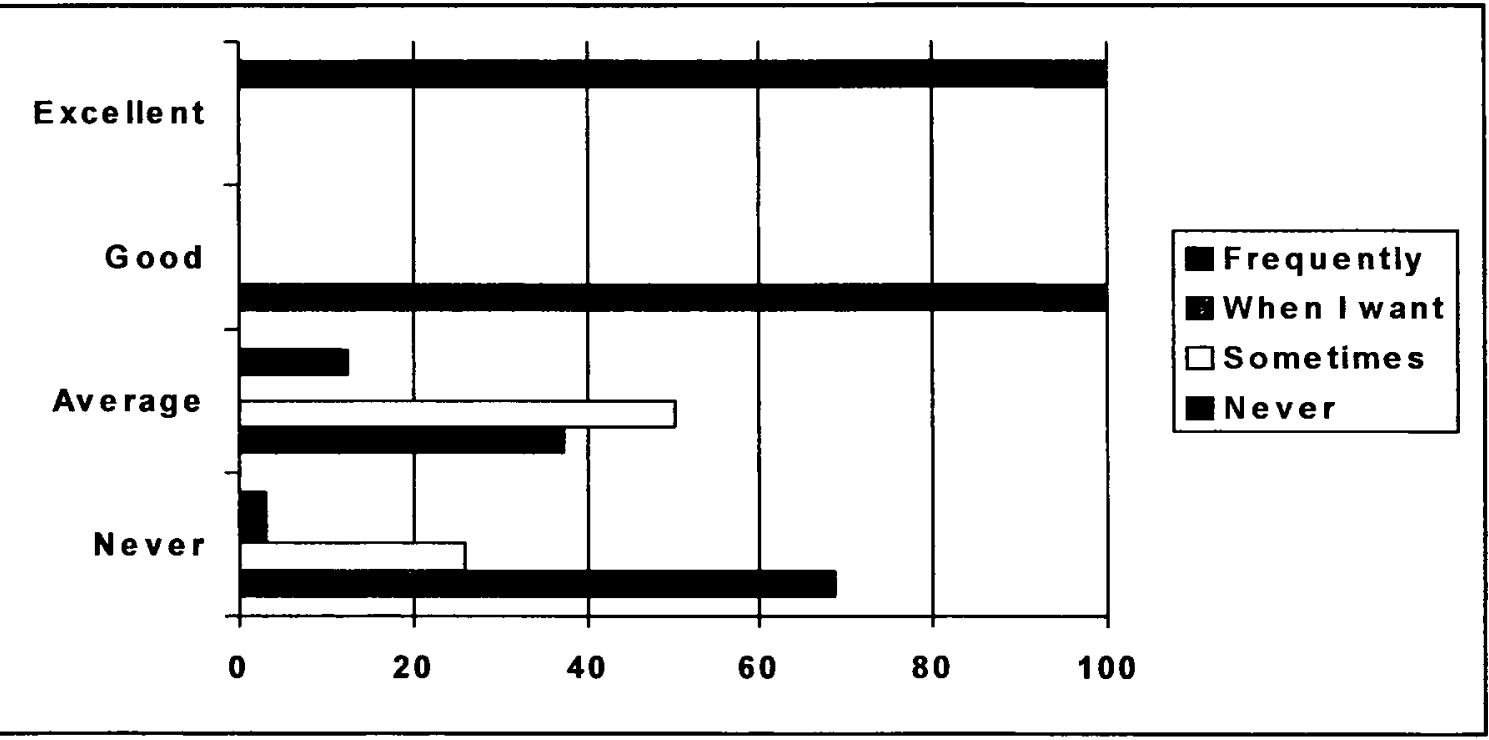

Figure 6. Correlation between activities and giving habits of former members.

However, when respondents were asked to state briefly the main thing that could have been different and would have encouraged them to remain in the SDA church, the majority answered that friends or friendship ties could have helped them stay. About $\mathbf{1 9 . 8}$ percent complained that they did not feel they were loved, accepted, or wanted by other members of the congregation. Responses also listed personal considerations, such as lack of support or opposition from other family members (12.6 percent), lack of visitation in their homes by church members ( 5.4 percent), lack of activities in the church ( 3.6 percent), changes in work schedules (3.6 percent), and drug addiction (3.6 percent).

Most of those interviewed ( 85 percent) recognized the effort made by the church to reclaim them through pastoral and member visitation after they stopped attending the church. A full 57 percent appeared optimistic about the chances of their return to the SDA church. When asked what obstacle blocked renewed membership, about 48 percent 
indicated that no real obstruction existed. Others mentioned family (12.6 percent), lack of interest (3.6 percent), work on Sabbath (1.8 percent).
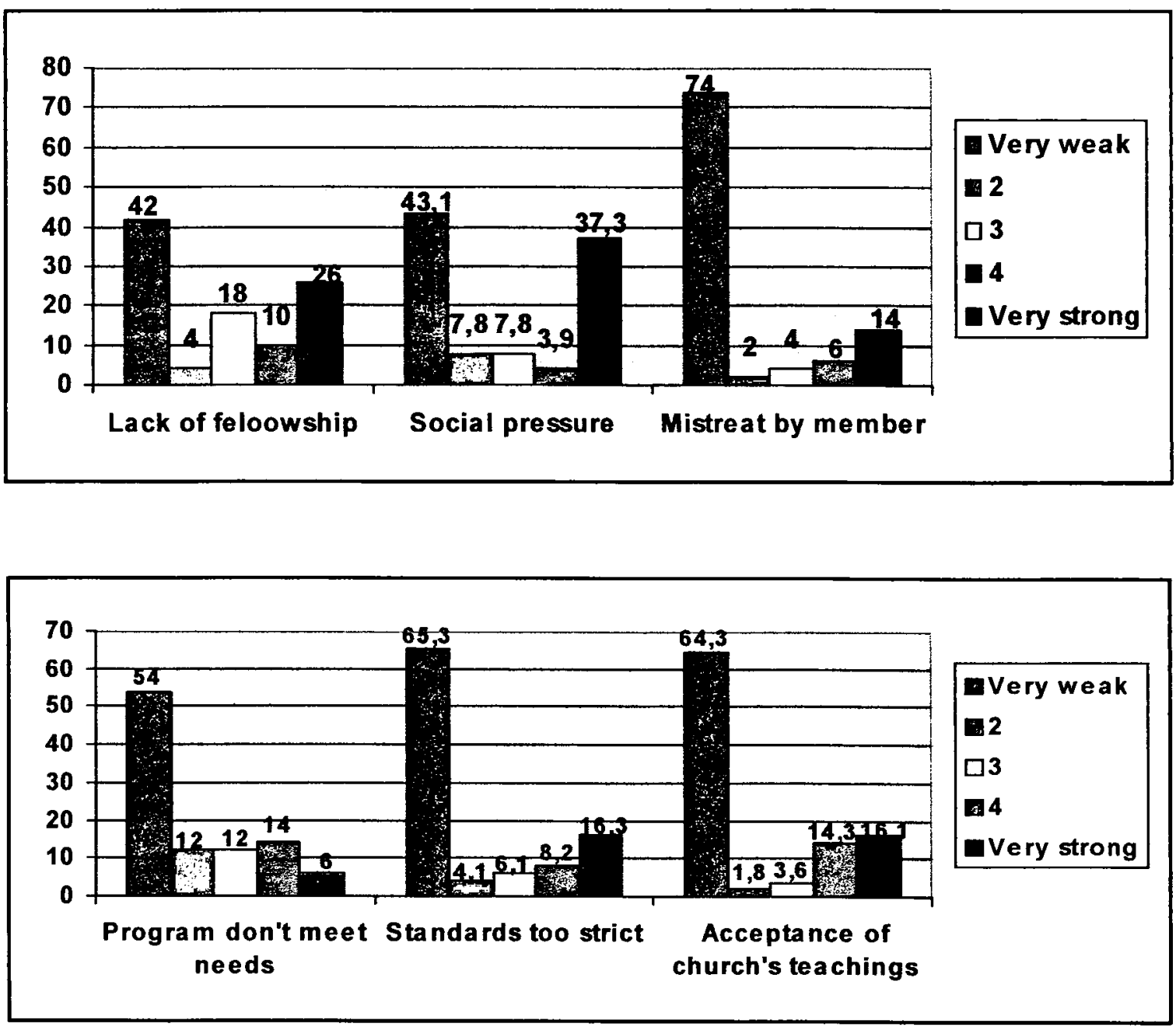

Figure 7. Factors influencing the decision to leave the church according to former members.

\section{Implications of the Information Obtained}

This section attempts to assess and define the implications of the information obtained. It is evident that the deficiency must be filled if making self-initiating, reproducing, fully devoted followers of Christ is to become the new reality of the Adventist Church in 
NBUM. First, the study deals with the symptoms of the discipleship gap in the current reality, then looks at the factors that contributed to this gap.

An evaluation of the symptoms of discipleship deficit is presented in table 11 .

TABLE 11

SYMPTOMS EXPERIENCED BY IMMATURE MEMBERS

\begin{tabular}{ll}
\hline \multicolumn{1}{c}{ Symptoms } & \multicolumn{1}{c}{ Notes } \\
\hline $\begin{array}{l}\text { 1. Unaware of the meaning and duties } \\
\text { of discipleship instead of becoming } \\
\text { equipped disciples. }\end{array}$ & $\begin{array}{l}\text { They considered their baptismal instruction good in } \\
\text { terms of depth and length. However, information does } \\
\text { not automatically leads to transformation. They need to } \\
\text { be involved in a process of continual instruction. }\end{array}$ \\
$\begin{array}{l}\text { 2. Lack of progress in their } \\
\text { spirituality instead of an intentional, } \\
\text { structured, and disciplined spiritual } \\
\text { growth. }\end{array}$ & $\begin{array}{l}\text { Many of them did not know how to study the Bible to } \\
\text { meet their own spiritual needs. Many of them needed } \\
\text { more instruction about spiritual formation. }\end{array}$ \\
$\begin{array}{l}\text { 3. Passive recipients instead of } \\
\text { proactive ministers. }\end{array}$ & $\begin{array}{l}\text { They were poorly taught about their spiritual gifts, } \\
\text { stewardship, missionary work, and were not involved in } \\
\text { roles and tasks of service. }\end{array}$ \\
$\begin{array}{l}\text { 4. Inactive personal witness instead of } \\
\text { sharing the faith. }\end{array}$ & $\begin{array}{l}\text { They did not know the concepts of mission, friendship } \\
\text { evangelism, etc. and therefore, they did not build } \\
\text { intentional relationships to share faith. }\end{array}$ \\
$\begin{array}{l}\text { 5. Stranger to the church fellowship } \\
\text { instead of integrated in fellowship. }\end{array}$ & $\begin{array}{l}\text { Although the program of small groups had been } \\
\text { established, many were not actively participating. They } \\
\text { were not part of the inner circle of the church. }\end{array}$ \\
\hline
\end{tabular}

\section{Factors Contributing to the Deficit}

Several factors contribute to this discipleship deficit or gap. The most important are improper equipping, improper disciple making focus, no clear pathway to maturity, and imbalanced or incomplete models of discipleship. 


\section{Improper Equipping}

The ministerial students who interviewed the backsliders were given a set of questions to guide their observations regarding the physical setting of the project, its activities and events, as well as people's behaviors. Eleven students noted the lack of pastoral involvement in the training and equipping of the new disciples. They found that few pastors make discipleship a top priority within their ministry and that behind the interruption in most follow-up programs (sponsorship and small groups) was a lack of pastoral supervision, as well as of visionary leadership focusing on the mission of the church.

Perhaps this research finding did not properly consider the challenges produced by job overload of NBUM pastors, who provide supervision to an average of seven churches in each pastoral district. Nevertheless, the most important responsibility of leaders is to equip God's people to do ministry (Eph 4:11-13). Biblically, church leaders are not to take it upon themselves to do the ministry of the church but should encourage the congregation to do it. They are to train "God's people for works of service, so that the body of Christ may be built up." According to Barna, the pastor is the catalyst behind the commitment to spiritual growth. ${ }^{1}$ Pastors provide vision and motivation to the congregations, general direction for the process, and ensure that the resources are available to carry on the ministry. ${ }^{2}$

However, many leaders have been diverted from their primary job description of training/equipping to focus on the traditional roles of conducting worship, providing

\footnotetext{
${ }^{1}$ George Barna, Growing True Disciples (Colorado Springs, CO: WaterBrook Press, 2001), 116.

'Ibid., 117.
} 
pastoral care, and involving themselves in building projects. The apostles faced the same temptation during the early stages of the church's life (Acts 6:1-6). The solution is to make pastors coaches: "They participate in ministry but see their primary responsibility as that of training and equipping others so that their ministry is multiplied."1

\section{Improper Disciple-Making Focus}

In recent years Adventists churches in NBUM have experienced the addition of large numbers of new converts. The accession rate in the Adventist church by baptism has been rapidly increasing. At the same time, denominational bookstores are full of books on personal and small group activities describing various approaches, strategies, and lessons to help Christians grow. But those tools, as helpful as they are, address only one aspect of a total disciple-making strategy for the local church. Although great progress has been observed in the church ministries, one of the weaknesses in the Adventist system is that baptism tends to become an end in itself. Mass evangelistic crusades are traditionally reported and acclaimed as successful by the number in attendance and the number of baptisms recorded.

Perhaps the elements of discipleship in Matt 28:19, 20 needs to be carefully analyzed for a better understanding of what true discipling involves. The end product of evangelism and the Great Commission is not baptism but a mature, growing disciple who is able to reproduce and share Christ with others. True discipleship produces holistic personal transformation, not only assimilation into a community of church members.

${ }^{1}$ Kent R. Hunter, Foundations for Church Growth: Biblical Basis for the Local Church (Corunna, IN: Church Growth Center, 1984), 204. 
G. E. Autrey affirms that "incomplete evangelism is the most expensive failure of the church." What does this mean? He answers: "Evangelism which stops with conversion is incomplete and has not accomplished its full intended purpose." In another book, The Disciple Making Pastor, Hull affirms that "the impetuousness of human nature and cultural pressure to get quick results have caused pastors to take every short cut," and that "we have sacrificed disciple making on the altar of cultural success, ego gratification, and immediate need." "3 Thus, a clear, measurable, and new definition of spiritual success is needed. To figure out in practical terms what God expects of pastors and leaders, to assess how those expectations could be measured, or to determine what should be done to improve pastors' performance with respect to those desired outcomes-this is the task before us.

Ellen White has argued this point. She showed that pastors "should not be at all satisfied with their success until they can, by their earnest labors and the blessing of God, present to Him serviceable Christians, who have a true sense of their responsibility. ${ }^{94}$ In other words, pastors should not be satisfied with the mere number of members, but in developing serviceable Christians as well.

\section{No Clear Pathway to Maturity}

Discipleship does not happen simply because a church exists. It occurs when there is 1959), 142.

${ }^{1}$ G. E. Autrey, Basic Evangelism (Grand Rapids, MI: Zondervan Publishing House,

${ }^{2}$ Ibid.

${ }^{3}$ Bill Hull, The Disciple Making Pastor (Old Tappan, NJ: Fleming H. Revell Company, 1998), 23.

${ }^{4}$ White, Evangelism, 345, 351. 
an intentional and strategic thrust to facilitate spiritual maturity. Clearly, the spiritual growth of many new Christians is hindered by the lack of detailed assistance and guidance from their churches. Greg Ogden, in his book Transforming Discipleship, affirms that "it is rare to find a church with a well-thought-out, easy to grasp process or path onto which people can get if they want to become self-initiating, reproducing, fully devoted followers of Christ." With a burdened heart he writes: "We have no destination in mind, and so therefore no road in which people can walk even if they want to understand the implications of discipleship."2

Discipleship is not a solo adventure. People are more likely to grow spiritually when their church is intensively focused on bringing them to maturity in Christ. A pathway system moves people from spiritual prebirth to Christian maturity (Matt 28:19-20; Eph 4:12-13; Col 1:28;2:6, 7). This involves moving them from where they are (unbelief or immaturity), to where God wants them to be (spiritually mature). This pathway recognizes that people are at different places in their spiritual journey.

An example of a pathway is the model used in the Saddleback Church with progressing steps or stages necessary to make a disciple (Membership, Maturity, Ministry, Mission). This pathway or strategy is the thread that runs through all the programs of the church and not only ties them together but communicates the spiritual purpose of each, maximizing ministry energy. ${ }^{3}$ 204.

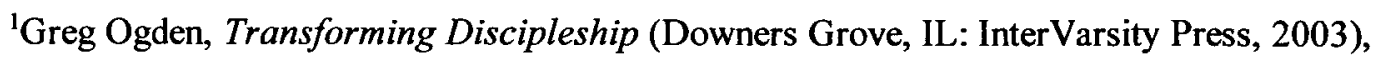

${ }^{2}$ Ibid.

${ }^{3}$ Malphurs, Strategy 2000: Churches Making Disciples for the Next Millennium, 24. 


\section{Unbalanced Models for Discipleship}

Four reasons have emerged from this research to explain some of the difficulties encountered in the discipleship models in the NBU:

1. Unfortunately, most small groups do well with fellowship but falter when it comes to facilitating transformation. Just being satisfied to involve new members in small groups without regard for the product is not enough. The problem is not the approach itself. Having small groups of people committed to helping one another grow can be incredibly effective. But greater life transformation through small groups in Teresina was not seen because there was a lack of training for facilitators, lack of purposeful selection of material to cover in a systematic manner, lack of a curriculum for helping new members grow, and absence of an accountability process.

2. Regarding the one-on-one approach to track spiritual development of individuals in the church, with one individual serving as the discipler and the other as the disciple, few churches researched had a life-changing mentoring or coaching program because such a process demands extensive knowledge of the qualities and capabilities of the coach as well as dedication and commitment. Few believers have been matched with a trustworthy and competent partner who could hold them accountable to specific and measurable goals. It is difficult to train people, even those who can do the job, to be effective mentors. It is also hard to prevent the mentoring process from becoming strictly a fellowship effort.

3. Because most of Teresina's dropouts ( 72 percent) were between 13 and 25 years of age, church leaders should objectively assess where the church will get the greater return on its evangelistic investment, in working for adults or dealing with young people. When the 
church focuses more energy and resources on resuscitating adults rather than nurturing children, it is missing the fact that positive change is easier and permeates much more deeply when people are young (Prov 22:6). Old habits are difficult to break. Thus, the youth should be carefully trained in the right direction because "the habits formed in youth will grow with the growth and strengthen with the strength."1

4. Discipleship has been defined as head knowledge rather than complete transformation. It has been assumed that if a church provides teaching events and programs such as study groups, seminars, reading groups, video curricula, Bible study in the Sabbath School, and Christian education classes, then new members will grow. Although all of these methods are certainly needed, discipleship is "an artful blend of what we know and what we do." ${ }^{2}$ There is a need to balance knowledge and application by dividing our time between teaching and demonstrating love in action-by involving and supervising new members in practical tasks.

\section{Meeting the Needs of the New Disciples in NB}

From the discussion of the symptoms of the discipleship deficit following evangelistic efforts and their underlying causes, a possible conclusion would state that, if the church is to grow, it must meet the basic needs of new members in their process of growth into Christ-like maturity and reproduction. Malcolm Knowles, in his book The Modern Practice of Adult Education, affirms that "the primary immediate mission of every adult

${ }^{1}$ Ellen White, Counsels to Parents, Teachers, and Students (Boise, ID: Pacific Press Publishing Association, 1943), 81.

${ }^{2}$ Barna, 31. 
educator is to help individuals satisfy their needs and achieve their goals." He uses Maslow's Hierarchy of Human Needs (survival, safety, love, affection, and belongingness, esteem, and self-actualization) to develop his thesis that "gratification for the needs on each level, starting with the lowest, frees a person for higher levels of gratification."2 Therefore, at least five basic needs of NB new members were identified in this survey. ${ }^{3}$

\section{Need of Food}

Spiritual babies, like natural babies, need to be fed regularly. Similar to the mother's milk, the spiritual nurture of the Scripture is essential to spiritual growth (1 Pet 2:2, 3). In his classic Celebration of Discipline, Richard Foster refers to study as a way to replace "old destructive habits of thought with new life-giving habits." ${ }^{\prime 4} \mathrm{He}$ emphasizes that "the mind will always take on an order conforming to the order upon which it concentrates." also deals with this issue in her book Steps to Christ. She says that "it is what we meditate upon that will give tone and strength to our spiritual nature."6

Newborn babies in Christ do not know how to feed themselves. They need to be fed in two ways. One is to teach them the Word; the other is to teach them how to dig for

${ }^{\mathrm{I}}$ Knowles, 23, 24.

${ }^{2}$ Ibid.

${ }^{3}$ Eims, 63-66.

${ }^{4}$ Richard J. Foster, Celebration of Discipline (New York: Harper Collins Publishers, $1978), 62$.

${ }^{5}$ Ibid, 63.

${ }^{6}$ Ellen White, Steps to Christ (Boise, ID: Pacific Press Publishing Association, 1956), 88. 
themselves. It is more than just handing a new believer a Bible study and saying, "Here, you need this for spiritual nourishment." Unless new converts learn how to study for themselves, they will be dependent on others for the rest of their lives.

\section{Need of Watchful Care}

New babies need protection. That protecting environment is the loving fellowship of other believers in a setting where they can be nurtured, cared for, and protected. New life is tender and fragile, and must be protected. In the same way new members need protection from false cults and a variety of attacks by the enemy. According to Eims, "people spreading the disease of false religion will show up at their door. The convert's old cronies will try to entice him back into the old paths. A former girlfriend will want to renew the relationship."1

The new disciples need authority figures to guide and direct them appropriately through life. These figures include parents and other significant leaders. The new disciples feel unsafe in their new situation, with new concepts, and many new people. Paul continued to undergo the pain of childbirth for his converts until Christ was formed in them (Gal 4:19). He prayed for the Corinthians that they would not do anything wrong (2 Cor 13:7).

\section{Need of Fellowship}

New members have been born into a family and need the fellowship of their brothers and sisters in Christ. Babies occasionally make messes, do foolish things, and may be somewhat of a bother. They need to be loved, affirmed, and accepted by significant members of their family. They need to belong to a group, attached by birth or adoption, as is

${ }^{1}$ Eims, 63. 
most significantly evidenced in the family system. ${ }^{1}$

Studies show that friendship and acceptance are some of the primary reasons people continue in a relationship with a church: "The most important reason people are involved in their church today is their friendships and relationships. When people drop out of church, the reason most given is not personal conflict in theology-it is that they did not feel a sense of belonging. They did not feel needed, wanted, or loved."2 It is vitally important that this "friendship principle" be taught in the church. The church needs to welcome those who have come in and get everyone coming into the church connected with others of common background so they can make friends.

\section{Need of Instruction and Participative Activities}

If spiritual babies are to develop a healthy and vibrant faith, they must give themselves to spiritual exercise and labor. As a father deals with his own children (1 Thess $2: 11$ ), the church needs to provide training to new believers on "how to" do things (1 Thess 4:1). Although cognitive instruction is important, learning comes through behavioral changes as well. New believers need to know how to get rid of the slavery of ingrained habits by cultivating the spiritual disciplines. They need to know how to be faithful stewards, to learn how God has gifted them and how to best use their gifts. Overall, they need to be immediately involved in participation, for "the spiritual growth and development of a new 2000), 97.

'Stephen A. Macchia, Becoming a Healthy Church (Grand Rapids, MI: Baker Books,

${ }^{2}$ Roy M. Oswald and Speed B. Leas, The Inviting Church: A Study of New Member Assimilation (New York, NY: Alban Institute, 1987), 58. 
member, like that of a new babe, comes from flexing the muscles in exercise."

In his lectures about discipleship, Gary Cobb, coordinator of Billy Graham's followup crusades, used the newborn baby analogy, pointing out that when parents bring a baby home from the hospital, the obstetrician is no longer directly involved or available. In the same way, he suggested that when a person comes to Christ at an evangelistic meeting, and the evangelist is no longer present, the church needs to find a "spiritual" parent or a mentor to help that person grow. ${ }^{2}$

\section{Need of Maturity}

The time comes when the new members, well instructed and spiritually strong because of their involvement in service, are taught to stand alone without their discipler or minister. Therefore, they need to reach spiritual stability in order to deal with their mistakes and failures and disappointments without losing their faith. They need to have a mental attitude of trust in God and in His promises in such a way as to recover from seasons of temptation, grief, and trial. They also need to be self-actualized in the sense of reaching their full potential so that one day it can be said of them that they "served God's purpose" (Acts $1: 36){ }^{3}$

Every parent understands this principle. Most adults find they quickly grow up when they become parents because their focus is no longer on themselves but on a dependent

${ }^{1}$ White, Evangelism, 356.

${ }^{2}$ Gary Cobb, course lecture, "Empowering New Believers," Billy Graham School of Evangelism, June 16-18, 2004.

${ }^{3}$ Eims, 76. 
infant. So it is with spiritual growth. The best way to grow spiritually is to become a father or mother in the Lord. As members turn their energies to bringing other people to Christ or helping them grow in the Lord, they find their own faith blossoms. Now the disciples multiply themselves in new disciples by carrying forward the services of the church and bearing responsibilities. 


\section{CHAPTER VI}

\section{A DISCIPLESHIP MODEL FOR NORTHEAST BRAZIL}

This chapter presents a proposed model for discipleship appropriate for Northeast Brazil. The chapter begins by describing the model with the elements and structures necessary for the disciple-making process. The second part of the chapter describes how the model should be implemented by breaking up the task of making disciples into manageable units.

\section{Description of the Model}

This model is designed to help (1) existing churches to make adjustments to their processes and methods to make disciples and (2) for pioneer situations in the context of theological field training. It may also be used to prepare any local church in NB for effective evangelism, regardless of size or location. The following advantages will ensue: evangelistic tasks are defined, relational groups are identified, leadership issues are raised, and a pathway to maturity is defined.

As a way for understanding this holistic disciple-making model, three promising elements from corporate models are borrowed:

1. Wesley's Interlocking Groups System combines group techniques to construct a chain of personal spiritual improvement. Like Wesley's system, this model uses “field 
preaching" or public meetings as an entry point, and some structures such as Class Meeting, Bands, and the Society for the incorporation of new members. ${ }^{1}$

2. The approach of moving people from "Hostile to Spiritual Things" to "Balanced Christian Life," adapted from the Willow Creek Community Church, though different philosophies of ministry, strategy, and structures.

3. The strategy of moving people from large to mid-size group and then to a small group is taken from the Pantego Bible Church. This is especially seen in the fourth step-the establishing phase of the discipleship model for NB.

One of the basic goals of this model is to provide balance in decentralization in the areas of evangelism, assimilation, and apprentice making. Evangelism will occur at the level of every cell as well as in celebration events. Assimilation will occur in cell groups as well as in membership classes. Apprentice development will occur in cells as well as in special classes. The only exceptions are coping with crises and membership care, which are supposed to be dealt with in nurture cells in a decentralized care system, instead of a centralized professional clergy.

The vision of any church or organization always fades with time unless it is reinforced. The visual image to be used in order to call attention to the vision to be communicated will be that of a butterfly (see figure 8 ). ${ }^{2}$ Comparing the Christian life to a trip around the two three-point or cornered wings, the design illustrates the importance of

${ }^{1}$ See chapter 4.

${ }^{2}$ Some elements of this figure was adapted from a church planting model used by David W. Shenk and Ervin R. Stutzman in Creating Communities of the Kingdom: New Testament Models of Church Planting (Scottdale, PA: Herald Press, 1984), 159. 
a disciple`s involvement in two spheres of life-body and community. Both priorities-outreach and inreach-must be pursued in balance if we are to grow in Christian maturity.

Within the "Body" (right wing), the disciple grows in commitment to Christ through fellowship, stewardship, and service. But discipleship is incomplete without the disciple's involvement in winning new disciples through friendship, witness, and the challenge to commitment. Thus, disciples are also involved in the "Community" (left wing) through the three essential elements in effective evangelism which are the "3Ps" (Presence, Proclamation, and Persuasion).

Disciples often get stuck at the second corner of the left wing and at the sixth corner, on the right wing, becoming in ineffective disciples and/or disciple makers. Besides, there is a recognition that this spiritual journey involves a process, which implies that people may experience a personal crisis along the stages with apparent loss of faith and disloyalty to church. ${ }^{1}$

For the developmental process to achieve its potential, disciples must be motivated to diligently pursue complete spiritual maturity-which, by definition, is beyond human grasp. Thus, the model requires the use of motivators, such as the Bible's admonition for believers to engage in the endless pursuit of spiritual maturity, the establishment of clear expectations, the identification of measurable goals, and the celebration of personal growth.

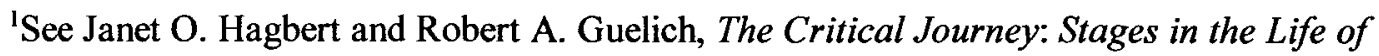
Faith (Salem, WI: Sheffield Publishing Company, 1995 ), 93-109. 


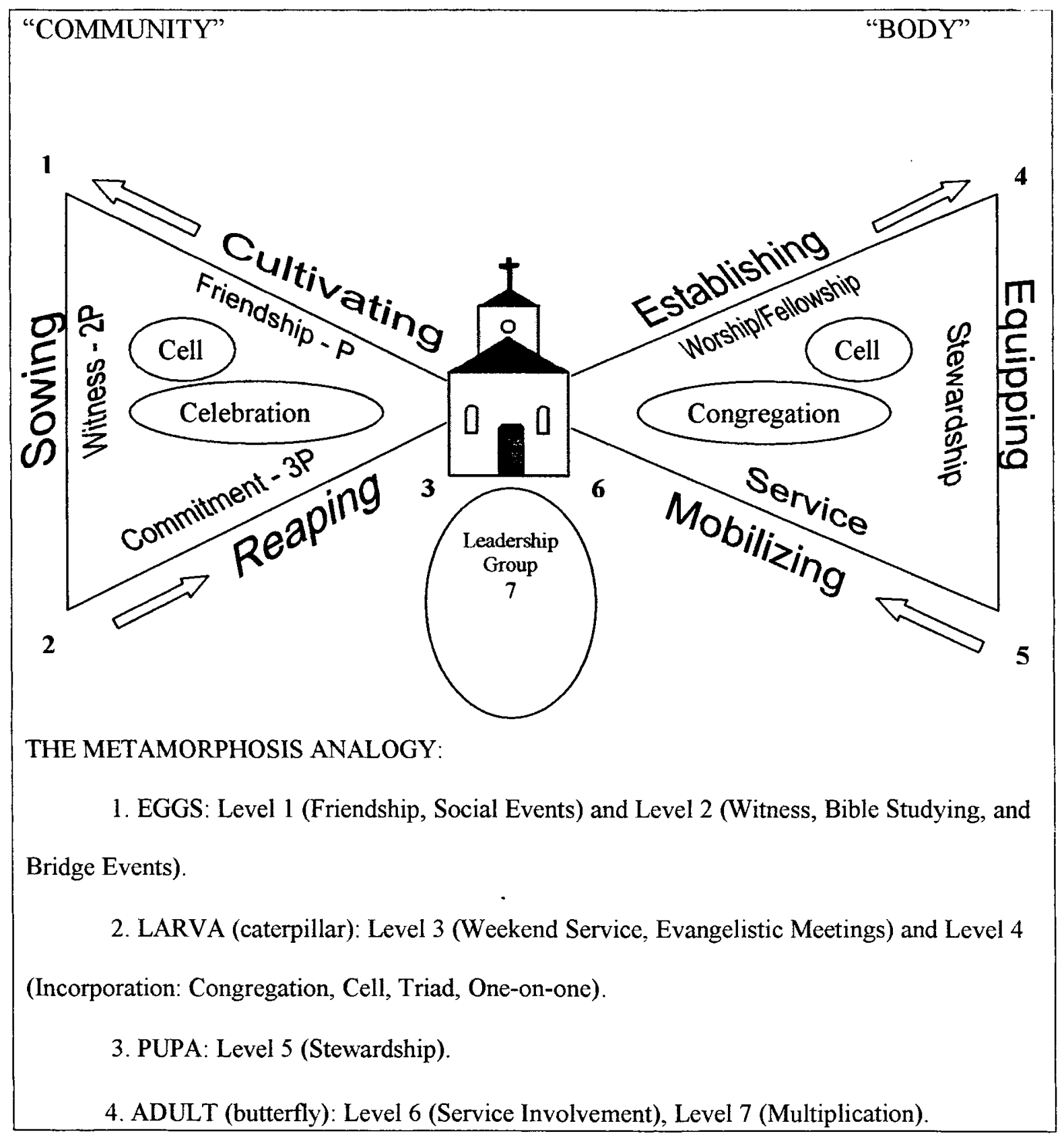

Figure 8. The Transformational Model to Make Disciples 
The butterfly's life cycle and metamorphosis, passing through four quite distinct stages (eggs, larva, pupa, and adult), suggests the process of moving people from spiritual prebirth to Christian maturity (Eph 4:12-13; Col 1:28;2:6-7). Christian maturity is regarded in this model as a lifelong pursuit, a journey rather than a specific destination that one may reach and then dismiss.

The structures of cell, congregation, and celebration are portrayed as the spots on the wings. They suggest a developmental plan that incorporates mass education (evangelistic meetings and classroom lessons), relational experience (cell groups), and one-on-one attention (mentoring). The system relies on multiple communication methodologies: lecture, discussion, visual media, literature, etc. This multitrack approach is necessary because people have different learning styles and because using a variety of methods reinforces both the process and the message.

The thorax, which bears the two wings, is the local church-the converging point of the inward and outward activities and the discipleship heart. The importance of the local church to the discipleship model is shown in the areas of recognition, development, and use of spiritual gifts; growth of Christian love; mutual sharing and involvement in one another's lives; unification of the body in fellowship and service; maintenance of Christian values; and spreading the gospel.

The abdomen with its reproductive system represents the selected training group where the leadership is equipped for ministry roles. Finally, the biblical picture or analogy that would help capture a vision for personal discipleship will be that of Barnabas (Acts 
$9: 27 ; 11: 24-26 ; 13: 2 ; 15: 35-39)$. For corporate discipleship, the model will be that of the Ephesian church (Acts 19; 20:13-36; Eph 4; Rev 2:1-7).

After this general introduction comes a description of the outreach (left wing), the inreach (right wing), and the structures of the model.

\section{Outreach Components}

The "Transformational" model uses three essential ingredients of evangelism to identify and categorize the evangelistic tasks of a local church: Presence, Proclamation, and Persuasion (see figure 9). It assumes evangelism as organic-much more like farming than selling. Because the Bible consistently employs an organic (1 Cor 3:5-9; John 4:3538; Matt 13:3-8) rather than a mechanical model to explain how God draws a person to Himself, this model divides evangelism into three phases: cultivating, sewing, and harvesting. ${ }^{2}$

This model also takes for granted that in a new, unreached mission field, evangelism usually begins with proclamation, moves to persuasion, and then, as decisions are solidified and converts grow, the gospel becomes a visible presence. But once a thriving church is established, the starting point for evangelism increasingly shifts from proclamation to presence (relational evangelism).

'This definition embraces the "3P" definition advocated by Church Growth and presented by Peter Wagner in his book Strategies of Church Growth (Glendale, CA: Regal Books, 1980), 10.

${ }^{2} \mathrm{~A}$ fourth one could be added: multiplying. However this phase is considered as part of the left wing of the model. 


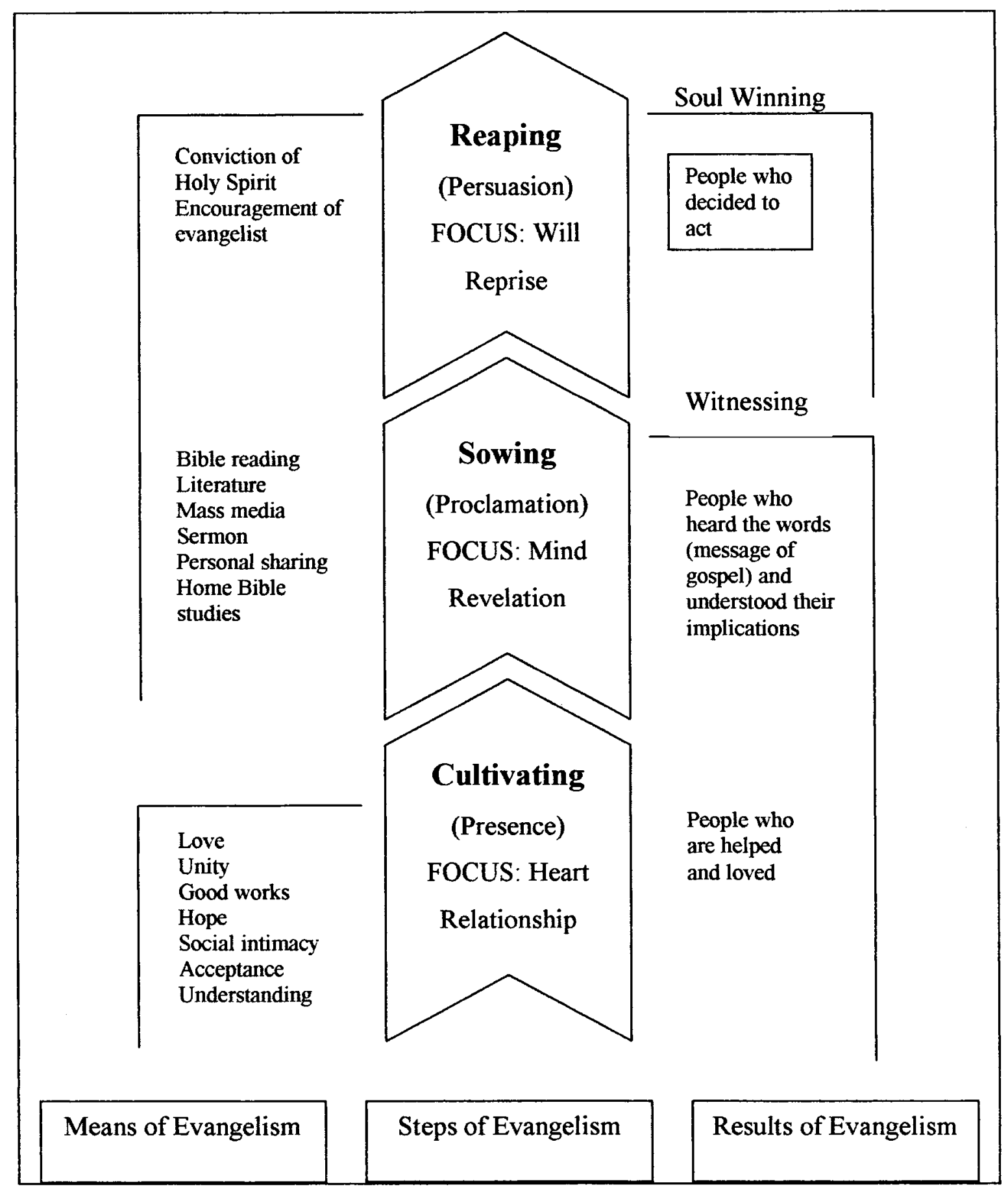

Figure 9. The Spiritual Decision Process. Adapted from Joe Aldrich, Lifestyle Evangelism, 23. 


\section{Cultivating through Presence Evangelism}

William Carr Peel and Walt Larimore explain that cultivation focuses on the soil of the human heart, which includes addressing emotional barriers. ${ }^{1}$ Christian presence reduces moral evil, dispels ignorance, and demonstrates the love and righteousness of God through an alternative lifestyle (Matt 5,6,7). When Christians express their love and faith in committed relationships with unbelievers, the faith is shared and the way is shown in a spontaneous evangelism. ${ }^{2}$

Pointer explains that the church, like Christ Himself, has to become incarnate before it can speak. ${ }^{3}$ Through Christian presence, a relationship of trust and openness with those who hear the gospel is established because presence gives relevance and credibility to proclamation.

According to Wagner, evangelistic success is measured in terms of how many people are helped through the efforts of Christians. "Compassion becomes the end for evangelistic work."

${ }^{1}$ William Carr Peel and Walt Larimore, Going Public with Your Faith: Becoming a Spiritual Influence at Work (Grand Rapids, MI: Zondervan, 2003), 23.

${ }^{2}$ Pointer, 78.

${ }^{3}$ Ibid., 133.

${ }^{4}$ C. Peter Wagner, Frontiers of Missionary Service (Chicago: Moody Press, 1971), 132. ${ }^{\text {s Ibid. }}$ 


\section{Sowing through Proclamation Evangelism}

The planting phase addresses intellectual barriers-misconception, misinformation, and ignorance about God and Christian faith. ${ }^{1}$ Proclamation is concerned with the content and communication of the gospel message. While priority will be given to activities that equip and use the ordinary church members for spontaneous evangelism among the network of their relationships, other systematic evangelistic activities, such as wellprepared visitation and Bible lesson distribution, home Bible studies, and student missions, complement the task.

Here communication becomes the end for evangelistic work. Success is measured in terms of how many people are involved in Bible studies, listening to a certain radio broadcast, or reading a certain piece of evangelistic literature. $^{2}$

\section{Reaping through Persuasion Evangelism}

The harvesting phase focuses on a person's will and its resistence to make a decision to trust Jesus. Aldrich rightly observes that the heart was addressed in the building up of a relationship (presence), and the mind was addressed through the communication of revelation (proclamation). Now an appeal to the will (persuasion) is given in anticipation of a response. ${ }^{3}$

'Peel and Larimore, 23.

${ }^{2}$ Wagner, 132.

${ }^{3}$ Joe Aldrich, Lifestyle Evangelism (Sisters, OR: Multnomah Publishers, 1993), 77. 
There are at least five elements in persuasion: personal relationships, elementary instructions, a call to commitment, an initiation rite, and early incorporation. ${ }^{1}$ With the initiation rite and incorporation of the new convert, the process of persuasion is complete. Nevertheless, persuasion evangelism evaluates success in terms of conversions or how many persons previously without Christ and without hope in this world committed their lives to Him and became members of the household of God.

The bottom line of this " $3 \mathrm{P}$ " wing is that making disciples through presence, proclamation, and persuasion should lead through "front door" and "side door" activities. ${ }^{2}$

\section{Inreach Components}

As a person is helped to begin a spiritual journey from salvation to maturity, it is important to realize that failure is part of the process. As said before, new believers experience setbacks morally, spiritually, and emotionally-as do more mature believers.

After this consideration, the best way to deal with spiritual nurture is to consider the five core experiences evident in the church's early days as described in Acts 2:42-47: learning, worship, fellowship, stewardship, and service. These five experiences are not chronological (they can occur simultaneously), although they can be approached systematically. There is no fixed order or priority in which these key experiences must be encountered. Thus, this model will consider three elements as the framework for including each of these core experiences: establishing, equipping, and mobilizing.

${ }^{1}$ Pointer, 141.

${ }^{2}$ These "front door" and "side door" activities are explained in the next section. 


\section{Establishing through Nurture, Worship and Fellowship}

The process of helping members find places of belonging and service in a congregation is often labeled "assimilating" or "incorporating" believers, although incorporation seems preferable because it includes the idea of "body," which is the best image for church. ${ }^{1}$ Since phase four of this model describes only the initial elements of the incorporation process, which involves all the left wing, it uses the term "establishing."

For faith to grow, a new believer must intentionally be established through learning experiences in the church, which becomes a learning center. The focus of such teaching should be edification, not evangelism. ${ }^{2}$ Believers need to know God's word and translate this knowledge into faith by acting on what he or she knows. Besides, this basis teaching and healthy fellowship set the stage for worship, which leads to commitment and service. Aldrich affirms that "the vitality of the church is best indicated by the nature of its worship."

In addition, new believers need to enjoy fellowship with other believers to encourage them and help them to grow. Healthy believers grow because they have vital contact with the gifts of the entire body and because they are mutually committed to "one another" (Rom 12:10; 12:16;13:8; 14:13;15:5; 15:7; 15:14). Believers need to meet

\footnotetext{
'Robert L. Blast, Attracting New Members (Monrovia, CA: Church Growth Press, 1988), 136, 137.

${ }^{2}$ This "church gathered" that comes together to be built up in the faith precedes the "church scattered." However, spontaneous evangelism should be stimulated for nothing is so convincing as the witness of the newly born member of God's family.

${ }^{3}$ Aldrich, 113.
} 
together in celebration and worship, but they also need to be part of a small band where supportive fellowship can be a reality.

\section{Equipping for Stewardship}

God has given everyone a contribution to make. Each member's job in the body of Christ is to serve, just as the Jerusalem believers actively served one another, meeting physical, spiritual, and emotional needs (Acts 2:44-45). The fifth phase of this model recognizes that getting new Christians involved in giving themselves in service is important for their spiritual growth and development. Therefore, it is imperative to find out precisely what talents and spiritual gifts believers possess, and then to provide opportunities for them to develop their talents and gifts and to use them in Christ's service. It is also important to provide all believers with information and materials designed to encourage them to exercise generous stewardship on a regular basis.

\section{Mobilizing for Service}

The sixth phase defines mobilizing as a four-step process that motivates believers for action, equips them for effective service, assigns them to appropriate places of ministry according to personal desires and spiritual gifts, and supervises them, after which they are evaluated in order to improve quality and depth in the performance of service. Mobilizing turns the church into a deploying agency which get believers out of the pews and into the streets, where they can impact a hurting world for Christ. This mobilization also occurs through the structures described in the next section. 
Motivated by sound teaching, encouraged and equipped by the body, God's children lift up their eyes unto the fields ripe for harvest. The vision for service is constantly cultivated by a teaching, fellowshipping, and worshiping family. From here the cycle turns to phase one and is repeated, on and on, over and over, until Christ comes again and the church militant becomes the church triumphant.

\section{Structural Components}

NBUM churches, whatever their size, comprise a host of different personalities: extroverts and introverts, members who are highly committed and lukewarm, seekers and lifelong members. Thus, this model assumes that churches that offer people a variety of group-size choices will better accomplish the discipleship process than congregations that offer fewer options.

Peter Wagner's formula for a healthy church is used as the structure for the discipleship model for NB: Celebration + Congregation $+\mathrm{Cell}=$ Church. ${ }^{1}$ It is vitally important to understand the main function and most appropriate activities of each group. Thus a brief examination of each group follows:

\section{Celebration}

Wagner affirms that the main function of the Celebration group is to produce a special experience of worship similar to the great yearly festivals, such as the Passover,

'C. Peter Wagner, Your Church Can Grow (Glendale, CA: Regal Books, 1976), 97. 
Pentecost, Day of Atonement, and the Feast of Tabernacles. ${ }^{1}$ In his book I Believe in Church Growth, Eddie Gibbs identifies five benefits associated with this size group: ${ }^{2}$ (1) It expresses identity: a great sense of belonging is created when the people gather; (2) it provides inspiration for individual and subgroups; (3) it crystalizes intention: an occasion when people re-affirm its common identity and purpose; (4) it restores confidence: participants realize they are not alone; and (5) it establishes visibility: crowds attract attention.

Beyond that, celebration also provides a place to which Christians can bring uncommited friends with confidence that they would sense something of God's presence in the midst of his people. Celebration is a catalyst for change and growth by casting a biblical view of discipleship and mission. Among other practical applications, celebration may be used as a platform for meaningful training and mobilizing events.

\section{Congregation}

Pointer shows us that the primary function of this structure is social fellowship, which produces a sense of common identity and purpose. ${ }^{3} \mathrm{He}$ adds that the congregation also provides a sense of belonging by offering a wide range of relationships and activities

'Ibid., 98.

${ }^{2}$ Eddie Gibbs, I Believe in Church Growth (Grand Rapids, MI: Eerdmans Publishing Company, 1981), 290.

${ }^{3}$ Pointer, 128. 
that meet members" needs and interests as well as a "fellowship circle," where everyone is known by sight and usually by name.'

These groups have leaders who are skilled at meeting the particular needs of the people; for example, musical gifts, preaching and teaching gifts for the classes and subgroups. People come for systematic teaching, to sing in the choir, or to engage in training and evangelistic activities. Here, they are nurtured and motivated in their intention to grow as disciples through cognitive instruction. They also have an opportunity to discover and use their spiritual gifts. Table 12 describes the basic characteristics of the "3C" (Celebration, Congregation, and Cell) structures.

TABLE 12

THE "3C" STRATEGY

\begin{tabular}{|c|c|c|c|}
\hline Group Size & $\begin{array}{l}\text { Primary Core } \\
\text { Commitment }\end{array}$ & Disciple Making Function & Participants \\
\hline $\begin{array}{l}\text { Large: } \\
\text { Celebration }\end{array}$ & Inspiring & $\begin{array}{l}\text { Casts a biblical vision of what a Christian disciple } \\
\text { looks like. } \\
\text { Provides opportunity for commitment. } \\
\text { Reaffirms common identity. }\end{array}$ & Unlimited \\
\hline $\begin{array}{l}\text { Medium: } \\
\text { Congregation }\end{array}$ & Instructing & $\begin{array}{l}\text { Nurtures the intention to grow further as a } \\
\text { disciple of Christ through cognitive instruction. } \\
\text { Establishes a deeper understanding and practice } \\
\text { of the "one another" of biblical community. }\end{array}$ & $50-100$ \\
\hline $\begin{array}{l}\text { Small: } \\
\text { Cells }\end{array}$ & Involving & $\begin{array}{l}\text { Provides practical means by which to advance } \\
\text { discipleship growth. }\end{array}$ & $3-12$ \\
\hline
\end{tabular}

Source: Adapted from Greg Ogden, lecture course, "Growing a Disciple Making Congregation," Fuller Theological Seminary, Aug. 4-15, 2003.

'Ibid., 129. 


\section{Cell}

The cell is the primary group and basic structure that provides the church with a face-to-face context for personal and intimate relationships and lifestyle formation. ${ }^{1}$ Cells also provide the structure for support and encouragement and an environment for personal development and growth. All its essential activities have already been described in the chapter 4 (see small groups).

The Cell encompasses far more than what its name implies. Actually, the membership in NB churches accomplishes almost all its real work through cell-sized groups: church board, small Sabbath school classes, women's prayer fellowship, choir, and so on. Therefore this model recognizes the personal discipleship models of small groups, triads, one-on-one mentoring, membership and leadership classes as included in the same category, although each one has its own particular function.

Because cell groups are flexible, different groups can be organized for people at different stages of their Christian journey. Since growing to our God-given potential occurs best in the context of face-to-face relationship in a variety of discipleship communities, this model suggests: (1) Care groups, (2) Growth groups, (3) Service groups, and (4) Core groups. The entry level group (care groups) is formed on a geographical basis with the purpose of introducing new members to the experience of the Christian community by learning to practice "one another" relations.

\footnotetext{
${ }^{1}$ Pointer, 125.
} 
Table 13 shows the main characteristics of each one of the basic groups of this model, with its primary core commitment, disciple-making function, particular characteristics, and the proposed curriculum for its participants.

\section{A Manageable System}

Perhaps there is no more manageable structure for the supervision of this model than the one outlined in Exod 18 and adapted by Carl George ${ }^{1}$ (see appendix D). He suggests four types of leaders who can be identified by the number of members they serve $(X=10$; $\mathrm{L}=50 ; \mathrm{C}=100$; and $\mathrm{M}=1000$ ). Beyond what was already said in chapter 4 regarding the small group structure, most of the X's represent other nurture groups which contain an Xa (apprentice leader) and an X (leader) responsible to offer on-the-job supervision and ongoing training (train, assign, supervise).

The leader supporting 10's (cell leader) is linked for support to a leader of 50's (zone supervisors). The leader of 50's is linked to a leader of 100's (coordinator) and those of 100 's to a leader of 1000 's (district pastor). This leadership structure provides a context in which Eph 4:12 can function.

\section{Levels of the Model}

Having described the outreach, inreach, and structural elements of the model, it is now time to focus on the strategic elements that should move NB churches in the direction of disciple-making.

${ }^{1}$ Carl George, Prepare Your Church for the Future (Grand Rapids, MI: Fleming H. Revell, 1992), 123. 
TABLE 13

\section{CELL STRATEGY}

\begin{tabular}{|c|c|c|c|c|}
\hline $\begin{array}{l}\text { Group } \\
\text { Type }\end{array}$ & $\begin{array}{l}\text { Primary Core } \\
\text { Commitment }\end{array}$ & $\begin{array}{l}\text { Disciple Making Function of } \\
\text { the Group }\end{array}$ & Features & $\begin{array}{l}\text { Participant } \\
\text { Curriculum }\end{array}$ \\
\hline $\begin{array}{l}\text { Care } \\
\text { Group }\end{array}$ & Connecting & $\begin{array}{l}\text { Provides opportunity for new } \\
\text { believers to make friends with } \\
\text { other Christians and feel a } \\
\text { part of the community. } \\
\text { Identifies gifts and interests } \\
\text { as quickly as possible and } \\
\text { helps them find a role in the } \\
\text { life of the church. } \\
\text { Ensures that spiritual } \\
\text { formation is properly laid. } \\
\text { Provides learning experiences } \\
\text { about the new faith. }\end{array}$ & $\begin{array}{l}\text { Membership } \\
\text { Classes and } \\
\text { Care Groups } \\
\text { (7-12 people) }\end{array}$ & $\begin{array}{l}\text { Explore a New Life: } 8 \\
\text { lessons focusing on } \\
\text { spiritual formation } \\
\text { (Mar/Sept -Apr/Oct) } \\
\text { Explore the Disciples } \\
\text { Profile: } 8 \text { lessons } \\
\text { focusing on } \\
\text { stewardship } \\
\text { (May/Nov). } \\
\text { Explore the Church } \\
\text { Fellowship: } 6 \text { lessons } \\
\text { focusing on SDA } \\
\text { doctrines (Jun/Dec). }\end{array}$ \\
\hline $\begin{array}{l}\text { Growth } \\
\text { Group }\end{array}$ & Cultivating & $\begin{array}{l}\text { Provides an affective setting } \\
\text { for intimacy and } \\
\text { accountability. } \\
\text { Helps disciples improve their } \\
\text { attitudes, emotions, feelings, } \\
\text { and affection. } \\
\text { Provides a base for one-on- } \\
\text { one mentoring and spiritual } \\
\text { guidance (sponsor). }\end{array}$ & $\begin{array}{l}\text { Triads } \\
\text { (3-4 people) } \\
\text { One-on-one } \\
\text { mentoring } \\
\text { (2 people) }\end{array}$ & $\begin{array}{l}\text { Only personal } \\
\text { experience and Bible } \\
\text { reading }\end{array}$ \\
\hline $\begin{array}{l}\text { Service } \\
\text { Group }\end{array}$ & Collaborating & $\begin{array}{l}\text { Provides a setting for people } \\
\text { with complementary gifts } \\
\text { who are committed to a } \\
\text { common purpose and } \\
\text { performance goals. }\end{array}$ & $\begin{array}{l}\text { Mission teams } \\
\text { (3-10 people) } \\
\text { Ministry teams } \\
\text { (3-10 people) }\end{array}$ & $\begin{array}{l}\text { Explore Your } \\
\text { Personal Ministry: } 5 \\
\text { lessons focusing on } \\
\text { evangelism training } \\
\text { (Jan/Jul) } \\
\text { Explore Daily Life: } 5 \\
\text { lessons focusing on } \\
\text { topics relevant to } \\
\text { needs (Feb/Aug). }\end{array}$ \\
\hline $\begin{array}{l}\text { Core } \\
\text { Group }\end{array}$ & $\begin{array}{l}\text { Committing to } \\
\text { multiplication }\end{array}$ & $\begin{array}{l}\text { Provides training, direction, } \\
\text { and talent improvement for } \\
\text { prospective leaders. } \\
\text { Defines and discusses } \\
\text { discipleship strategies. }\end{array}$ & $\begin{array}{l}\text { Leadership } \\
\text { Class } \\
\text { (12-15 people) }\end{array}$ & $\begin{array}{l}\text { Explore a Growing } \\
\text { Church: } 6 \text { lessons. } \\
\text { Explore Leadership: } 6 \\
\text { lessons (Once a } \\
\text { month). }\end{array}$ \\
\hline
\end{tabular}

Source: Adapted from Greg Ogden, course lecture, "Growing a Disciple Making Congregation,” Fuller Theological Seminary, Aug. 4-15, 2003. 
The following levels demonstrate how to move people from prebirth to maturity. This process does not take place overnight, for it is a lifelong journey toward maturity. The term level refers to level of commitment. In the description of the levels, Engels' concepts of the discipleship process is adapted, as can be seen in figure 10 .

Engel imagines people at different points in their awareness and attitude toward Jesus Christ.' The range is from level 1 (the least amount of commitment) up to level 10 (the maximum amount of commitment) and, breaks the discipleship goals and tasks into its various phases, as is shown in figure 11 .

It would be very difficult to describe the process in terms of levels of commitment without referring to the biblical, measurable behavioral traits of an authentic disciple, as described in chapter 2 . The evidences of spiritual maturity which characterize a disciple as a committed person will be included in parentheses next to the objectives to be accomplished.

'James F. Engel and Wilbert Norton, What's Gone Wrong With the Harvest? A Communication Strategy for the Church and World Evangelism (Grand Rapids, MI: Academie Books, 1975), 45. 
HUMAN RESPONSE

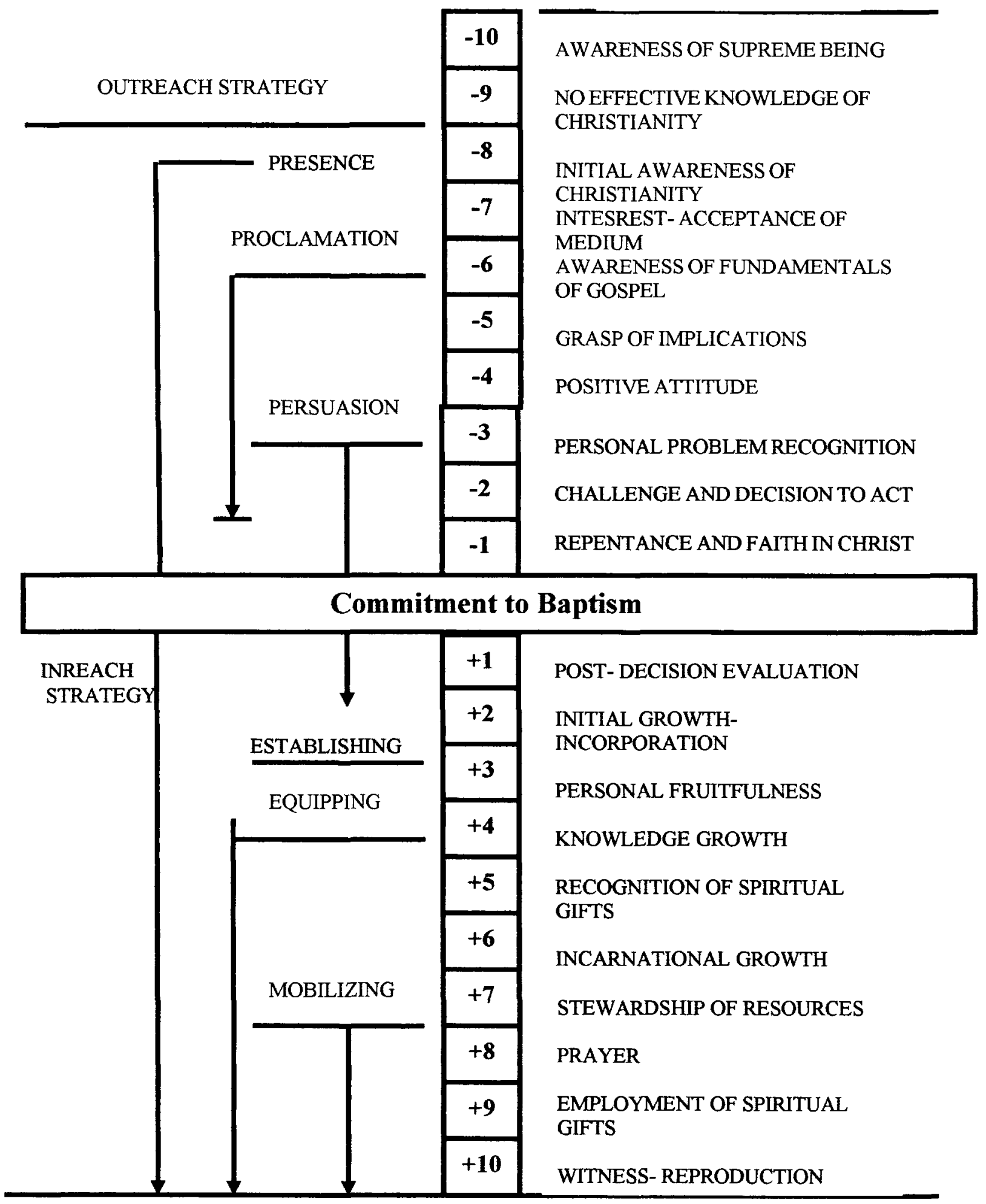

Figure 10. The Discipleship Process. Adapted from James F. Engel. What's Gone Wrong with the Harvest, 45. 


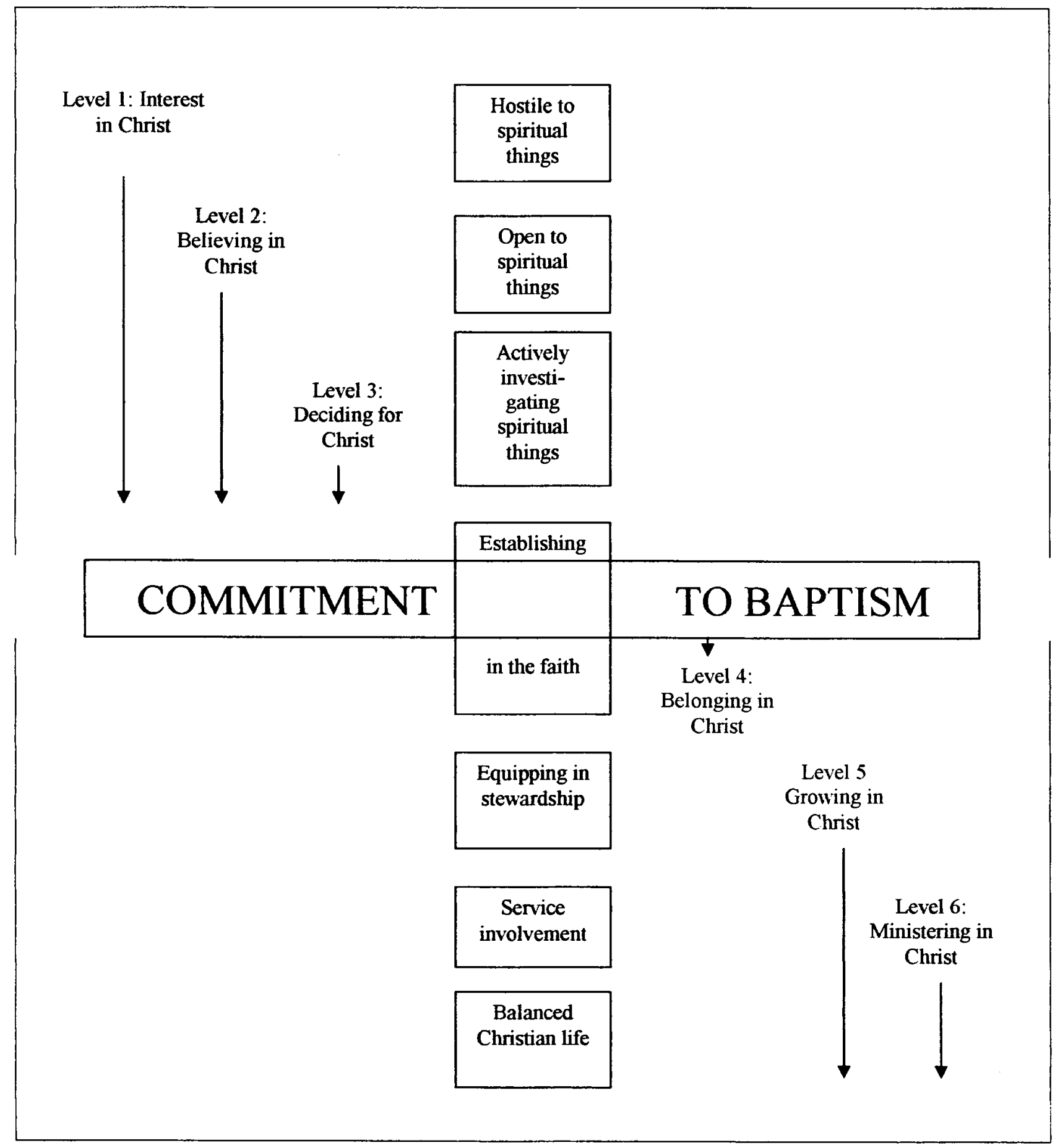

Figure 11. The Strategic Levels of the Model. 
The following traits of a true disciple are recognized: (1) A disciple has a basic, growing knowledge of the Bible and applies it to his or her life (John 8:31-32); (2) A disciple demonstrates love toward God through regular devotional time (prayer, worship, etc.) with God and the family (John 15:7-8); (3) A disciple demonstrates love toward God's people through regular attendance at church and possible membership in a small group (John 13:34-35; Heb 10:25; Acts 2:46; 5:42; 8:3); (4) A disciple has a total allegiance (putting God first) to Christ (Luke 9:23-25; 14:25-35); (5) A disciple understands his or her gifts and is involved in at least one ministry (John 15:8); (6) A disciple becomes like the Master in suffering, ministry, and purpose by multiplying himself or herself in other disciples (Matt 10:24-25; Luke 6:40). ${ }^{1}$

Each level has goals and tasks for each person's spiritual journey. An appropriate combination of methods and other influences causes them to progress in their decision process toward initial commitment and subsequent growth.

\section{Level 1: Interest in Christ}

The purpose of this level is to build contacts with unchurched people through Presence Evangelism. This cultivation level requires our presence with non-Christians because addresses emotional barriers. By focusing on the soil of the human heart, this level aims at developing trust in the messenger, for if people do not trust the messenger, they will never trust the message. ${ }^{2}$

\footnotetext{
${ }^{1}$ See chapter 2.

${ }^{2}$ Peel and Larimore, 23.
} 
The objectives in relation to this level are: (1) to gain the friendship and goodwill of the local community (especially their leaders) and meet their needs; (2) to reach unchurched Christians and invite them into the church fellowship (bridge events) and to small groups; and (3) to get as wide a hearing as possible for the gospel.

Creating interest in Christ requires the following action steps in the strategy to reach unchurched people:

1. Christian members go into a community to get acquainted with the people, win their confidence, and survey their needs. This first step follows Hesselgrave's strategy to contact people in his "Pauline Cycle" which involves:(a) courtesy contacts with formal leaders, school officials, mass media representatives, and other social segments in the community; (b) community contacts to know the people through house-to-house survey and invitation to felt-need programs; (c) selective contacts with those related to believers and prepared people (unchurched and newcomers); and (d) widespread contacts with as many people as possible through radio, advertising, and members' relationships in the work and neighborhood. ${ }^{1}$

2. The church community builds awareness and positive attitudes toward Christianity. This part is done through mass media strategy: spots on television, radio, newspaper, and news events.

3. The church regularly encourages its members to build redemptive relationships with their lost friends (workmates, neighbors, classmates, and family) according to each believer's evangelism style (Trait \#5).

'Hesselgrave, 166-167. 
4. The church members are involved in compassionate service (Kindness crusade) and social work to reach out and serve the community (Trait \#5). These good deeds are an essential foundation for the Good News (Matt 5:16) and may involve projects of hair cutting, alphabetization, cooking, English classes, prison ministry, distribution of clothes and food among the needy people in the area, and an ADRA vehicle doing medical and dental consultation to people of the community surrounding the preaching places.

5. The church utilizes the plans developed by resource departments, in various levels of the church organization, such as Sabbath School outreach, community services, health education programs, literature evangelism campaigns, and Pathfinder club.

These steps should take place in January and July.

\section{Level 2: Believing in Christ}

The purpose of this level is to build conviction on the essentials of salvation through Proclamation Evangelism. This sowing level requires thoughtful conversation or explanation of biblical truth designed to build conviction of who Jesus is, what He wants from us, and what He wants to do for us. ${ }^{1}$ Thus, the objectives involve: (a) to communicate the gospel in a clear and persuasive way to every person that can possibly be reached within the area of our responsibility; and (b) to reach the unevangelized in the target area in accordance with the following order of priority: prepared people, people related to believers, and other responsive segments of the society.

With the above in mind, the following action steps are necessary:

${ }^{1}$ Peel and Larimore, 23. 
1. Mobilize as many believers as may be available to be effectively deployed in the target area for door-to-door contacts in order to enroll as many as possible in short-term home Bible study with a family orientation (see curriculum). Church members follow up systematically to maintain contact and interest, and promote a graduation ceremony on the second night of the large group meeting for all who completed the course.

2. Conduct "side door" events for people who will not attend a "front door" large group meeting (see appendix E). Many unchurched feel that church is not for them, but they are attracted to events that specifically target them (Trait \#6). These "side door" events may be: (a) evangelistic home Bible studies, small gatherings where issues that concern these people are discussed, or (b) special short-term small groups that function as support groups (engaged couples, single parents, divorced persons, grief recovery.) and recovery groups (alcoholism, addictions, depression, etc.).

Curriculum: The Family Issues Bible Course, which focuses on five essentials of the Christian life (Bible, prayer, faith, repentance, and obedience).

These steps should take place in February and August.

\section{Level 3: Deciding for Christ}

The purpose of this level is to build commitment to baptism through Persuasion Evangelism. After someone's emotional and intellectual barriers have been broken down, the will remains. In this reaping level the evangelist graciously persuades and prays toward the goal of the person's baptism. This level requires the following objectives: (1) to secure a response to the gospel which will be genuine, lasting, and result in spiritual fruitfulness; 
(2) to help people enter into local church membership through the initiation rite of baptism; and (3) to establish visibility and impact in the community as well as provide inspiration and identity (sense of belonging) to the new believers.

Action steps for level three suggest a plethora of methods or vehicles, which include:

1. Promote a massive use of advertising and public relations through television, radio, handbills, posters, street banners, and other methods combined with the Operation Andrew which encourages members to bring their friends, workmates, and classmates.

2. Use bridge seminars that address people's needs, hopes, dreams, and expectations. The church will offer seminars on such topics as parenting skills, health, dealing with worry, finances, smoking cessation, and stress management.

3. Conduct public evangelism or large group meetings and baptismal classes (30 to 50 sequential nights) with ongoing personal evangelism and home visitation. This sevenweek evangelistic crusade will cover all essential features of Seventh-day Adventist faith and practice. The subjects will be arranged in a systematic and connected order with the subjects for the first week presented in an attractive, noncontroversial nature, and using a felt-need approach. Here is the evangelistic path of entry into baptism and church membership.

4. Promote small group gatherings to support people's decision and help them establish spiritual formation habits (prayer, Bible study, solitude, etc.). They are in the early stages of the disciple-making process and may be divided in basic small groups for 
regular people, and support groups for special people (addiction groups, divorce recovery groups, etc.)

5. Hold a large celebration event that focuses on discipleship and challenge to mission at the end of the evangelistic effort. The reaping crusade will be followed by a celebration event and continual weekend seeker service designed to supplement the evangelistic meetings on Sunday nights.

6. Encourage events to minister to people and hold them in the church, such as the choir, Pathfinders, sports events, and social events.

Curriculum: Total Living Bible series, teaching the church's 27 fundamental beliefs with emphasis on Christian lifestyle.

These steps should take place in March and September.

\section{Level 4: Belonging to Christ}

The purpose of this level is to build connections of new members in the body through nurture, worship, and fellowship. It aims at establishing new members in the faith by implanting them in an environment that encourages growth and development toward maturity.

The objectives of this level are: (1) To establish new members and to introduce them into the fellowship and discipline of a local family of believers as soon as possible; (2) to establish times and places for the assembling of believers, making these meetings as spiritually meaningful and inspiring as possible; and (3) to help believers in their spontaneous witness while growing in small group settings. Opportunity will be afforded 
to participate in ministry so that the new member feels included and can make a meaningful contribution to the church program.

To accomplish these objectives, the following action steps are suggested:

1. The new member will be encouraged to join the congregation's midweek service, which focuses on worship and prayer, and a Sabbath morning corporate worship designed to mature the believer by focusing on worship, in-depth Bible study, and prayer (Trait \#3). Here a homiletical calendar oriented to discipleship is expected to be designed in such a way as to systematically place all essential beliefs and spiritual formation practices into a thirty-two-week schedule. Then the Sunday night seeker service will be a place to bring unchurched friends and strengthen faith through a repetition of the same subjects of the evangelistic crusade.

2. The pastor and church board will assign some mature member to sponsor (Barnabas Operation: one-on-one mentoring) each new member. The one selected should be capable of providing support and be of spiritual strength to the new believer. Here is where age, interests, and many other things will be taken into consideration. There is no curriculum in this group but only assigned tasks, which will be coordinated and supervised by a regional discipleship director.

3. Encouragement will be provided to new members so they can be involved in regular and special small groups (see Action step 4 of level 3). While participating in the large gatherings and even before making a commitment to Christ and to the church, the new member will be involved in a face-to-face context for personal care, intimate relationship, and lifestyle formation through Explore lessons (Traits \#1, 2). 
4. The new members will practice their growing faith by reaching out to others outside the group on a two-by-two basis (the partner may or may not be the sponsor). The triad starts when they begin to disciple a third person through visitation and Bible study.

5. The new members will receive a meaningful reception experience (banquet, interview, presentation by the sponsor, pictures, etc.), and be involved in social activities to help them substitute former friends and amusements.

6. Follow-up methods will be used to establish and hold converts. These will include a second series of meetings on weekends to repeat and fix the doctrinal points, membership class on Sabbath to instruct new members in the principles of salvation, and a visitation program which includes the evangelist, elders, deacons, and small group leaders, among others.

7. Continued relationship between the evangelist and the church will be stressed to stimulate spirituality and maturity.

Curriculum: Explore a New Life focusing on spiritual formation: (a) study and meditation; (b) prayer and listening; (c) simplicity and fasting; (d) solitude and silence; (e) service.

These steps should take place in April and October.

\section{Level 5: Growing in Christ}

The purpose of this level is to build cultivation of a balanced Christian life through stewardship practice. Helping new Christians become faithful stewards of their time, health, talents, and possessions is important to their spiritual growth and development. 
The term steward refers to a manager, a supervisor, or an administrator. George E. Brazee defines stewardship as the "sum total of our attitude, and reaction toward the divine Creator and His creation."

The basic objectives of this level are: (1) To encourage believers to practice faithful stewardship of time, talents, treasure, and temple (body) that God has given them; (2) to select men and women who are gifted and spiritually qualified for leadership in the local church and organize the church in a functional, effective, and expandable way; and (3) to motivate believers in their spontaneous witness and church ministries while learning in small group settings.

Some necessary action steps in dealing with these objectives will be:

1. Use Sabbath worship, membership classes, and nurture groups to reinforce the biblical principles of stewardship (Trait \#4).

Curriculum: Explore the Disciple's Profile: (a) profile of a disciple, (b) the disciple's lifestyle, (c) the disciple's time, (d) the disciple's home and recreation, (e) the disciple's possessions, (f) the disciple's worship and fellowship, and (g) the disciple and the Kingdom.

2. Promote a two-week seminar (Wednesday/Friday to Sunday) conducted by a trained local leader or an invited specialist to equip new believers in the essentials of church fellowship. If people are to belong they need to know and identify with the history, traditions, philosophy, and goals of the congregation.

${ }^{1}$ George E. Brazee, Dynamic Stewardship Strategies: Harnessing Time, Talent and Treasury for Church Growth (Grand Rapids, MI: Baker Book House, 1989), 12. 
Curriculum: Explore the Church Fellowship: (a) The Christian and Fellowship; (b) Our History and the Fellowship; (c) The Church Fellowship and Prophecy; (d) Ceremonies of Fellowship; (e) Health Teachings within the Fellowship; and (f) The Finances of Fellowship.

3. Special responsibilities and training are provided to those who are recognized as leaders and potential leaders. Job descriptions are written and ready for use.

These steps should take place in May and November.

\section{Level 6: Ministering in Christ}

The purpose of this level is to build collaborative action through equipping and mobilization. Too often, the process of discipleship stops at this point. Ministering is the action by which new Christians seek to reproduce their faith in the lives of others. This lay mobilization primarily involves helping people to discover their gifts, motivation, and ministry placement so that they become Christ's servants. Their ministry may take place within the church and in the local community with activities such as an inner-city mission or a church planting team.

The objectives of this level are: (1) to equip believers in the great avenues of personal ministry; and (2) to mobilize the majority of believers for active ministry.

Four important action steps involve people through equipping and mobilization:

1. People will continue in their discipleship small group. 
2. Classes in evangelism are provided so that people can understand the importance of evangelism, and discover their style of evangelism and how to share their faith with the lost.

Curriculum: Existing members of the church will be equipped with Connect and Making Friends for God Evangelism Courses covering areas such as spiritual gifts, visitation, mentoring new members, giving Bible studies, and small group techniques, while new members will use Explore Your Personal Ministry focusing on (a) the call to ministry; (b) the spirit of ministry; (c) the ministering gifts; (d) the minister and community; (e) the methods of ministering; and (f) the rewards of ministry.

3. Small groups will be the basis for assessing peoples' gifts and matching these gifts with the church ministries for which they are best suited.

4. They will be immediately assigned to a supervised area to work according to a strategic plan. Thus, this last point becomes, chronologically speaking, level one.

These steps should take place in June and December.

\section{Level 7: Leading in Christ}

The purpose of this level is to build a Core Leadership among new believers. At this level, a ministry-leadership core is established from which it is possible to create, direct, and expand the church's ministry through evangelism and church planting. This core group is also important for providing a setting to train leaders who are expected to reproduce, multiply, and help the church with a great team of leaders. 
Thus, the main objective is to enlist disciples to become disciple makers. These leaders will become small group leaders, elders, church planters, and church officers (Trait \#6). Not everyone who is a disciple will move to level 7. This is for a select group who are key to the ministry. The staff and small group leaders in particular look for these gifted leaders and individually invite them to consider moving on to level 7 . The pastor and others will pour much of their time and lives into these potential leaders.

Four action steps to start and run a leadership community are indicated:

1. The prospective leaders must meet certain requirements for leadership (1 Tim 3; Titus 2), depending on their anticipated ministry (small group, church department, church planter, etc.).

2. The prospective leader will begin as an apprentice leader, assisting a small group leader or a church department. No one simply walks in and becomes a leader overnight.

3. The apprentice leader will develop leadership skills working within the small group three weeks a month and will gain leadership knowledge attending a training seminar (character, knowledge, skills training session) meeting once a month.

4. The apprentice leaders will be mentored on a on-on-one basis by someone on the church staff (elders or department leaders), depending on their future ministry goals.

Curriculum: Explore a Growing Church: (a) why church growth? (the mission of the SDA church); (b) the four dimensions of growth; (c) signs of growth; (d) organizing for growth; (e) planning for growth; (f) leading for growth.

These steps should take place once a month from January to December. 
The organizing modes that will capture the strategy and translate it into action also lay out the pattern for how people will progress through discipleship faith toward maturity. The process and the purposes of each level related to covenantal commitments to advance in discipleship growth are shown in table 14.

TABLE 14

\section{DISCIPLESHIP LEVELS}

\begin{tabular}{|c|c|c|c|}
\hline Levels & $\begin{array}{l}\text { Developmental } \\
\text { Stage } \\
\end{array}$ & Covenantal Decision & Appropriate Group \\
\hline 1 and 2 & $\begin{array}{l}\text { From Marginal to } \\
\text { Minded }\end{array}$ & $\begin{array}{l}\text { Examines spiritual truth } \\
\text { carefully }\end{array}$ & $\begin{array}{l}\text { Cell } \\
\text { Service groups and mission teams } \\
\text { One on One }\end{array}$ \\
\hline 3 & $\begin{array}{l}\text { Moved to } \\
\text { Commitment }\end{array}$ & $\begin{array}{l}\text { Commitment to Christ } \\
\text { Commitment to Church }\end{array}$ & $\begin{array}{l}\text { Celebration (front door) } \\
\text { Evangelistic meetings in the } \\
\text { congregation or in an auditorium } \\
\text { (unlimited) } \\
\text { Large Group event celebrating } \\
\text { victory. (Unlimited) } \\
\text { Cell (side door) } \\
\text { One-on-One } \\
\text { Mission teams }\end{array}$ \\
\hline 4 & Membership & $\begin{array}{l}\text { Commitment to } \\
\text { apprenticeship and personal } \\
\text { growth }\end{array}$ & $\begin{array}{l}\text { Congregation ( } 30-100) \\
\text { Casting a biblical vision of a } \\
\text { disciple; family discipleship; re- } \\
\text { affirming identity, etc. }\end{array}$ \\
\hline 5 & $\begin{array}{l}\text { Managing Christian } \\
\text { Life }\end{array}$ & Commitment to stewardship & $\begin{array}{l}\text { Cell: } \\
\text { Care group (6-12); } \\
\text { Triad (2-3); } \\
\text { One-on-One Mentor (2) }\end{array}$ \\
\hline 6 & Mission & $\begin{array}{l}\text { Commitment to Kingdom } \\
\text { growth }\end{array}$ & $\begin{array}{l}\text { Ministry teams (church ) and } \\
\text { Mission teams (community). }\end{array}$ \\
\hline 7 & Mature Leadership & $\begin{array}{l}\text { Commitment to } \\
\text { multiplication }\end{array}$ & Special class $(10-30)$ \\
\hline
\end{tabular}




\section{Model Implementation and Evaluation}

The purpose of this brief section is to put the necessary action in the context of a overall planning and evaluating. The strategy previously discussed in the levels are included here. This model for reaching and discipling people should be put into action in a target area, and its outcome should be assessed carefully to see if the stated mission, objectives, goals, and activities are met effectively. The overall program of evangelism developed by the NBC is coordinated by the NBUM board which is responsible for selecting a specific field setting (Conference or Mission) capable of being a functioning ministry lab for seminarians. ${ }^{1}$ It also provides personnel and financial resources necessary to accomplish church planting and discipleship in its territory.

After the plan is voted by the NBUM board, organizational and procedural details must be worked out in accordance with the governing rules of the local mission or conference involved. Some of their most important functions should be to encourage an overall plan for church extension, to suggest ways and means of carrying out the plan, and to provide leadership in implementation.

The next requirement is a basic organization that will provide for direction and cooperation in a plan to extend the frontiers of the church of Christ. With the foregoing in mind, a suggested framework for implementing the discipleship model for evangelism in NBUM may be divided to six periods: ${ }^{2}$ (1) planning period, (2) preparatory period, (3)

${ }^{1}$ Criteria for selecting such a field setting are described in chapter 5 .

${ }^{2} \mathrm{~A}$ tentative approach to achieve this planning through a PERT (Program Evaluation and Review Technique) system is described in appendix L. These periods are adapted from Samuel D. Faircloth's book Church Planting for Reproduction (Grand Rapids, MI: Baker Book House, 
outreach period, (4) inreach period, (5) growth and organization period, and (6) multiplication period.

\section{Planning Period}

The events and activities of this period conclude with a final plan. Planning should be the result of united prayer and corporate consultation. Before NBC and local leadership of the conference or mission can get on with the task of drawing up a plan and presenting it to the church, we must decide on timing and definite areas that will become the target of our immediate attention and labors.

The place for church planting should be chosen by local field administrators considering geographic and demographic factors as well as the presence of prospects and the presence of a nucleus of believers. ${ }^{1}$ Beyond that, a detailed survey including such things as the demographics, religious data, and socio-economic factors of the community is important to reveal the most responsive areas and to define the community profile (basic needs, religion characteristics.). ${ }^{2}$

Once all demographic information has been gathered and evaluated, the next step in the initial evangelistic planning for the target area is to review discipleship principles and to share the survey discoveries with the conference or mission staff and with the lay leaders of the churches close to the target area. This task is performed by the NBC teacher and the field Church Ministry director who coordinate the effort. The objective of this

${ }^{1}$ Roger McNamara, A Practical Guide to Church Planting (Cleveland, OH: Baptist MidMission, 1983), 37-51.

${ }^{2}$ Ibid. 
meeting is to challenge them, to involve them in the elaboration of a plan with clear goals, activities, and timetable as well as to define their roles in the overall strategy which involves seminarians and churches.

\section{Preparatory Period}

While determining where God wants NBC to plant churches, there are some important preparations to make. First of all, there is a need to promote a caring atmosphere among the churches involved in the program by focusing on the SDA mission philosophy and the missionary nature of the SDA Church, by combating local church diseases, ${ }^{1}$ by presenting local church leaders the strategy to plant churches and to make disciples, and by cultivating a loving climate in the church. ${ }^{2}$

The next step is to promote an atmosphere of commitment in the church in terms of prayer, training, money, and people. Pragmatically, discipling people and church planting demand clear and concrete involvement of a potential sponsoring congregation. It is good stewardship as well as good planning to determine what a task will cost in terms of money and to assess available resources. Perhaps a plan for raising extra funds would increase the budget to meet the goals and needs of the program. ${ }^{3}$

\section{0.}

${ }^{1}$ C. Peter Wagner, Your Church Can Be Healthy (Nashville, TN: Abingdon, 1979), 12-

${ }^{2}$ Win Arn, Carroll Nyquist, and Charles Arn, Who Cares about Love? (Monrovia, CA: Church Growth Press, 1986), 8-192.

${ }^{3}$ Chester L. Tolston, Proven Principles for Finding Funds (Grand Rapids, MI: Baker Books, 2003), 55-77. 
A number of matters should be attended to before moving to the selected city. These include the preparation of resources and printed materials (Bibles, equipment, Bible lessons, Power Point presentations, etc.), as well as the survey of the target areas, looking for the possibility to buy, build, or rent appropriate facilities. There is also a need to secure a suitable meeting place, together with a legal contract for its use.

During this preparatory period education in mission and evangelism take place.

First, the seminarians are involved in phases one and two of their discipleship model at NB C. ${ }^{1}$ Second, training and enriching of lay leaders is provided by conference staff and NBC teachers so they can be the equippers and the agents to mobilize the entire church for growth. As a result of the understanding gained from these training sections, the church will be organized for evangelistic outreach in the community and prepared to receive the converts into appropriate structures and programs.

\section{Outreach Period}

The events and activities of this period lead to the first converts. By this time, if the previous actions have been undertaken, the Holy Spirit has generated enthusiasm and expectancy in the congregations and in the team members. Nevertheless, it is imperative to promote spiritual preparation in order to develop a passion for lost people. This can be done through emphasis on the central place of the Holy Spirit in the mission of the church, by providing opportunities for periodic renewal, and by spiritual motivation. ${ }^{2}$

\footnotetext{
${ }^{1}$ See the discipleship model for seminary students in chapter 4.

${ }^{2}$ Charles L. Chaney, Church Planting at the End of the Twentieth Century (Wheaton, IL: Tyndale House Publishers, 1982), 80-92.
} 
During this period, mobilization of the believers in an intentional effort to establish preevangelistic contacts is necessary. This mobilization will move people to level one of their spiritual journey (Interest in Christ) through the action steps delineated earlier in this chapter. Then, the heart of the task of the outreach period must be the effective communication of the gospel and soul winning in the target area by using the methods and activities also described in levels two (Believing in Christ) and three (Deciding for Christ).

\section{Inreach Period}

The events and activities of this period terminate with the organization of new churches. Perhaps one of the exciting moments in the implementation of the discipleship model comes when new believers are introduced to one another and begin to meet together establishing close connections (Level 4: Belonging in Christ). The key here is to help them become part of a group (choir, small group, Pathfinders, etc.) before formally uniting with the church through baptism. ${ }^{1}$

Two more things needed by new believers immediately following their conversion are clear instruction as to what God expects of His family members and caring Christian friendship. New believers should receive the deeper teachings of the faith (indoctrination) and be introduced to mature believers who will act as counselors and friends while they are established in the faith. Besides, it is well to provide for various groups of believers in the emerging church (care groups, growth groups, service groups).

\section{9.}

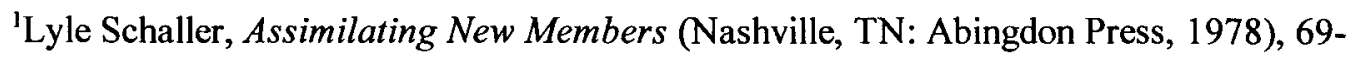


New members should also be encouraged to accept a formal role or office which gives a sense of belonging and causes identification with the congregation. ${ }^{1}$ At the same time, it is also crucial to organize the new local church.

\section{Period of Growth and Organization}

In this period, three major subgoals are developed toward the final goal of establishing a mature church, capable and motivated to reproduce. The events and activities should aim for (1) a church conscious of its identity, (2) a church that takes care of itself, and a (3) a church that exists for others.

First, to help them grasp the feeling that they are special, unique, not like anyone else, new believers should be introduced to a carefully-thought-out program of instruction by repeating the same biblical doctrines learned during the outreach period. At the same time they should be taught, the basics of spiritual formation. Involved in the nurture groups of the model (care groups and membership classes), they continue a significant program of instruction through specific Christian literature and classes emphasizing aspects of SDA history and prophecies.

Second, in order to accomplish the goal of helping the church take care of itself, new believers should be conscious of their stewardship responsibilities by carefully being re-instructed in the biblical doctrine of stewardship. They should be reminded of the

'Joel D. Heck, New Members Assimilation: Practical Prevention of Backdoor Loss through Frontdoor Care (St. Louis, MO: Concordia Publishing House, 1984), 33. 
financial goals of the church and be provided with information and materials designed to encourage them to exercise generous stewardship on a regular basis.

Because stewardship has to do with all that a Christian possesses-time, talents, temple (body), and treasure-teaching new believers to practice a biblical lifestyle in the management of time, health principles, and practical aspects of the life such as recreation, Christian home, and personal appearance should also be emphasized.

The new church must assume its financial independence, but it must also grow in an orderly, administrative way. Therefore, an important task at this point is to select and equip leaders for administrative functions, to provide a job description for each needed task of the church, and to make certain that leaders are assigned and understand their job.

Assuming that the practice of Christian worship constitutes part of the administrative function of the church, the student evangelists should help new leaders improve communication in the public worship services by providing them with training and sermons for at least six months. Observance of the Lord's Supper and orientation toward balanced and attractive services should also be included. ${ }^{1}$

Third, to develop a new church that lives for others, two subjects are central: evangelism and social concern. If new Christians are to penetrate the community with their witness, they must know how to share Christ with others. Therefore, the first goal should be instruct every person in the church to do personal evangelism whenever and wherever possible. Next, it is necessary to find out precisely what talents and spiritual gifts for

${ }^{1}$ Hesselgrave, 346. 
Christian service the believers possess, and then to provide opportunities for them to develop their talents and spiritual gifts and to use them in an aggressive evangelism. ${ }^{1}$

In order to effectively make contact with the people on different levels in the target area, social concern seems to be a bridge of love that allows church members to deal with the people's physical as well as spiritual needs. Therefore the first step is to involve new Christians in a carefully planned area survey in an honest attempt to gather information to be used in ministry to the community. ${ }^{2}$

\section{Period of Reproduction and Evaluation}

The period of reproduction should result when the goals of the previous periods are more or less achieved. By this time, when plans for withdrawal of the student evangelists from the new churches are taking place, important aspects have to be considered such as local church preparation for their departure, leadership transition, and the continuation of ministries of the new church under a continued mentor relationship with the student evangelist, churches in the areas, and the denomination. ${ }^{3}$

During this period of reproduction, teams of new Christians will be prepared to be sent out to aid in pioneer work in a new target area. Repeating the same strategic planning of this model, they will be deployed in home visitations, Bible study groups, and special reaping crusades (10 days) with the student evangelists as guest speakers.

'Ibid.

${ }^{2}$ Ibid., 191.

${ }^{3}$ Ibid., 383-421. 
This event will take place six months after the departure of the students. The purpose of their return is for follow-up work and post-baptismal activities, as well as to preach every night for more decisions, both of new converts and those who were undecided from the last crusade. It will be a busy time, visiting the homes of converts, the members who have apostatized, and also to take time with the local leaders to discuss matters dealing with the future of the church.

Despite all these activities, pastors will be instructed to take a survey among newly baptized members and also the lost members, to measure the quantitative and qualitative factors of their growth or their spiritual death. Besides that, two more levels of evaluation will be focused on here. There is a need to evaluate the participation of the students and have them evaluate the coach-teacher, to help each student reach her or his full potential. As well, the program (activities, goals, resources, etc.) should be evaluated. ${ }^{1}$ All the information gathered will be processed at the Evangelism Institute of the NBC for an analysis of past progress and used to correct the discipleship process for the following years.

With the presentation of the intended plan, the dissertation is complete. Chapter 7 summarizes the work and makes recommendations.

'Bobb Biehl, Master Planning: The Complete Guide for Building a Strategic Plan for Your Business, Church, or Organization (Nashville: Broadman and Holman Publishers, 1997), 138. 


\section{CHAPTER VII}

\section{CONCLUSIONS AND RECOMMENDATIONS}

Discipleship involves a lifelong apprenticeship, a commitment to lifelong learning, development and growth. Discipleship is not simply a book or set of tapes that one goes through to reach maturity. The process certainly includes a curriculum; however, discipleship is much more process oriented. Although in some books the word discipleship is attached to the training, and people in the church gain the impression that this one area is primarily what discipleship is all about, this dissertation suggests that discipleship involves all ministries of the church. Wilkins put it in these words:

"Discipleship is the Christian life and the church needs to address itself to all areas in the process of Christian life."1 Barna summarizes it in just a few words: "Discipleship is an artful blend of what we know and what we do."2

The objective of this study was to discover the effectiveness of making disciples through public evangelism and church planting by seminarians of the NBC, and to learn with certainty the current symptoms of the discipleship deficiency and the current factors that have contributed to this condition. From the analysis and evaluation of these surveys,

${ }^{1}$ Wilkins, 346.

${ }^{2}$ Barna, 31. 
it appears that student evangelistic campaigns were very effective in attracting new converts to the churches but somewhat counter-productive in the second part of discipling them through nurture, equipping, and involving them in church work. The study has shown that the probable causes that have contributed to this condition included an improper disciple-making understanding, which originated in improper focus on pastoral equipping, thus failing to provide supervision and leadership to the discipleship process. In addition there was a lack of a discipleship strategy with a clear and easy path, onto which people can get if they want to become mature and reproducing disciples. Finally, there were imbalanced and incomplete models of discipleship.

Based on the analysis of the churches in NBUM territory and the research of biblical models of discipleship, as well as of current literature related to this issue, discipleship happens when:

1. The church's view of discipleship is inseparable from conversion,

2. The church creates a clear corporate pathway to maturity,

3. The church balances individuality and community through different types of settings and different methodologies, such as one-on-one mentoring, small groups, and family,

4. The church views discipleship as incorporating all spheres of our life (personal holiness, family, work, service, finances, etc.),

5. The church recognizes that transformation occurs in the confluence of relational transparency, biblical truth, and accountability,

6. The discipleship process results in reproduction or multiplication. 


\section{Recommendations}

Several specific recommendations follow for district pastors, local elders, and field administrators as they join together to fulfill the gospel commission as given by Jesus Christ. In addition, recommendations for further study are made.

To the District Pastors and Elders

1. Since the pastors are acknowledged as the catalyst behind the commitment to spiritual growth, they should recognize that disciple-making is a process that will not occur without their leadership. Therefore, it is highly recommended that their focus be streamlined to prioritize and support discipleship. That includes establishing a simple but intelligent strategy that ties all ministry programs to discipleship and eliminates programs that divert people's attention and the church's resources.

2. There is a need for district pastors and evangelists to take more seriously Ellen G. White's counsels in her book Evangelism regarding establishing and holding new converts.' They should teach people in a systematic rather than random way. They must give special attention to the frequently neglected "branches of the work-health reform, spiritual gifts, systematic benevolence, and the great branches of the missionary work"; and "not be at all satisfied with their success but should be developing serviceable Christians as well."

${ }^{1}$ White, Evangelism, 334-345.

${ }^{2}$ Ibid., 343.

${ }^{3}$ Ibid., 345. 
3. Related to the above recommendations is the need to emphasize a balanced combination of teaching and training. Pastors should teach ideas and concepts, but also train through the transmission of learned skills (apprenticeship). ${ }^{1}$ The church should become an equipping center where the people of God can be trained. If discipleship training is to be carried out in the church with any degree of effectiveness, it is obvious the church will need to provide an environment where training can take place.

\section{To Administrative Leaders}

1. Efforts should be made to calibrate standards to measure pastoral ministry, which should be considered successful not only in terms of finding new converts through evangelism, but also have measurable goals in terms of enfolding people into the SDA Church, providing them with proper training, and fielding them into ministry and disciplemaking. Therefore, in order for the ministry of discipleship to secure a foundation in the Seventh-day Adventist churches in NB, a large number of pastors who share the same vision concerning discipleship is needed. One effective way to encourage and assist pastors is to provide a "Discipleship Seminar," and to include an educational-formational model of discipleship in the curriculum of the seminaries.

2. Looking at the challenges of operating a discipleship process in a specific target area, it is recommended that balanced resources be allocated to specific evangelistic projects. Establishing and equipping new converts are on the same continuum, just as is giving birth through evangelism. Since church growth and discipleship are a holistic

\footnotetext{
${ }^{1}$ Hanks, 93-97.
} 
endeavor, a balanced distribution of efforts and resources needs to be met.

3. More consideration must be given to different methods and approaches of effective discipleship. Making disciples in this age requires the church to take seriously each person's culture, background, educational level, interest in spirituality, and level of Christian growth. The church can no longer treat everyone the same or offer the same resource materials, the same learning opportunity, or discipling structure. People have varying needs, styles of learning, and time availability.

\section{For Further Study}

Since this research has been tailored made for NBUM territory, to implement it in other fields will need to contextualize to the needs of that particular region. A comprehensive field survey will enable field leaders, pastors, and local elders to measure the qualitative and quantitative factors that are affecting the mission to make disciples.

Finally, of great importance is the need to implement the suggested model and recommendations made in this research. Implementing the model, therefore, occupies an important place in this research project. Any church growth information without a deliberate attempt to implement its findings is of little or no value to the growth of any movement. 
APPENDIX A

THE GREAT COMMISSION 
Appendix A

The Great Commission

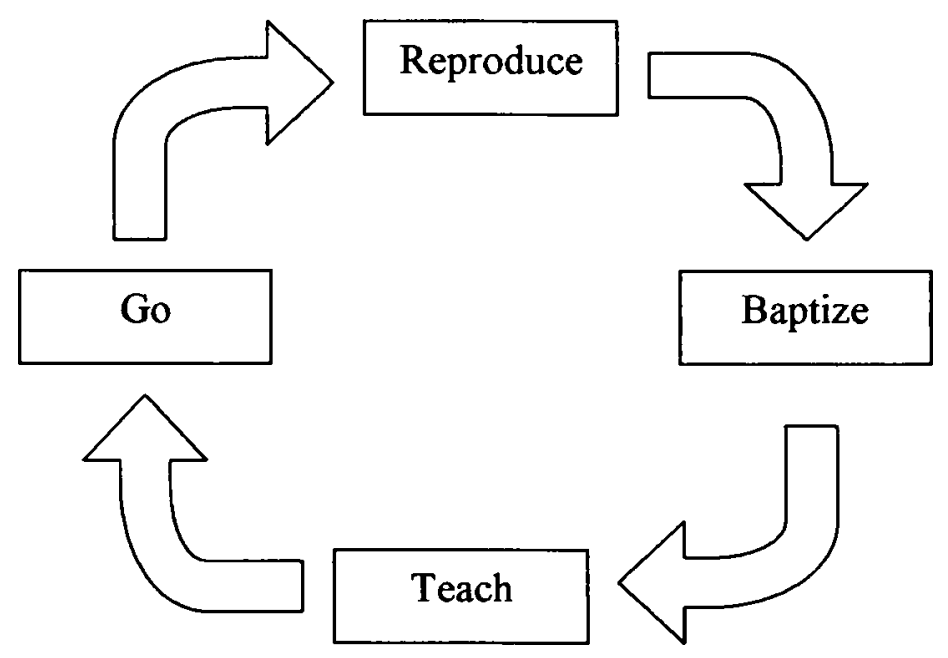

\section{Step 1: Go (or move out)}

Discipled people are involved in service through:

1. Spontaneous evangelism: "networks"or relationships (John 1:40-45; Mark 5:19; Acts 10:24)

2. Systematic evangelism: planned missions, events (Luke 9:1-6; Acts 8:5-8; 1:8)

3. Compassionate service in the community: (Matt 9:36; 25:31-36; Luke 4:16-19)

\section{Step 2: Reproduce}

Discipled people reproduce themselves (John 15:1-11) through:

1. Personal relationships and long-term commitment to people (Luke 9:4,5;10:5-11)

2. Elementary Instruction. Prospective people require basic instruction in the fundamentals of the faith (Acts $2: 14,41 ; 8: 30-40 ; \mathrm{Heb} 6: 1-3$ ). It's necessary to teach them in what Jesus meant to be a disciple:

a) Challenging them to count the cost. For some this meant riches (Matt 19:16-26), for others it meant attachment to family (Matt 8:21-22; Luke 14:25-27).

b) Helping them to keep the basic teachings of Jesus (John 8:31, 32).

c) Demonstrating and teaching them to love one another (John 13:34, 35).

d) Teaching them the importance of bearing fruits (John 15:8) which are the fruits of the Spirit (Gal 5:22-27), good works (Phil 1:11; Col 1:10), and new converts (John 4:3-38).

3. Calling them to commitment (Mark 1:14-20; Acts 2:38-42; 17:29-31). 


\section{Step 3: Baptize}

The baptism is the initiation rite which marks the entry into the local community and the people of God (Matt 28:19; Mark 16:16; Rom 6:4). Baptism and confession of faith are done in three ways:

1. Verbal confession (Rom 10:9-11,13)

2. Symbolic confession by water baptism (Rom 6:4).

3. By a changed life (Acts 26:20; James 2:18) and good works.

\section{Step 4 : Teach}

Using different types of settings like one-on-one relationships (Barnabas/Paul), mentor relationships (Jesus/disciples), or small groups (Early Church), the growth of disciples includes:

1. Nurturing and strengthen new believers (1 Thess. 4:1; Col 1:9,10; Acts 14:21,22).

2. Providing an atmosphere of loving fellowship (John 13:35).

3. Equipping for ministry (Eph 4:11-13) through discovery and utilization of spiritual gifts (Rom 12; 1 Cor 12). On-the-job training must add to the intensive training.

4. Assimilating through involvement in service. 
APPENDIX B

THE PURPOSE-DRIVEN MODEL 
Appendix B

The Purpose Driven Model

\section{The Life Development Process}
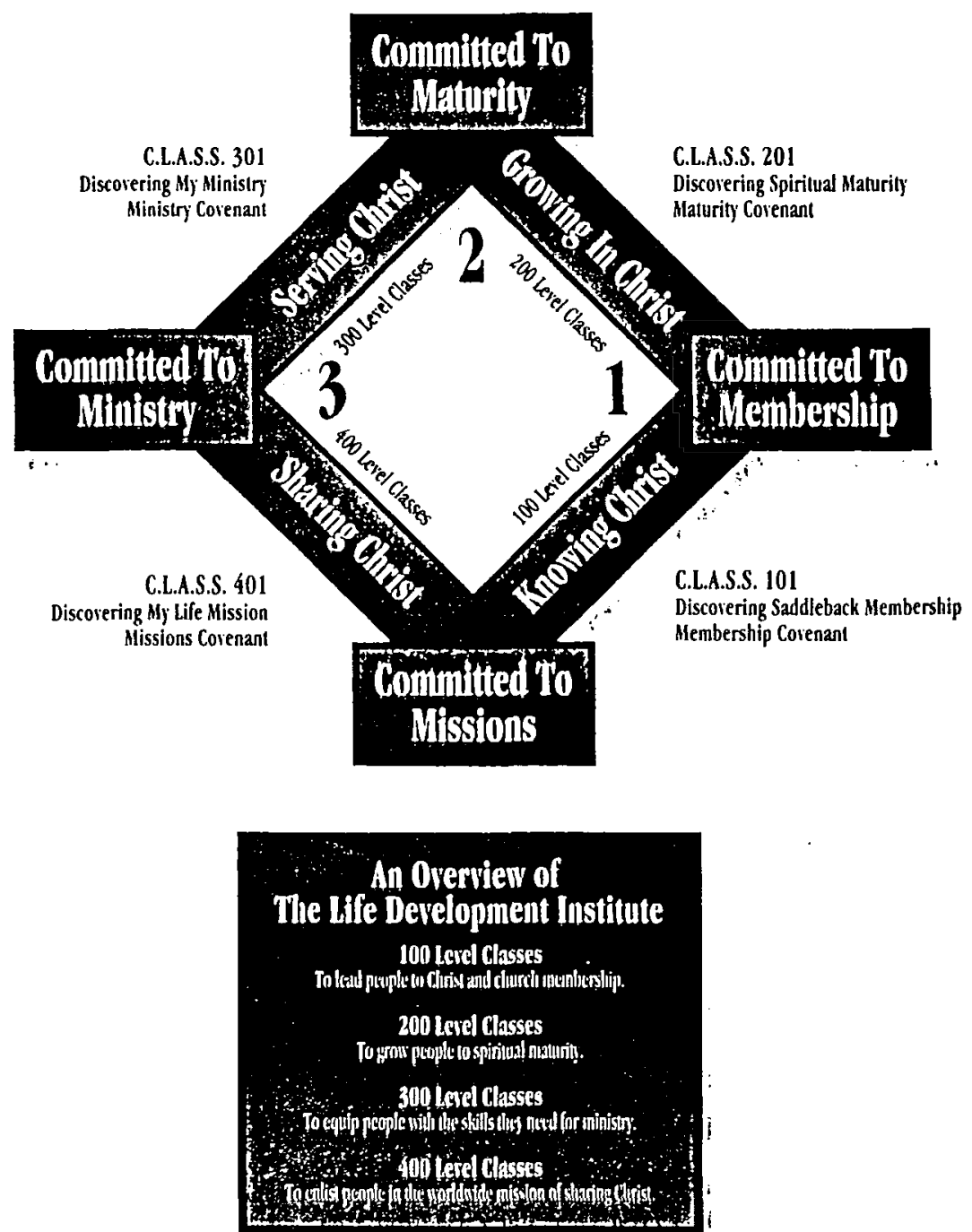

Source: Rick Warren, The Purpose Driven Church: Church Growth Without Compromising Your Message and Mission, 99. 


\section{APPENDIX C}

THE CONNECTING MODEL 


\section{Appendix C}

\section{The Connecting Model}

\section{INTENTIONAL AsSimilation Strategy}
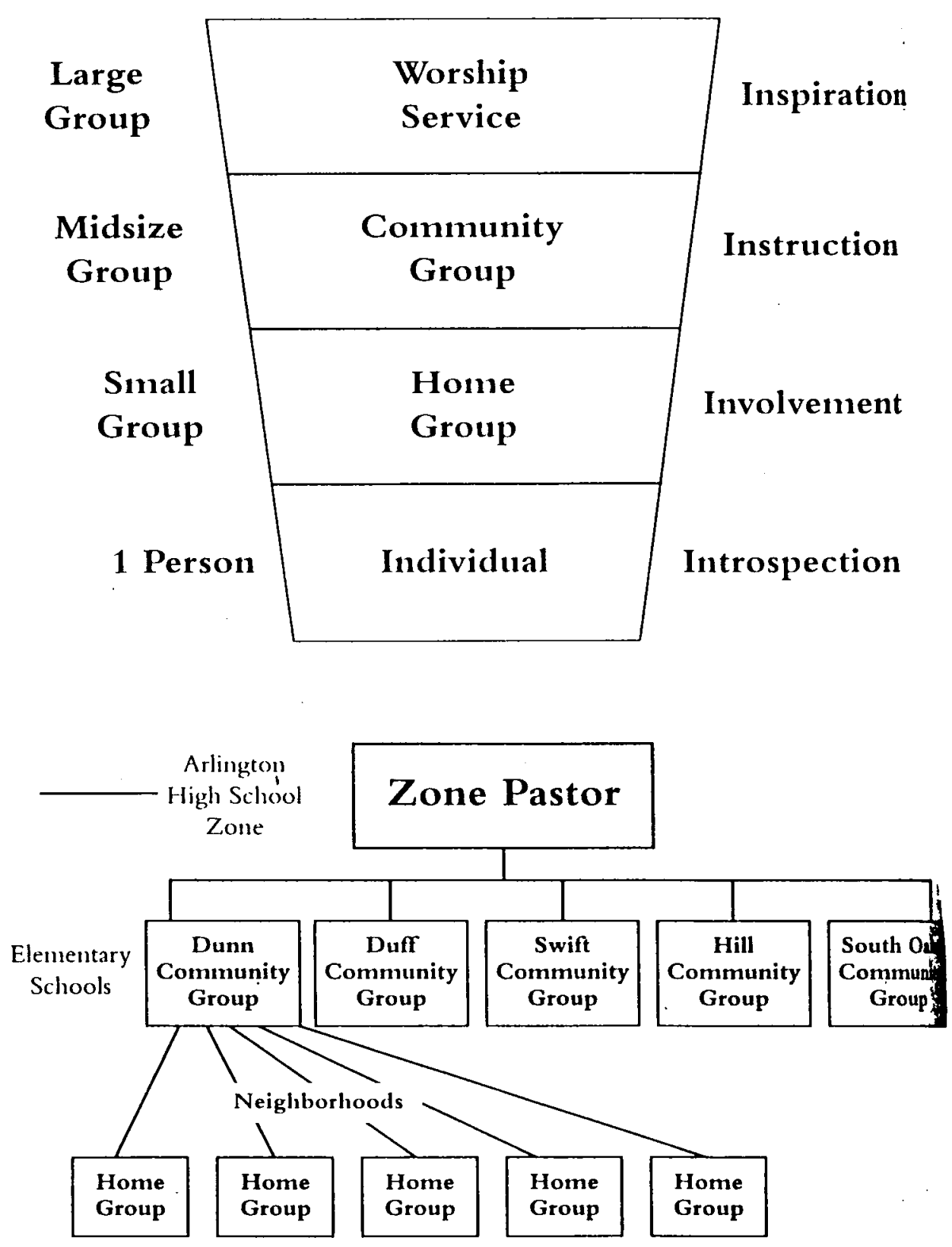

Source: Randy Frazee, The Connecting Church: Beyond Small Groups to Authentic Community, 89. 


\section{APPENDIX D}

THE MANAGEABLE SYSTEM 


\section{Appendix D}

The Manageable System
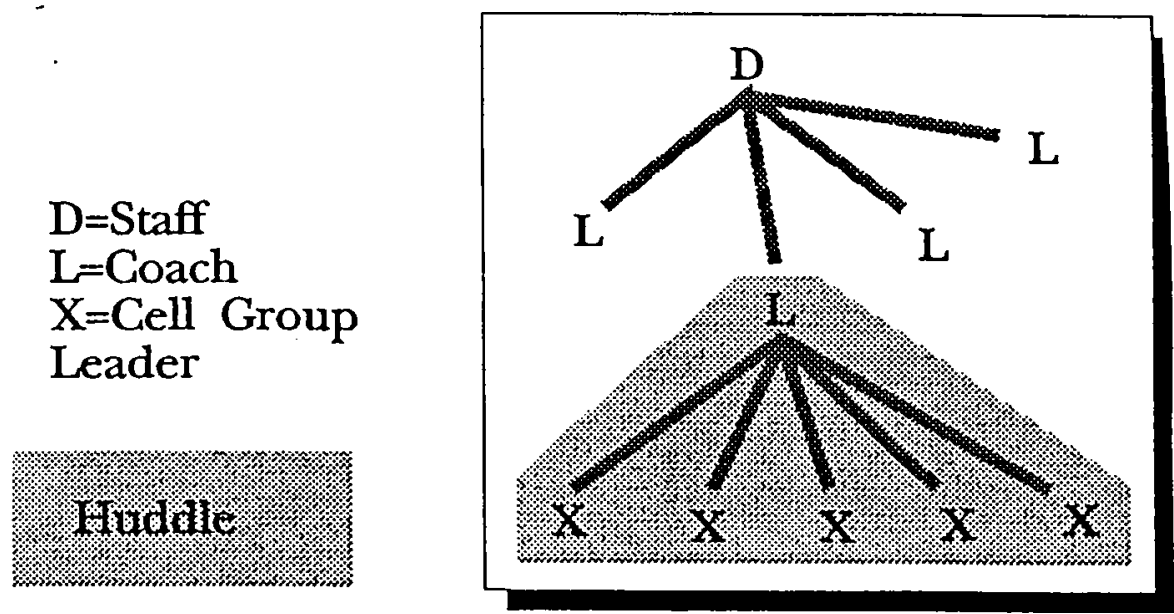

\section{Jethro II, With Apprentices Shown}

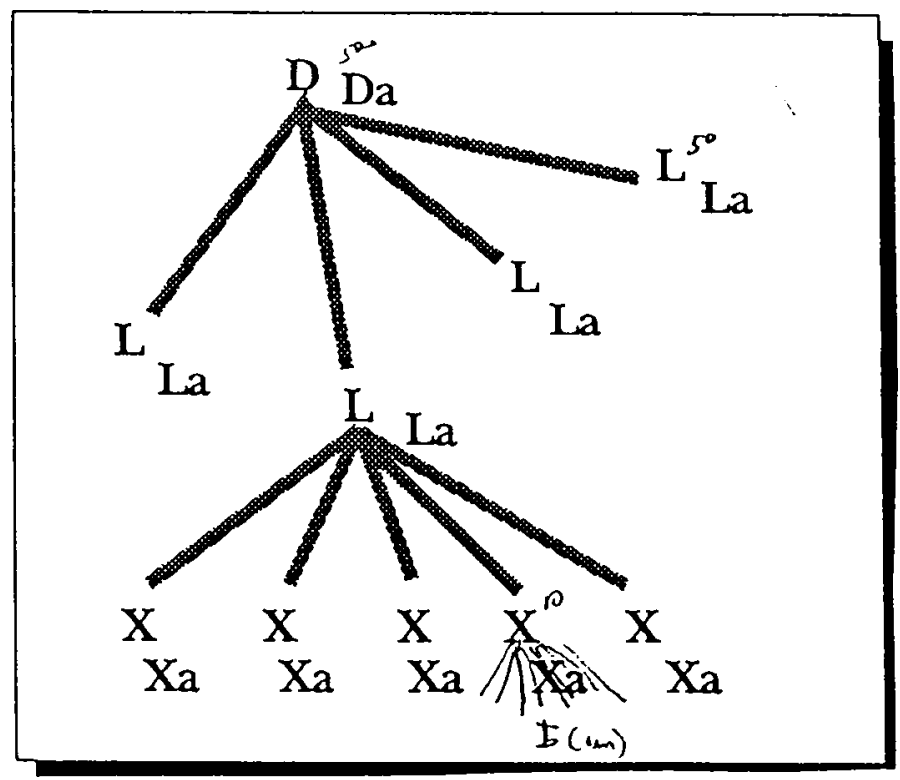

Source: Carl George, Prepare your Church for Future, 67. 
APPENDIX E

THE SIDE DOOR AND THE FRONT DOOR 
Appendix E

The Side Door and the Front Door

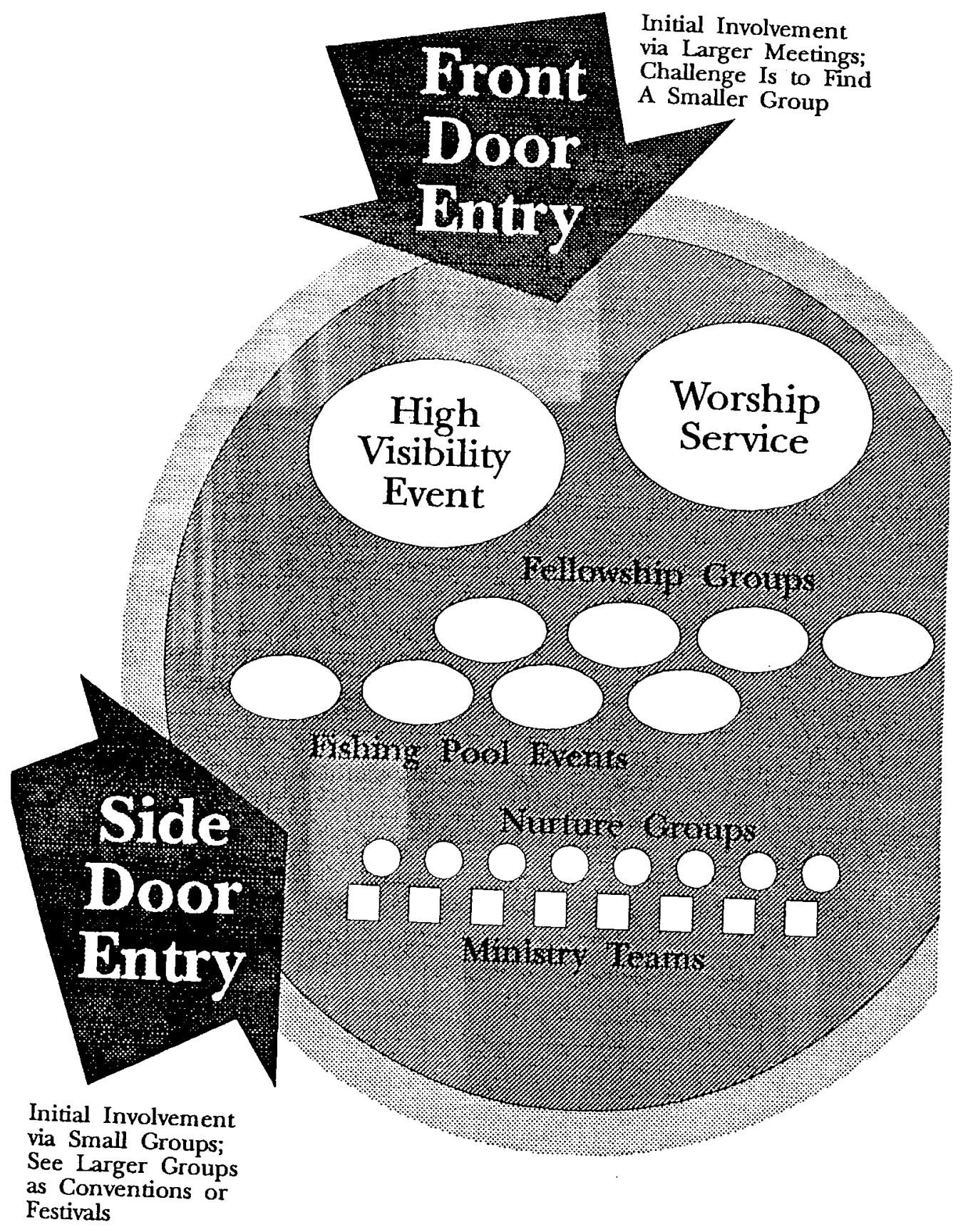

Source: Carl George, Prepare your Church for Future, 56. 


\section{APPENDIX F}

THE PERT SYSTEM 


\section{The Pert System}

The purpose of this appendix is to put the necessary action in the context of planning and evaluating. The model presented for reaching and discipling people should be put into action in a target area, and its outcome should be assessed carefully to see if the mission, objectives, goals, and activities met effectively.

The approach suggested to achieve it is the PERT system. PERT (Program Evaluation and Review Technique) is described by B. J. Jansen as "an control instrument for defining the parts of the job and putting them together in network form."1 According to Dayton and Fraser, one of the advantages of the PERT technique is that "it shows us not only how long it may take to reach a particular goal, but the interrelationship of goals."

Thus we map out a path to the model's implementation through a detailed PERT chart which consists of six networks, or related consecutive activities and events connected to form a logical chain:

Network I: 9 events [activities 1-8] terminating with a final plan.

Network II: 17 events [activities 9- 26] terminating with the pioneer church practicing aggressive evangelism.

Network III: 5 events [activities 27- 31] terminating with the first converts.

Network IV: 4 events [activities 32-36] terminating with the organization of the 297.

'B. J. Jansen, Practical PERT (Washington, DC: America House, 1964), 10-11.

${ }^{2}$ Edward R. Dayton and David A. Fraser, Planning Strategies for World Evangelization, 
new church.

Network V: 7 events [activities 37-42] terminating with the new church conscious of its identity. It contains two subnetworks. Activities 37- 39 involving nurture, and activities 40- 41 involving fellowship. Then there are 10 events [activities 43-45] terminating with the new church taking care of itself with two subnetworks: Activities 4345 involving finances, and activities $46-47$ involving lifestyle. Finally there are 6 events [activities 53-58] terminating with the new church existing for others with two subnetworks: Activities 52- 55 involving evangelism, and activities 56- 58 involving social concern.

Network VI: 3 events [activities 59- 61] terminating with a new mature church able to reproduce itself

Network I: Involving the Planning Period

Activity 1 (goal: event 2): Choose possible target areas for a new church considering geographic and demographic factors as well as the presence of prospects and the presence of a nucleus of believers. ${ }^{1}$

Activity 2 (goal: event 3): Make a detailed demographic survey of the target area. Activity 3 (goal: event 4): Elaborate the initial strategy for the target area.

Activity 4 (goal: event 5): Review discipleship principles and local needs with the Conference staff.

'See Roger McNamara, A Practical Guide to Church Planting (Cleveland, OH: Baptist Mid-Mission, 1985), 37-51. 
Activity 5 (goal: event 6): Discuss ideas and brainstorm activities from each area.

Activity 6 (goal: event 7): Present discipleship principles and local needs to lay leaders from the churches of the proximity of the target area.

Activity 7 (goal: event 8): Involve them in planning and define their role in the process.

Activity 8 (goal: event 9): Elaborate a plan with clear goals, activities, and timetable.

Network II: Involving the Preparatory Period

Activity 9 (goal: event 11): Execute the initial evangelistic strategy in the target area.

Activity 10 (goal: event 10): Promote a caring atmosphere (church preparation). Activity 11 (goal: event 11): Promote a commitment atmosphere (service preparation).

Activity 12 (goal: event 12): Design attractive and contextualized materials; purchase Bibles, felt need resources, and equipments.

Activity 13 (goal: event 13): Print materials, organize kits for every phase of the strategy.

Activity 14 (goal: event 14): Survey possibility to buy, build, or rent appropriate facilities.

Activity 15 (goal: event 15): Prepare a suitable meeting place: painting, pews, legal contract, illumination, etc. 
Activity 16 (goal: event 16): Teach biblical principles of discipleship (Phase 1: discipleship model for seminarians). ${ }^{1}$

Activity 17 (goal: event 17): Prayerfully select members of the church planting team and involve them in phase 2 of the seminarian's discipleship model.

Activity 18 (goal: event 18): Prepare students specifically to achieve discipleship and church planting goals in phase 3 .

Activity 19 (goal: event 19): Teach personal discipleship models for core lay leaders.

Activity 20 (goal: event 20): Provide training in personal evangelism for church member through lay leaders and seminarians.

Activity 21 (goal: event 21): Lay leaders organize and assign each member a job placement and job description.

Activity 22 (goal: event 22): Prepare lay leaders specifically to supervise and achieve discipleship goals.

Activity 23 (goal: event 23): Organize the inreach / outreach activities and the structures of the model (cell, congregation, celebration, and core).

Activity 24 (goal: event 24): Provide relevant information and a plan for finding funds. ${ }^{2}$

Activity 25 (goal: event 25): Solicitation and follow-up.

${ }^{1}$ See chapter 5 .

${ }^{2}$ See Chester L. Tolston, Proven Principles for Finding Funds ( Grand Rapids, MI: Baker Books, 2003) 55-77. 
Network III: Involving the Outreach Period

Activity 26 (goal: event 26): Promote a contagious atmosphere (member preparation) through spiritual motivation.

Activity 27 (goal: event 27): Build awareness and positive attitudes toward Christianity and SD Adventism.

Activity 28 (goal: event 28): Meet physical and social needs of those people being evangelized.

Activity 29 (goal: event 29): Carefully teach the people the basic doctrines of the faith.

Activity 30 (goal: event 30 ): Call those who are responsive for a commitment. Activity 31 (goal: event 31): Take careful note of the spiritual decision process while evangelizing (Engel's Scale).

Network IV: Involving the Inreach Period

Activity 32 (goal: event 33): Gather the prospect people and first converts for mutual edification in cell and congregation structures.

Activity 34 (goal: event 32): Carefully teach the new believers the most controversial doctrines of the faith.

Activity 35 (goal: event 34): Involve new believers in the activities and structures of the levels 4 to 7 of the model.

Activity 36 (goal: event 35): Promote cell and congregational activities to help unite all new believers in the target area. 
Activity 33 (goal: event 35): Teach the new believers that which is the essentials to membership in the local church and proceed to organize the new local church.

\section{Network V: Period of Growth and Organization}

Activity 37 (goal: event 36): Systematically repeat the biblical doctrines and teach spiritual formation to new believers.

Activity 38 (goal: event 37): Involve new believers in the nurture groups of the model (care groups and membership classes).

Activity 39 (goal: event 38): Continually nurture new believers through specific Christian literature.

Activity 40 (goal: event 39): Establish times and places for the assembling of believers.

Activity 41 (goal: event 40): Ensure that each new believer grows in different setting (one on one, triads, small groups, etc.).

Activity 42 (goal: event 41 ): Encourage the members live as a body.

Activity 43 (goal: event 42): Carefully teach the scriptural doctrine of stewardship. Activity 44 (goal: event 43): Regularly remind members of the financial goals of the church.

Activity 45 (goal: event 44 ): Systematically revise the financial goals toward selfsupport.

Activity 46 (goal: event 45 ): Teach new members to practice a biblical lifestyle (time, recreation, health, etc.). 
Activity 47 (goal: event 46): Teach new members God's ideal for a Christian home.

Activity 48 (goal: event 47): Select and equip leaders for administrative functions. Activity 49 (goal: event 48): Provide a job description for each needed task of the church

Activity 50 (goal: event 49): Make certain that leaders are assigned and understand their job.

Activity 51 (goal: event 50):Improve communication in the public worship services.

Activity 52 (goal: event 51): Hold balanced and attractive services.

Activity 53 (goal: event 52): Give training in personal evangelism to members. Activity 54 (goal: event 53): Help members discover and utilize their gifts.

Activity 55 (goal: event: 54): Elaborate and execute plans for concrete steps to evangelize the target area.

Activity 56 (goal: event 55): Familiarize with the population of the target area. Activity 57 (goal: event 56): Observe the social conditions and felt needs of the target community.

Activity 58 (goal: event 57): Make a plan that will mobilize the church to meet social needs of the target area.

Network VI: Period of Reproduction

In fully realizing the goals of PERT events related to the growth and organization 
of the new church (event 35), a new church has also achieved the three main requirements for the church to be mature, able, and motivated to reproduce itself: to be conscious of its identity, to take care of itself, and to exist for others (events $58,59,60$ ). After a period of continued mentor relationship with the evangelist (seminarian), churches in the area, and the denomination (events 61,62 ), the new church is mature and motivated to reproduce itself (event 63).

In conclusion, we present a sequence of charts in PERT system that shows the events and activities above described. For a better understanding of this scheme, we suggest the following key explanatory note

In his book Church Planting for Reproduction, Samuel D. Farcloth gives two definitions that are central to understanding PERT terminology. ${ }^{1}$ First, each numbered box represents a goal or step to be achieved, which is called an event and is related to one another by lines or activities. Second, each set of solid lines indicates a chain or network of activities and events to be planned in order to reach the next major goal. Third, the subgoal these events influence are shown by broken lines. In the broken lines there is no activity but it only indicate a relationship between events so connected.

It is also important to read PERT plan from left to right, beginning in event one and finishing in event 63 with a new mature church and a disciple able to reproduce himself or herself.

'Samuel D. Farcloth, Church Planting for Reproduction (Grand Rapids, MI: Baker Books, House, 1991), 37. 


\section{I- Planning Period: Events 1 -9}

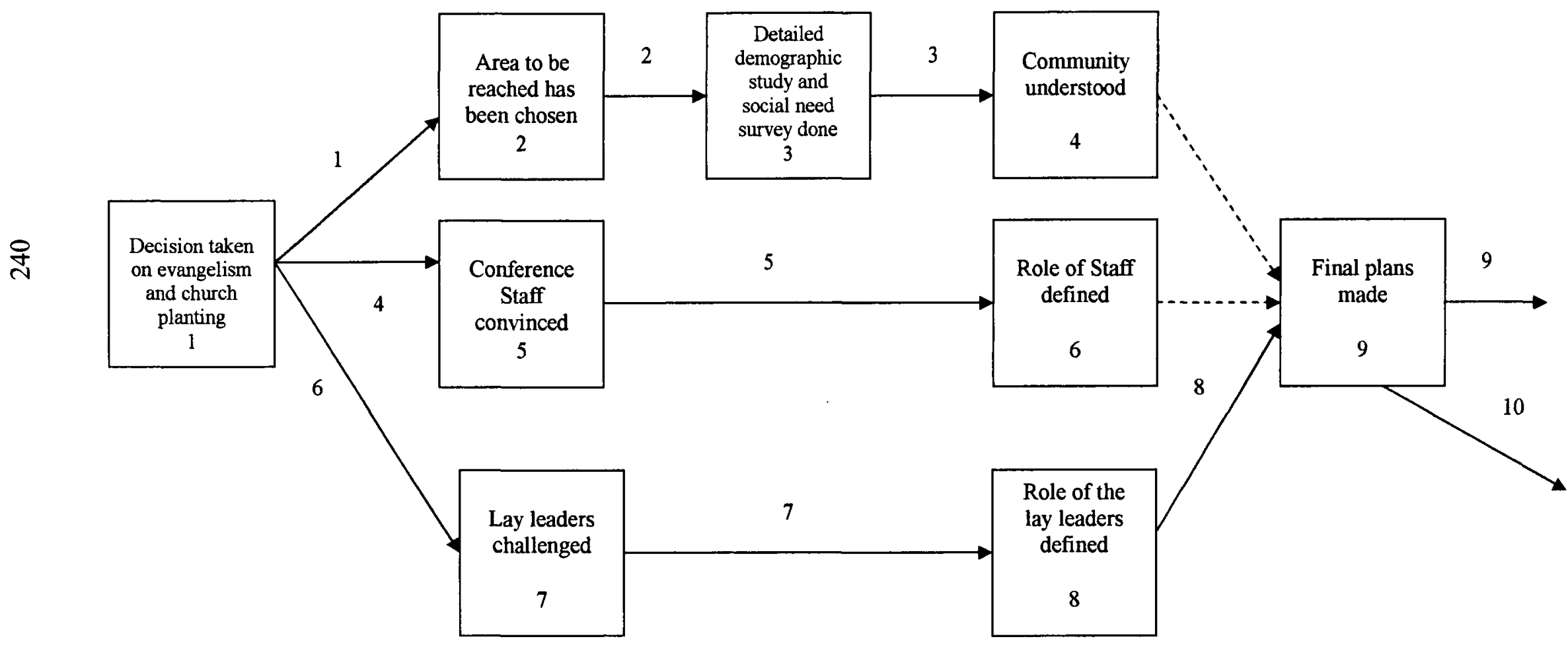




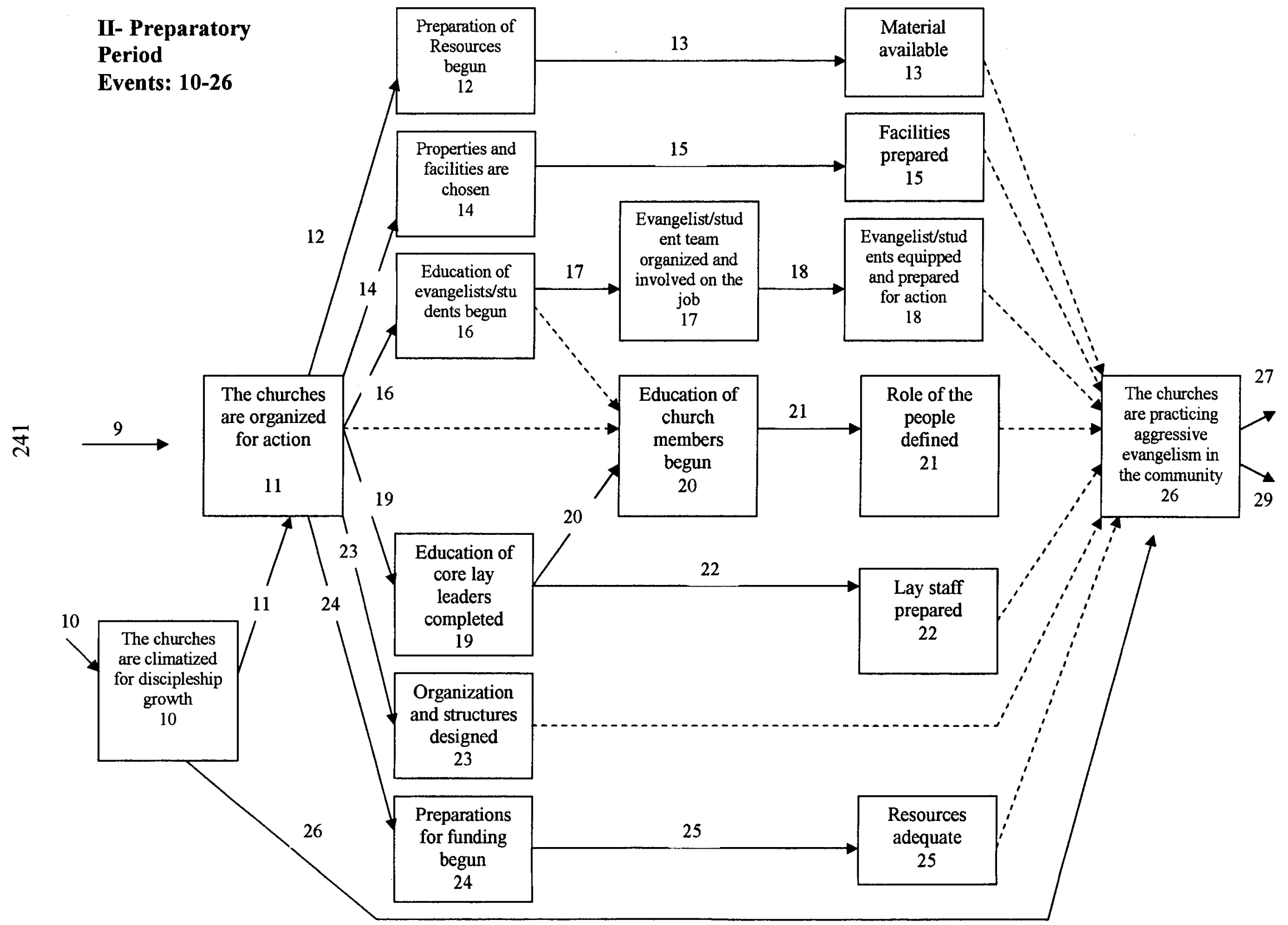




\section{III- Outreach Period: Events 27-31}

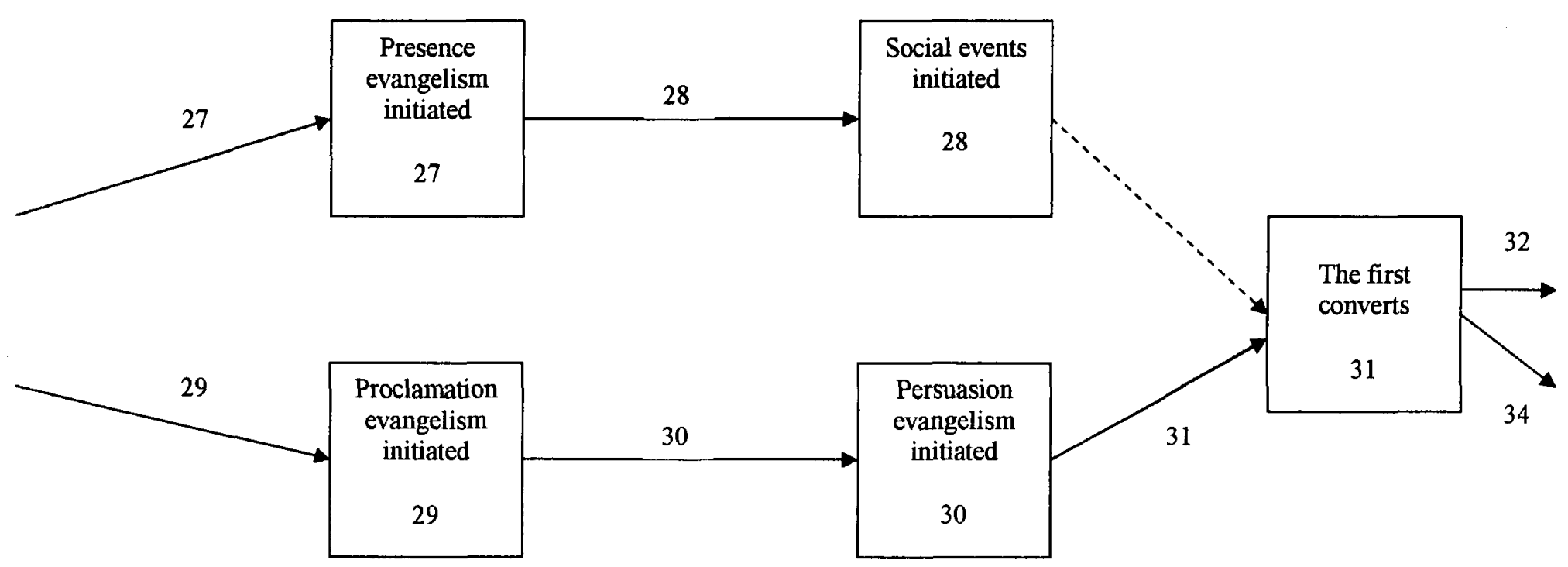


IV- Inreach Period: Events 32-34

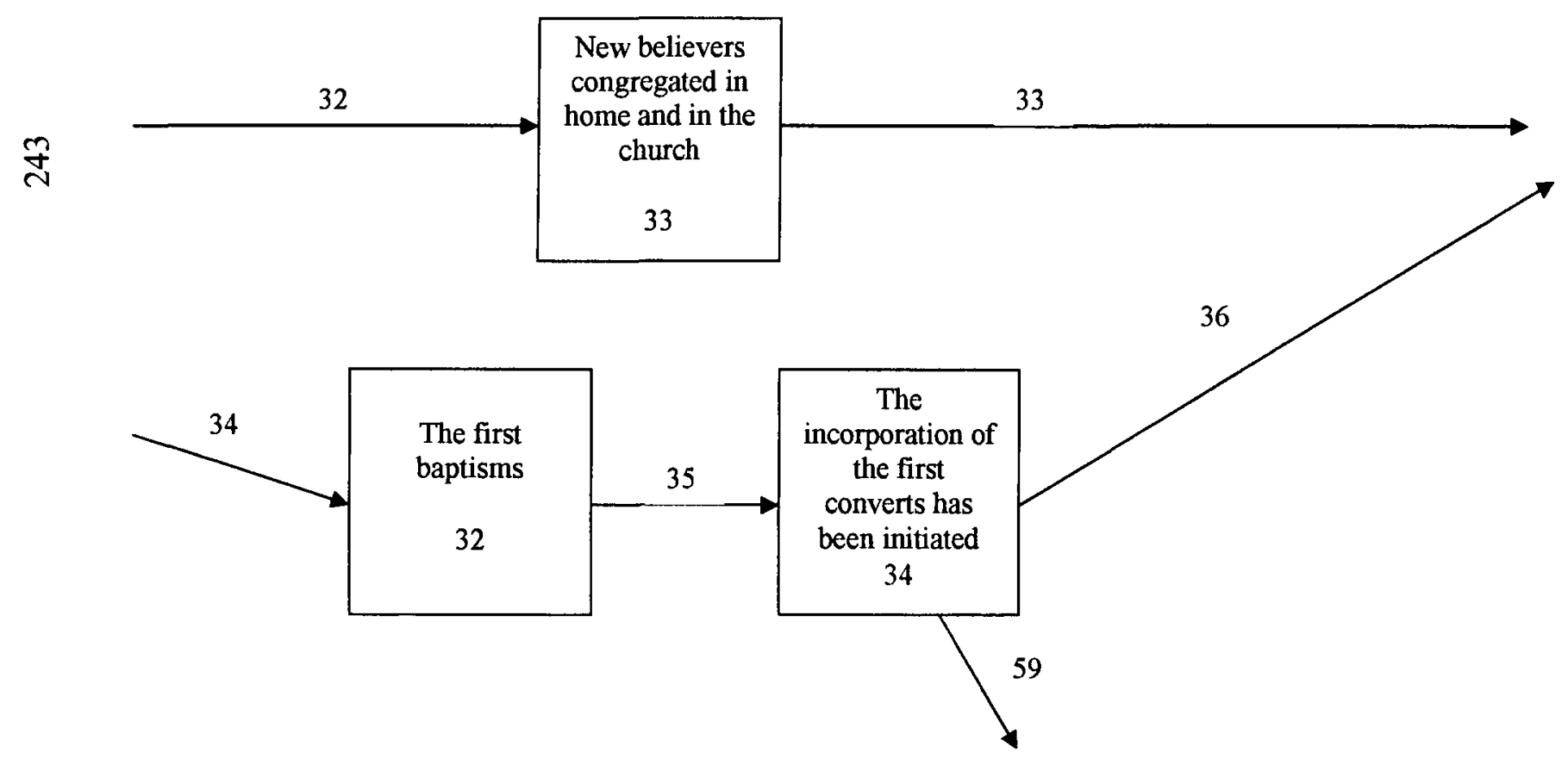




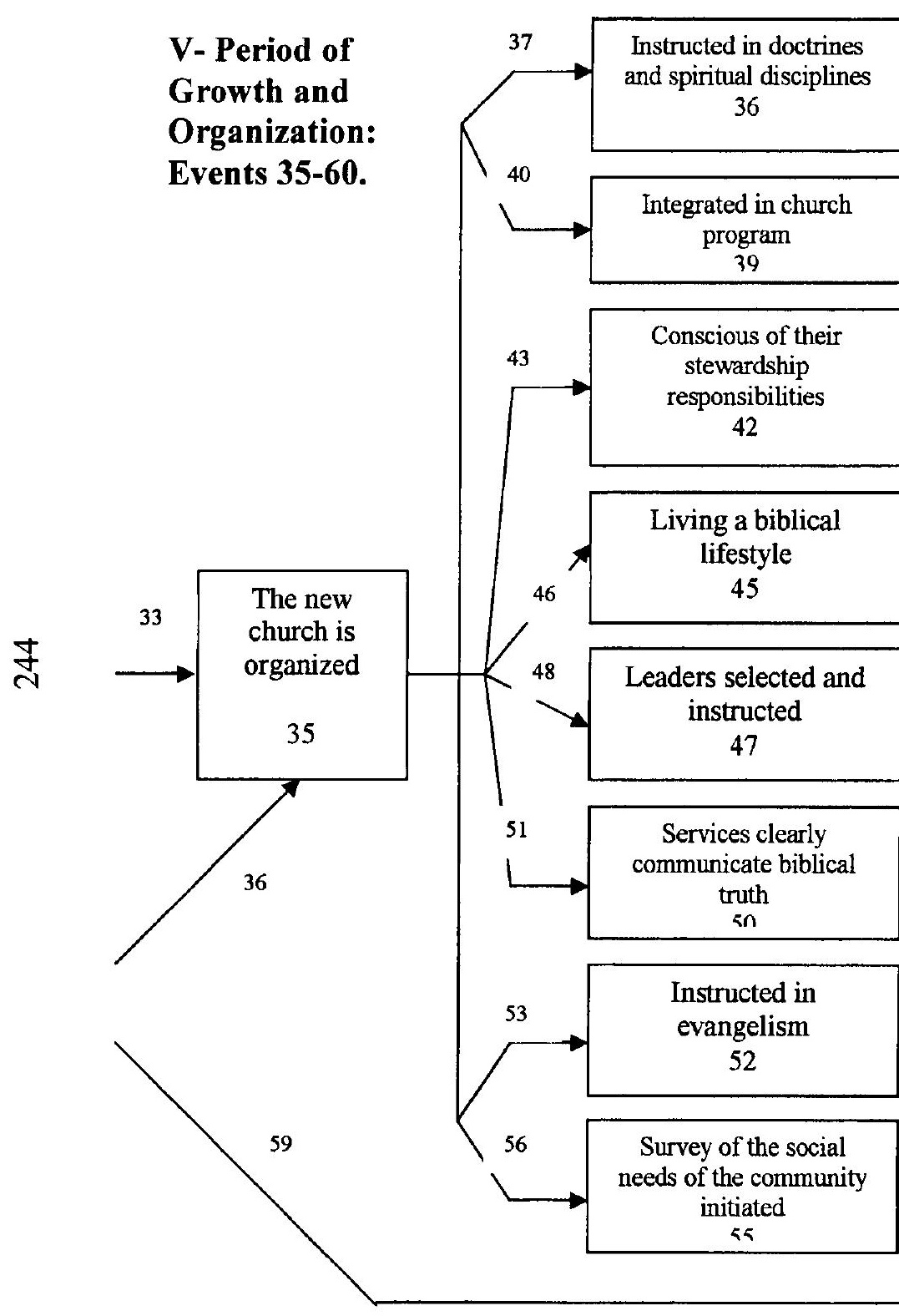


VI- Period of multiplication: Events 61-63

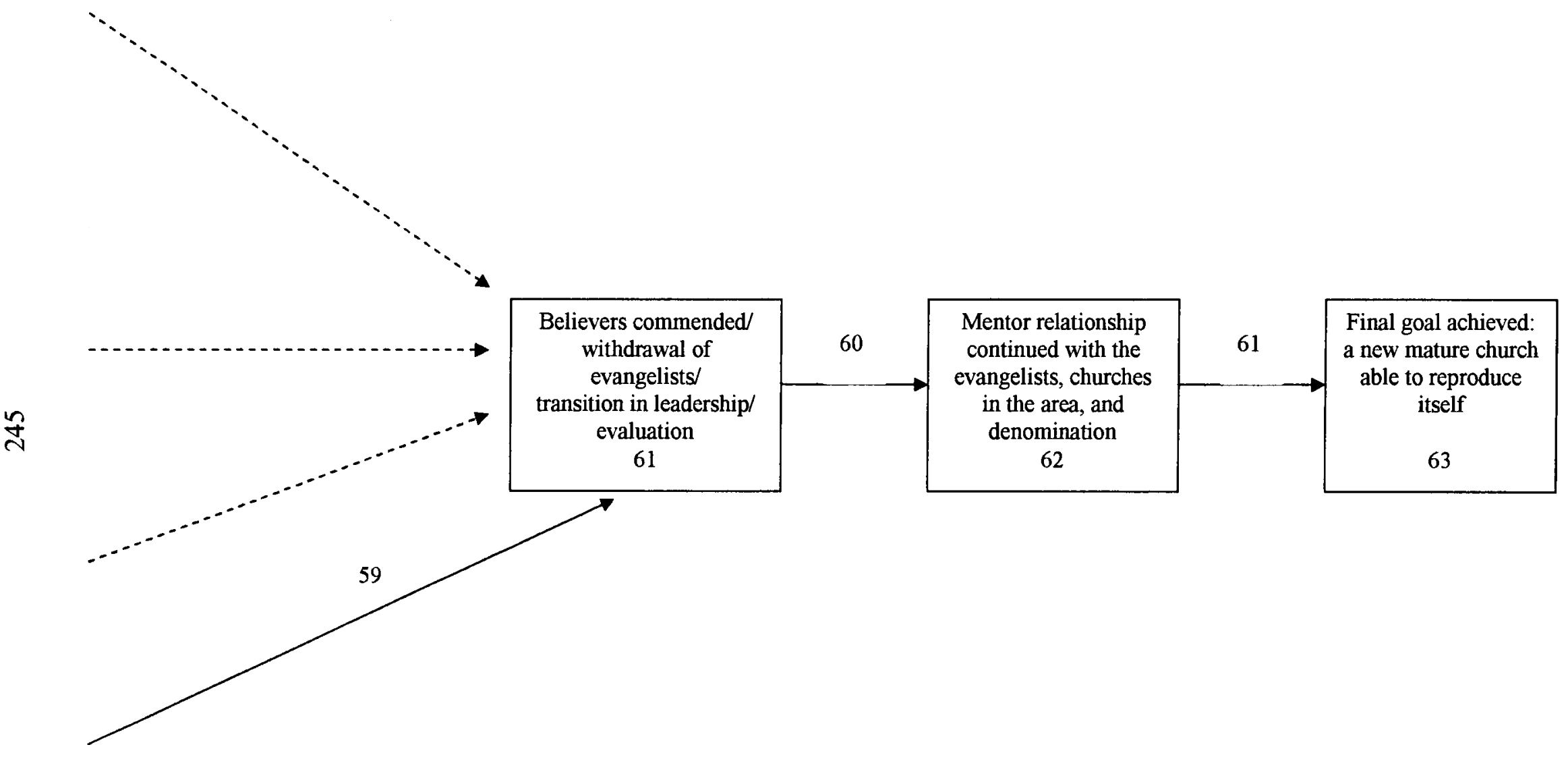




\section{BIBLIOGRAPHY}




\section{BIBLIOGRAPHY}

Aldrich, Joe. Lifestyle Evangelism. Sisters, OR: Multnomah Publishers, 1993.

Allen, Rolland. Missionary Methods: St. Paul's or Ours? Grand Rapids, MI: Wm. B. Eerdmans Publishing Co., 1962.

Arn, Win. "Mass Evangelism: The Bottom Line." In The Pastor 's Church Growth Handbook, ed. W. Arn, 95-109. Pasadena, CA: Church Growth Press, 1979.

Arn, Win, Carroll Nyquist, and Charles Arn. Who Cares about Love? Monrovia, CA: Church Growth Press, 1986.

Arn, Win, and Charles Arn. The Master's Plan for Making Disciples. Grand Rapids, MI: Baker Book House, 1998.

Autrey, G. E. Basic Evangelism. Grand Rapids, MI: Zondervan Publishing House, 1959.

Badcock, Francis J. The Pauline Epistles. New York: MacMillan Company, 1937.

Barna, George. Growing True Disciples. Colorado Springs, CO: WaterBrook Press, 2001.

Baumgartner, Erich W. "Mega Churches and What They Teach Us." In Adventist Mission in the $21^{\text {st }}$ Century, ed. Jon L. Dybdahl, 152. Hagerstown, MD: Review and Herald Publishing Association, 1999.

Beckham, William A. The Second Reformation: Reshaping the Church for the 21st Century. Houston, TX: Touch Publications, 1997.

Bell, Chip R. Managers as Mentors. San Francisco, CA: Barrett-Koehler, 1996.

Beougher, Timothy, and Alvin Reid. Evangelism for a Changing World. Wheaton, IL: Harold Shaw Publishers, 1995.

Biehl, Bobb. Masterplanning: The Complete Guide for Building a Strategic Plan for Your Business, Church, or Organization. Nashville: Broadman and Holman Publishers, 1997.

Bilezikian, Gilbert. Community 101. Grand Rapids, MI: Zondervan Publishing House, 1997. 
Blackaby, Henry, and Claude King. Experiencing God. Nashville, TN: Broadman and Holman Publishers, 1997.

Blast, Robert L. Attracting New Members. Monrovia, CA: Church Growth,1988.

Booth, F. Carlton. "Evangelism in the Home Church." Baker's Dictionary of Practical Theology. Edited by Ralph G. Turnbull. Grand Rapids, MI: Baker Book House, 1967. 1:171.

Borges, Michelson. A Chegada do Adventismo ao Brasil. Tatui, SP: Casa Publicadora Brasileira, 2001.

Brazee, George E. Dynamic Stewardship Strategies: Harnessing Time, Talent, and Treasury for Church Growth. Grand Rapids, MI: Baker Books, 1989.

Breitigam, R. R. The Teacher Sent from God. Mountain View, CA: Pacific Press Publishing Assn., 1960.

Bruce, A. B. The Training of the Twelve. Grand Rapids, MI: Kregel Publications,1971.

Brunner, Frederic Dale. Matthew: A Commentary. Vol. 2. Dallas, TX: Word, 1990.

Burrill, Russell. Recovering an Adventist Approach to the Life and Mission of the Local Church. Fallbrook, CA: Hart Research Center, 1972. . Rekindling a Lost Passion: Recreating a Church Planting Movement. Fallbrook, CA: Hart Research Center, 1993. . Revolution in the Church. Fallbrook, CA: Hart Research Center, 1993.

Cahalan, Kathleen A. Projects That Matter: Successful Planning and Evaluation for Religious Organizations. Bethesda, MD: Alban Institute, 2003.

Carter, Herbert Franklin. "The Church Tomorrow, Principles and Strategies for Growth." D.Min dissertation, Fuller Theological Seminary, 1985.

Chaney, Charles L. Church Planting at the End of the Twentieth Century. Wheaton, IL: Tyndale House Publishers, 1982.

Chaney, Charles L., and Grandville Watson. Evangelism Today and Tomorrow. Nashville, TN: Broadman Press, 1993.

Cladis, George. Leading the Team-Based Church. San Francisco, CA: Jossey-Bass Publishers, 1999.

Cloud, Henry, and John Townsend. How People Grow. Grand Rapids, MI: Zondervan Publishing House, 2001. 
Cobb, Gary. Class Lecture for Empowering New Believers, 2002. Billy Graham School of Evangelism, Kansas City, KS.

Cole, Neil. Cultivating a Life for God. Carol Stream, IL: Church Smart Resources, 1999.

Coleman, Robert. The Masterplan of Evangelism. Grand Rapids, MI: Fleming H. Revell, 1964.

Comiskey, Joel. Home Cell Group Explosion: How Your Small Group Can Grow and Multiply. Houston, TX: Touch Publications, 2002.

Coppedge, Allan. The Biblical Principles of Discipleship. Grand Rapids, MI: Francis Asbury Press, 1989.

Cox, David. Think Big, Think Small Groups. Watford, England: Department of Personal Ministries of the South England Conference of the Seventh-day Adventists, 1998.

Dayton, Edward R., and David A. Fraser. Planning Strategies for World Evangelization. Grand Rapids, MI: Eerdmans Publishing Company, 1990.

Dawn, Marva. Keeping The Sabbath Holy: Ceasing, Resting, Embracing, and Feasting. Grand Rapids, MI: Eerdmans, 1989.

De Andrade, Manoel Correa. Paisagens e Problemas do Brasil. Sao Paulo: Editora Brasilense, 1968.

Delafield, D. A. Ellen G. White in Europe, 1885-1887. Washington, DC: Review and Herald Publishing Assn., 1975.

Dias, Zwinglio M., and Joyce Hill. Brazil: A Gracious People in a Heartless System. New York: Friendship Press, 1997.

Dudley, Roger L., and Des Cummings, Jr. Adventures in Church Growth. Washington, DC: Review and Herald Publishing Association, 1983.

Eims, Leroy. The Lost Art of Disciple Making. Grand Rapids, MI: Zondervan Publishing House, 1978.

Engel, James F., and Wilbert Norton. What's Wrong with the Harvest? A Communication Strategy for the Church and World Evangelism. Grand Rapids, MI: Academic Books, 1975.

Engelkemier, Joel. “A Church That Draws Thousands.” Ministry, May 1991, 14.

Faircloth, Samuel D. Church Planting for Reproduction. Grand Rapids, MI: Baker Book House, 1991.

Fielding, Charles R. "Education for Ministry." Theological Education 3 (1966): 23. 
Foster, Richard J. Celebration of Discipline. New York: Harper Collins Publishers, 1978. .Streams of Living Water. San Francisco, CA: Harper and Row, 1998

Fowler, James. Stages of Faith. San Francisco, CA: Harper and Row, 1984.

Foulkers, Francis. The Letter of Paul to the Ephesians. Tyndale New Testament Commentaries, 10. Grand Rapids, MI: Eerdmans Publishing Company, 1994.

Frazee, Randy. The Connecting Church: Beyond Small Groups to Authentic Community. Grand Rapids, MI: Zondervan, 2001.

Frazee, Randy, and Lyle E. Schaller. The Comeback Congregation: New Life for a Troubled Ministry. Nashville, TN: Abingdon Press, 1995.

Gaertner, Dennis. Acts. The College Press NIV Commentary. Joplin, MO: College Press Publishing, 1993.

General Conference of Seventh-day Adventists. $140^{\text {th }}$ Annual Statistical Report. Washington, DC: Review and Herald Publishing Association, 2002. . Minutes of the Meetings of the General Conference Committee, April 26-May 13, 1929.

.Working Policy of the General Conference of Seventh-day Adventists. Hagerstown, MD: Review and Herald, Publishing Association, 2000.

George, Carl F. Prepare Your Church for the Future. Grand Rapids, MI: Fleming H. Revell, 1992.

Gerber, Vergil. A Manual for Evangelism and Church Growth. South Pasadena, CA: William Carey Library, 1973.

Getz, Gene, and Joe Wall. Effective Church Growth Strategies. Nashville, TN: Word Publishing, 2000.

Gibbs, Eddie. I Believe in Church Growth. London: Hadder and Stoughton, 1992.

Green, Michael. Evangelism in the Early Church. London: Hodder and Stoughton, 1970.

Greenleaf, Floyd. The Seventh-day Adventist Church in Latin America and the Caribbean. Berrien Springs, MI: Andrews University Press, 1992.

Hadaway, C. Kirk. Church Growth Principles: Separating Facts from Fiction. Nashville, TN: Broadman Press, 1991.

Hagberg, Janet, and Robert Guelich. The Critical Journey: Stages in the Life of Faith. Salem, WI: Sheffield Publishing, 1995. 
Hagner, Donald A. Matthew 14-28. Word Biblical Commentary. Dallas, TX: Word Books, 1982.

Halliwell, Leo. Light in the Jungle. Mountain View, CA: Pacific Press Publishing Association, 1972.

Harre, Alan F. Close the Back Door: Ways to Create a Caring Congregational Fellowship. St. Louis, MO: Concordia Publishing House, 1984.

Hay, David M. Colossians. Abingdon New Testament Commentaries. Nashville: Abingdon Press, 2000.

Heck, Joel D. New Member Assimilation: Practical Prevention of Backdoor Loss through Frontdoor Care. St Louis, MO: Concordia Publishing Home, 1984.

Heitzenrater, Richard P. The Elusive Mr. Wesley. Nashville, TN: Abingdon Press, 1984.

Henderson, Michael. John Wesley`s Class Meeting: A Model for Making Disciples. Nappanee, IN: Evangelical Publishing House, 1997.

Hendrichsen, Walter. Disciples Are Made Not Born. Colorado Springs, CO: Chariot Victor Publishing, 1974.

Hendriksen, William. Exposition of the Gospel according to Matthew. New Testament Commentary. Grand Rapids, MI: Baker Book House, 1973.

Hendriksen, William, and Simon J. Kistemaker. Exposition of Thessalonians, the Pastorals and Hebrews. New Testament Commentary. Grand Rapids, MI: Baker Books, 1995.

Hesselgrave, David J. Planting Churches Cross-Culturally. Grand Rapids, MI: Baker Book House, 1980.

Hettinga, John. Follow Me: Experience the Loving Leadership of Jesus. Colorado Springs, CO: NavPress, 1996.

Hiebert, Arthur. "Biblical Principles for Church Growth: Strategies for the Contemporary Church." D.Min. dissertation, Fuller Theological Seminary, 1986.

Hornecker, Ronald. "Choosing a Ministry Placement and Field Supervision." In Experiencing Ministry Supervision: A Field-Based Approach, ed. William T. Pyle and Mary Alice Seals, 24, 25. Nashville, TN: Broadman and Holman Publishers, 1995.

Hull, Bill. Building High Commitment in a Low Commitment World. Grand Rapids, MI:

Fleming H. Revell, 1995. . The Disciple Making Church. Grand Rapids, MI: Fleming Revell, 1990. 
. The Disciple Making Pastor. Old Tappan, NJ: Fleming H. Revell, 1980.

. New Century Disciplemaking. Grand Rapids, MI: Fleming Revell, 1984.

Hunter, Kent R. Foundations for Church Growth: Biblical Basics for the Local Church. Corunna, IN: Church Growth Center, 1994.

Hunter I, George I. Theological Field Education. Boston, MA: Boston Theological Institute, 1977.

Hunter, George G., III. To Spread the Power: Church Growth in the Wesleyan Spirit. Nashville, TN: Abingdom Press, 1987.

Huston, Sterling W. Crusade Evangelism and the Local Church. Minneapolis, MN: World Wide Publications, 1996.

Hybels, Bill, and Lynne Hybels. Rediscovering Church: The Story and Vision of Willow Creek Community Church. Grand Rapids, MI: Zondervan Publishing House, 1995.

Hybels, Bill, and Mark Mittelberg. Becoming a Contagious Christian. Grand Rapids, MI: Zondervan Publishing House, 1994.

Icenogle, Gareth. Biblical Foundations for Small Group Ministry: An Integrative Approach. Downers Grove, IL: InterVarsity Press, 1998.

Jenson, Ron, and Jim Stevens. Dynamics of Church Growth. Grand Rapids, MI: Baker Book House, 1981.

Joslin, Roy. Urban Harvest: Biblical Perspectives on Christian Mission in the Inner Cities. Welwyn, England: Evangelical Press, 1982.

Keener, Craig S. Matthew. The IVP New Testament Commentary. Downers Grove, IL: InterVarsity Press, 1997.

Kistemaker, Simon J. Exposition of the Acts of the Apostles. New Testament Commentary. Grand Rapids, MI: Baker Book House, 1990.

Knowles, Malcolm. The Modern Practice of Adult Education: Andragogy versus Pedagogy. Chicago, IL: Follett Publishing Co., 1970.

Library of Congress, Federal Research Division. Brazil: A Country Study. Edited by Rex A. Hudson. Washington, DC: US Government Printing Office, 1998.

Logan, Robert E. Beyond Church Growth. Tarrytown, NY: F. H. Revell, 1980.

Logan, Robert E. Mobilizing for Compassion: Moving People into Ministry. Grand Rapids, MI: Fleming H. Revell, 1994. 
Logan, Robert L., and Sherilyn Carlton. Coaching 101: Discover the Power of Coaching. St Charles, IL: ChurchSmart Resources, 2003.

MacArthur, John. Ashamed of the Gospel: When the Church Becomes Like the World. Wheaton, IL: Crossing Books, 1993.

MacArthur, John. Ephesians. The MacArthur New Testament Commentary. Chicago, IL: Moody Press, 1986.

. Acts 1-12. The MacArthur New Testament Commentary. Chicago, IL: Moody Press, 1954.

Macchia, Steven. Becoming a Healthy Church. Grand Rapids, MI: Baker Books, 1999.

Malphurs, Aubrey. Strategy 2000: Churches Making Disciples for the Next Millennium. Grand Rapids, MI: Kregel Publications, 1996.

Pouring New Wine into Old Skins: How to Change a Church without Destroying It. Grand Rapids, MI: Baker Books, 1993.

Mandlin, Michael G., and Edward Gilbreath. "Selling Out the House of God?" Christianity Today, July 1994, 21-23.

Marshall, I. Howard. The Acts of the Apostles: An Introduction and Commentary. Tyndale New Testament Commentaries. Grand Rapids, MI: Eerdmans Publishing Company, 1980.

Martin, Carlos G. Turning the World Upside Down. Nampa, ID: Pacific Press Publishing Assn., 2000.

May, F. J. "The Book of Acts and Church Growth." D.Min. dissertation, Fuller Theological Seminary, 1989.

McCarty, Doran. The Supervision of Ministry Students. Atlanta, GA: Home Mission Board, 1979.

McGavran, Donald. Understanding Church Growth. Grand Rapids, MI: W. B. Eerdmans, 1990.

McGavran, Donald, and George G. Hunter III. Church Growth: Strategies That Work. Edited by L. E. Schaller. Nashville, TN: Parthenon Press, 1980.

McGavran, Donald, and Win C. Arn. Ten Steps for Church Growth. San Francisco, CA: Harper and Row Publishers, 1997.

McIntosh, Gary. Biblical Church Growth: How You Can Work with God to Build a Faithful Church. Grand Rapids, MI: Baker Books, 2003. 
McNamara, Roger. A Practical Guide to Church Planting. Cleveland, OH: Baptist MidMissions, 1983.

Mead, Loren B. Five Challenges for the Once and Future Church. New York, NY: Alban Institute, 1996.

Miller, D. Mathetes. The New International Dictionary of New Testament Theology. Edited by Colin Brown. Grand Rapids, MI: Regency Reference Library, 1986. $1: 484$.

Mittelberg, Mark. Building a Contagious Church: Revolutionizing the Way We View and Do Evangelism. Grand Rapids, MI: Zondervan Publishing House, 2000.

Moorhead, Bob. The Growth Factor. Joplin, MO: College Press Publishing Company, 1988.

Mulholland, Robert, Jr. Invitation to a Journey: A Road Map for Spiritual Formation. Downers Grove, IL: InterVarsity Press, 1993.

Nepper-Christensen, P. "Matheteuo," Exegetical Dictionary of the New Testament. Edited by Horst Baltz and Gerhard Schneider, 2:372. Grand Rapids, MI: Eerdmans Publishing Company, 1990.

Norton, Ricardo. Class Lecture for Strategies for Church Growth, 2002. Andrews University, Berrien Springs, MI.

Ogden, Greg. Discipleship Essentials: A Guide to Building to Life in Christ. Downers Grove, IL: InterVarsity Press, 1998.

. Class Lecture for Growing a Disciple Making Congregation, 2003. Fuller Theological Seminary. Pasadena, CA. . Transforming Discipleship: Making Disciples a Few at a Time. Downers Grove, IL: InterVarsity Press, 2003.

Ogne, Steven L., and Thomas P. Nebel. Empowering Leaders Through Coaching: A SelfStudy Kit for Those Who Mentor Volunteer Leaders, Pastors, and Church Planters. Nashville, TN: ChurchSmart Resources, 1995.

Oliver, Barry D. "Can or Should Seventh-day Adventist Belief Be Adapted to Culture?" In Adventist Mission in the 21st Century: The Joys and Challenges of Presenting Jesus to a Diverse World, ed. Jon Dybdahl, 72-79. Hagerstown, MD: Review and Herald Publishing Assoc., 1999.

Osborne, Larry. "Equipping The Saints to Lead." In Growing Your Church through Training and Motivation, ed. Marshall Shelley, 97. Minneapolis, MN: Bethany House Publishers, 1997. 
Oswald, Roy M., and Speed B. Leas. The Inviting Church: A Study of a New Member Assimilation. New York, NY: Alban Institute, 1987.

Otto, Stan. The Joy of Discipling. Grand Rapids, MI: Zondervan Publishing House, 1989.

Page, Joseph A. The Brazilians. Menlo Park, CA: Addison-Wesley Publishing Company, 1995.

Patten, Mildred L. Understanding Research Methods: An Overview of the Essentials. Glendale, Ca: Pyrczak Publishing, 2004.

Patzia, Arthur G. Colossians, Ephesians, Philemon. Good News Commentary. San Francisco: Harper and Row, 1984.

Peace, Richard. Small Group Evangelism: A Training Program for Reaching Out with the Gospel. Downers Grove, IL: InterVarsity Press, 1985.

Peel, William Carr, and Walt Larimore. Going Public with Your Faith: Becoming a Spiritual Influence at Work. Grand Rapids, MI: Zondervan, 2003.

Peskett, Howard, and Vinoth Ramachandra. The Message of Mission: The Glory of Christ in All Time and Space. Downers Grove, IL: InterVarsity Press, 2003.

Peters, George W. A Theology of Church Growth. Grand Rapids, MI: Zondervan Publishing House, 1981.

Pointer, Roy. How Do Churches Grow? A Guide to the Growth of Your Church. London: MARC Europe, 1987.

Pritchard, G. A. Willow Creek Seeker Services: Evaluating a New Way of Doing Church. Grand Rapids, MI: Baker Books, 1996.

Pudney, John. John Wesley and His World. New York: Charles Scribner's Sons, 1978.

Rainer, Thom. Effective Evangelistic Churches: Successful Churches Reveal What Works and What Doesn't. Nashville, TN: Broadman and Holman Publishers, 1996.

Rauff, Edward A. Why People Join the Church: An Exploratory Study. New York: Pilgrim Press, 1979.

Reid, Alvin. Introduction to Evangelism. Nashville, TN: Broadman and Holman Publishers, 1980.

Rengstorf, K. H. "The Disciples of Jesus." Theological Dictionary of the New Testament. Grand Rapids, MI: Eerdmans, 1964-1976. 1: 560.

Rogers, Cleon. "The Great Commission." Bibliotheca Sacra 130 (July 1973): 258-67. 
Sahlin, Monte. Adventist Congregations Today: New Evidence for Equipping Healthy Churches. Lincoln, NE: Center for Creative Ministry, 2003. . Sharing Our Faith with Friends without Losing Either. Washington, DC: Review and Herald Publishing Association, 1990.

Schaller, Lyle E. Assimilating New Members. Creative Leadership Series. Nashville, TN: Parthenon Press, 1978. . Create Your Own Future! Nashville, TN: Abingdon Press, 1991.

Shenk, David W. and Ervin R. Stutzman. Creating Communities of the Kingdom: New Testament Models of Church Planting. Scottdale, PA: Herald Press, 1984.

Schmidt, Eduard E., Course Lecture for Equipping and Motivating for Ministry, 2003. Andrews University, Berrien Springs, MI.

Schwarz, Christian. Natural Church Development: A Guide to Eight Essential Qualities of Healthy Churches. Carol Stream, IL: Church Smart Resources, 1996.

Sheldon, Charles. In His Steps. Smithmark, NY: NavPress, 1992.

Shenk, David W., and Ervin R. Stutzman. Creating Communities of the Kingdom: New Testament Models of Church Planting. Scottdale, PA: Herald Press, 1988.

Seventh-day Adventist Bible Commentary. Edited by Francis D. Nichol. Washington, DC: Review and Herald Publishing Association, 1976-80.

Seventh-day Adventist Yearbook. Washington, DC: Review and Herald Publishing Association, 2001.

Shaw, Mark. 10 Great Ideas from Church History: A Decision-Maker's Guide to Shaping Your Church. Downers Grove, IL: InterVarsity Press, 1990.

Simon, John S. John Wesley: The Last Phase. London: Epworth Press, 1934.

Snyder, Howard A. The Radical Wesley: Patterns for Church Renewal. Downers Grove, IL: InterVarsity Press, 1980.

Stanley, Paul D., and Clinton J. Robert. Connecting: The Mentoring Relationships You Need to Succeed in Life. Colorado Springs, CO: NavPress, 1992.

Stark, Rodney. The Rise of Christianity. San Francisco, CA: Harper Collins,1997.

Steinbron, Melvin. The Lay-Driven Church. Ventura, CA: Regal Books, 1997.

Strobel, Lee. Inside the Mind of Unchurched Harry and Mary: How to Reach Friends and Family Who Avoid the Church and God. Grand Rapids, MI: Zondervan Publishing House, 1993. 
Tangeman, Gary E. The Disciple Making Church in the 21 Century. Fort Washington, PA: Christian Literature Crusade, 1996.

Tannehill, Robert C. Luke. Abingdon New Testament Commentaries. Nashville, Abingdon Press, 1996.

Taylor, Clyde W., and Wade T. Coggins. Mobilization for Saturation Evangelism. Wheaton, IL: Evangelical Missions, 1969.

Tolston, Chester L. Proven Principles for Finding Funds. Grand Rapids, MI: Baker Books, 2003.

Towns, Elmer L., John N. Vaughan, and David J. Seifert. The Complete Book of Church Growth. Wheaton, IL: Tyndale House Publishers, 1981.

Viera Rossano, Juan Carlos. "Patterns of Church Growth Within the Seventh-day Adventist Church in River Platte Republics." M.A. thesis, Fuller Theological Seminary, 1988.

Wagner, C. Peter. Church Planting for a Greater Harvest. Ventura, CA: Regal Books, 1990.

. Frontiers of Missionary Service. Chicago: Moody Press, 1971.

. Leading Your Church to Growth. Ventura, CA: Regal Books, 1984.

. Strategies for Church Growth. Ventura, CA: Regal Books, 1987.

. Your Church Can Be Healthy. Nashville, TN: Parthenon Press, 1979.

. Your Church Can Grow. Ventura, CA: Regal Books, 1976.

Warren, Rick. "New Churches for a New Generation: Church Planting to Reach Baby Boomers. A Casa Study: The Saddleback Valley Community Church.” D.Min. dissertation, Fuller Theological Seminary, 1997.

. The Purpose Driven Church: Church Growth Without Compromising Your Message and Mission. Grand Rapids, MI: Zondervan Publishing House, 1995.

. "The Purpose Driven Church: A Contemporary Approach to Church Growth." In Evangelism for a Changing World, ed. Timothy Beougher and Alvin Reid, 23. Wheaton, IL: Harold Shaw Publishers, 1995.

Watson, David Lowes. Called and Committed: World Changing Discipleship. Wheaton, IL: Harold Shaw Publishers, 1982.

. The Early Methodist Class Meeting: Its Origins and Significance. Nashville, TN: Discipleship Resources, 1987. 
Wilkins, Michael. Following the Master: A Biblical Theology of Discipleship. Grand Rapids, MI: Zondervan Publishing House, 1992.

Wilson, J. Christy. Ministers in Training: A Review of Field Work Procedures in Theological Education. Princeton, NJ: Princeton Theological Seminary, 1957.

Willard, Dallas. The Divine Conspiracy: Rediscovering Our Hidden Life in God. San Francisco, CA: Harper, 1998.

. Renovation of the Heart. Colorado Springs, CO: NavPress, 2002.

.The Spirit of the Disciplines: Understanding How God Changes Lives. San Francisco, CA: Harper and Row, 1988.

Williams, David J. Acts. New International Biblical Commentary, 5. Peabody, MA: Hendrickson Publishers, 1990.

.1 and 2 Thessalonians. New International Biblical Commentary, 12. Peabody, MA: Hendrickson Publishers, 1994.

Winter, Ralph D. "The Two Structures of God's Redemptive Mission." In Perspectives on the World Christian Movement: A Reader, ed. Ralph D. Winter and Steven C. Hawthorne, 178-190. Pasadena, CA: William Carey Library, 1981.

Webber, Robert. Journey to Jesus: The Worship, Evangelism, and Nurture Mission of the Church. Nashville, TN: Abingdon Press, 2001.

Westphal, Frank. Pioneering the Neglected Continent. Nashville, TN: Southern Publishing Association, 1927.

White, Ellen G. Acts of the Apostles. Boise, ID: Pacific Press Publishing Association, 1989.

. The Adventist Home. Washington, DC: Review and Herald Publishing Assn., 1980.

. Child Guidance. Hagerstown, MD: Review and Herald Publishing Association, 2000.

. Christian Service. Washington, DC: Review and Herald Publishing Association, 1983.

White, Ellen G. Counsels on Health. Mountain View, CA: Pacific Press Publishing Association, 1951.

. Counsels to Parents, Teachers, and Students: Pacific Press Publishing Association, 1943. 
. Counsels on Stewardship. Washington, DC: Review and Herald Publishing Association, 1940.

. The Desire of Ages. Mountain View, CA: Pacific Press Publishing Assn., 1940.

. Education. Mountain View, CA: Pacific Press Publishing Association, 1943.

Evangelism. Washington, DC: Review and Herald Publishing Association, 1974.

. Fundamentals of Christian Education. Nashville, TN: Southern Publishing Association, 1980.

. God's Amazing Grace. Washington, DC: Review and Herald Publishing Association, 1973.

. Gospel Works. Washington, DC: Review and Herald Publishing Association, 1946.

. MS 29, 1887. Ellen G. White Research Center, Andrews University, Berrien Springs, MI.

. MS 83, 1893. Ellen G. White Research Center, Andrews University, Berrien Springs, MI.

. Medical Ministry. Mountain View, CA: Pacific Press Publishing Association, 1963.

. Ministry of Healing. Mountain View, CA: Pacific Press Publishing Association, 1942.

. Patriarchs and Prophets. Mountain View, CA: Pacific Press Publishing Association, 1978. 1956.

. Steps to Christ. Mountain View, CA: Pacific Press Publishing Association,

Temperance. Mountain View, CA: Pacific Press Publishing Association, 1949. 1948 .

White, Ellen G. Welfare Ministry. Washington, DC: Review and Herald Publishing Association, 1946.

White, James Emery. Rethinking the Church. Grand Rapids, MI: Baker Books, 1997.

Whitmore, David. Coaching for Performance. London: Nicholas Brealey Publishing, 1996. 
Wilson, J. Christy. Ministers in Training: A Review of Field Work Procedures in Theological Education. Princeton, NJ: Princeton Theological Seminary, 1957.

Wood, Arthur Skenvington. The Burning Heart: John Wesley, Evangelist. Grand Rapids, MI: Eerdmans Publishing Company, 1967.

Worcester, Donald E. Brazil: From Colony to World Power. New York: Charles Scribner's Sons, 1973.

Van Engen, Charles. God's Missionary People. Grand Rapids, MI: Baker Book House, 1991.

Yount, William R. A Christian Teacher's Introduction to Educational Psychology: Created to Learn. Nashville, TN: Broadman and Holman Publishers, 1996. 


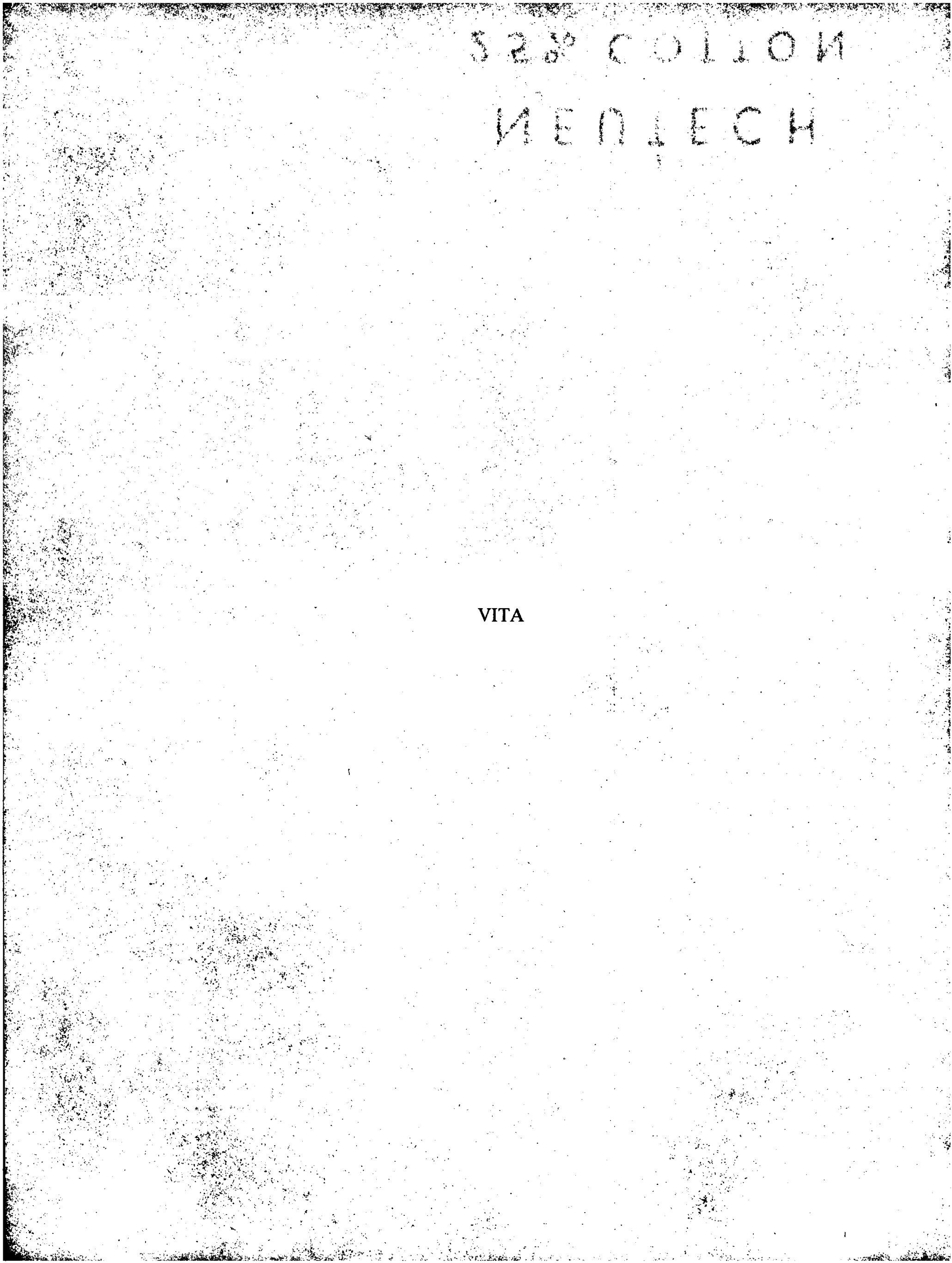




\author{
Emilio Abdala Dutra \\ Date of Birth: June 16, 1963 \\ Country of Origin: Brazil \\ Family: Gina (wife), Samuel, and Sammila \\ EDUCATION: \\ 1985 Bachelor of Theology, Unasp, Sao Paulo, Brazil \\ 2000 Master of Religion, Unasp, Sao Paulo, Brazil \\ 2005 Doctor in Ministry, Andrews University, Berrien Springs, MI
}

PROFESSIONAL EXPERIENCE

1986-1998 Pastor, Minas Gerais Conference in Brazil

1989-1995 Evangelist, Minas Gerais Conference in Brazil

1995-2005 Seminary professor, Northeast Brazil College in Brazil 